\title{
Catalytic Enantioselective Conversion of Epoxides to Thiiranes
}

\author{
Saihu Liao, Markus Leutzsch, Mattia Riccardo Monaco, and Benjamin List \\ Max-Planck-Institut für Kohlenforschung, Kaiser-Wilhelm-Platz 1, D-45470 Mülheim an der \\ Ruhr, Germany \\ list@mpi-muelheim.mpg.de
}

\section{Supplementary Information}

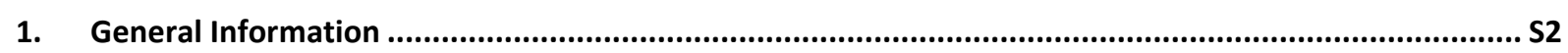

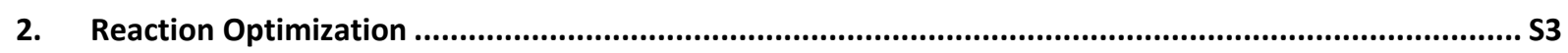

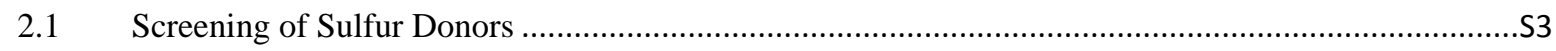

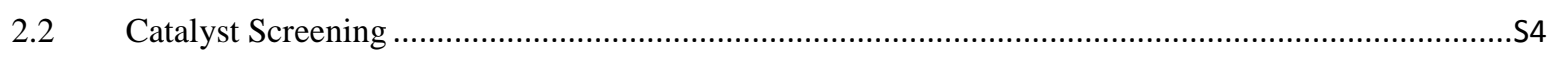

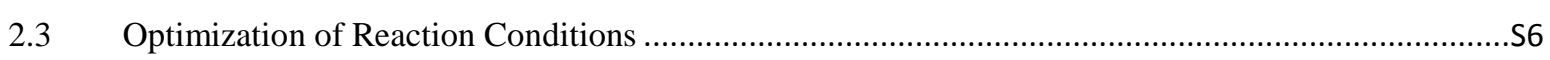

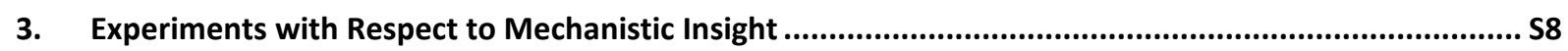

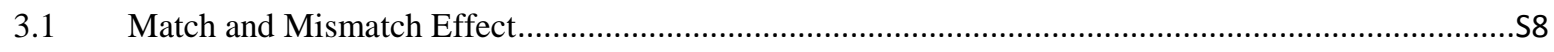

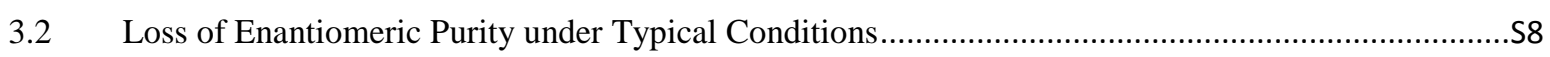

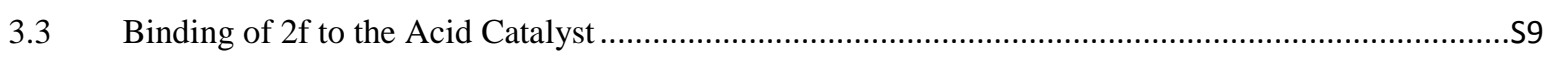

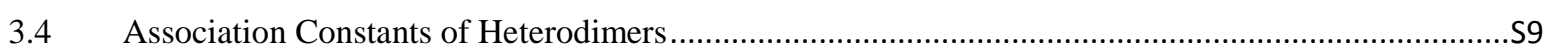

$3.5 \quad$ Reaction Monitoring by ${ }^{1} \mathrm{H}$ NMR Spectroscopy ………............................................................ 16

3.6 NMR Characterization of Reaction Intermediates ...................................................................... S18

3.7 Interconversion and Equilibrium Between the Reaction Intermediates ..........................................S31

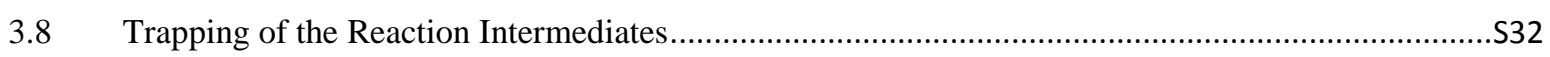

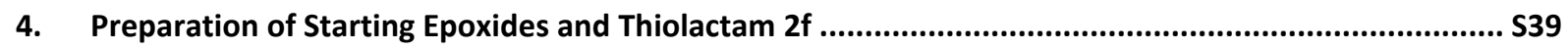

5. Catalytic Enantioselective Conversion of Epoxides to Thiiranes ...................................................... 539

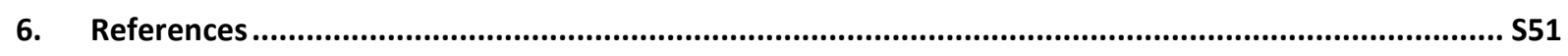

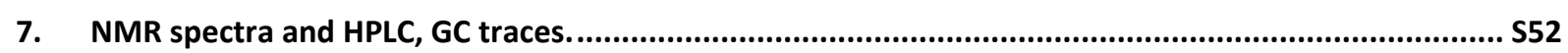




\section{General Information}

Unless otherwise stated, all reagents were purchased from commercial suppliers and used without further purification. All solvents used in the reactions were distilled from appropriate drying agents prior to use. Reactions were monitored by thin layer chromatography on silica gel pre-coated plastic sheets $(0.2 \mathrm{~mm}$, Macherey-Nagel). Visualization was accomplished by irradiation with UV light at $254 \mathrm{~nm}$ and/or phosphomolybdic acid (PMA) stain (PMA $20 \mathrm{~g}$, $250 \mathrm{~mL}$ EtOH). Column chromatography was performed on Merck silica gel (60, particle size 0.040-0.063 mm). Proton and carbon NMR spectra were recorded on Bruker AV-300 or Bruker AV-500 spectrometer in deuterated solvent. Proton chemical shifts are reported in ppm $(\delta)$ relative to tetramethylsilane (TMS) with the solvent resonance employed as the internal standard $\left(\mathrm{CDCl}_{3} \delta 7.26, \mathrm{CD}_{2} \mathrm{Cl}_{2} \delta 5.32\right)$. Data are reported as follows: chemical shift, multiplicity $(\mathrm{s}=$ singlet, $\mathrm{d}=$ doublet, $\mathrm{t}=$ triplet, $\mathrm{q}=$ quartet, $\mathrm{m}=$ multiplet, $\mathrm{br}=$ broad, $\mathrm{cm}=$ centered multiplet), coupling constants $(\mathrm{Hz})$ and integration. ${ }^{13} \mathrm{C}$ chemical shifts are reported in ppm from tetramethylsilane (TMS) with the solvent resonance as the internal standard $\left(\mathrm{CDCl}_{3} \delta 77.23, \mathrm{CD}_{2} \mathrm{Cl}_{2} \delta 53.8\right)$. High resolution mass spectra were determined on a Bruker APEX III FTMS (7T magnet). Optical rotations were determined with Autopol IV polarimeter (Rudolph Research Analytical) at $589 \mathrm{~nm}$ and $25{ }^{\circ} \mathrm{C}$. Data are reported as follows: $[\alpha]_{\lambda}^{\text {temp }}$, concentration ( $\mathrm{c}$ in $\mathrm{g} / 100 \mathrm{~mL}$ ), and solvent. The enantiomeric excesses were determined by HPLC or GC analysis employing a chiral stationary phase column specified in the individual experiment, by comparing the samples with the appropriate racemic mixtures. 


\section{Reaction Optimization}

\subsection{Screening of Sulfur Donors}

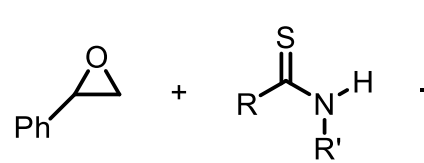

$( \pm)-1 \mathrm{a} \quad 2(0.5-0.6$ equiv $)$

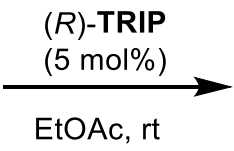

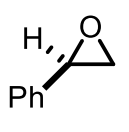

$1 a$

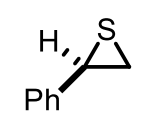

$3 a$

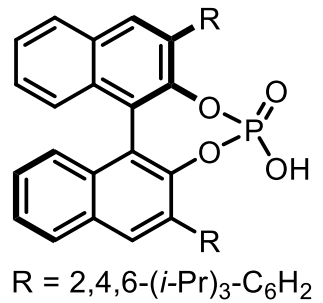

(TRIP)

The reactions were carried out on $0.1 \mathrm{~mol}$ scale with 5 mol\% catalyst loading, and the conversion was determined by ${ }^{1} \mathrm{H}$ NMR.

I.<smiles>NC(N)=S</smiles>

$24 \mathrm{~h}, 50 \%$ conv. $\mathbf{s}=\mathbf{5}$<smiles>NC(=S)Nc1ccccc1</smiles>

$24 \mathrm{~h}, 60 \%$ conv. $\mathrm{s}=7$<smiles>CNC(=S)NC</smiles>

$120 \mathrm{~h}, 19 \%$ conv. $\mathbf{s}=\mathbf{6}$<smiles>S=C(Nc1ccccc1)Nc1ccccc1</smiles>

side reactions $s \sim 7$<smiles>CCCCNC(=S)NC(C)CC</smiles>

$72 \mathrm{~h}, 15 \%$ conv. $\mathrm{s}=\mathbf{5 . 5}$<smiles>CC(C)(C)NC(=S)NC(C)(C)C</smiles>

$72 \mathrm{~h},<5 \%$

II.<smiles>S=C1NCCN1</smiles>

$6 \mathrm{~h}, 55 \%$ conv. $s=10$<smiles>CC1(C)NC(=S)NC1(C)C</smiles>

$24 \mathrm{~h}, 8 \%$ conv. $\mathrm{s}=\mathbf{6}$<smiles>S=C1NCCCN1</smiles>

72 h, $17 \%$ conv. $\mathrm{s}=\mathbf{6}$<smiles>CC(C)NC(=S)NC(C)C</smiles>

$72 \mathrm{~h},<5 \%$

III.<smiles>NC(=S)c1ccccc1</smiles>

8 h, $55 \%$ conv. $\mathbf{s}=\mathbf{9}$<smiles>NC(=S)c1ccccc1</smiles><smiles>CC(N)=S</smiles>

24 h, $40 \%$ conv. $\mathrm{s}=\mathbf{8}$<smiles>NC(=S)c1ccccc1</smiles>

in dioxane, $\mathrm{rt}, 24 \mathrm{~h}$ in dioxane/DCM, $-20^{\circ} \mathrm{C}, 48 \mathrm{~h}$

$46 \%$ conv. $s=13.5$ $55 \%$ conv. $s=26$<smiles>CC(C)C(N)=S</smiles>

$24 \mathrm{~h}, 59 \%$ conv. $\mathbf{s}=\mathbf{9}$<smiles>NP(=S)(c1ccccc1)c1ccccc1</smiles><smiles>S=C1NCCN1c1ccccc1</smiles>

$24 \mathrm{~h}, 54 \%$ conv. $\mathbf{s}=\mathbf{9}$ 
IV. In dioxane/DCM (1:1), $-20^{\circ} \mathrm{C}$<smiles>CC(=O)Oc1ccc(C(N)=S)cc1</smiles>

48 h, $42 \%$ conv. $s=24$<smiles>NC(=S)c1ccc(C(F)(F)F)cc1</smiles>

$48 \mathrm{~h}, 48 \%$ conv. $s=27$<smiles>NC(=S)c1cccc2ccccc12</smiles>

$24 \mathrm{~h}, 48 \%$ conv. $s=26$<smiles>NC(=S)c1c(Cl)cccc1Cl</smiles>

$48 \mathrm{~h}, 47 \%$ conv. $s=13$

V.<smiles>S=C1CCc2ccccc2N1</smiles>

in EtOAc, rt

$2 \mathrm{~h}, 55 \%$ conv. $\mathbf{s}=\mathbf{2 0}$

in $\mathrm{CHCl}_{3},-20^{\circ} \mathrm{C}$ :<smiles>S=C1NCCc2ccccc21</smiles>

$24 \mathrm{~h}, 30 \%$ conv. $\mathrm{s}=12$

Other sulfur donors such as Lawesson's reagent and $\mathrm{Ph}_{3} \mathrm{P}=\mathrm{S}$ did not lead to product formation. KSCN has not been tested.

\subsection{Catalyst Screening}

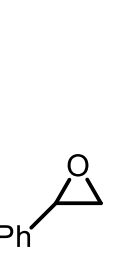

$( \pm)-1 \mathrm{a}$

(1)<smiles>S=C1CCc2ccccc2N1</smiles><smiles>S=C1CCc2ccccc2N1</smiles>
in dioxane/DCM (1:1), $-20{ }^{\circ} \mathrm{C}$ $48 \mathrm{~h}, 51 \%$ conv. $\mathrm{s}=53$

\section{in $\mathrm{CHCl}_{3},-20^{\circ} \mathrm{C}$}
$24 \mathrm{~h}, 48 \%$ conv. $s=86$
$24 \mathrm{~h}, 22 \%$ conv. $\mathrm{s}=14$<smiles>S=C1CCCCN1</smiles>
$24 \mathrm{~h}, 10 \%$ conv. $\mathrm{s}=16$<smiles>CN1C(=S)CCc2ccccc21</smiles>
N.R.

\section{Screening of catalysts with thiourea as the sulfur donor}
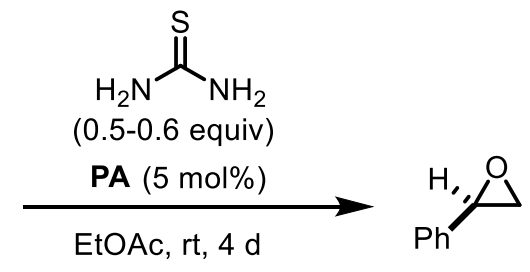
$1 \mathrm{a}$

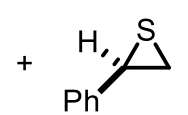
3a<smiles>[R]c1cc2ccccc2c(-c2c(OP(=O)(O)O)c([R])cc3ccccc23)c1O[PH]([R])=O</smiles> 
<smiles>CCCc1cc(C(C)C)c(C(C)C)c(C(C)C)c1</smiles>

$50 \%$ conv., $\mathrm{s}=4.8$<smiles>CC(C)(C)c1ccc(C(C)(C)C)cc1</smiles>

$18 \%$ conv., $\mathbf{s}=1.6$<smiles>CC(C)(C)c1ccccc1</smiles>

$8 \%$ conv., $s=1.4$<smiles>CC(C)(C)c1cc(C(F)(F)F)cc(C(F)(F)F)c1</smiles>

-\{̧-SiPh
$7.2 \%$ conv., $\mathbf{s}=1.1$

$12 \%$ conv., $\mathbf{s}=1.4$

$9 \%$ conv., $s=1.4$<smiles>CC(C)(C)c1ccc2ccccc2c1</smiles><smiles>CC(C)(C)c1ccc(-c2ccccc2)cc1</smiles>

$2 \%$ conv., s $=1.5$
$57 \%$ conv., s $=\mathbf{2} .5$

\section{Screening of catalysts with $2 f$ as the sulfur donor}<smiles>S=C1CCc2ccccc2N1</smiles>

(0.5 equiv)

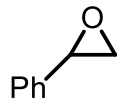

( \pm -1 a

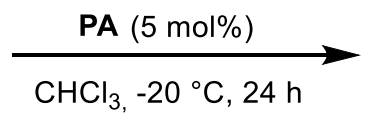

then $\mathrm{rt}, 1 \mathrm{~h}$

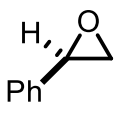

$1 \mathrm{a}$
$+$

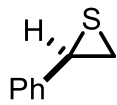

$3 a$<smiles>[R]c1cc2ccccc2c(-c2c([R])cc3ccccc3c2OP(=O)(O)O)c1[R]</smiles>

PA<smiles>CCCCc1cc(C(C)C)cc(P)c1C(C)(C)C</smiles>

$50 \%$ conv., s $=86$<smiles>CC(C)c1cc(C(C)C)c(C(C)(C)C)c(C(C)C)c1</smiles>

$\mathrm{H}_{8}$-TRIP

$49 \%$ conv., $s=68$<smiles>CC(C)(C)c1ccccc1</smiles>

$47 \%$ conv., s $=2.4$<smiles>c1c2c(cc3c1C1CCC3C1)C1CCC2C1</smiles>

$50 \%$ conv., $\mathbf{s}=\mathbf{3 0}$

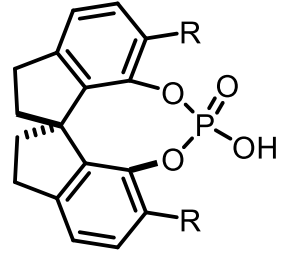

Spiro-TRIP<smiles>[R]C1=CC2CCCCC2C(c2c([R])cc3c(c2OP(=O)(O)O)CCCC3)=C1OP(=O)(O)O</smiles>

$\mathrm{R}=$<smiles>CC(C)c1cc(C(C)C)c(C(C)(C)C)c(C(C)C)c1</smiles>

$$
\mathrm{H}_{8} \text {-TRIP }
$$

All the phosphoric acids are known, and were prepared accroding to our previously reported methods. ${ }^{1}$ 
2.3 Optimization of Reaction Conditions

2.3.1 Solvent Effect

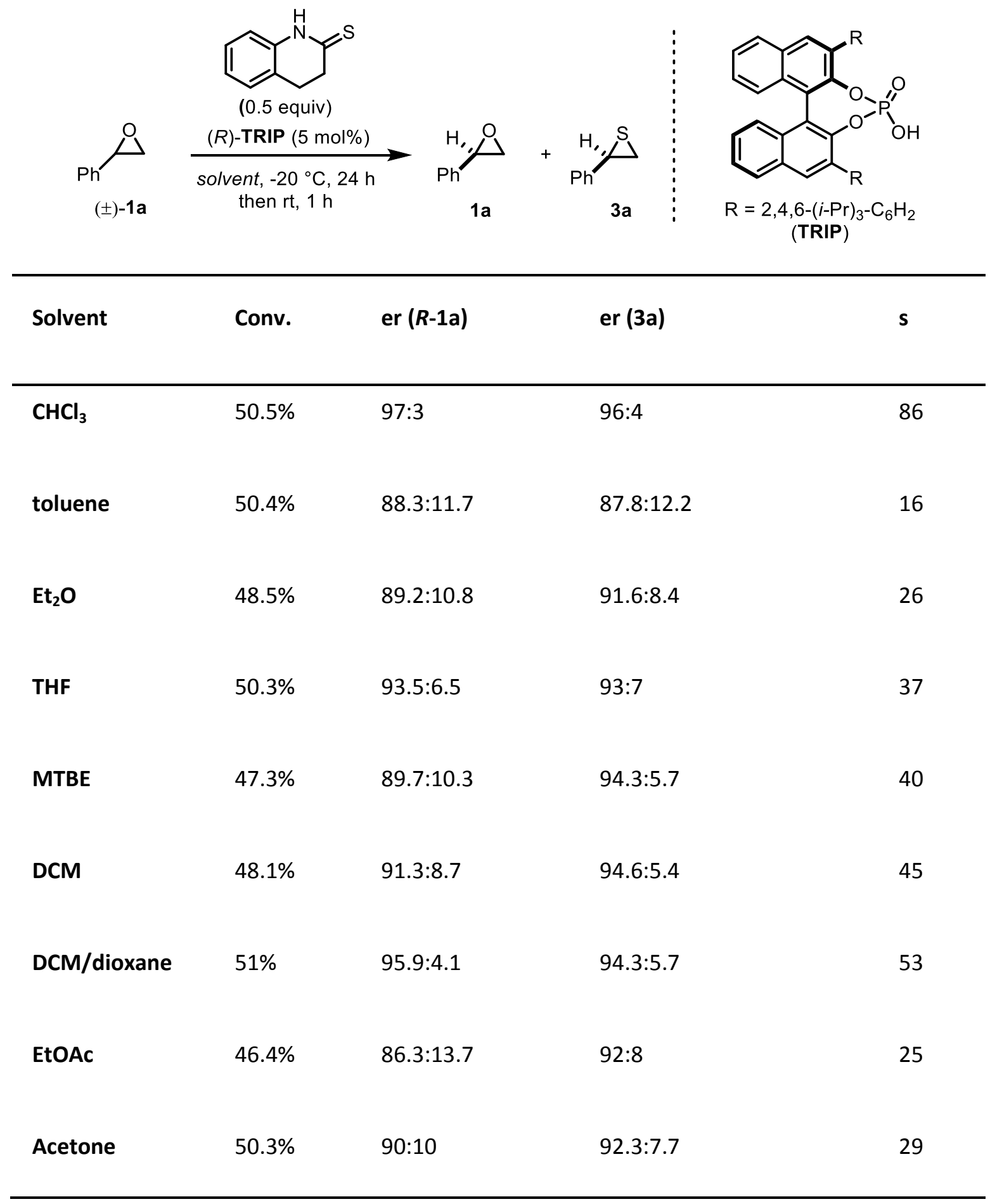


2.3.2 Reaction Concentration

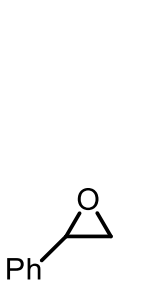

(土)-1a<smiles>S=C1CCc2ccccc2N1</smiles>

(0.5 equiv)

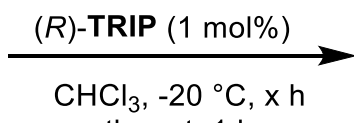

then $\mathrm{rt}, 1 \mathrm{~h}$

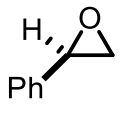

1 a

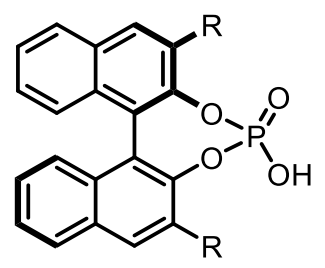

$\mathrm{R}=2,4,6-(i-\mathrm{Pr})_{3}-\mathrm{C}_{6} \mathrm{H}_{2}$ (TRIP)

\begin{tabular}{|c|c|c|c|c|c|}
\hline Conc. & $\mathbf{t}^{\mathrm{a}}$ & Conv. & er $(R-1 a)$ & er (3a) & $\mathbf{s}$ \\
\hline $1.0 \mathrm{~mol} / \mathrm{L}$ & $1 \mathrm{~h}$ & $49.5 \%$ & $94.1: 5.9$ & $95.5: 4.5$ & 55 \\
\hline $0.5 \mathrm{~mol} / \mathrm{L}$ & $5 \mathrm{~h}$ & $49 \%$ & $95.7: 4.3$ & $96.2: 3.8$ & 82 \\
\hline $0.2 \mathrm{~mol} / \mathrm{L}$ & $5 \mathrm{~h}$ & $49.3 \%$ & $95.2: 4.8$ & $96.5: 3.5$ & 86 \\
\hline $0.1 \mathrm{~mol} / \mathrm{L}$ & $12 \mathrm{~h}$ & $49.5 \%$ & $95.5: 4.5$ & $96.6: 3.4$ & 86 \\
\hline $0.05 \mathrm{~mol} / \mathrm{L}$ & $24 \mathrm{~h}$ & $50.2 \%$ & $96.8: 3.2$ & $96: 4$ & 85 \\
\hline $0.01 \mathrm{~mol} / \mathrm{L}$ & $24 \mathrm{~h}$ & $49.5 \%$ & $94.8: 5.2$ & $96.1: 3.9$ & 75 \\
\hline
\end{tabular}




\section{Experiments with Respect to Mechanistic Insight}

\subsection{Match and Mismatch Effect}

The reactions were conducted under the standard condition with $0.1 \mathrm{~mol} \%$ catalyst, using enantioenriched styrene oxide (99:1 er, Alfa-Aesar). After 2 hours, the matched reaction (R-S) gave $60 \%$ conversion, while in the mismatched (R-R) reaction showed less than 3\% conversion of the starting epoxide in the ${ }^{1} \mathrm{H}$ NMR spectrum at this time. This result is in good agreement with the absolute configurations of the recovered epoxide (R-configuration) and the thiirane (R-configuration) obtained with the racemic epoxide and $(R)$-TRIP catalyst. The matched reaction reached $96 \%$ conversion after $48 \mathrm{~h}$, and the product was enantiomerically pure (>99.9:0.1 er).

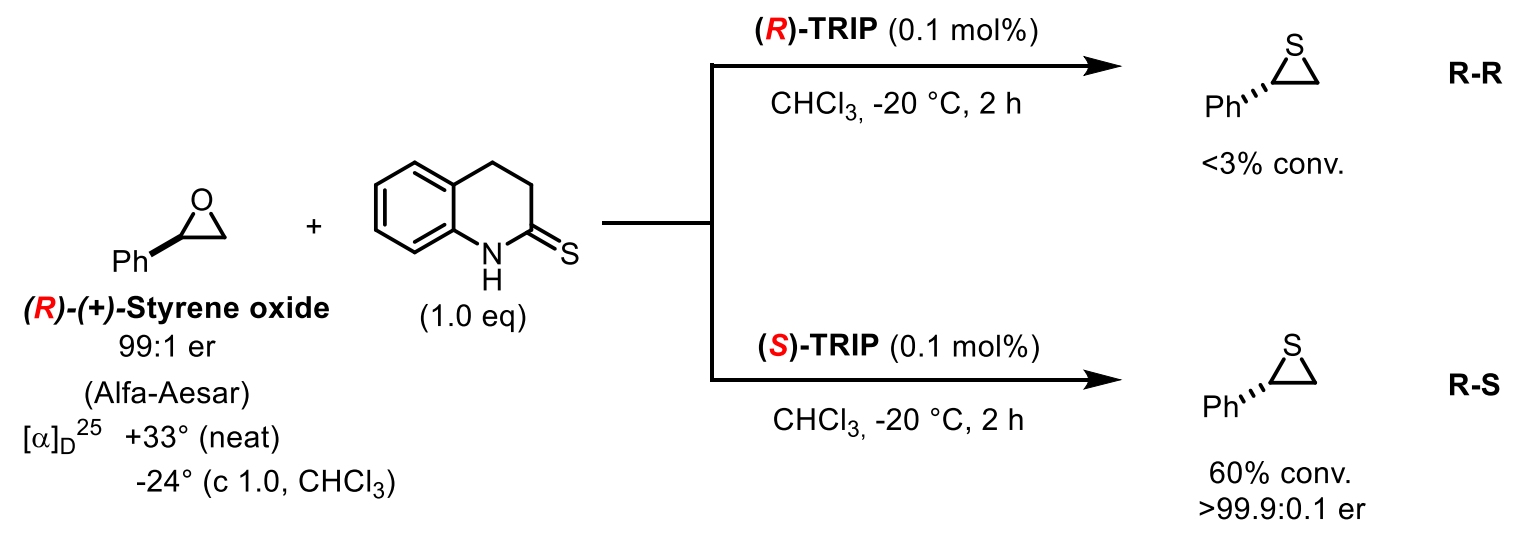

\subsection{Loss of Enantiomeric Purity under Typical Conditions}

The reactions were conducted in methanol $(0.1 \mathrm{~mol} / \mathrm{L})$ with two equivalents of thiourea. Enantioenriched styrene oxide (99:1 er) was used. After 24 hours, 95\% conversion was achieved and the ${ }^{1} \mathrm{H}$ NMR spectrum also showed ca. $5 \%$ of styrene formed. The enantiomeric purity of the thiirane product was determined by GC to be 75:25 er, suggesting a significant loss of the enantiomeric purity under the typical conditions. As shown in the aforementioned reaction (3.1), the catalytic system with TRIP can well maintain the enantiomeric purity from the starting epoxide.

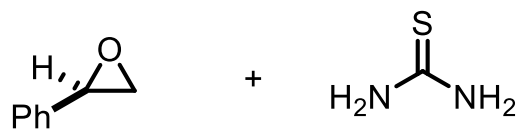

$(R)-(+)$-Styrene oxide 99:1 er

(2.0 eq)

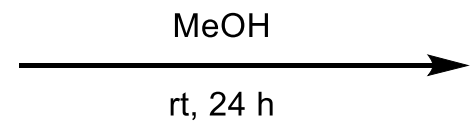

$\mathrm{rt}, 24 \mathrm{~h}$

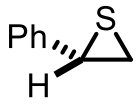

$95 \%$ conv., $5 \%$ styrene 75:25 er 


\subsection{Binding of $2 f$ to the Acid Catalyst}

Once the thiolactam $2 \mathbf{f}$ was methylated, no reaction was observed under standard conditions at $-20{ }^{\circ} \mathrm{C}$. Even at room temperature for $12 \mathrm{~h}$ (see below), only a trace amount of the thiirane product was observed by ${ }^{1} \mathrm{H}$ NMR or TLC. In comparison, under the same condition, the reaction with $\mathbf{2 f}$ only requires $\mathbf{2 5} \mathbf{m i n}$ to complete and reach full conversion of the sulfur donor. Moreover, in the reaction with $\mathbf{2 h}$, the acid catalyst was found to be completely degraded in the end, in a sharp contrast to the reaction with $\mathbf{2 f}$.

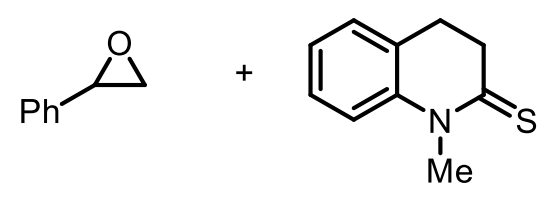

2h (0.50 eq)

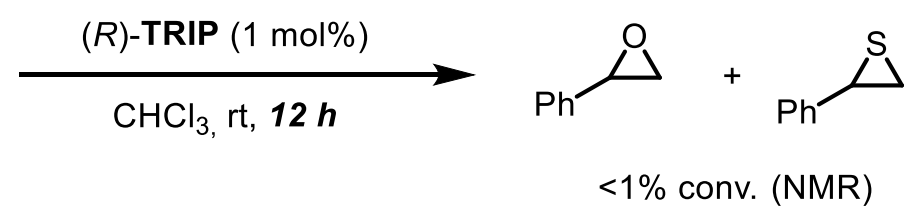

NV. (NMR)
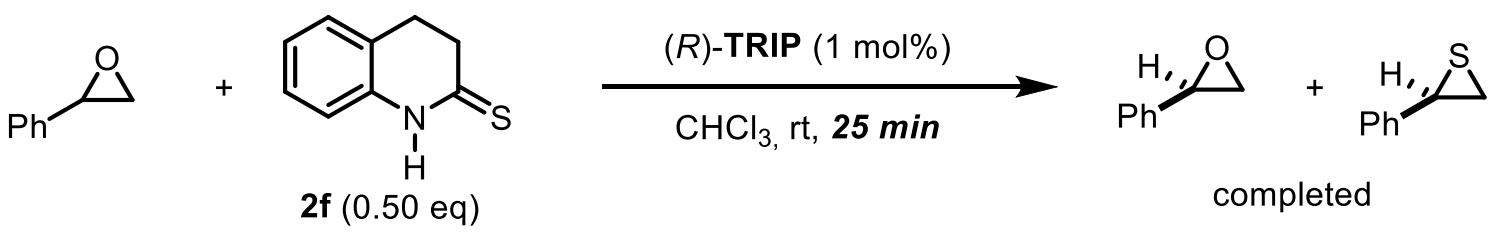

These results suggested the N-H part in $\mathbf{2 f}$ is crucial to the success of the current catalytic system, which is supposed to form H-bond with the acid catalyst TRIP. This heterodimer formation not only provides a protection of the catalyst against the attack by epoxides, but also achieves the activation of the substrates.

\subsection{Association Constants of Heterodimers}

The association constants of TRIP.2f and TRIP.2i (lactam) were tentatively measured through NMR experiments via titration of the chemical shift of the phosphorous peak of TRIP upon the addition of $\mathbf{2} \mathbf{f}$ or $\mathbf{2} \mathbf{i}$ into the mixture, according to our previously reported method. ${ }^{1}$ And the results showed that the binding $\left(K_{\mathrm{a}}=1750 \pm 50\right)$ of $\mathbf{2 i}$ to TRIP is much stronger than that $\left(K_{\mathrm{a}}=48 \pm 1\right)$ of $\mathbf{2 f}$, thus both heterodimers should contribute to the catalyst protection.

\section{Determination of the binding constant of TRIP.2f}

The ${ }^{31} \mathrm{P}$ NMR experiment was conducted in $\mathrm{CD}_{2} \mathrm{Cl}_{2}$, with $85 \% \mathrm{H}_{3} \mathrm{PO}_{4}$ as an external standard. $3.0 \mathrm{mg}$ of $(R)$-TRIP was dissolved in $2 \mathrm{~mL}$ of $\mathrm{CD}_{2} \mathrm{Cl}_{2}$, and a certain amount of thiolactam $2 \mathbf{f}$ was added according to each entry. To ensure that the concentration of the solution remains constant, the solvent level was marked on the NMR tube and refilled with $\mathrm{CD}_{2} \mathrm{Cl}_{2}$ or evaporated accordingly. The ratios of $\mathbf{2 f} / \mathbf{T R I P}$ were determined by ${ }^{1} \mathrm{H}$ NMR. 


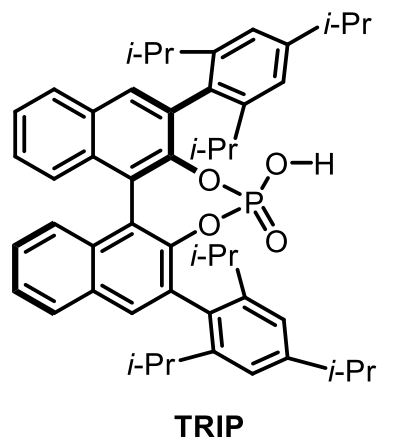

TRIP<smiles>S=C1CCc2ccccc2N1</smiles>

2f

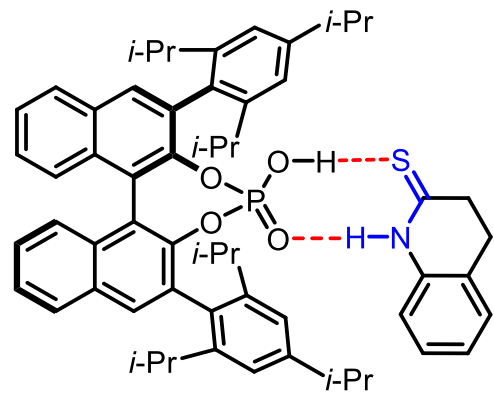

TRIP.2f

Exp. 1

\begin{tabular}{cccc}
\hline entry & ratio $(\mathbf{2 f} / \mathbf{T R I P})$ & {$[\mathbf{2 f}] / \mathbf{M}$} & $\boldsymbol{\delta}\left({ }^{\mathbf{3 1}} \mathbf{P}\right) / \mathbf{p p m}$ \\
\hline 1 & 0.0000 & 0.0000 & 2.9980 \\
2 & 0.4032 & 0.0008 & 3.0165 \\
3 & 1.3624 & 0.0027 & 3.0942 \\
4 & 2.3342 & 0.0046 & 3.1495 \\
5 & 3.2550 & 0.0065 & 3.2065 \\
6 & 4.7268 & 0.0094 & 3.2787 \\
7 & 6.4778 & 0.0129 & 3.3612 \\
8 & 10.2838 & 0.0205 & 3.4798 \\
9 & 13.8820 & 0.0277 & 3.5583 \\
10 & 19.5950 & 0.0390 & 3.6304 \\
11 & 25.8144 & 0.0514 & 3.6821 \\
12 & 33.0102 & 0.0658 & 3.7240 \\
\hline
\end{tabular}

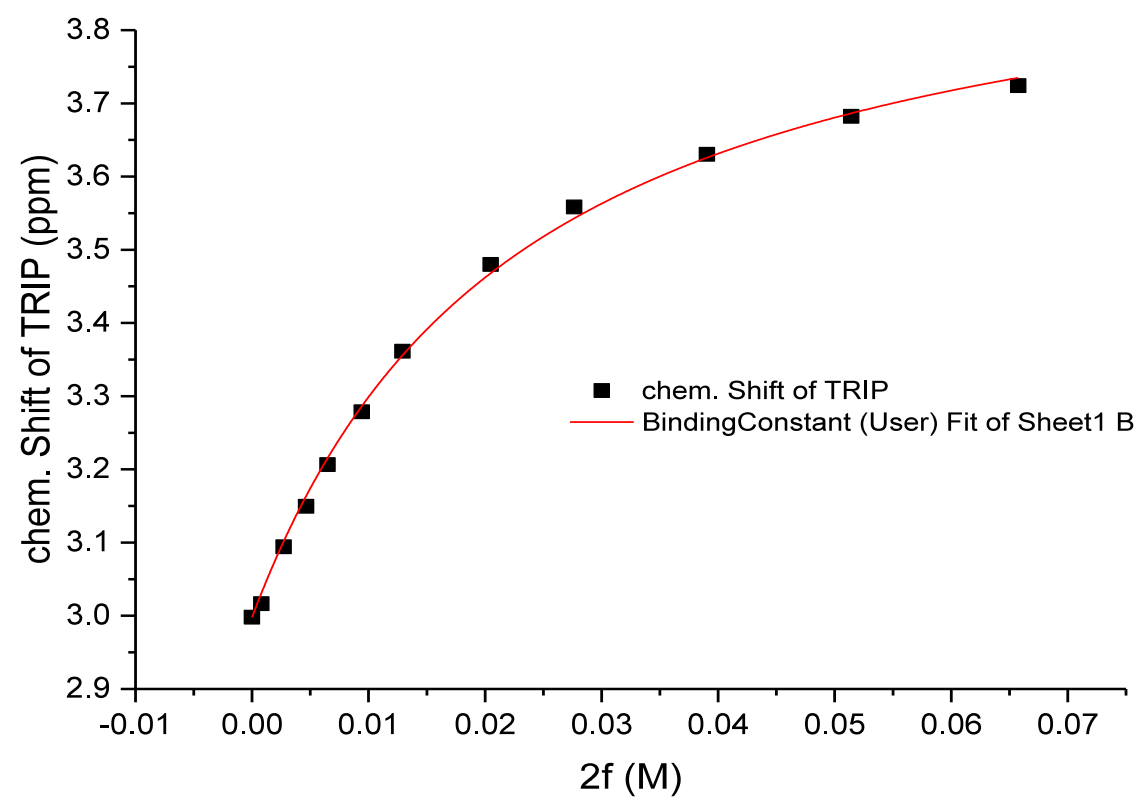


Parameters used for non-linear regression:

\begin{tabular}{cc}
\hline parameter & value \\
\hline$\delta_{\mathrm{TR} I P}$ & $2.9980 \mathrm{ppm}$ \\
{$\left[\mathrm{H}_{0}\right] / \mathrm{M}$} & 0.001992
\end{tabular}

Obtained parameters after non-linear regression:

\begin{tabular}{ccc}
\hline parameter & value & standard error \\
\hline$\delta_{\mathrm{HG}}(\mathrm{ppm})$ & 3.9778 & 0.0204 \\
$\mathrm{~K}\left(\mathrm{M}^{-1}\right)$ & 47.214 & 2.411 \\
red. $\chi^{2}$ & $1.67 \mathrm{E}-4$ & \\
Res. Sum & 0.00117 & \\
of squares & & \\
Adj. $\mathrm{R}^{2}$ & 0.9983 &
\end{tabular}

Exp. 2

\begin{tabular}{cccc}
\hline entry & ratio $(\mathbf{2 f} / \mathbf{T R I P})$ & {$[\mathbf{2 f}] / \mathbf{M}$} & $\mathbf{\delta}\left({ }^{\mathbf{3 1}} \mathbf{P}\right) / \mathbf{p p m}$ \\
\hline 1 & 0.0000 & 0.0000 & 3.0514 \\
2 & 0.4528 & 0.0009 & 3.0878 \\
3 & 1.3102 & 0.0026 & 3.1365 \\
4 & 2.3886 & 0.0048 & 3.1951 \\
5 & 3.4248 & 0.0068 & 3.2457 \\
6 & 4.6048 & 0.0092 & 3.2970 \\
7 & 5.9720 & 0.0119 & 3.3532 \\
8 & 9.7498 & 0.0194 & 3.4715 \\
9 & 13.2226 & 0.0263 & 3.5338 \\
10 & 17.9234 & 0.0357 & 3.5924 \\
11 & 22.9802 & 0.0458 & 3.6383 \\
12 & 31.3604 & 0.0625 & 3.6785 \\
\hline
\end{tabular}




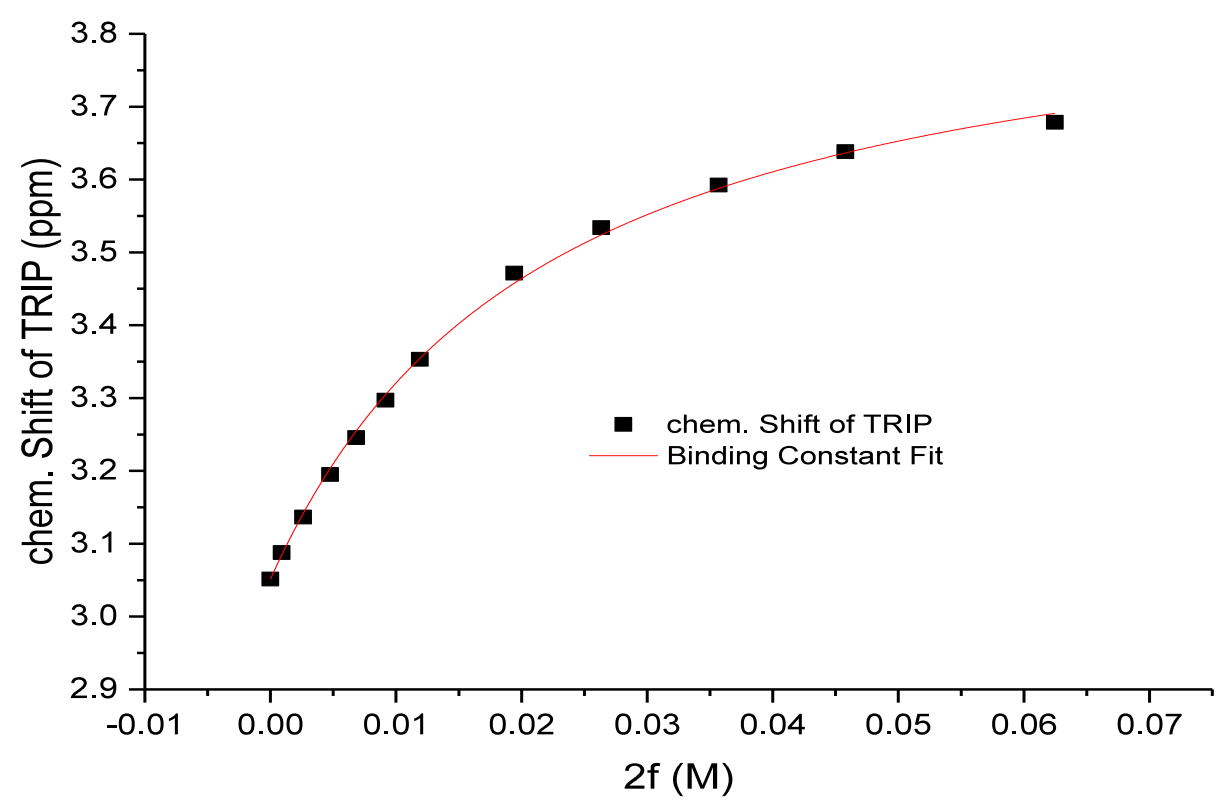

Parameters used for non-linear regression:

\begin{tabular}{cc}
\hline parameter & value \\
\hline$\delta_{\mathrm{TRIP}}$ & $2.9980 \mathrm{ppm}$
\end{tabular}

$\left[\mathrm{H}_{0}\right] / \mathrm{M} \quad 0.001992$

Obtained parameters after non-linear regression:

\begin{tabular}{ccc}
\hline parameter & value & standard error \\
\hline$\delta_{\mathrm{HG}}(\mathrm{ppm})$ & 3.9036 & 0.0165 \\
$\mathrm{~K}\left(\mathrm{M}^{-1}\right)$ & 49.326 & 2.295 \\
red. $\chi^{2}$ & $7.14 \mathrm{E}-5$ & \\
Res. Sum & $7.14 \mathrm{E}-4$ & \\
of squares & 0.9985 & \\
Adj. $\mathrm{R}^{2}$ &
\end{tabular}

Averaging of the two Experiments

\begin{tabular}{ccc}
\hline entry & $\mathbf{K} / \mathbf{M}^{-1}$ & error $/ \mathbf{M}^{-1}$ \\
\hline Exp. 1 & 47.214 & 2.411 \\
Exp 2 & 49.326 & 2.295 \\
\hline Average & $\underline{\underline{48.270}}$ & $\underline{\underline{1,056}}$ \\
\hline
\end{tabular}

The error of the average was obtained from the standard deviation of the average. 


\section{Determination of the binding constant of TRIP. $2 \mathrm{i}$}

The ${ }^{31} \mathrm{P}$ NMR experiment was conducted in $\mathrm{CD}_{2} \mathrm{Cl}_{2}$, with $85 \% \mathrm{H}_{3} \mathrm{PO}_{4}$ as an external standard. $3.0 \mathrm{mg}$ of $(R)$-TRIP was dissolved in $2 \mathrm{~mL}$ of $\mathrm{CD}_{2} \mathrm{Cl}_{2}$, and a certain amount of lactam $2 \mathbf{i}$ was added according each entry, and make the volume of $\mathrm{CD}_{2} \mathrm{Cl}_{2}$ solvent of no change by marking a line on the NMR tube and refill or evaporate $\mathrm{CD}_{2} \mathrm{Cl}_{2}$ in time. The ratios of 2i/TRIP were determined by ${ }^{1} \mathrm{H}$ NMR.

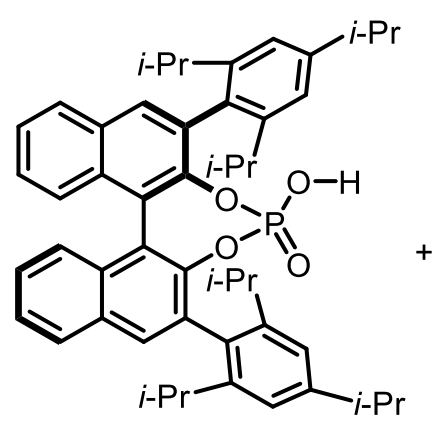

TRIP<smiles>O=C1CCc2ccccc2N1</smiles>

$2 \mathbf{i}$

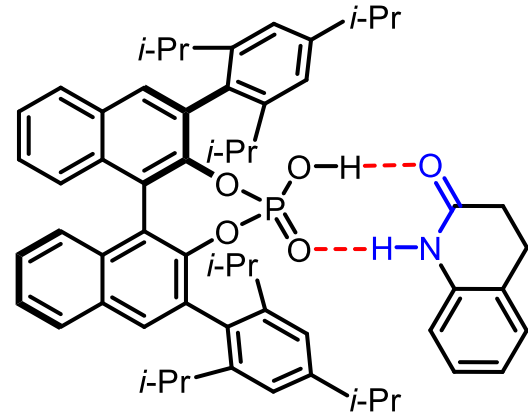

TRIP·2i

Exp. 1

\begin{tabular}{cccc}
\hline entry & ratio (2i/TRIP) & {$[\mathbf{2 i}] / \mathbf{M}$} & $\boldsymbol{\delta}\left({ }^{\mathbf{3}} \mathbf{P}\right) / \mathbf{p p m}$ \\
\hline 1 & 0.0000 & 0.0000 & 3.0333 \\
2 & 0.2258 & 0.0004 & 3.2506 \\
3 & 0.3932 & 0.0008 & 3.3783 \\
4 & 0.6460 & 0.0013 & 3.5346 \\
5 & 0.9416 & 0.0019 & 3.7002 \\
6 & 1.2568 & 0.0025 & 3.8542 \\
7 & 1.5006 & 0.0030 & 3.9601 \\
8 & 1.8640 & 0.0037 & 4.0334 \\
9 & 2.1530 & 0.0043 & 4.0757 \\
10 & 2.7650 & 0.0055 & 4.1300 \\
11 & $3, .4642$ & 0.0069 & 4.1611 \\
12 & $4, .0792$ & 0.0081 & 4.1866 \\
13 & 4.7940 & 0.0096 & 4.1939 \\
14 & 5.9774 & 0.0119 & 4.2071 \\
15 & 7.3842 & 0.0147 & 4.2168 \\
16 & 9.7150 & 0.0194 & 4.2201 \\
\hline
\end{tabular}




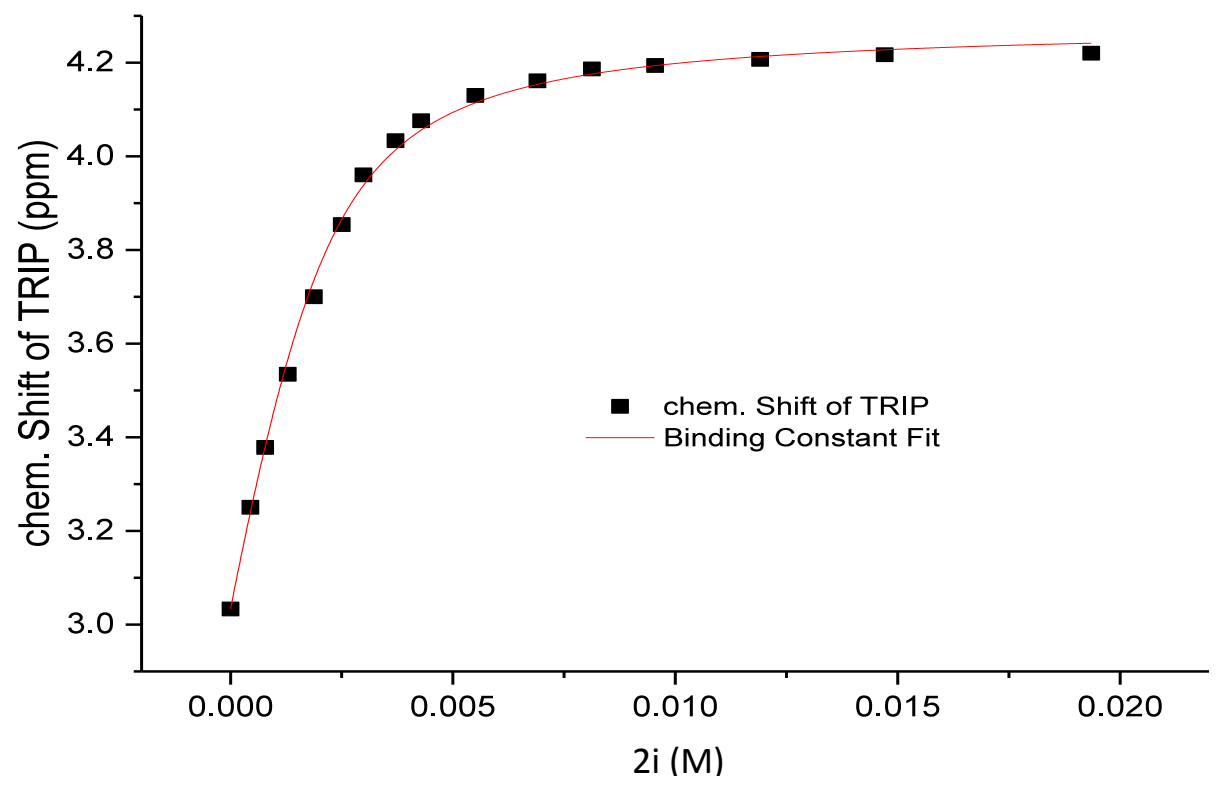

Parameters used for non-linear regression:

\begin{tabular}{cc}
\hline Parameter & value \\
\hline$\delta_{\mathrm{TRIP}}$ & $3.0333 \mathrm{ppm}$ \\
{$\left[\mathrm{H}_{0}\right] / \mathrm{M}$} & 0.001992
\end{tabular}

Obtained parameters after non-linear regression:

\begin{tabular}{ccc}
\hline parameter & value & standard error \\
\hline$\delta_{\mathrm{HG}}(\mathrm{ppm})$ & 4.2824 & 0.0115 \\
$\mathrm{~K}\left(\mathrm{M}^{-1}\right)$ & 1700.193 & 114.266 \\
red. $\chi^{2}$ & $3.39 \mathrm{E}-4$ & \\
Res. Sum & 0.00475 & \\
of squares & & \\
Adj. $\mathrm{R}^{2}$ & 0.9977 &
\end{tabular}


Exp. 2

\begin{tabular}{cccc}
\hline entry & ratio (2i/TRIP) & {$[\mathbf{2 i}] / \mathbf{M}$} & $\boldsymbol{\delta}\left({ }^{31} \mathbf{P}\right) / \mathbf{p p m}$ \\
\hline 1 & 0.0000 & 0.0000 & 3.0263 \\
2 & 0.2482 & 0.0005 & 3.2703 \\
3 & 0.4724 & 0.0009 & 3.4199 \\
4 & 0.6998 & 0.0014 & 3.5707 \\
5 & 0.9674 & 0.0019 & 3.7430 \\
6 & 1.3038 & 0.0026 & 3.9055 \\
7 & 1.6468 & 0.0033 & 3.9988 \\
8 & 1.9706 & 0.0039 & 4.0504 \\
9 & 2.2680 & 0.0045 & 4.0937 \\
10 & 2.8958 & 0.0058 & 4.1485 \\
11 & 3.5750 & 0.0071 & 4.1790 \\
12 & 4.2570 & 0.0085 & 4.1958 \\
13 & 5.0260 & 0.0100 & 4.2083 \\
14 & 6.6860 & 0.0133 & 4.2234 \\
15 & 8.0366 & 0.0160 & 4.2271 \\
16 & 9.9510 & 0.0198 & 4.2278 \\
\hline
\end{tabular}

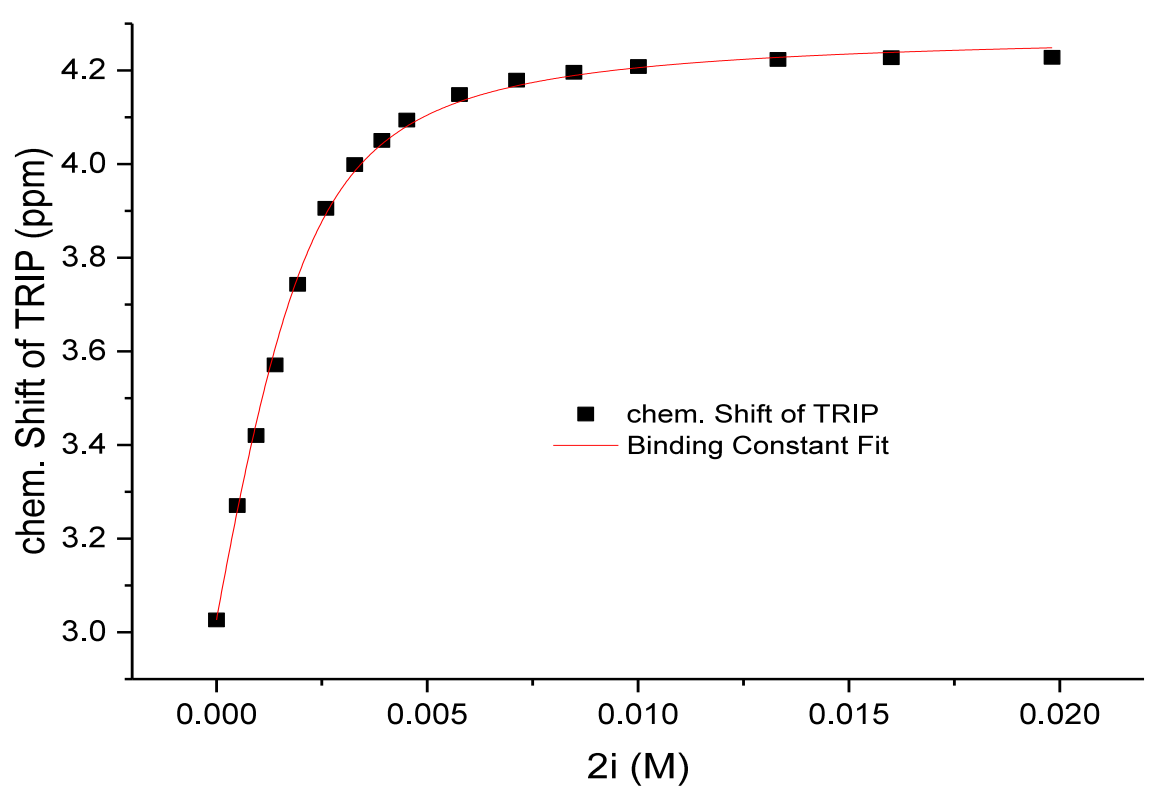

Parameters used for non-linear regression:

\begin{tabular}{cc}
\hline parameter & value \\
\hline$\delta_{\mathrm{TRIP}}$ & $3.0263 \mathrm{ppm}$ \\
{$\left[\mathrm{H}_{0}\right]$} & 0.001992
\end{tabular}

Obtained parameters after non-linear regression: 


\begin{tabular}{ccc}
\hline parameter & value & standard error \\
\hline $\boldsymbol{\delta}_{\mathrm{HG}}(\mathbf{p p m})$ & 4.2863 & 0.0100 \\
$\mathrm{~K}\left(\mathrm{M}^{-1}\right)$ & 1801.067 & 109.733 \\
red. $\chi^{2}$ & $2.82 \mathrm{E}-4$ & \\
Res. Sum & 0.00394 & \\
of squares & & \\
Adj. $\mathrm{R}^{2}$ & 0.99811 &
\end{tabular}

Averaging of the two Experiments

\begin{tabular}{ccc}
\hline entry & $\mathbf{K} / \mathbf{M}^{-1}$ & error $/ \mathbf{M}^{-1}$ \\
\hline Exp. 1 & 1.700 .193 & 114.266 \\
Exp 2 & 1.801 .067 & 109.733 \\
\hline Average & $\underline{\underline{1.750 .630}}$ & $\underline{\underline{50.437}}$ \\
\hline
\end{tabular}

\subsection{Reaction Monitoring by ${ }^{1}$ H NMR Spectroscopy}

In order to investigate the product formation, we monitored the reaction by ${ }^{1} \mathrm{H}$ NMR spectroscopy. Therefore ( \pm )-1a (12 $\mathrm{mg}, 0.1 \mathrm{mmol}, 1$ equiv.) and $\mathbf{2 f}(8.1 \mathrm{mg}, 0.05 \mathrm{mmol}, 0.5$ equiv.) were dissolved in $\mathrm{CDCl}_{3}$ and cooled to $-78{ }^{\circ} \mathrm{C}$. After addition of (R)-TRIP (stock solution in $\mathrm{CDCl}_{3}: 0.01 \mathrm{~mol} / \mathrm{L}, 10 \mu \mathrm{L}, 0.1 \mu \mathrm{mol}, 0.001$ equiv), the NMR sample was shaken and then monitored at $-20{ }^{\circ} \mathrm{C}$. In the initial $2 \mathrm{~h}$ of the reaction a ${ }^{1} \mathrm{H}$ NMR spectrum $(\mathrm{zg} 30$, $\mathrm{d}_{1}=1 \mathrm{~s}, \mathrm{~ns} 16$ ) was acquired every $10 \mathrm{~min}$.

During the measurement we can observe a rapid formation of the intermediates $\mathbf{B}, \mathbf{C}$ and $\mathbf{D}$. and a rapid decrease of concentration of epoxide and thiolactam 2e. The ratio of the intermediates does not change significantly over the reaction course suggesting the equilibrium between these intermediates.

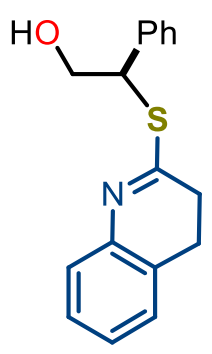

B

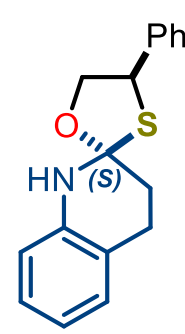

(S)-C

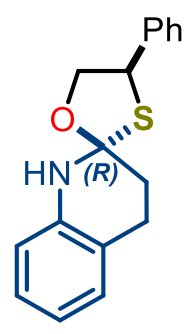

(R)-C<smiles>SC(COC1=Nc2ccccc2CC1)c1ccccc1</smiles>

D

Compared to this, the formation of the desired thiirane is much slower and its formation occurs in parallel with the formation of lactam $2 \mathbf{i}$. This is in good agreement to our proposed 
mechanism. Overall this kinetic analysis supports that the step from the intermediates $\mathbf{D}$ to the product is the rate determining step of the transformation.

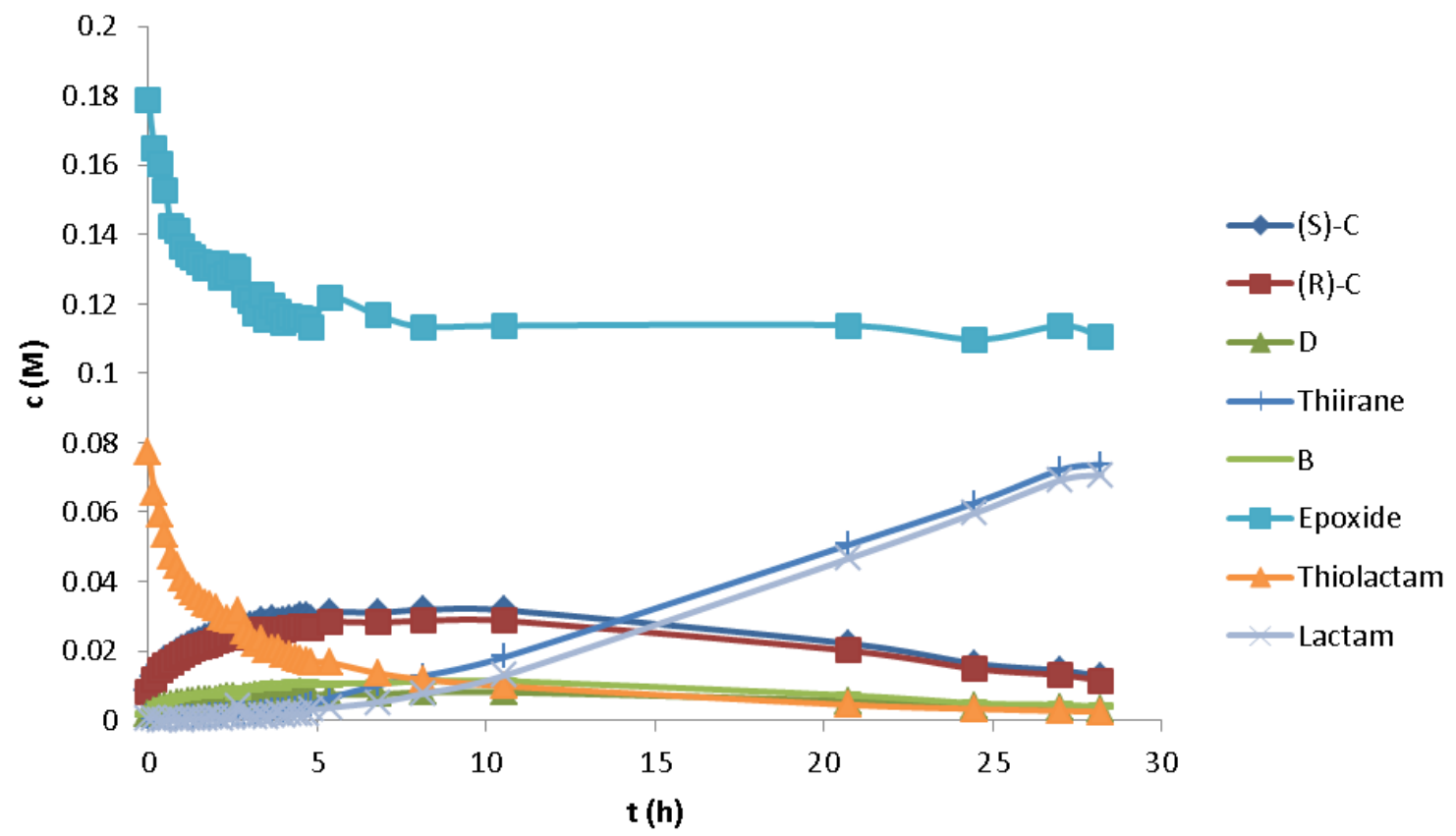

Figure 3.1: Concentration change of the species during the reaction at $-20{ }^{\circ} \mathrm{C}$ monitored by ${ }^{1} \mathrm{H}$ NMR

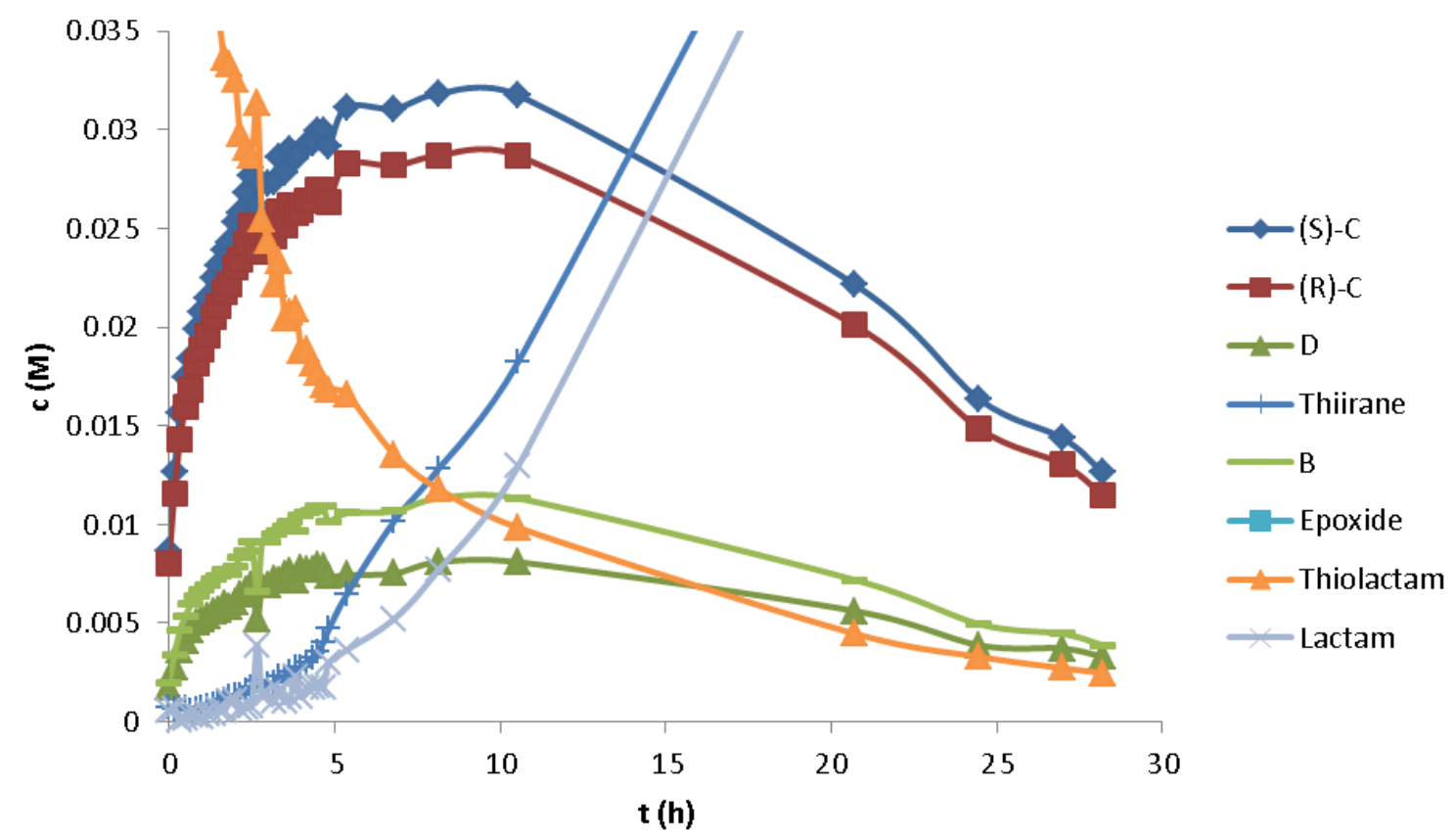

Figure 3.2: Concentration change of the intermediated $\mathrm{B}, \mathrm{C}$ and $\mathrm{D}$ during the reaction at $-20{ }^{\circ} \mathrm{C}$ monitored by ${ }^{1} \mathrm{H}$ NMR 


\subsection{NMR Characterization of Reaction Intermediates}

The observed intermediates were characterized by ${ }^{1} \mathrm{H},{ }^{13} \mathrm{C},{ }^{1} \mathrm{H}-{ }^{1} \mathrm{H}-\mathrm{COSY},{ }^{1} \mathrm{H}-{ }^{13} \mathrm{C}-\mathrm{HSQC}$, ${ }^{1} \mathrm{H}-{ }^{13} \mathrm{C}-\mathrm{HMBC},{ }^{1} \mathrm{H}-{ }^{15} \mathrm{~N}-\mathrm{HMBC}$ and ${ }^{1} \mathrm{H}-{ }^{1} \mathrm{H}-\mathrm{NOESY}$ experiments at $-20{ }^{\circ} \mathrm{C}$ during the reaction (for conditions see 3.5). Due to high overlap of several in the aromatic region and a limited measurement time due to an ongoing reaction, an exact assignment of all the signals in the ${ }^{13} \mathrm{C}$ NMR could not be achieved. The given chemical shifts were therefore extracted from the 2DNMR data.

Proton chemical shifts are reported in ppm $(\delta)$ relative to tetramethylsilane (TMS $\delta=0.00$ $\mathrm{ppm}) .{ }^{2}$ The ${ }^{13} \mathrm{C}$ data was referenced indirectly to the referenced proton frequency with the $\Xi$ scale. $^{3-4}$

\section{Intermediate B}

The NMR signals of this intermediate were broadened due to chemical exchange to $\mathbf{C}$ (see 3.7). An unambiguous assignment could only be achieved for C-13 and C-14, while B can be trapped with isocyanate (see 3.8 ).

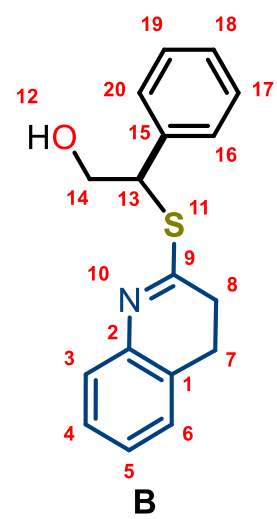

Table 3.1: Chemical Shifts Assignments of B and Cross Peaks Observed in the 2D-NMR Measurements

\begin{tabular}{|rccc|}
\hline Atom & Chemical Shift & COSY & HSQC \\
\hline $13 \mathrm{C}$ & 52.53 & & 13 \\
\hline $\mathrm{H}$ & 5.13 & 14 & 13 \\
\hline $14 \mathrm{C}$ & 69.47 & & 14 \\
\hline $\mathrm{H} 2$ & 4.23 & 13 & 14 \\
\hline
\end{tabular}


Intermediate $(S)$-C
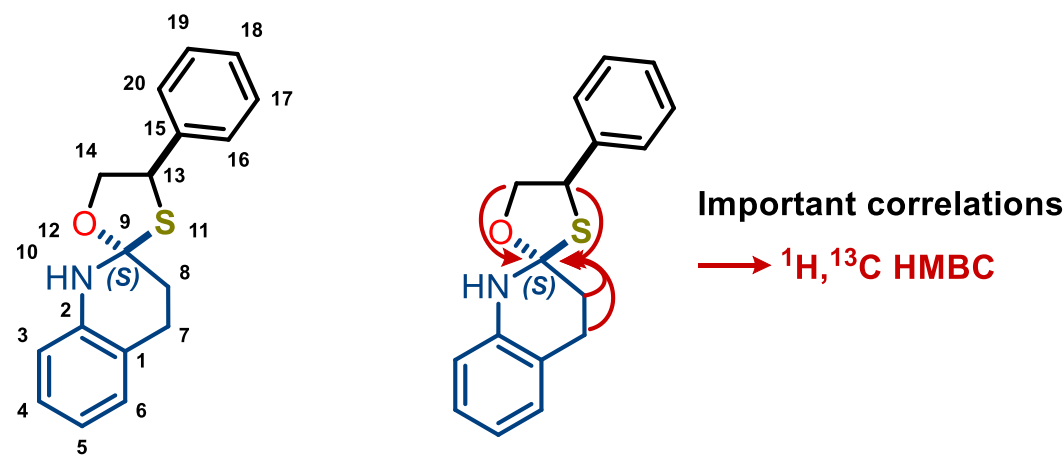

(S)-C

Table 3.2: Chemical Shifts Assignments of (S)-C and Cross Peaks Observed in the 2DNMR Measurements

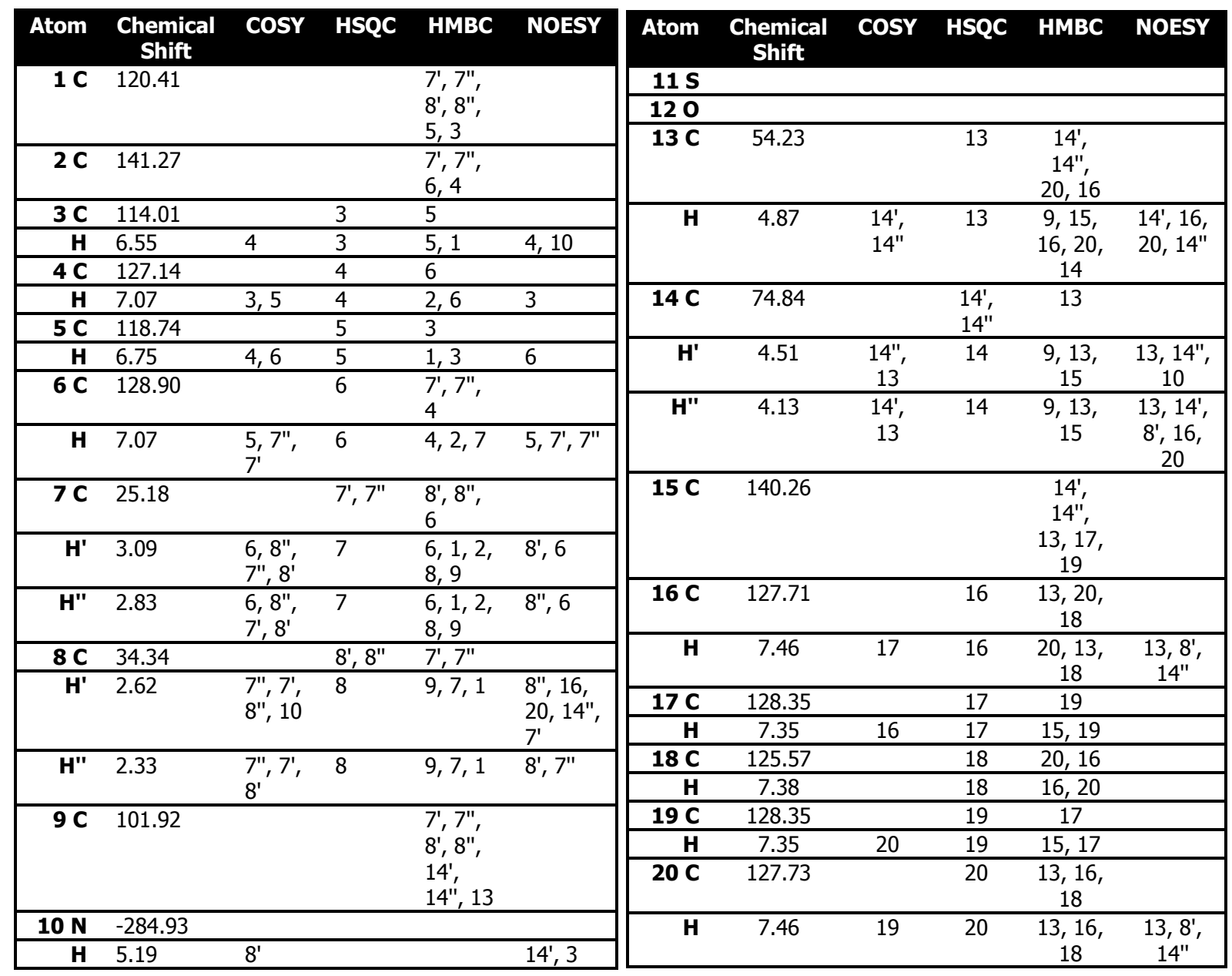




\section{Determination of the Relative Configuration by NOE Correlations}

After a conformational analysis with Spartan '08 (Version 1.2.0, Build 132, Wavefunction Inc.) and optimization of the conformers by DFT (B3LYP/6-31G*), three potential conformers were found ( $\Delta \mathrm{E}<3 \mathrm{~kJ} / \mathrm{mol})$. After comparing the observed NOE cross peaks with the structures, the low energy conformers $(\Delta \mathrm{E}<1 \mathrm{~kJ} / \mathrm{mol})$ explain the observed NOEs in good agreement and therefore the diastereomer was assigned to $(S)-\mathbf{C}$.
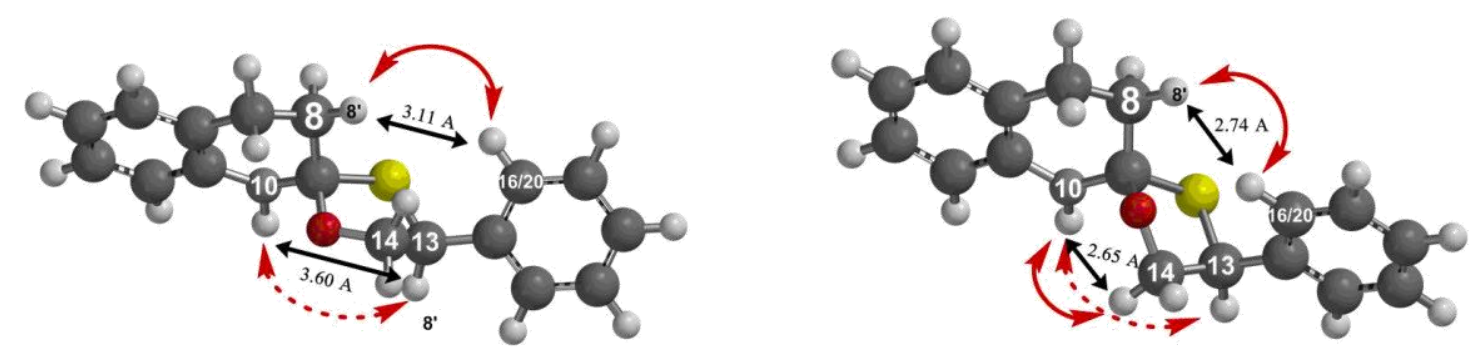

$\Delta E\left(B 3 L Y P, 6-31 G^{*}\right)=0.00 \mathrm{~kJ} / \mathrm{mol}$

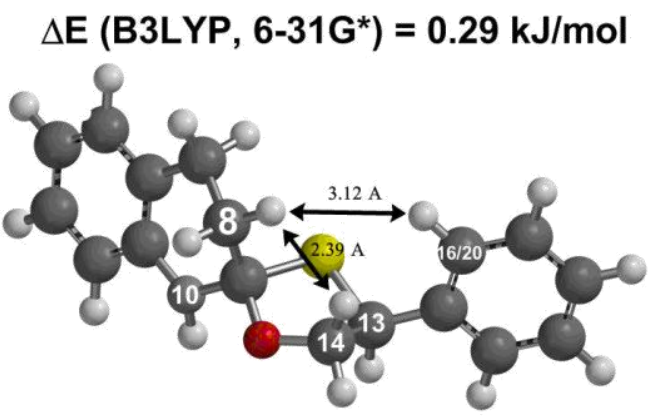

(S)-C

calculated distance observed NOE

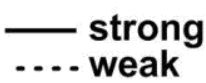

$\Delta \mathrm{E}\left(\mathrm{B} 3 \mathrm{LYP}, 6-31 \mathrm{G}^{*}\right)=2.4 \mathrm{~kJ} / \mathrm{mol}$ 
Intermediate $(\boldsymbol{R})-\mathrm{C}$
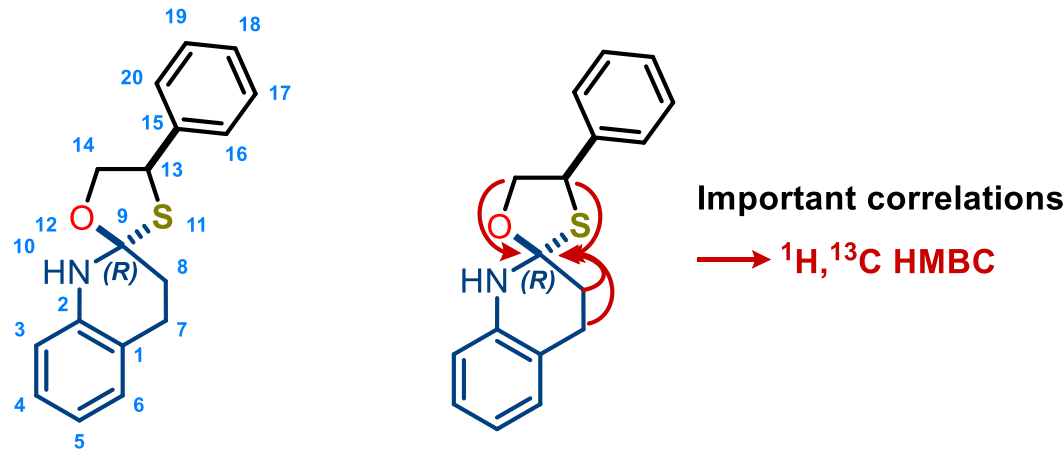

(R)-C

Table 3.3: Chemical Shifts Assignments of the (R)-C and Cross Peaks Observed in the 2D-NMR Measurements

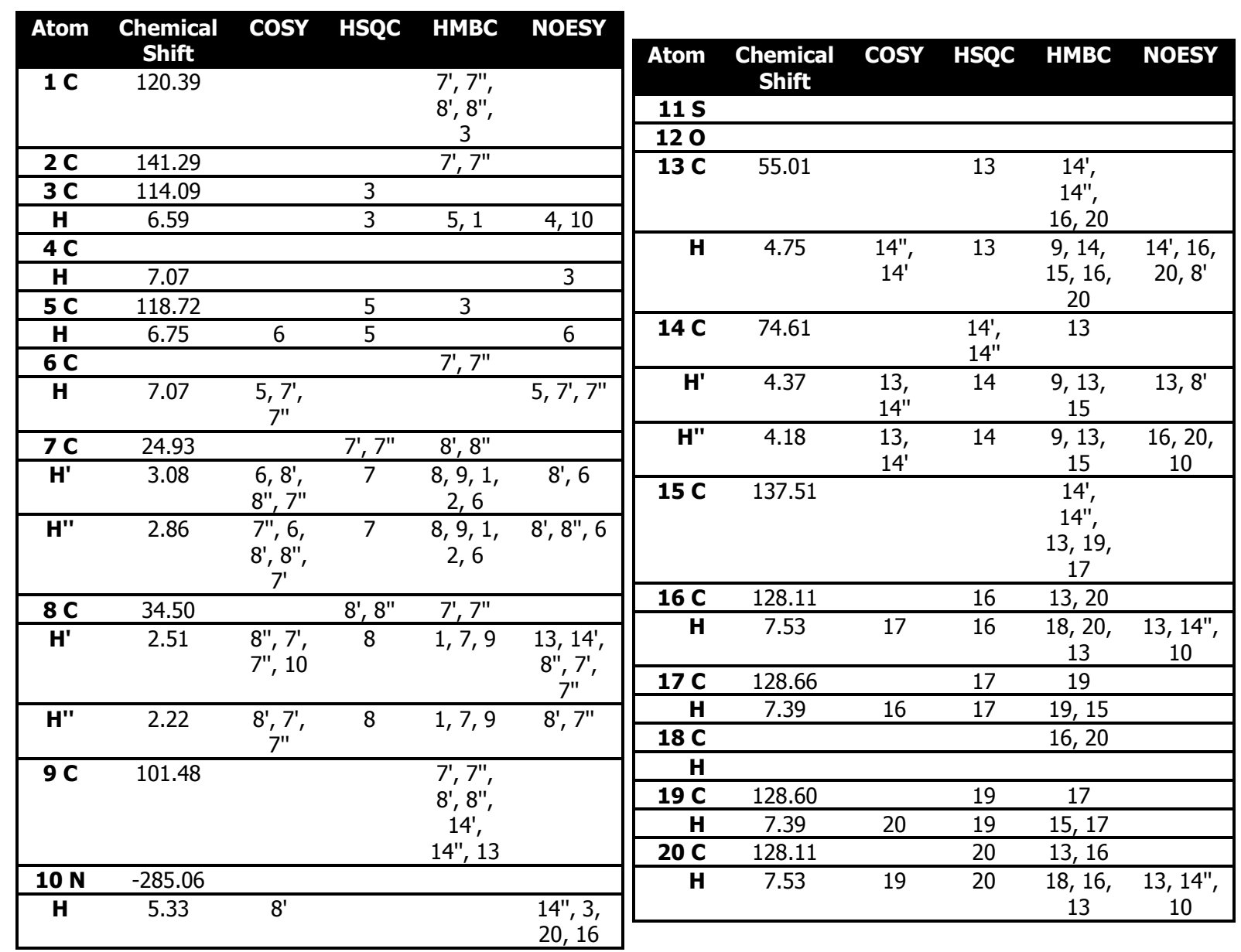




\section{Determination of the Relative Configuration by NOE Correlations}

After a conformational analysis with Spartan '08 (Version 1.2.0, Build 132, Wavefunction Inc.) and optimization of the conformers by DFT (B3LYP/6-31G*), two potential conformers were found $(\Delta \mathrm{E}<3 \mathrm{~kJ} / \mathrm{mol})$. After comparing the observed NOE cross peaks with the structures, the low energy conformers $(\Delta \mathrm{E}<1 \mathrm{~kJ} / \mathrm{mol})$ explain the observed NOEs in good agreement and therefore the diastereomer was assigned to $(R)-\mathbf{C}$.

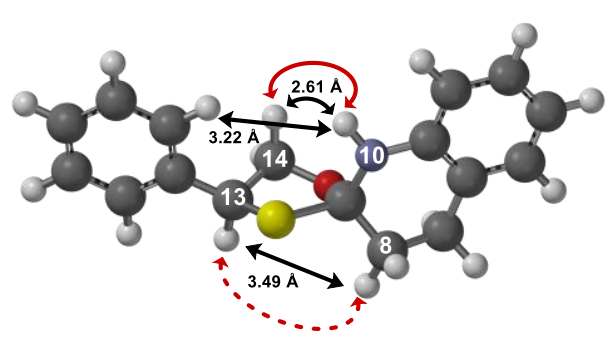

$\Delta \mathrm{E}=0.00 \mathrm{kcal} / \mathrm{mol}$

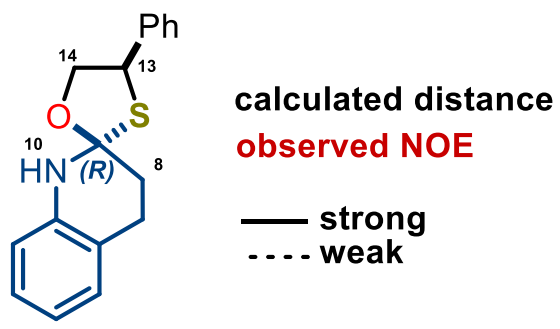

(R)-C

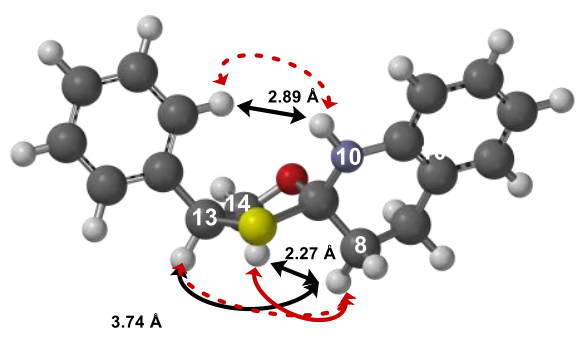

$\Delta \mathrm{E}\left(\mathrm{B} 3 \mathrm{LYP}, 6-31 \mathrm{G}^{*}\right)=0.39 \mathrm{kcal} / \mathrm{mol}$ 
$\underline{\text { Intermediate D }}$<smiles>SC(COC1=Nc2ccccc2CC1)c1ccccc1</smiles>

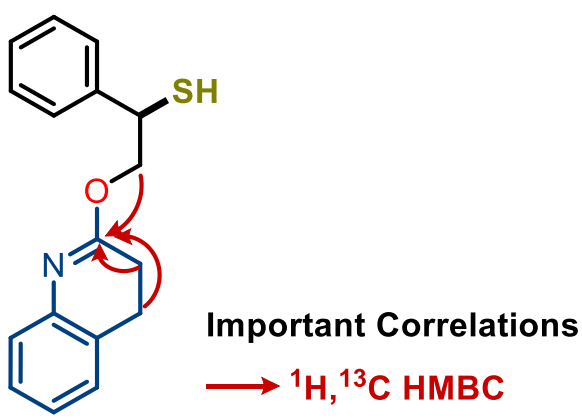

D

Table 3.4: Chemical Shifts Assignments of the D and Cross Peaks Observed in the 2DNMR Measurements

\begin{tabular}{|c|c|c|c|c|}
\hline Atom & Chemical Shift & COSY & HSQC & HMBC \\
\hline \multicolumn{5}{|l|}{$7 \mathrm{C}$} \\
\hline $\mathrm{H2}$ & 2.85 & 8 & & 9 \\
\hline $8 \mathrm{C}$ & 25.06 & & 8 & \\
\hline $\mathrm{H} 2$ & 2.44 & 7 & 8 & 9 \\
\hline $9 \mathrm{C}$ & 166.53 & & & $8,7,14^{\prime}, 14^{\prime \prime}$ \\
\hline \multicolumn{5}{|l|}{$11 \mathrm{~S}$} \\
\hline H & 2.27 & & & \\
\hline \multicolumn{5}{|l|}{120} \\
\hline $13 \mathrm{C}$ & 42.53 & & 13 & $14^{\prime}, 14^{\prime \prime}$ \\
\hline H & 4.46 & $14^{\prime \prime}, 14^{\prime}$ & 13 & $14,15,16,20$ \\
\hline $14 \mathrm{C}$ & 70.55 & & $14^{\prime}, 14^{\prime \prime}$ & 13 \\
\hline $\mathrm{H}^{\prime}$ & 4.65 & $13,14 "$ & 14 & $9,13,15$ \\
\hline H" & 4.57 & 13,14 & 14 & $9,13,15$ \\
\hline $15 \mathrm{C}$ & 140.02 & & & $14^{\prime}, 14 ", 13$ \\
\hline $16 \mathrm{C}$ & 127.67 & & & 13 \\
\hline \multicolumn{5}{|l|}{ H } \\
\hline $20 \mathrm{C}$ & 127.67 & & & 13 \\
\hline H & & & & \\
\hline
\end{tabular}




\section{$\underline{{ }^{1} \text { H NMR Spectrum }}$}

\section{8}

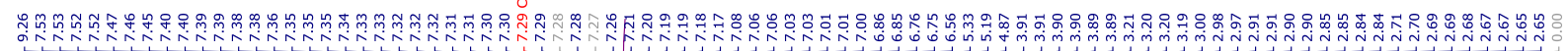

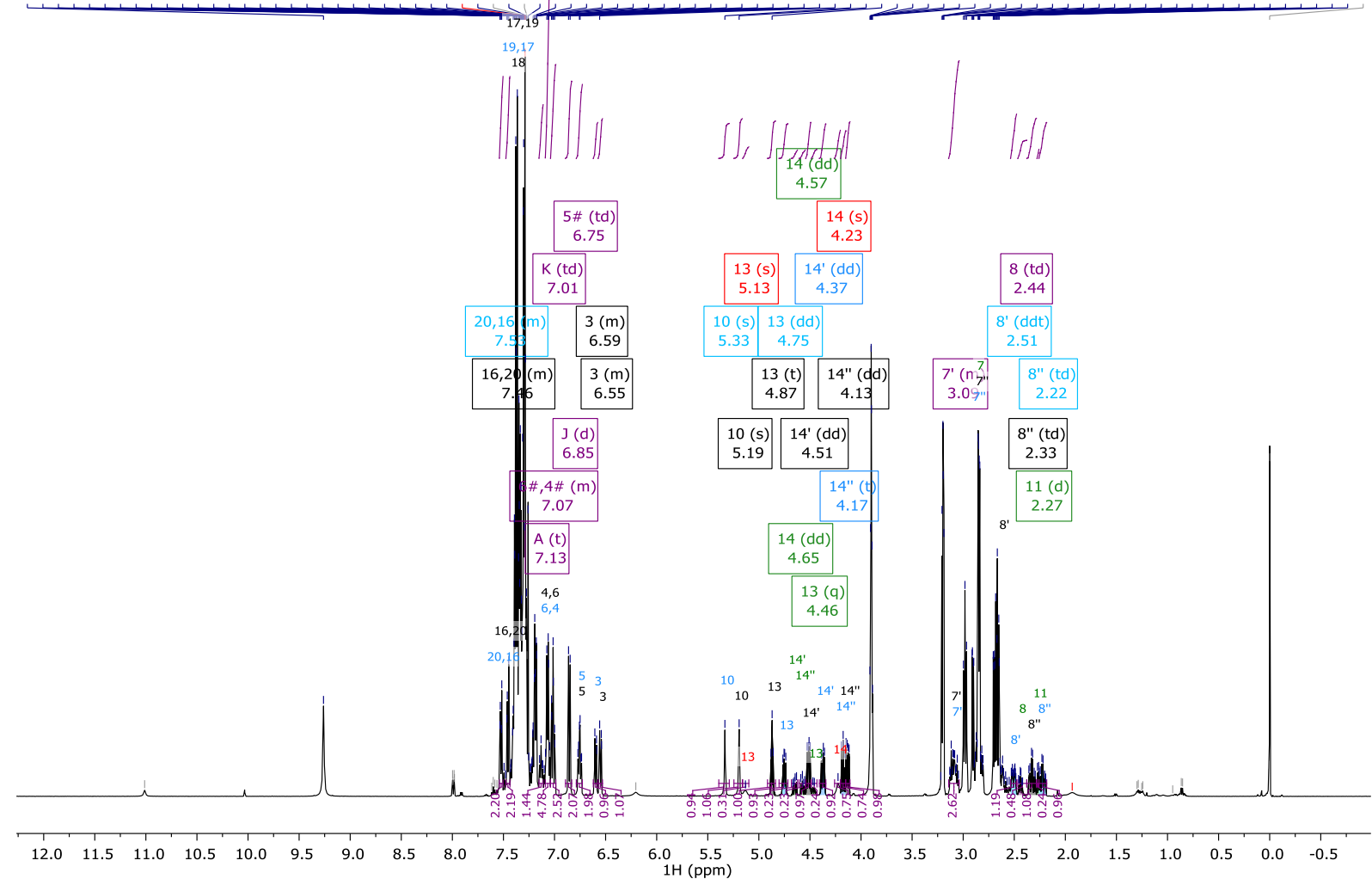

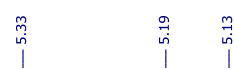

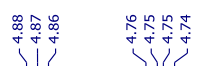

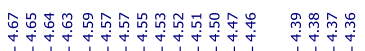

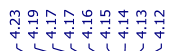
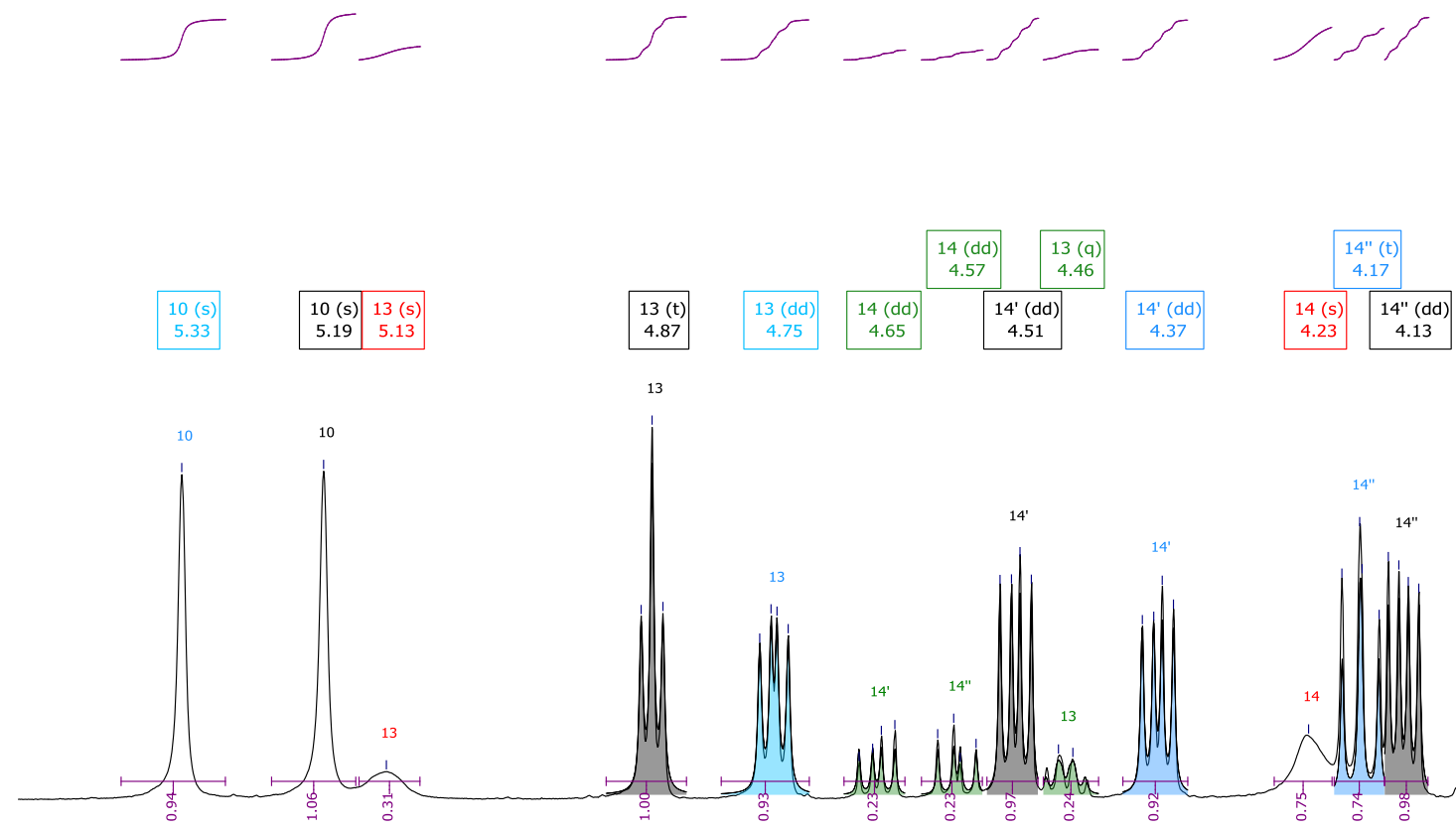

$\begin{array}{llllllllllllllllllllllllllllllllllllllll}5.45 & 5.40 & 5.35 & 5.30 & 5.25 & 5.20 & 5.15 & 5.10 & 5.05 & 5.00 & 4.95 & 4.90 & 4.85 & 4.80 & 4.75 & 4.70 & 4.65 & 4.60 & 4.55 & 4.50 & 4.45 & 4.40 & 4.35 & 4.30 & 4.25 & 4.20 & 4.15 & 4.10 & 4.05 & 4.00\end{array}$ 


\section{${ }^{13}$ C NMR Spectrum}

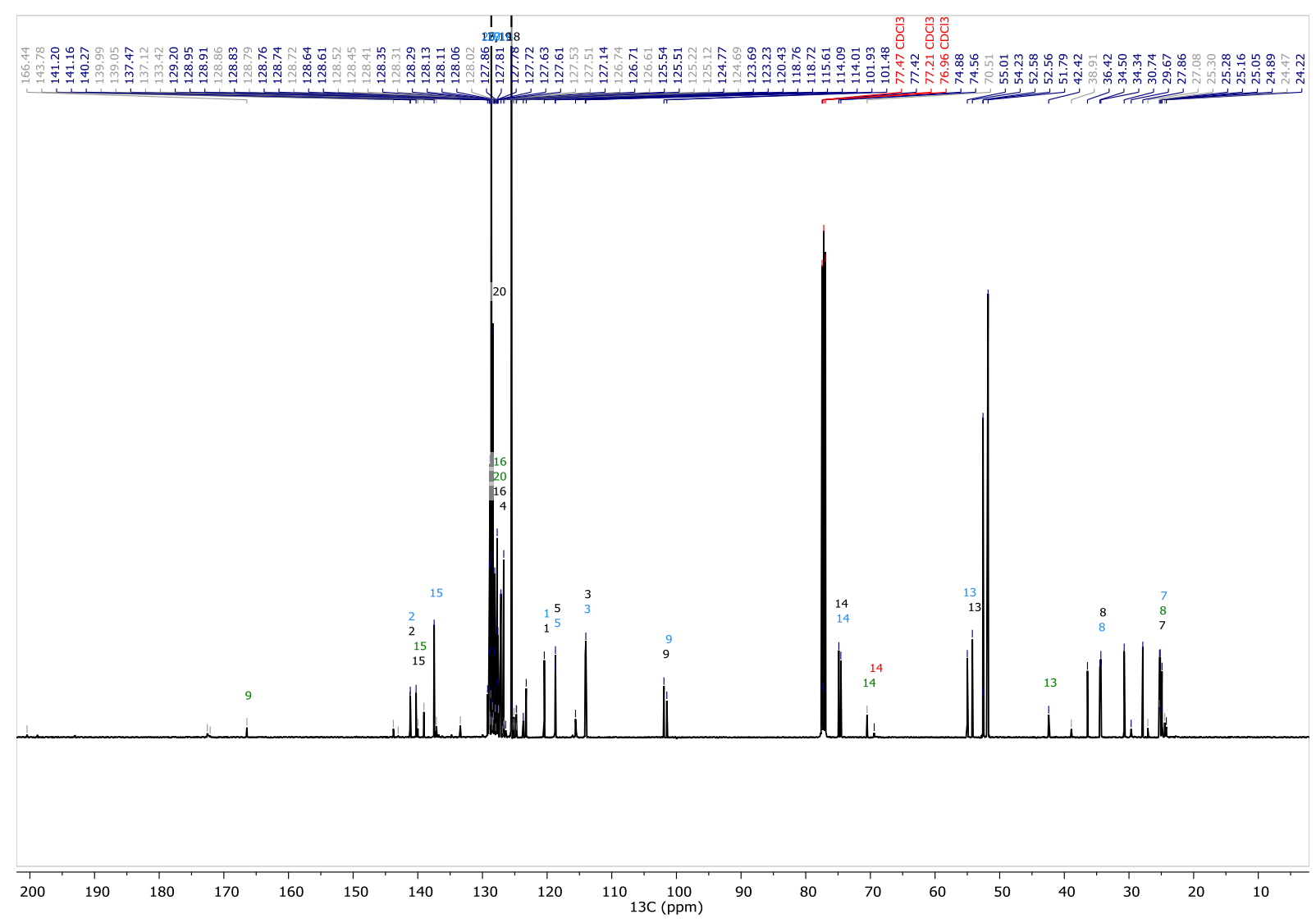




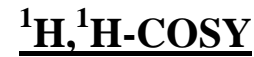

(udd) $\mathrm{HI}$

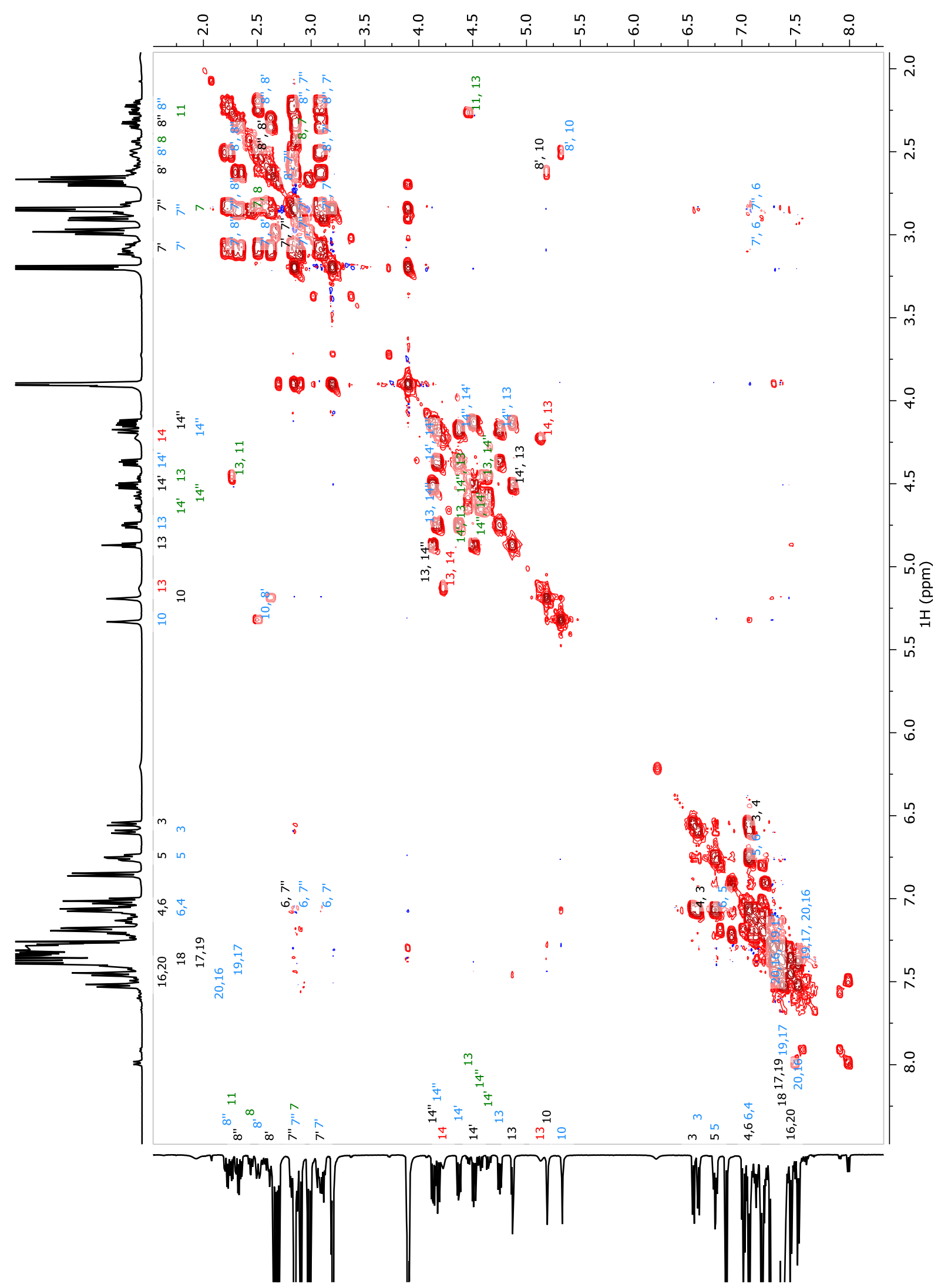




\section{$\underline{{ }^{1} \mathrm{H},{ }^{13} \mathrm{C}-\mathrm{HSQC}}$}

(udd) כعI

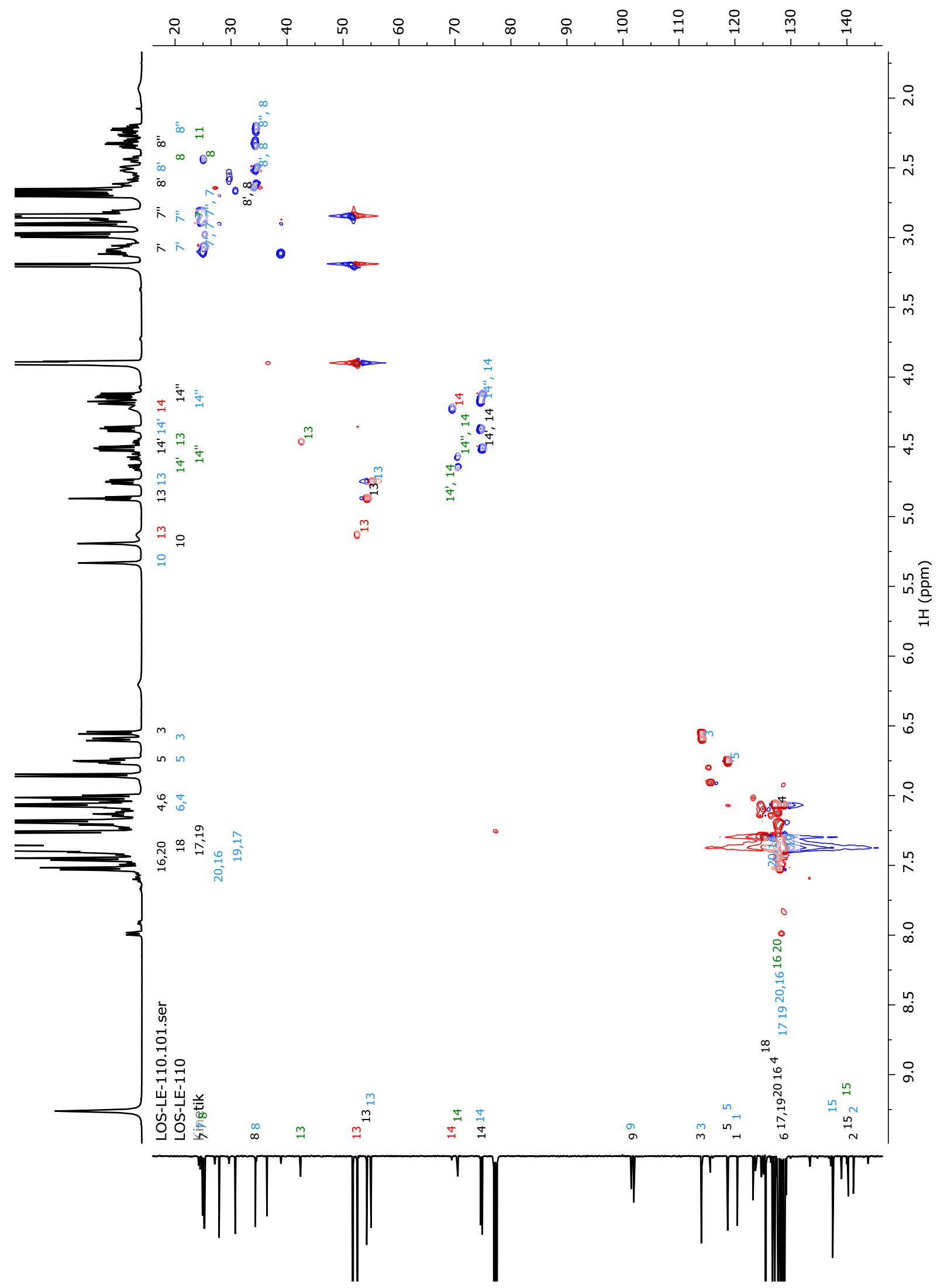




\section{$\underline{{ }^{1} \mathrm{H},{ }^{13} \mathrm{C}-\mathrm{HMBC}}$}

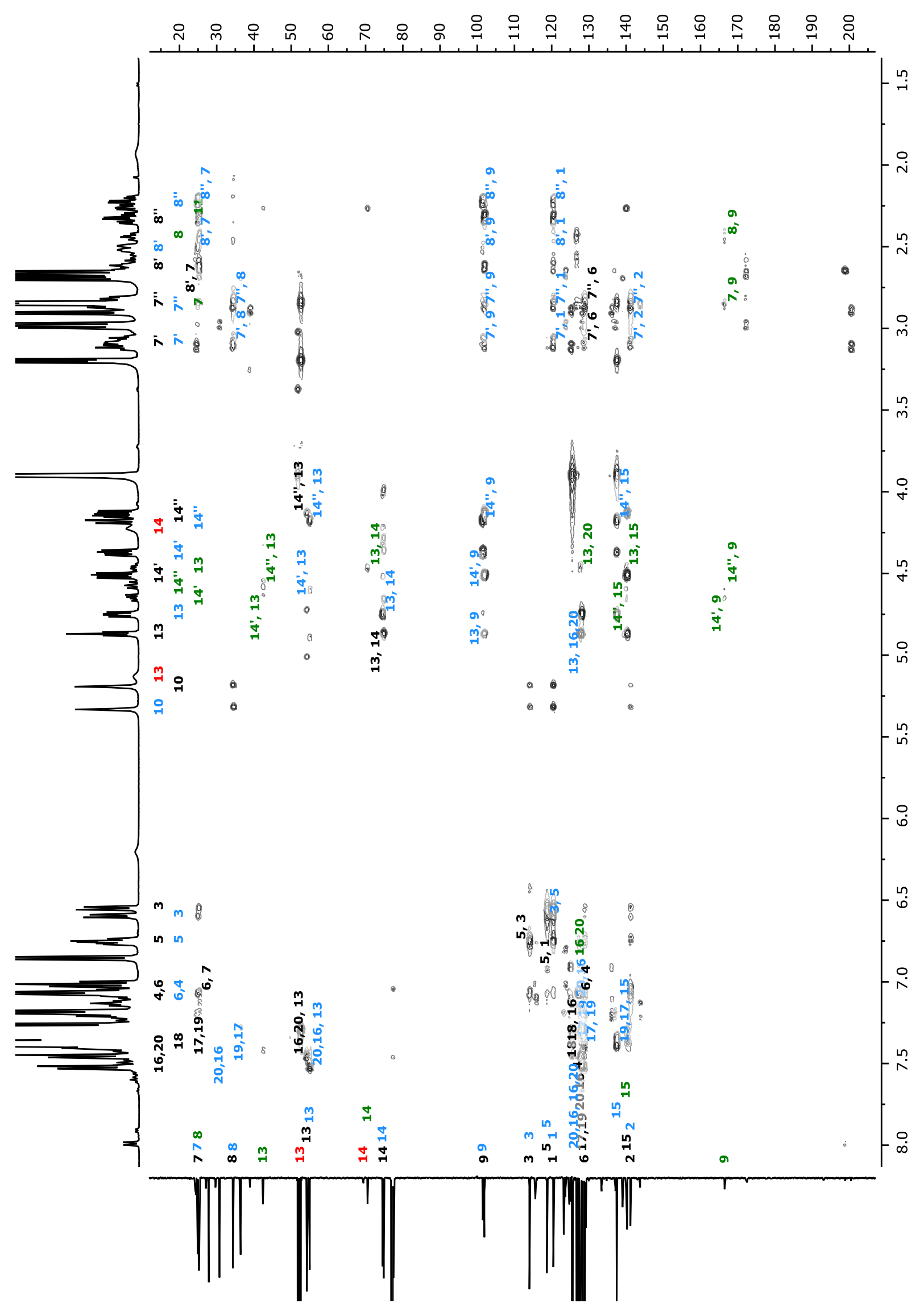



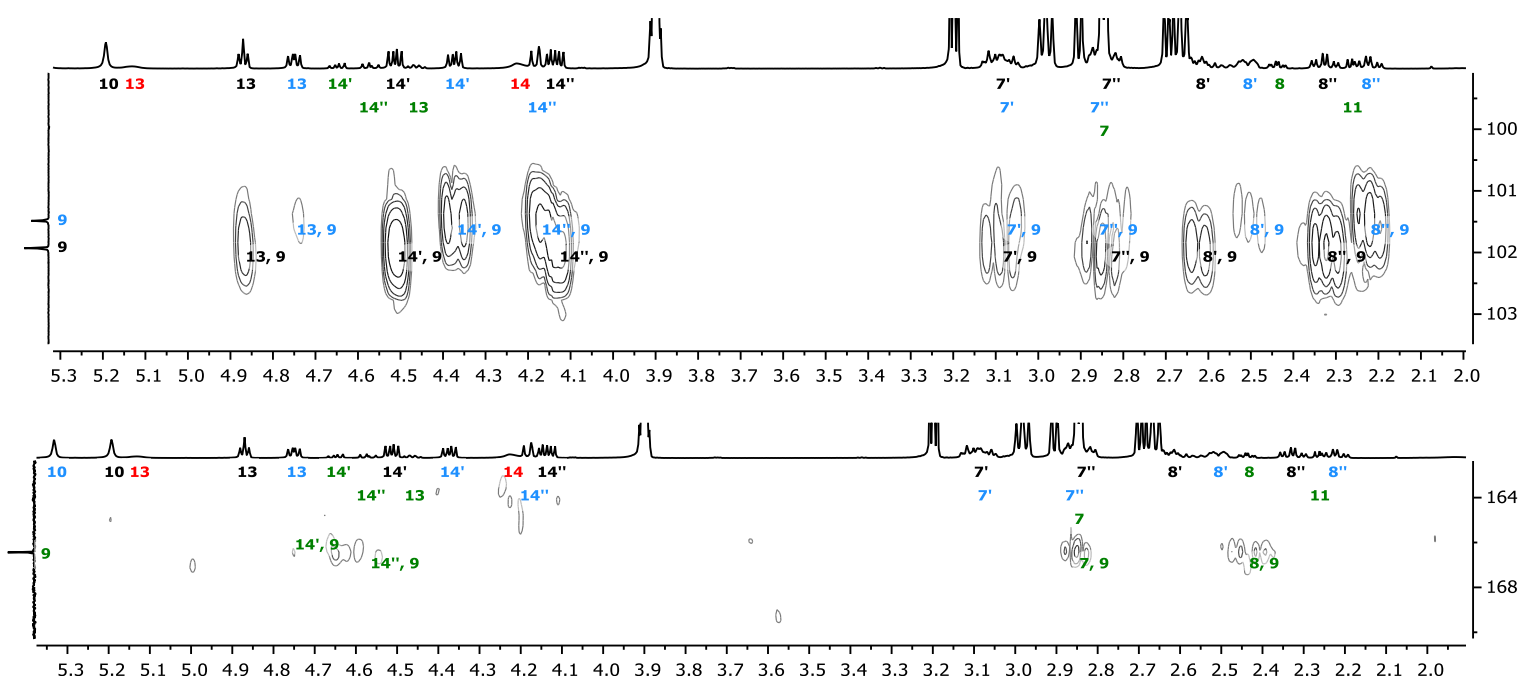

\section{$\underline{{ }^{1} \mathrm{H},{ }^{15} \mathrm{~N}-\mathrm{HMBC}}$}

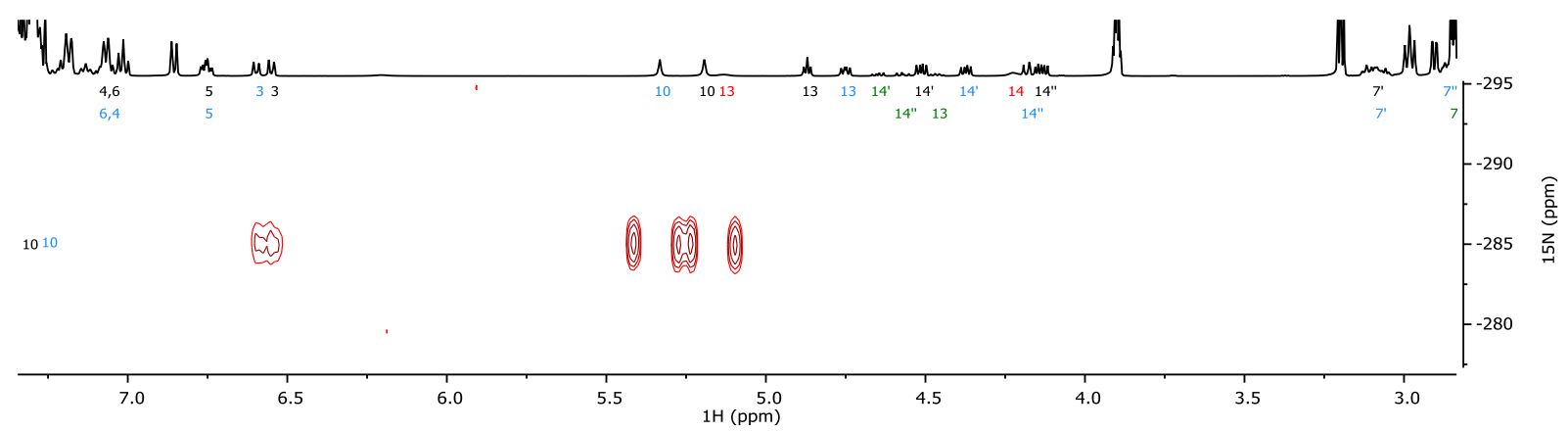




\section{$\underline{{ }^{1} \mathrm{H},{ }^{1} \mathrm{H}-\mathrm{NOESY}}$}

(udd) $\mathrm{HI}$

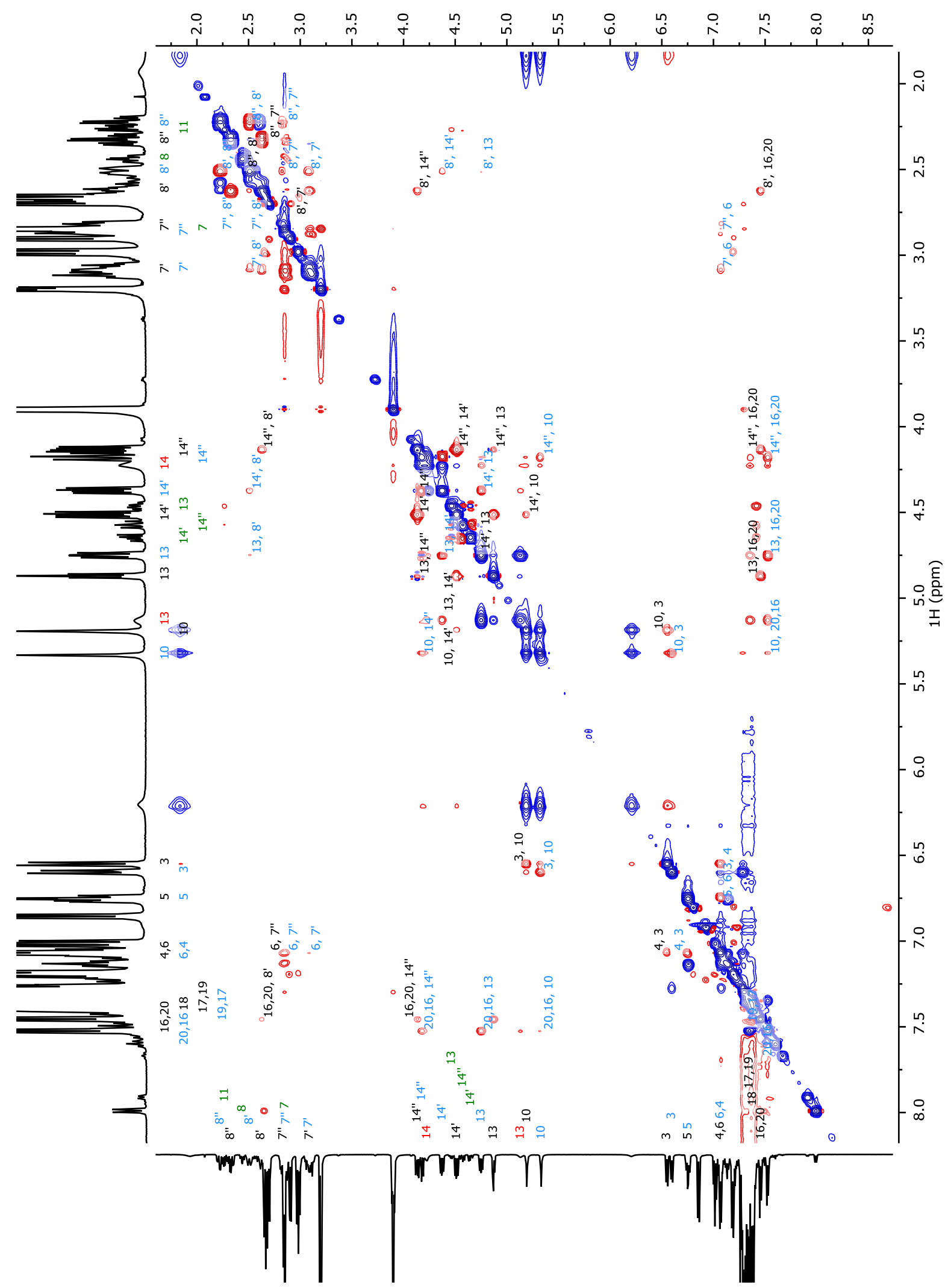




\subsection{Interconversion and Equilibrium Between the Reaction Intermediates}

During the analysis of the ${ }^{1} \mathrm{H}-{ }^{1} \mathrm{H}-\mathrm{NOESY}$ spectrum, we observed EXSY cross peaks between $\mathbf{B}$ and $\mathbf{C}$, whereas the exchange from $\mathbf{B}$ to $(R)-\mathbf{C}$ is faster than the exchange from $\mathbf{B}$ to $(S)$-C (Figure 3.3). An exchange from $\mathbf{B}$ or $\mathbf{C}$ towards $\mathbf{D}$ was not observed. The exchange between $\mathbf{B}$ and $\mathbf{C}$, which resulted in a broadening of $\mathbf{B}$ and $(R)-\mathbf{C}$ at room temperature could not be observed after a basic quench with $\mathrm{K}_{2} \mathrm{CO}_{3}$ of the reaction mixture, supporting that this equilibrium is acid catalyzed. Additionally the ratio between the intermediates changes immediately when heating from $-20{ }^{\circ} \mathrm{C}$ to $25{ }^{\circ} \mathrm{C}$, whereas it stayed constant at $-20{ }^{\circ} \mathrm{C}$ for several hours (Figure 3.4). This supports further the equilibrium between the intermediates.

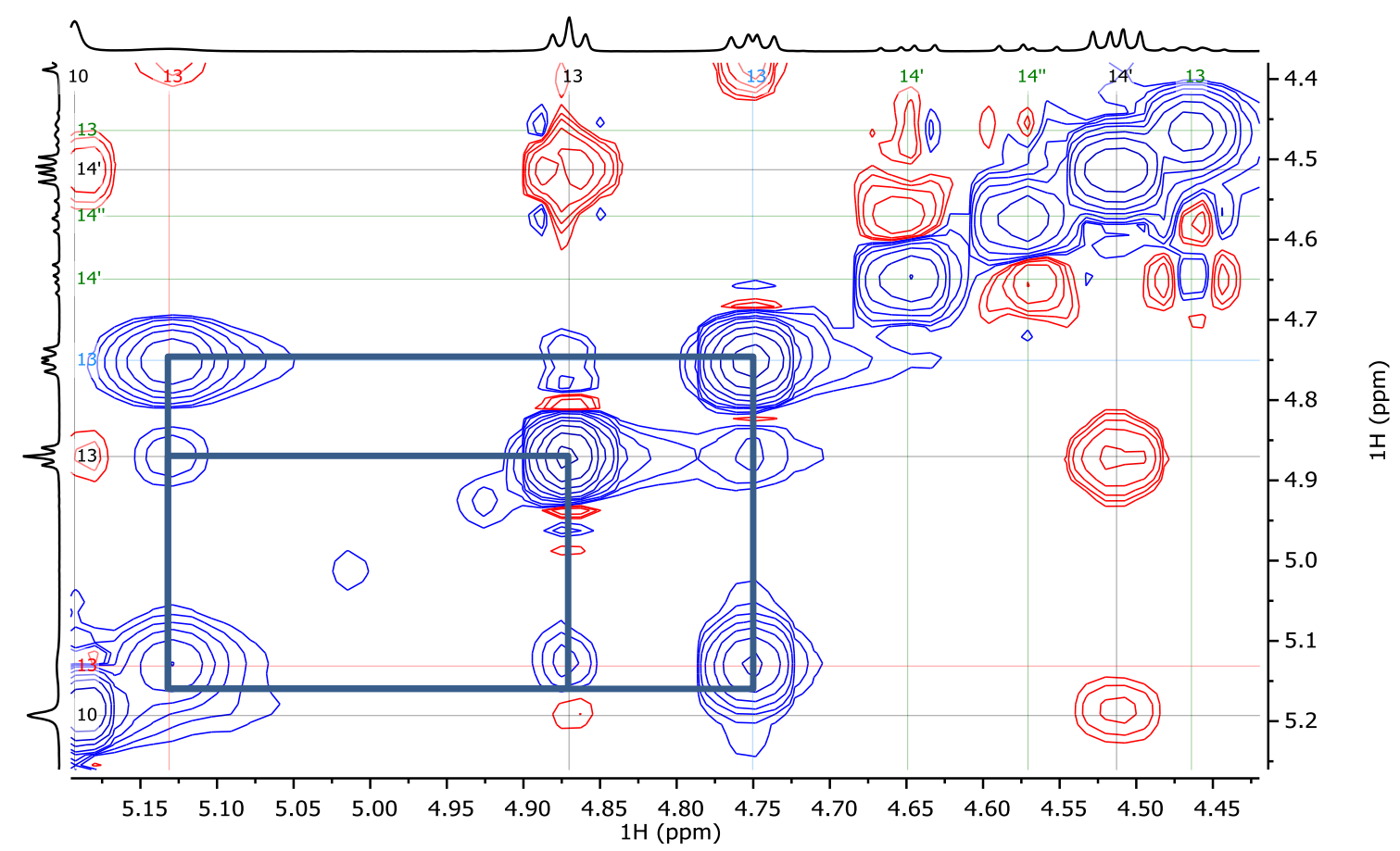

Figure 3.3: Section from the ${ }^{1} \mathrm{H},{ }^{1} \mathrm{H}-\operatorname{NOESY}\left(\tau_{\text {mix }}=1 \mathrm{~s}\right)$ that shows (blue) EXSY cross peaks between $\mathrm{B}$ and $\mathrm{C}$. 


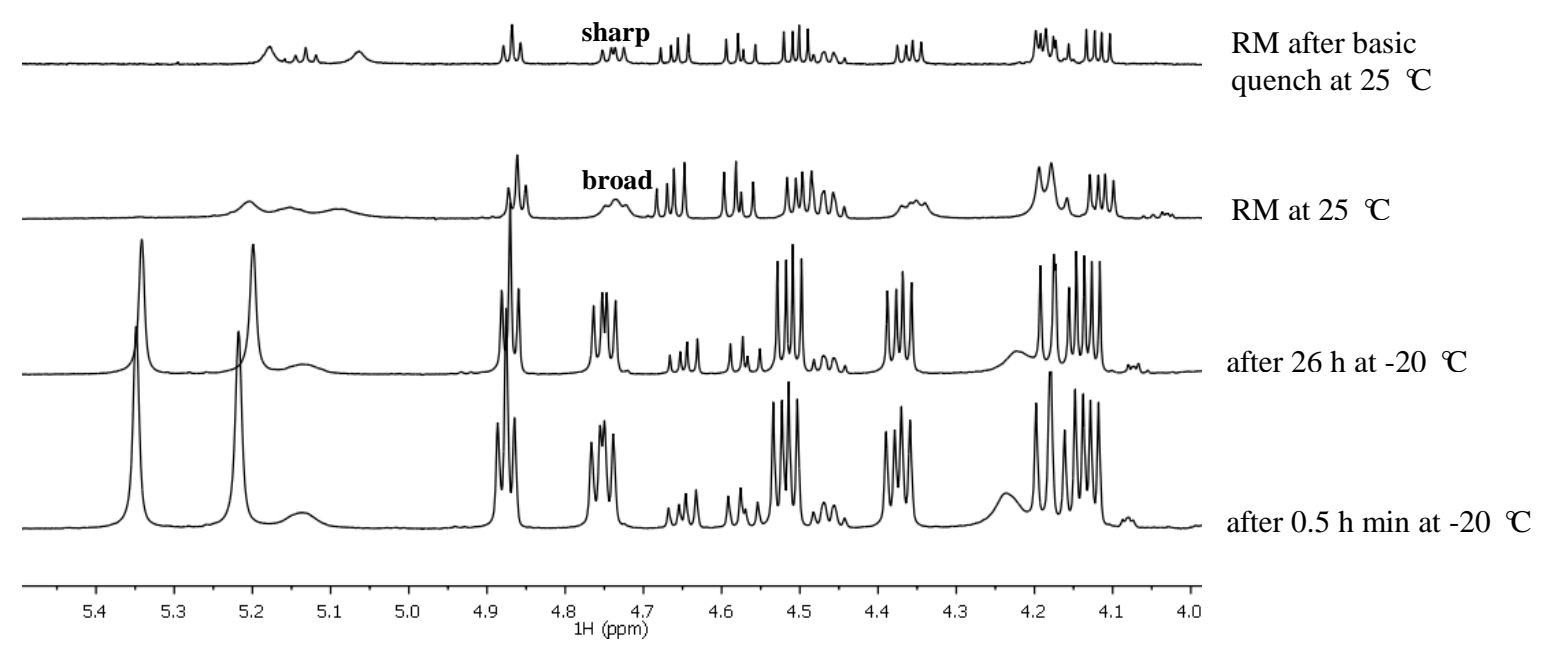

Figure 3.4: Various ${ }^{1} \mathrm{H}$ NMR spectra of the reaction mixture

\subsection{Trapping of the Reaction Intermediates}

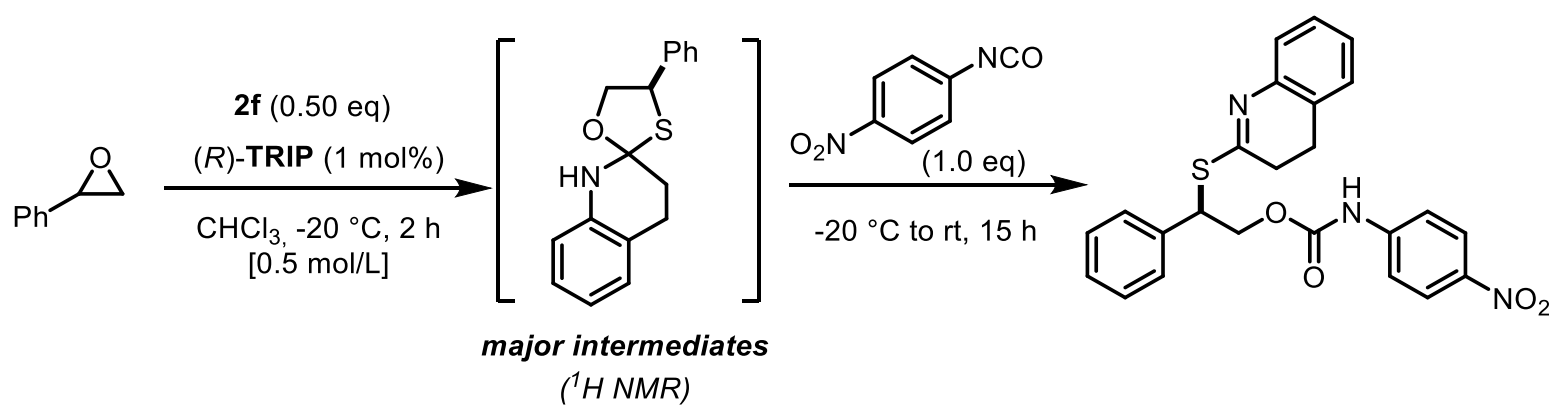

Styrene oxide 1a $(0.5 \mathrm{mmol}, 60 \mathrm{mg}, 57 \mu \mathrm{L})$ was weighed into a glass vial, and dissolved with $1 \mathrm{~mL}$ of dry $\mathrm{CHCl}_{3}$. The vial was cooled at $-20{ }^{\circ} \mathrm{C}$ for $20 \mathrm{~min}$, and then sulfur donor $\mathbf{2 f}$ ( $0.25 \mathrm{mmol}, 41 \mathrm{mg}, 0.5$ equiv) was added, followed by adding the catalyst $(R)$-TRIP (3.7 mg, $0.005 \mathrm{mmol}, 1 \mathrm{~mol} \%)$. Until the consumption of the sulfur donor $>95 \%$ ( $2 \mathrm{~h}$ ), the reaction was quenched with solid $\mathrm{K}_{2} \mathrm{CO}_{3}$, and then the isocyanate $(82 \mathrm{mg}, 0.50 \mathrm{mmol})$ was added. After 5 hours, the reaction was warmed up to room temperature and stirred for another 15 hours. The reaction mixture was centrifuged and the organic layer was subjected to column chromatography on silica gel (hexane/EtOAc 4:1 $\mathrm{Rf}=0.3$ ). The major product was isolated as a slightly yellow solid in $31 \%$ yield and identified to be the structure shown in the scheme, which was also the major product in the crude NMR. HRMS (m/z) calcd for $\mathrm{C}_{24} \mathrm{H}_{21} \mathrm{~N}_{3} \mathrm{O}_{4} \mathrm{~S}$ $[\mathrm{M}]+:$ 448.1325, found: 448.1328. The er was determined to be 96.5:3.5 (AD-3, heptane/isopropanol, 80:20, $1.0 \mathrm{~mL} / \mathrm{min}, \mathrm{t}_{\mathrm{r}}=5.9,8.1 \mathrm{~min}$ ), in good agreement with the er of 
the thiirane product, suggesting the initial opening step is the enantio-determining step. This experiment also suggests that the spiro intermediates $\mathbf{C}$ can go back to $\mathbf{B}$ and then be trapped.

\section{NMR assignment of the trapped intermediate}

18<smiles>O=C(Nc1ccc([N+](=O)[O-])cc1)OCC(SC1=Nc2ccccc2CC1)c1ccccc1</smiles>

Selected connections from 2D-NMR measurements

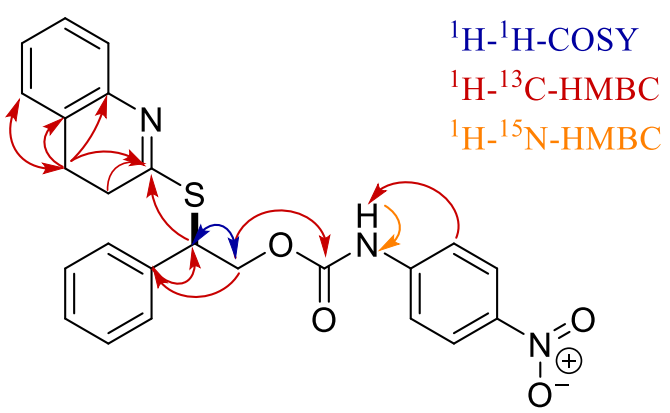

Table 3.5: Chemical Shifts Assignments of the Trapped Intermediate and Cross Peaks Observed in the 2D-NMR Measurements

\begin{tabular}{|c|c|c|c|c|c|c|c|c|c|c|c|}
\hline Atom & $\begin{array}{c}\text { Chemical } \\
\text { Shift } \\
\text { / ppm }\end{array}$ & $\mathrm{J} / \mathrm{Hz}$ & COSY & HSQC & HMBC & Atom & $\begin{array}{c}\text { Chemical } \\
\text { Shift } \\
\text { / ppm }\end{array}$ & $\mathbf{J}$ & COSY & HSQC & HMBC \\
\hline $1 \mathrm{C}$ & 128.84 & & & 1 & 3 & $17 \mathrm{C}$ & 125.39 & & & 17 & 19 \\
\hline H & 7.37 & & & 1 & 5,3 & $\mathbf{H}$ & 7.26 & & & 17 & 14,19 \\
\hline $2 \mathrm{C}$ & 128.00 & & & 2 & 6,4 & $18 \mathrm{C}$ & 127.54 & & & 18 & 20 \\
\hline H & 7.32 & & & 2 & 6,4 & $\mathbf{H}$ & 7.20 & & & 18 & 20,13 \\
\hline $3 \mathrm{C}$ & 128.84 & & & 3 & 1 & $19 \mathrm{C}$ & 125.92 & & & 19 & 20,17 \\
\hline H & 7.37 & & & 3 & 1,5 & $\mathbf{H}$ & 7.08 & & & 19 & 14,17 \\
\hline $4 \mathrm{C}$ & 128.20 & & & 4 & $2,7,6$ & $20 \mathrm{C}$ & 127.46 & & & 20 & 15,18 \\
\hline H & 7.45 & & & 4 & $2,6,7$ & \multirow[t]{2}{*}{$\mathbf{H}$} & \multirow[t]{2}{*}{7.08} & & & \multirow[t]{2}{*}{20} & 19,18 \\
\hline \multirow[t]{2}{*}{$5 \mathrm{C}$} & \multirow[t]{2}{*}{137.82} & & & & $1,3,7,8^{\prime}$, & & & & & & 13,15 \\
\hline & & & & & 8" & $21 \mathrm{C}$ & 152.26 & & & & $8^{\prime}, 8^{\prime \prime}$ \\
\hline $6 \mathrm{C}$ & 128.20 & & & 6 & $2,7,4$ & $22 \mathrm{~N}$ & -273.89 & & & & 22 \\
\hline H & 7.45 & & & 6 & $2,4,7$ & $\mathbf{H}$ & 6.87 & & & & 29,25 \\
\hline $7 \mathrm{C}$ & 45.31 & & & 7 & 8', 8", 6, 4 & $24 \mathrm{C}$ & 143.65 & & & & 26,28 \\
\hline \multirow[t]{2}{*}{$\mathbf{H}$} & \multirow[t]{2}{*}{5.51} & \multirow{3}{*}{$\begin{array}{l}6.30\left(8^{\prime}\right), \\
8.00\left(8^{\prime \prime}\right) \\
\end{array}$} & \multirow[t]{2}{*}{$8^{\prime}, 8^{\prime \prime}$} & \multirow[t]{2}{*}{7} & \multirow{2}{*}{$\begin{array}{c}8,11,5 \\
4,6\end{array}$} & $25 \mathrm{C}$ & 117.72 & & & 25 & 22,29 \\
\hline & & & & & & $\mathbf{H}$ & 7.45 & & 26 & 25 & 29,27 \\
\hline $8 \mathrm{C}$ & 67.09 & & & $8^{\prime}, 8^{\prime \prime}$ & 7 & $26 \mathrm{C}$ & 125.14 & & & 26 & 28 \\
\hline $\mathbf{H}^{\prime}$ & 4.76 & $6.30(7)$ & 7 & 8 & $21,7,5$ & H & 8.16 & & 25 & 26 & 28,24 \\
\hline $\mathbf{H}^{\prime \prime}$ & 4.71 & $8.00(7)$ & 7 & 8 & $21,7,5$ & $27 \mathrm{C}$ & 143.00 & & & & 29,25 \\
\hline $11 \mathrm{C}$ & 166.39 & & & & $7,16,15$ & $28 \mathrm{C}$ & 125.14 & & & 28 & 26 \\
\hline $13 \mathrm{C}$ & 143.92 & & & & $15,20,18$ & H & 8.16 & & 29 & 28 & 26,24 \\
\hline \multirow[t]{2}{*}{$14 \mathrm{C}$} & \multirow[t]{2}{*}{126.56} & & & \multirow{2}{*}{\multicolumn{2}{|c|}{$\begin{array}{c}16,15 \\
19,17 \\
\end{array}$}} & $29 \mathrm{C}$ & 117.72 & & & 29 & 22,25 \\
\hline & & & & & & $\mathbf{H}$ & 7.45 & & 28 & 29 & 25,27 \\
\hline $15 \mathrm{C}$ & 24.38 & & & 15 & 16,20 & & & & & & \\
\hline H2 & 2.78 & & 16 & 15 & $\begin{array}{c}16,14, \\
20,13,11\end{array}$ & & & & & & \\
\hline $16 \mathrm{C}$ & 29.79 & & & 16 & 15 & & & & & & \\
\hline H2 & 2.47 & & 15 & 16 & $15,11,14$ & & & & & & \\
\hline
\end{tabular}




\section{$\underline{{ }^{1} \text { H NMR Spectrum }}$}

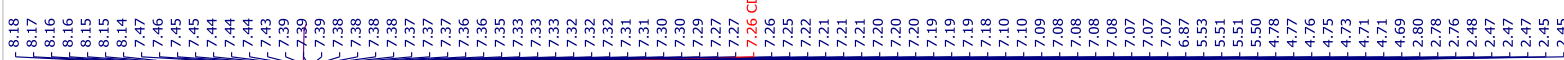

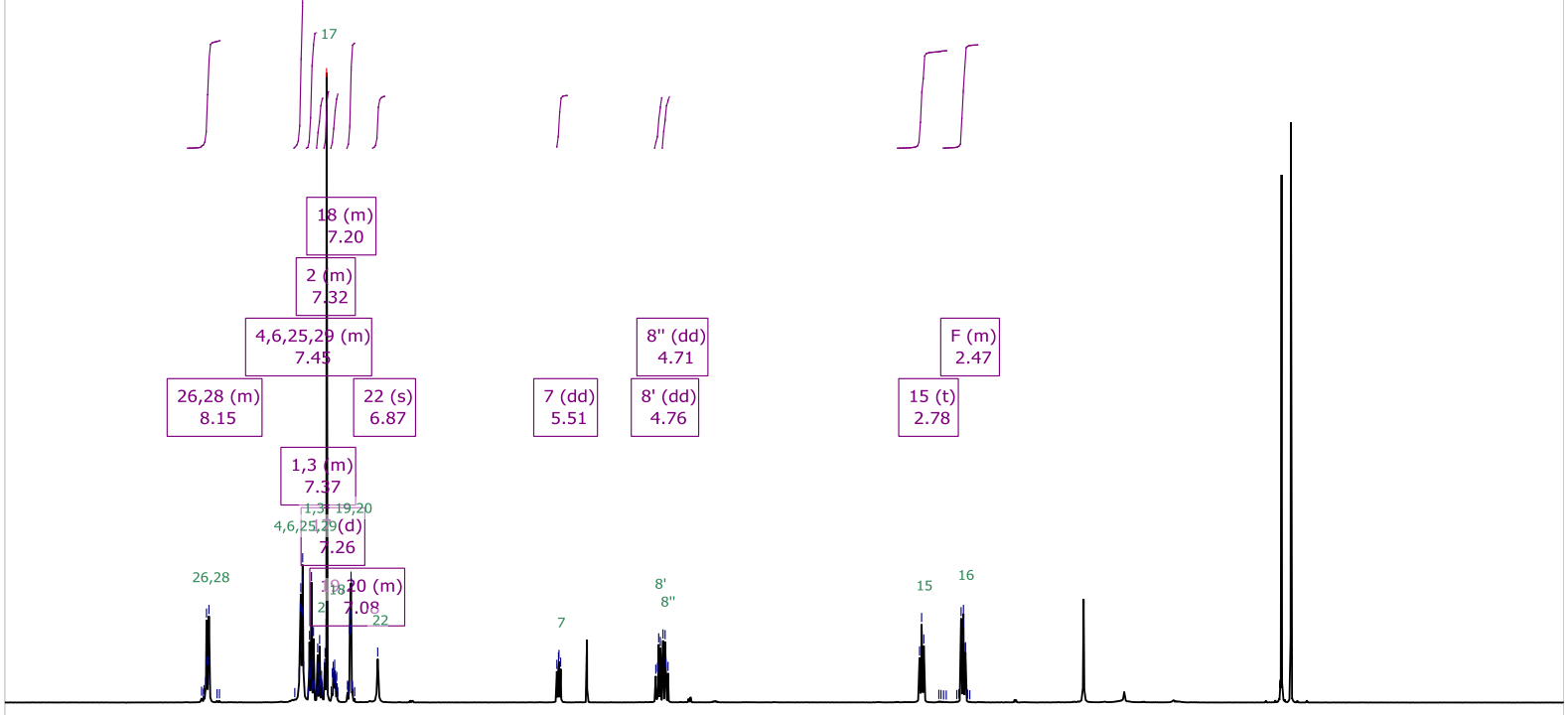

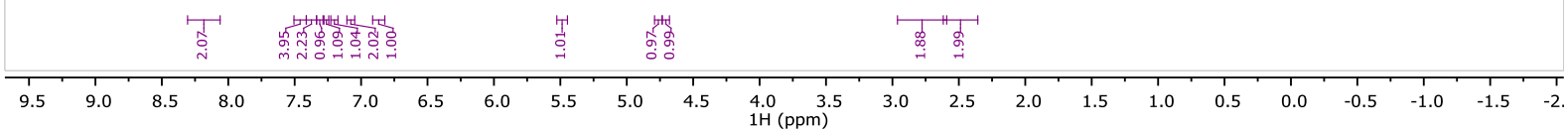

\section{$\underline{{ }^{13} \text { C NMR Spectrum }}$}

\begin{tabular}{|c|c|c|c|c|}
\hline 商 & 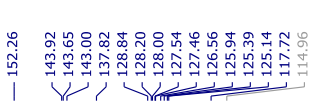 & 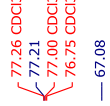 & $\begin{array}{l}\vec{m} \\
\dot{y} \\
\mid\end{array}$ & 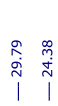 \\
\hline
\end{tabular}

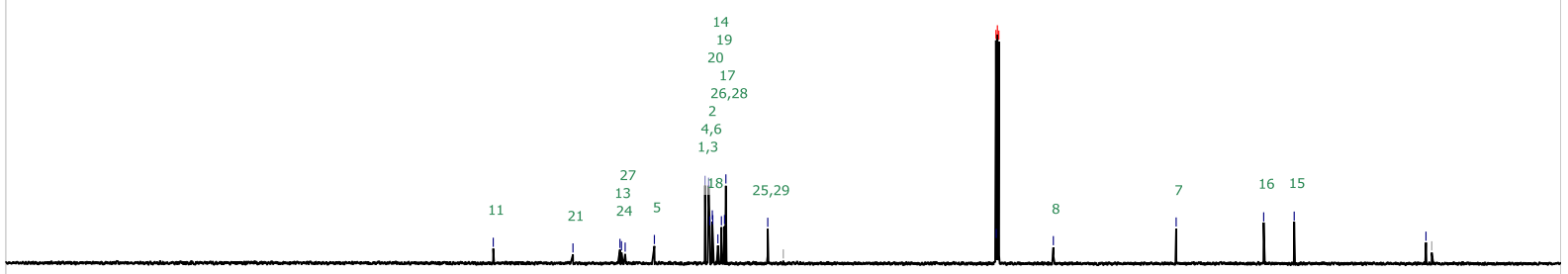

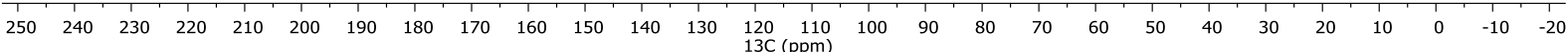




\section{$\underline{{ }^{1} \mathrm{H}-{ }^{1} \mathrm{H}-\mathrm{COSY}}$}

(mdd) $\mathrm{HI}$

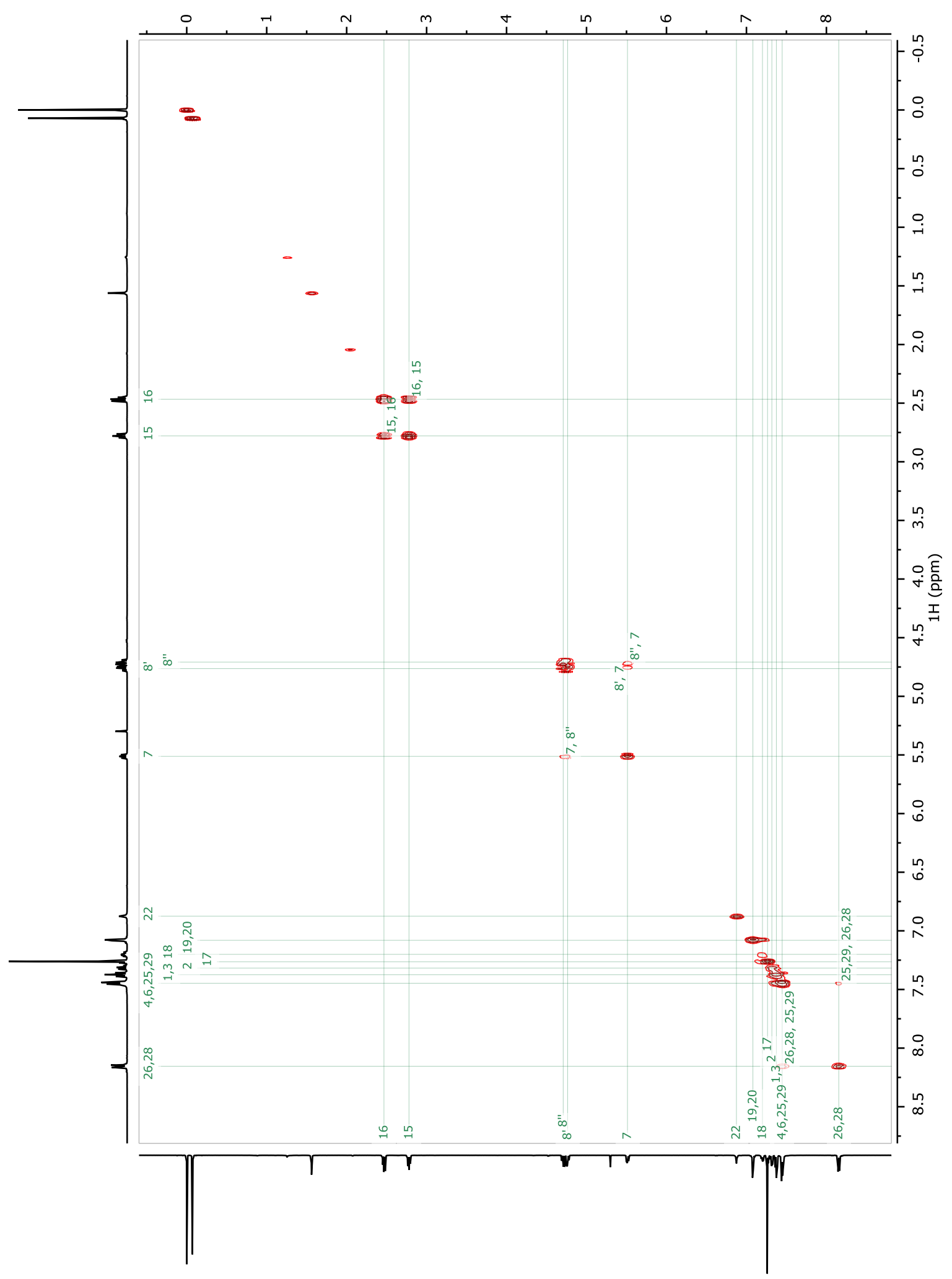


$\underline{{ }^{1} \mathrm{H}-{ }^{13} \mathrm{C}-\mathrm{HSQC}}$

(wdd) ગદ

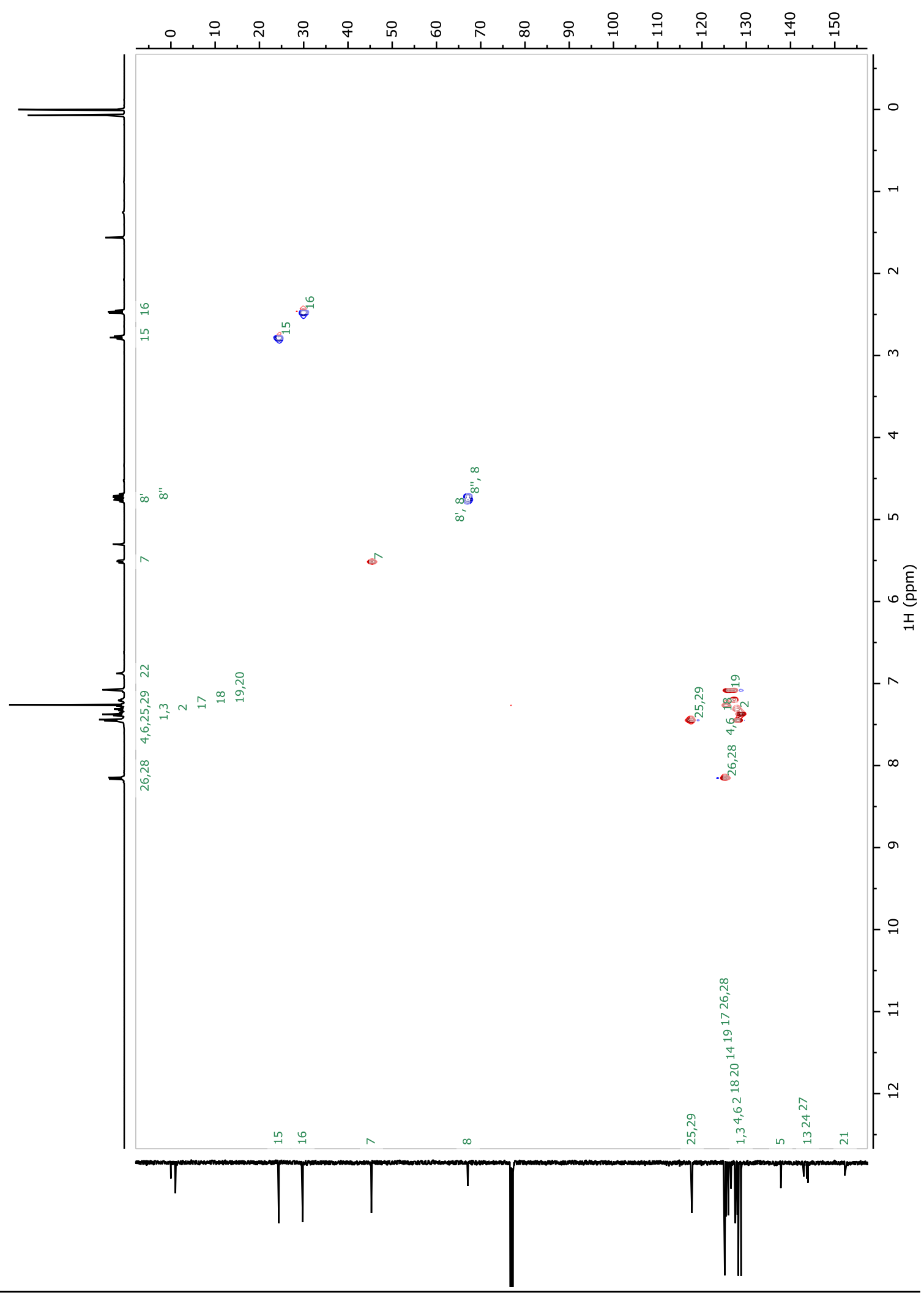




\section{${ }^{1} \mathrm{H}-{ }^{13} \mathrm{C}-\mathrm{HMBC}$}

(udd) כعI

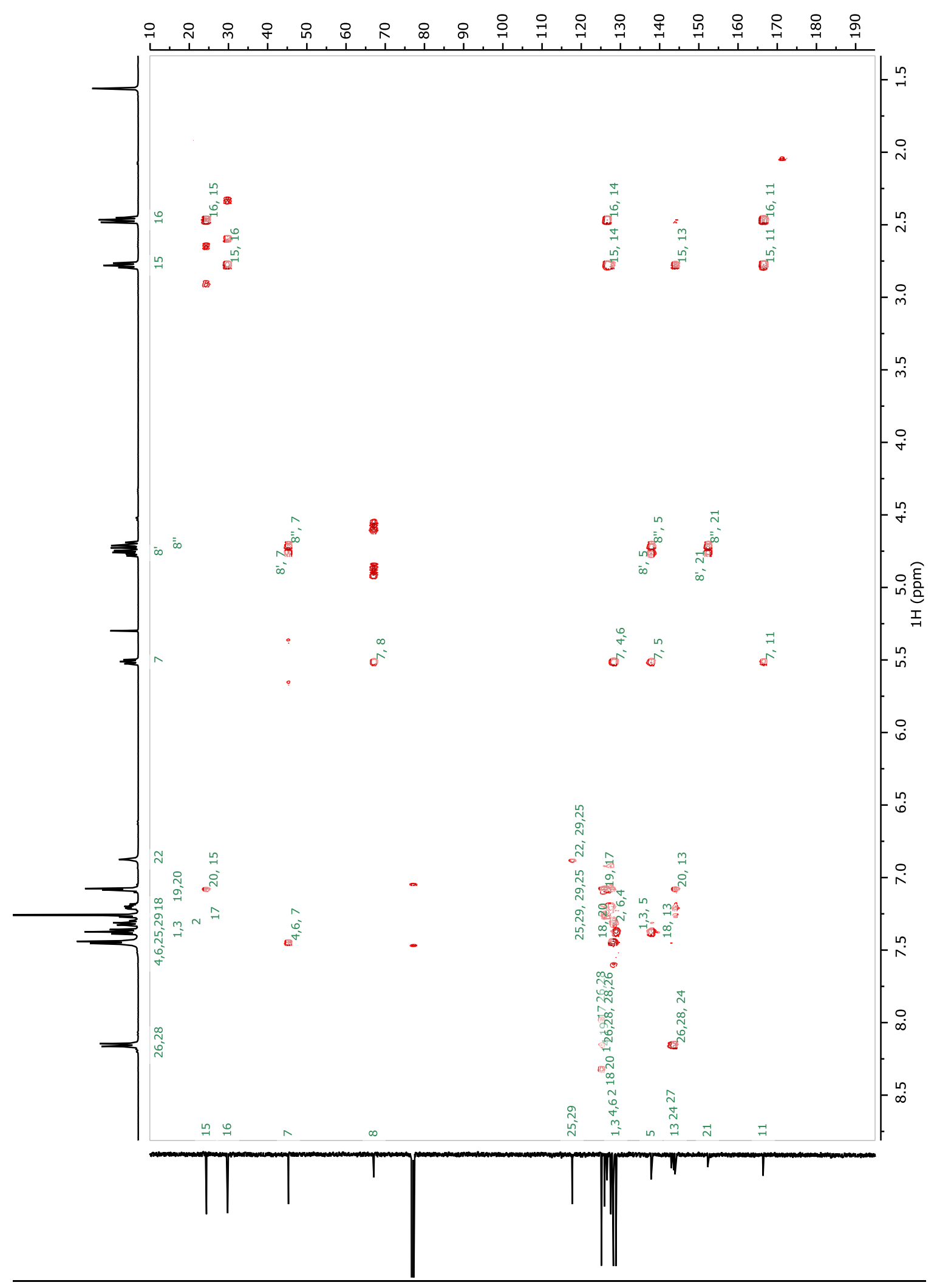


$\underline{{ }^{1} \mathrm{H}^{-15} \mathrm{~N}-\mathrm{HMBC}}$

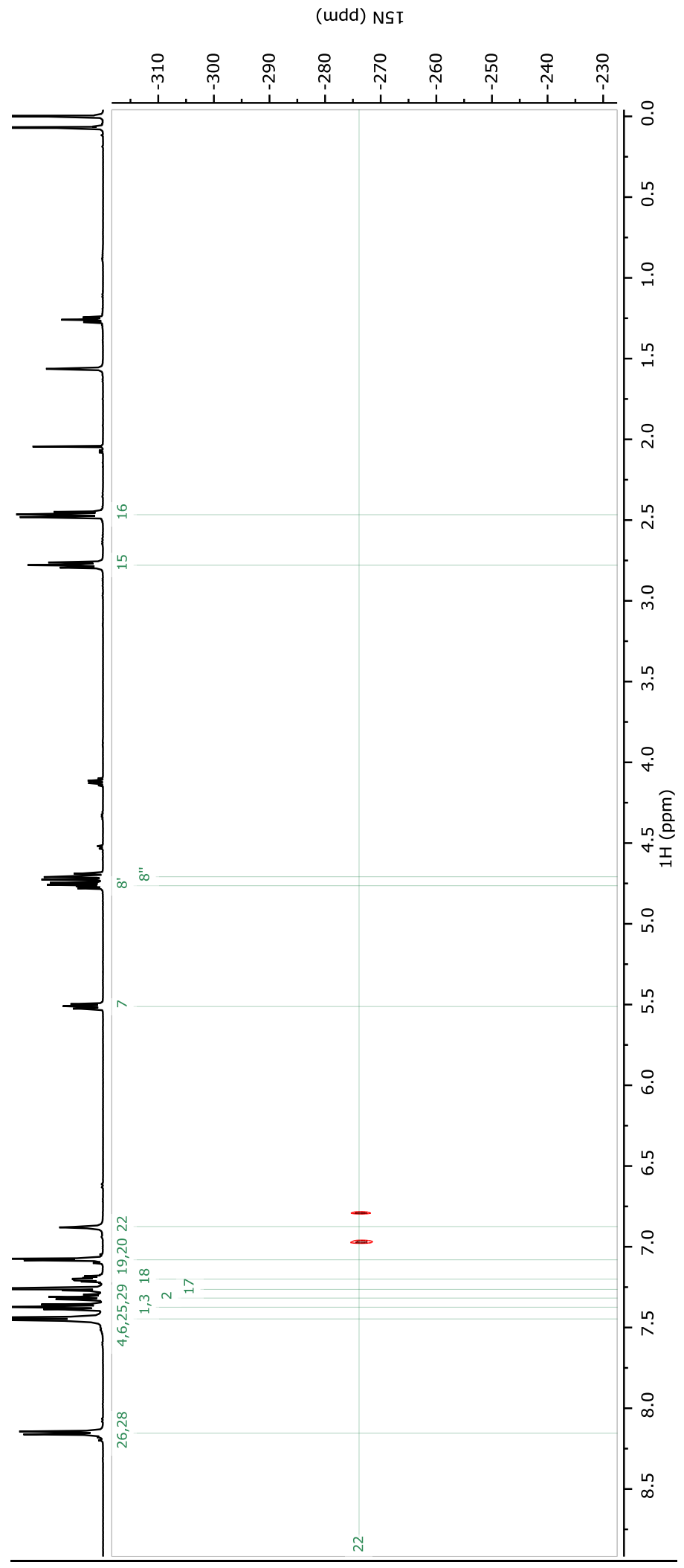




\section{Preparation of Starting Epoxides and Thiolactam $2 \mathrm{f}$}

Epoxides 1a, 1d, 1e and 1o are commercially available and were used for the reactions without further purification. Other known epoxides were prepared following literature procedures, by epoxidizing the olefins with $\mathrm{mCPBA}$ in $\mathrm{DCM}$ at $0{ }^{\circ} \mathrm{C}(\mathbf{1 b}, \mathbf{1 c}, \mathbf{1 f}, \mathbf{1 g} \boldsymbol{\&} \mathbf{1 h})$, or through the Corey-Chaykovsky epoxidation from the corresponding aldehydes (1i-m). The racemic thiiranes were prepared according to the asymmetric procedure by using (R/S)-TRIP at a $0.01 \%$ catalyst loading at room temperature.

Most of the thioureas and thioamides used in this work are commercially available or can be readily prepared with the known methods from amides using $\mathrm{P}_{2} \mathrm{~S}_{5}$ or Lawesson's reagent as a thionating agent. ${ }^{5}$ Thiolactam $\mathbf{2 f}$ was prepared according to the literature procedure ${ }^{5}$ from the corresponding commercially available lactam.<smiles>O=C1CCc2ccccc2N1</smiles>

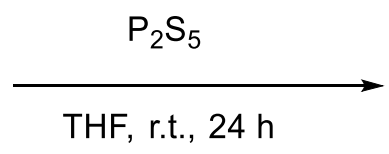<smiles>S=C1CCc2ccccc2N1</smiles>

A mixture of 3,4-dihydroquinolin-2-one $(1.47 \mathrm{~g}, 10 \mathrm{mmol})$ and $\mathrm{P}_{2} \mathrm{~S}_{5}(3.00 \mathrm{~g}, 13.5 \mathrm{mmol})$ in THF (100 mL) was allowed to stir for $20 \mathrm{~min}$ at room temperature. Sodium bicarbonate (1.68 $\mathrm{g}, 20 \mathrm{mmol}$ ) was added portionwise to the above mixture and the reaction mixture was allowed to stir for $24 \mathrm{~h}$ at room temperature (monitored by TLC, then by ${ }^{1} \mathrm{H}$ NMR, >95\% conv.). The reaction mixture was then filtered and the excess of THF was removed under reduced pressure. Purification by column on silica gel (EtOAc/Hexane, 1:4) and then recrystallization from hexane/DCM afforded the pure product as slightly yellow crystals (1.51 g, 92\%). ${ }^{1} \mathbf{H}$ NMR (500 MHz, $\left.\mathrm{CDCl}_{3}\right): \delta 9.66$ (s, br, 1H), 7.24-7.18 (m, 2H), $7.08(\mathrm{td}, J=7.5$, $1.1 \mathrm{~Hz}, 1 \mathrm{H}), 6.85(\mathrm{~d}, J=7.9 \mathrm{~Hz}, 1 \mathrm{H}), 3.11(\mathrm{~m}, 2 \mathrm{H}), 2.89(\mathrm{t}, J=7.5 \mathrm{~Hz}, 2 \mathrm{H}) ;{ }^{13} \mathbf{C} \mathbf{N M R}(125$ $\left.\mathrm{MHz}, \mathrm{CDCl}_{3}\right): \delta 200.6,136.2,128.4,127.8,125.2,124.9,115.5,38.9,24.6 ; \mathbf{H R M S}(\mathrm{m} / \mathrm{z})$ calcd for $\mathrm{C}_{9} \mathrm{H}_{9} \mathrm{NS}[\mathrm{M}]+:$ 164.0529, found: 164.0528 .

\section{Catalytic Enantioselective Conversion of Epoxides to Thiiranes}

Typical procedure: Styrene oxide $1 \mathrm{a}(0.5 \mathrm{mmol}, 60 \mathrm{mg}, 57 \mu \mathrm{L})$ was weighed into a glass vial, and dissolved with $5 \mathrm{~mL}$ of dry $\mathrm{CHCl}_{3}$. The vial was cooled at $-20{ }^{\circ} \mathrm{C}$ for $20 \mathrm{~min}$, and then 
sulfur donor $2 \mathbf{f}(0.25 \mathrm{mmol}, 41 \mathrm{mg}, 0.5$ equiv) was added, followed by the addition of the catalyst $(R)$-TRIP $(0.37 \mathrm{mg}, 0.0005 \mathrm{mmol}, 0.1 \mathrm{~mol} \%$, or its stock solution). Until the complete consumption of the sulfur donor, the reaction was then warmed up to room temperature and stirred for another five hours (to ensure all the intermediates were converted to the product, substrates $\mathbf{1 l}, \mathbf{1 m}, \mathbf{1 0}$ and $\mathbf{1 p}$ took 24 hours). The crude ${ }^{1} \mathrm{H}$ NMR indicated an almost 1:1 ratio of the epoxide and thiirane product and both products in around $50 \%$ NMR yields (with 4-bromonitrobenzene as an internal standard). The reaction was then quenched with $\mathrm{Na}_{2} \mathrm{CO}_{3}$, diluted with $20 \mathrm{~mL}$ of DCM, washed with water three times, and then dried and concentrated to $1 \mathrm{~mL}$, which was subjected to column chromatography on silica gel (5 g, eluted with hexane with $0-5 \% \mathrm{Et}_{2} \mathrm{O}$ ). The pure epoxide and thiirane product were obtained as a colorless liquid upon the removal of the eluent under reduced pressure $\left(400 \mathrm{mbar}\right.$, in $40{ }^{\circ} \mathrm{C}$ water bath, 20-30 min), and kept in the freezer $\left(-20^{\circ} \mathrm{C}\right)$.

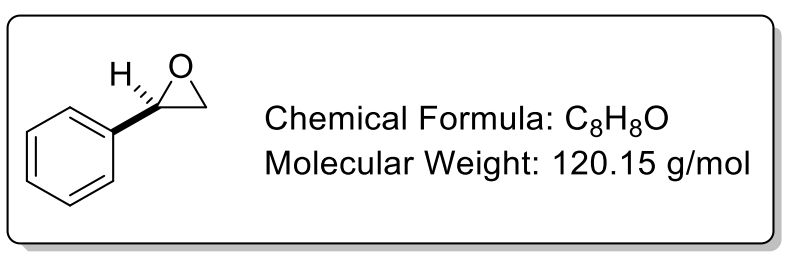

(R)-1a: ${ }^{6}$ Colorless liquid, $40 \%$ yield; ${ }^{1} \mathbf{H}$ NMR $\left(500 \mathrm{MHz}, \mathrm{CDCl}_{3}\right): \delta 7.36-7.30(\mathrm{~m}, 5 \mathrm{H}), 3.87(\mathrm{dd}, 1 \mathrm{H}, J=4.0$, $2.6 \mathrm{~Hz}$,), $3.15(\mathrm{dd}, J=5.5,2.0 \mathrm{~Hz}, 1 \mathrm{H}), 2.80(\mathrm{dd}, J=5.4,2.6 \mathrm{~Hz}, 1 \mathrm{H}) ;[\alpha]_{\mathrm{D}}{ }^{25}:-22.4^{\circ}\left(\mathrm{c}=0.5, \mathrm{CHCl}_{3}\right), \mathrm{Lit}^{6}[\alpha]_{\mathrm{D}}{ }^{25}$ : $-24^{\circ}\left(\mathrm{c}=1, \mathrm{CHCl}_{3}, \mathrm{R}\right.$-configuration, $>99 \%$ ee). The enantiomeric ratio (97:3 er) was determined by chiral HPLC analysis using an IC-3 column: heptane: $i-\mathrm{PrOH} 99: 1,0.5 \mathrm{~mL} / \mathrm{min}, 205 \mathrm{~nm}, \tau 1=8.5 \mathrm{~min}, \tau 2=9.8 \mathrm{~min}$.

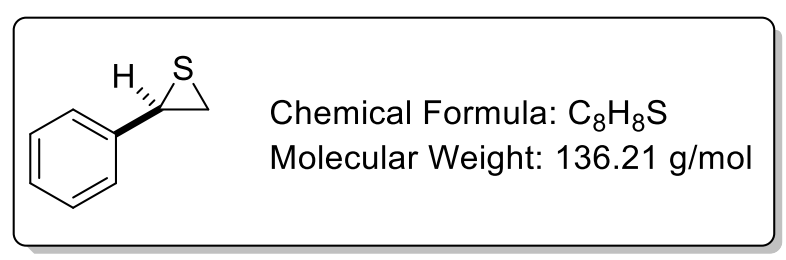

(R)-3a: $:{ }^{7}$ Colorless liquid, 47\% yield; ${ }^{1} \mathbf{H}$ NMR $\left(500 \mathrm{MHz}, \mathrm{CDCl}_{3}\right): \delta 7.31-7.22(\mathrm{~m}, 5 \mathrm{H}), 3.88(\mathrm{t}, J=6.1 \mathrm{~Hz}, 1 \mathrm{H})$, $2.85(\mathrm{dd}, J=6.5,1.5 \mathrm{~Hz}, 1 \mathrm{H}), 2.64(\mathrm{dd}, J=5.7,1.5 \mathrm{~Hz}, 1 \mathrm{H}) ;{ }^{13} \mathbf{C} \mathbf{N M R}\left(125 \mathrm{MHz}, \mathrm{CDCl}_{3}\right): \delta 139.1,128.5$, 127.6, 126.7, 36.1, 27.2; HRMS (m/z) calcd for $\mathrm{C}_{8} \mathrm{H}_{8} \mathrm{~S}[\mathrm{M}]+:$ : 136.0347, found: 136.0345 . $[\alpha]_{\mathrm{D}}{ }^{25}:-28.2^{\circ}(\mathrm{c}=1.0$, $\left.\mathrm{CH}_{2} \mathrm{Cl}_{2}\right) \cdot[\alpha]_{\mathrm{D}}^{25}:-29.3^{\circ}(\mathrm{c}=1.0$, heptane $)$. Lit. $^{7}[\alpha]_{\mathrm{D}}^{25}:+29.2^{\circ}(\mathrm{c}=1.17$, heptane, S-, $93.5 \%$ ee $)$. The enantiomeric ratio (96:4 er) was determined by chiral GC analysis using a Hydrodex- $\beta$-TBDAc column $(0.4 \mathrm{~mm}$ $\mathrm{x} 25 \mathrm{~m}$ ): $100^{\circ} \mathrm{C}$ for $40 \mathrm{~min}, \tau 1=29.4 \mathrm{~min}, \tau 2=30.7 \mathrm{~min}$. 


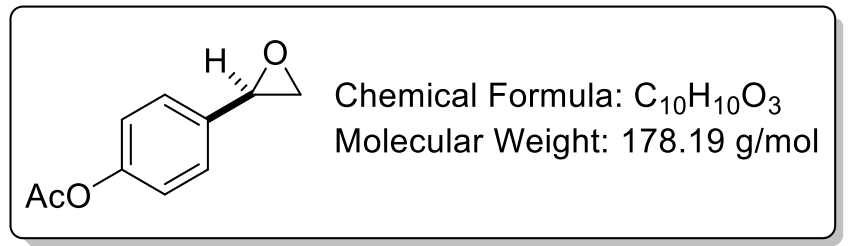

(R)-1b: Colorless liquid, $38 \%$ yield; ${ }^{1} \mathbf{H}$ NMR $\left(500 \mathrm{MHz}, \mathrm{CDCl}_{3}\right): \delta 7.28(\mathrm{dt}, J=8.5,2.3 \mathrm{~Hz}, 2 \mathrm{H}), 7.07(\mathrm{dt}, J=$ 8.5, $2.3 \mathrm{~Hz}, 2 \mathrm{H}), 3.87(\mathrm{dd}, J=4.0,2.6 \mathrm{~Hz}, 1 \mathrm{H}), 3.14(\mathrm{dd}, J=5.6,4.0 \mathrm{~Hz}, 1 \mathrm{H}), 2.78(\mathrm{dd}, J=5.5,2.6 \mathrm{~Hz}, 1 \mathrm{H})$, $2.30(\mathrm{~s}, 3 \mathrm{H}) ;[\alpha]_{\mathrm{D}}^{25}:-30.4^{\circ}\left(\mathrm{c}=0.5, \mathrm{CHCl}_{3}\right)$. The enantiomeric ratio $(97.5: 2.5 \mathrm{er})$ was determined by chiral HPLC analysis using an IC-3 column: heptane $/ i-\mathrm{PrOH} 95: 5,1.0 \mathrm{~mL} / \mathrm{min}, 205 \mathrm{~nm}, \tau 1=12.9 \mathrm{~min}, \tau 2=15.8 \mathrm{~min}$.

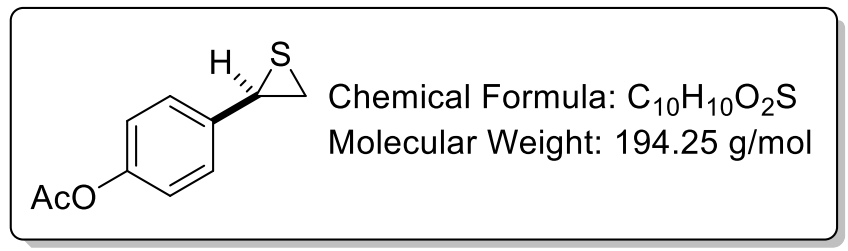

(R)-3b: White solid, 46\% yield; ${ }^{1} \mathbf{H}$ NMR $\left(500 \mathrm{MHz}, \mathrm{CD}_{2} \mathrm{Cl}_{2}\right): \delta 7.29(\mathrm{dt}, J=8.6,2.4 \mathrm{~Hz}, 2 \mathrm{H}), 7.01(\mathrm{dt}, J=8.6$, $2.4 \mathrm{~Hz}, 2 \mathrm{H}), 3.90(\mathrm{t}, J=6.1 \mathrm{~Hz}, 1 \mathrm{H}), 2.88(\mathrm{dd}, J=6.6,1.6 \mathrm{~Hz}, 1 \mathrm{H}), 2.63(\mathrm{dd}, J=5.6,1.6 \mathrm{~Hz}, 1 \mathrm{H}), 2.26(\mathrm{~s}, 3 \mathrm{H})$; ${ }^{13} \mathbf{C}$ NMR $\left(125 \mathrm{MHz}, \mathrm{CD}_{2} \mathrm{Cl}_{2}\right): \delta 169.8,150.5,137.3,128.1,122.2,35.7,27.7,21.3$; HRMS (m/z) calcd for $\mathrm{C}_{10} \mathrm{H}_{10} \mathrm{O}_{2} \mathrm{~S}[\mathrm{M}]+:$ : 194.0400 , found: $194.0402 .[\alpha]_{\mathrm{D}}^{25}:+36.0^{\circ}\left(\mathrm{c}=0.5, \mathrm{CHCl}_{3}\right)$. The enantiomeric ratio (95.5:4.5 er) was determined by chiral HPLC analysis using an IC-3 column: heptane $/ i-\mathrm{PrOH}$ 95:5, $1.0 \mathrm{~mL} / \mathrm{min}, 205 \mathrm{~nm}$, $\tau 1=7.3 \mathrm{~min}, \tau 2=8.0 \mathrm{~min}$.

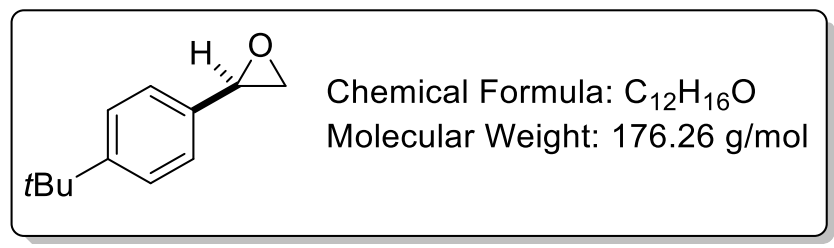

(R)-1c: ${ }^{8}$ Colorless liquid, 34\% yield; ${ }^{1} \mathbf{H}$ NMR $\left(500 \mathrm{MHz}, \mathrm{CDCl}_{3}\right): \delta 7.38(\mathrm{dt}, J=8.4,2.1 \mathrm{~Hz}, 2 \mathrm{H}), 7.22(\mathrm{dt}, J=$ 8.4, 2.1 Hz, 2H), $3.84(\mathrm{dd}, J=4.0,2.6 \mathrm{~Hz}, 1 \mathrm{H}), 3.13(\mathrm{dd}, J=5.6,4.0 \mathrm{~Hz}, 1 \mathrm{H}), 2.82(\mathrm{dd}, J=5.6,2.6 \mathrm{~Hz}, 1 \mathrm{H})$, $1.31(\mathrm{~s}, 9 \mathrm{H}) \cdot[\alpha]_{\mathrm{D}}^{25}:-18.8^{\circ}\left(\mathrm{c}=1.0, \mathrm{CHCl}_{3}\right)$. The enantiomeric ratio $(99.7: 0.3)$ was determined by chiral HPLC analysis using an OJ-H column: heptane $/ i$-PrOH 99:1, $0.5 \mathrm{~mL} / \mathrm{min}, 230 \mathrm{~nm}, \tau 1=15.0 \mathrm{~min}, \tau 2=16.8 \mathrm{~min}$.

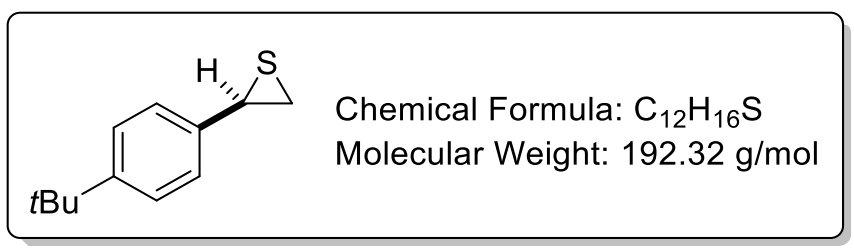


(R)-3c: Colorless liquid, 48\% yield; ${ }^{1} \mathbf{H}$ NMR $\left(500 \mathrm{MHz}, \mathrm{CD}_{2} \mathrm{Cl}_{2}\right): \delta 7.24(\mathrm{dt}, J=8.6,2.0 \mathrm{~Hz}, 2 \mathrm{H}), 7.12(\mathrm{dt}, J=$ 8.6, $2.0 \mathrm{~Hz}, 2 \mathrm{H}), 3.80(\mathrm{t}, J=6.1 \mathrm{~Hz}, 1 \mathrm{H}), 2.76(\mathrm{dd}, J=6.6,1.6 \mathrm{~Hz}, 1 \mathrm{H}), 2.58(\mathrm{dd}, J=5.6,1.6 \mathrm{~Hz}, 1 \mathrm{H}), 1.21(\mathrm{~s}$, 9H); ${ }^{13} \mathbf{C}$ NMR (125 MHz, $\left.\mathrm{CD}_{2} \mathrm{Cl}_{2}\right): \delta 151.2,136.6,126.8,125.9,36.3,34.9,31.4,27.3$. HRMS (m/z) calcd for $\mathrm{C}_{12} \mathrm{H}_{16} \mathrm{~S}[\mathrm{M}]+:$ : 192.0973 , found: $192.0972 .[\alpha]_{\mathrm{D}}^{25}:-3.9^{\circ}\left(\mathrm{c}=1.0, \mathrm{CH}_{2} \mathrm{Cl}_{2}\right)$. The enantiomeric ratio (93.5:6.5) was determined by chiral HPLC analysis using an AD-3R column: water/MeCN 30:70, $0.5 \mathrm{~mL} / \mathrm{min}, 230 \mathrm{~nm}, \tau 1=$ $12.6 \min , \tau 2=16.0 \mathrm{~min}$.

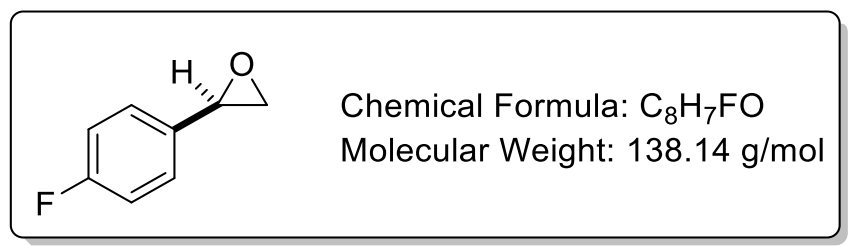

(R)-1d: ${ }^{9}$ Colorless liquid, $35 \%$ yield; ${ }^{1} \mathbf{H}$ NMR $\left(500 \mathrm{MHz}, \mathrm{CDCl}_{3}\right): \delta$ 7.30-7.20 (m, 2H), 7.06-7.02 (m, 2H), $3.85(\mathrm{dd}, J=4.1,2.6 \mathrm{~Hz}, 1 \mathrm{H}), 3.14(\mathrm{dd}, J=5.6,4.0 \mathrm{~Hz}, 1 \mathrm{H}), 2.77(\mathrm{dd}, J=5.4,2.6 \mathrm{~Hz}, 1 \mathrm{H}) .[\alpha]_{\mathrm{D}}^{25}:-24.6^{\circ}(\mathrm{c}=$ 1.0, $\mathrm{CHCl}_{3}$ ). Lit. ${ }^{9}[\alpha]_{\mathrm{D}}{ }^{20}:+15.6^{\circ}\left(\mathrm{c}=0.97, \mathrm{CHCl}_{3}, \mathrm{~S}\right.$-configuration, $96 \%$ ee). The enantiomeric ratio (97:3 er) was determined by chiral HPLC analysis using an IC-3 column: heptane/ $i$-PrOH 99:1, 0.5 mL/min, $205 \mathrm{~nm}, \tau 1=7.6$ $\min , \tau 2=8.1 \min$.

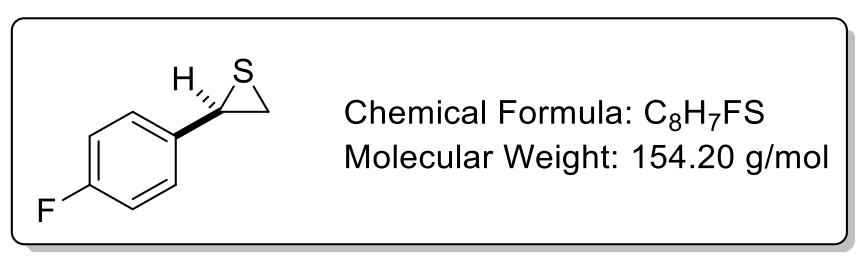

(R)-3d: Colorless liquid, $48 \%$ yield; ${ }^{1} \mathbf{H}$ NMR $\left(500 \mathrm{MHz}, \mathrm{CDCl}_{3}\right): \delta$ 7.20-7.16 (m, 2H), 6.94-6.89 (m, $\left.2 \mathrm{H}\right), 3.81$ $(\mathrm{t}, J=6.1 \mathrm{~Hz}, 1 \mathrm{H}), 2.78(\mathrm{dd}, J=6.6,1.6 \mathrm{~Hz}, 1 \mathrm{H}), 2.52(\mathrm{dd}, J=5.6,1.6 \mathrm{~Hz}, 1 \mathrm{H}) ;{ }^{13} \mathbf{C} \mathbf{N M R}\left(125 \mathrm{MHz}, \mathrm{CD}_{2} \mathrm{Cl}_{2}\right)$ : $\delta 162.0\left(\mathrm{~d}, J_{\mathrm{C}-\mathrm{F}}=245.2 \mathrm{~Hz}\right), 135.6\left(\mathrm{~d}, J_{\mathrm{C}-\mathrm{F}}=3.1 \mathrm{~Hz}\right), 128.7\left(\mathrm{~d}, J_{\mathrm{C}-\mathrm{F}}=7.8 \mathrm{~Hz}\right), 115.7\left(\mathrm{~d}, J_{\mathrm{C}-\mathrm{F}}=21.9 \mathrm{~Hz}\right), 35.7$, 27.6; ${ }^{19}$ F NMR $\left(282 \mathrm{MHz}, \mathrm{CD}_{2} \mathrm{Cl}_{2}\right): \delta$-115.6. HRMS (m/z) calcd for $\mathrm{C}_{8} \mathrm{H}_{7} \mathrm{FS}[\mathrm{M}]+:$ : 154.0251 , found: 154.0252 . $[\alpha]_{\mathrm{D}}{ }^{25}:-23.8^{\circ}\left(\mathrm{c}=1.0, \mathrm{CH}_{2} \mathrm{Cl}_{2}\right)$. The enantiomeric ratio $(95: 5 \mathrm{er})$ was determined by chiral $\mathrm{GC}$ analysis using a Hydrodex- $\beta$-TBDAc column $(0.4 \mathrm{~mm} \times 25 \mathrm{~m}): 100{ }^{\circ} \mathrm{C}$ for $60 \mathrm{~min}, \tau 1=53.6 \mathrm{~min}, \tau 2=56.3 \mathrm{~min}$.

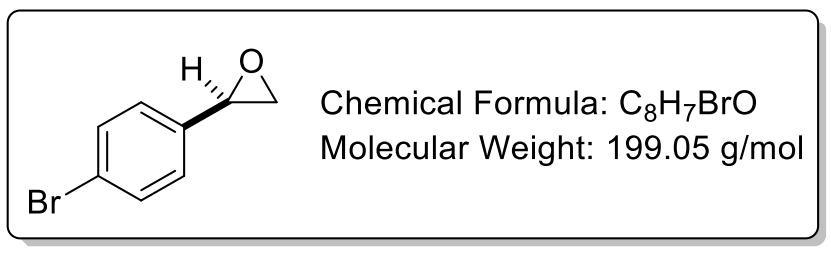

(R)-1e: ${ }^{6}$ Colorless liquid, $40 \%$ yield; ${ }^{1} \mathbf{H}$ NMR $\left(500 \mathrm{MHz}, \mathrm{CDCl}_{3}\right): \delta 7.47(\mathrm{dt}, J=8.4,2.2 \mathrm{~Hz}, 2 \mathrm{H}), 7.15(\mathrm{dt}, J=$ 8.4, $2.2 \mathrm{~Hz}, 2 \mathrm{H}), 3.83(\mathrm{dd}, J=4.0,2.6 \mathrm{~Hz}, 1 \mathrm{H}), 3.15(\mathrm{dd}, J=5.4,4.0 \mathrm{~Hz}, 1 \mathrm{H}), 2.75(\mathrm{dd}, J=5.4,2.5 \mathrm{~Hz}, 1 \mathrm{H})$. $[\alpha]_{\mathrm{D}}^{25}:-17.6^{\circ}\left(\mathrm{c}=1.0, \mathrm{CHCl}_{3}\right)$. Lit. $^{6}[\alpha]_{\mathrm{D}}{ }^{24}:+20.5^{\circ}\left(\mathrm{c}=1.27, \mathrm{CHCl}_{3}\right.$, S-configuration, $>99 \%$ ee $)$. The 
enantiomeric ratio (97.5:2.5 er) was determined by chiral HPLC analysis using an OJ-H column: heptane/i-PrOH 99:1, $1.0 \mathrm{~mL} / \mathrm{min}, 220 \mathrm{~nm}, \tau 1=9.8 \mathrm{~min}, \tau 2=10.6 \mathrm{~min}$.

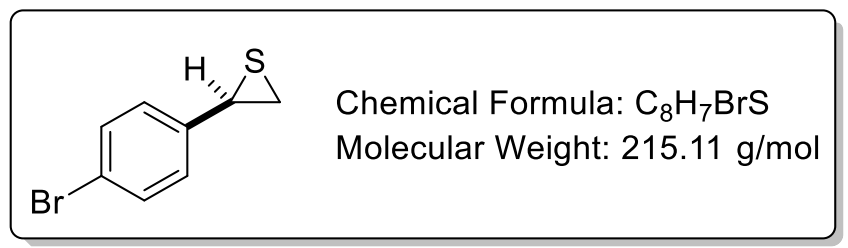

(R)-3e: White solid, $51 \%$ yield; ${ }^{1} \mathbf{H}$ NMR $\left(500 \mathrm{MHz}, \mathrm{CD}_{2} \mathrm{Cl}_{2}\right): \delta 7.34(\mathrm{dt}, J=8.5,2.2 \mathrm{~Hz}, 2 \mathrm{H}), 7.08(\mathrm{dt}, J=8.5$, $2.2 \mathrm{~Hz}, 2 \mathrm{H}), 3.77(\mathrm{t}, J=6.1 \mathrm{~Hz}, 1 \mathrm{H}), 2.79(\mathrm{dd}, J=6.6,1.6 \mathrm{~Hz}, 1 \mathrm{H}), 2.52(\mathrm{dd}, J=5.5,1.6 \mathrm{~Hz}, 1 \mathrm{H}) ;{ }^{13} \mathbf{C ~ N M R}$ $\left(125 \mathrm{MHz}, \mathrm{CD}_{2} \mathrm{Cl}_{2}\right): \delta 139.1,132.0,128.9,121.5,35.6,27.6 ;$ HRMS (m/z) calcd for $\mathrm{C}_{8} \mathrm{H}_{7} \mathrm{BrS}_{\mathrm{C}}$ [M]+: 213.9452, found: $213.9450 .[\alpha]_{\mathrm{D}}^{25}:+18.0^{\circ}\left(\mathrm{c}=1.0, \mathrm{CH}_{2} \mathrm{Cl}_{2}\right)$. The enantiomeric ratio (94.5:5.5 er) was determined by chiral HPLC analysis using an OD-3 column: heptane, $1.0 \mathrm{~mL} / \mathrm{min}, 235 \mathrm{~nm}, \tau 1=5.9 \mathrm{~min}, \tau 2=6.4 \mathrm{~min}$.

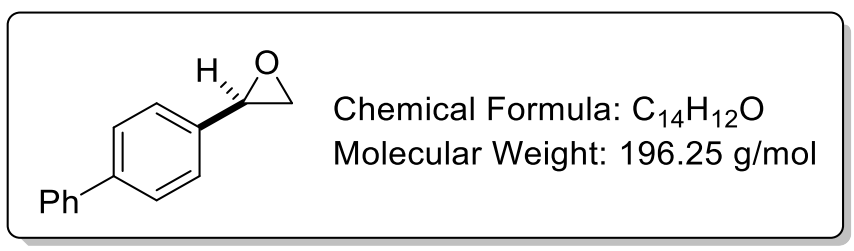

(R)-1f: ${ }^{6}$ White solid, $45 \%$ yield; ${ }^{1} \mathbf{H}$ NMR $\left(500 \mathrm{MHz}, \mathrm{CD}_{2} \mathrm{Cl}_{2}\right): \delta 7.60-7.57(\mathrm{~m}, 4 \mathrm{H}), 7.47-7.34(\mathrm{~m}, 5 \mathrm{H}), 3.92(\mathrm{dd}$, $J=4.0,2.6 \mathrm{~Hz}, 1 \mathrm{H}), 3.19(\mathrm{dd}, J=5.6,4.0 \mathrm{~Hz}, 1 \mathrm{H}), 2.85(\mathrm{dd}, J=5.6,2.6 \mathrm{~Hz}, 1 \mathrm{H}) .[\alpha]_{\mathrm{D}}{ }^{25}:-25.0^{\circ}\left(\mathrm{c}=0.5, \mathrm{CHCl}_{3}\right)$. Lit. $^{6}[\alpha]_{\mathrm{D}}{ }^{24}:+28.3^{\circ}\left(\mathrm{c}=1.05, \mathrm{CHCl}_{3}, \mathrm{~S}\right.$-configuration, $>99 \%$ ee $)$. The enantiomeric ratio $(96: 4$ er $)$ was determined by chiral HPLC analysis using an IC-3 column: heptane $/ i$-PrOH 99:1, $0.50 \mathrm{~mL} / \mathrm{min}, 254 \mathrm{~nm}, \tau 1=$ $11.8 \mathrm{~min}, \tau 2=15.0 \mathrm{~min}$.

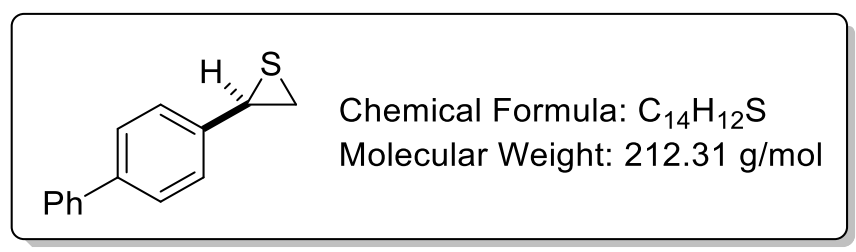

(R)-3f: White solid, 50\% yield; ${ }^{1} \mathbf{H}$ NMR $\left(500 \mathrm{MHz}, \mathrm{CD}_{2} \mathrm{Cl}_{2}\right): \delta$ 7.51-7.45 (m, 4H), 7.37-7.24 (m, $\left.5 \mathrm{H}\right), 3.87$ (t, $J$ $=6.1 \mathrm{~Hz}, 1 \mathrm{H}), 2.82(\mathrm{dd}, J=6.6,1.6 \mathrm{~Hz}, 1 \mathrm{H}), 2.63(\mathrm{dd}, J=5.6,1.6 \mathrm{~Hz}, 1 \mathrm{H}) ;{ }^{13} \mathbf{C ~ N M R}\left(125 \mathrm{MHz}, \mathrm{CD}_{2} \mathrm{Cl}_{2}\right): \delta$ $141.8,140.9,140.8,138.9,129.2,127.8,127.6,127.3,36.2,27.5$. HRMS (m/z) calcd for $\mathrm{C}_{14} \mathrm{H}_{12} \mathrm{~S}[\mathrm{M}]+$ : 212.0660, found: $212.0662 .[\alpha]_{\mathrm{D}}^{25}:-29.0^{\circ}\left(\mathrm{c}=0.3, \mathrm{CHCl}_{3}\right)$. The enantiomeric ratio $(95.5: 4.5 \mathrm{er})$ was determined by chiral HPLC analysis using an OD-3R column: water/MeCN 30:70, $0.5 \mathrm{~mL} / \mathrm{min}, 254 \mathrm{~nm}, \tau 1=15.6 \mathrm{~min}, \tau 2=$ $20.2 \mathrm{~min}$. 


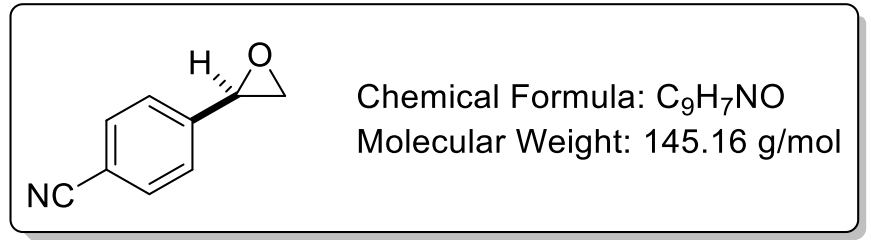

(R)-1g: ${ }^{9}$ White solid, $46 \%$ yield; ${ }^{1} \mathbf{H}$ NMR $\left(500 \mathrm{MHz}, \mathrm{CDCl}_{3}\right): \delta 7.65(\mathrm{dt}, J=8.3,1.6 \mathrm{~Hz}, 2 \mathrm{H}), 7.39(\mathrm{dt}, J=8.3$, $1.6 \mathrm{~Hz}, 2 \mathrm{H}), 3.91(\mathrm{dd}, J=4.0,2.5 \mathrm{~Hz}, 1 \mathrm{H}), 3.21(\mathrm{dd}, J=5.6,4.1 \mathrm{~Hz}, 1 \mathrm{H}), 2.76(\mathrm{dd}, J=5.6,2.5 \mathrm{~Hz}, 1 \mathrm{H}) ;[\alpha]_{\mathrm{D}}{ }^{25}$ : $-33.6^{\circ}\left(\mathrm{c}=0.5, \mathrm{CHCl}_{3}\right)$. The enantiomeric ratio (94:6 er) was determined by chiral HPLC analysis using an IC-3 column: heptane $/ i$-PrOH 95:5, $1.0 \mathrm{~mL} / \mathrm{min}, 205 \mathrm{~nm}, \tau 1=12.5 \mathrm{~min}, \tau 2=13.4 \mathrm{~min}$.

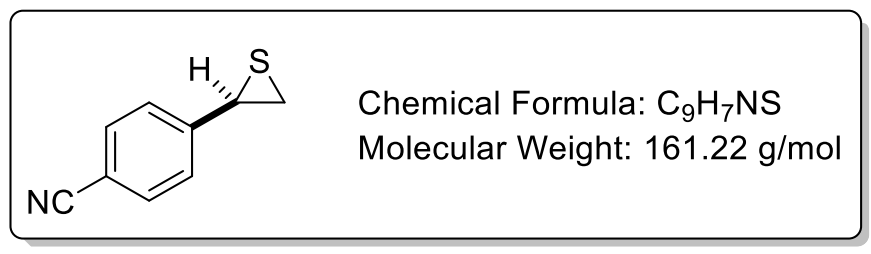

(R)-3g: White solid, 49\% yield; ${ }^{1} \mathbf{H}$ NMR $\left(500 \mathrm{MHz}, \mathrm{CD}_{2} \mathrm{Cl}_{2}\right): \delta 7.51$ (dt, $\left.J=8.4,1.8 \mathrm{~Hz}, 2 \mathrm{H}\right), 7.51(\mathrm{dt}, J=8.4$, $1.8 \mathrm{~Hz}, 2 \mathrm{H}), 3.81(\mathrm{dd}, J=6.4,5.6 \mathrm{~Hz}, 1 \mathrm{H}), 2.85(\mathrm{dd}, J=6.5,1.6 \mathrm{~Hz}, 1 \mathrm{H}), 2.56(\mathrm{dd}, J=5.4,1.7 \mathrm{~Hz}, 1 \mathrm{H}) ;{ }^{13} \mathrm{C}$ NMR $\left(125 \mathrm{MHz}, \mathrm{CD}_{2} \mathrm{Cl}_{2}\right): \delta 145.6,132.7,127.9,119.0,115.6,35.2,28.1 ; \mathbf{H R M S}(\mathrm{m} / \mathrm{z})$ calcd for $\mathrm{C}_{9} \mathrm{H}_{7} \mathrm{NS}[\mathrm{M}]+:$ 161.0299, found: 161.0299. $[\alpha]_{\mathrm{D}}^{25}:+38.6^{\circ}\left(\mathrm{c}=0.3, \mathrm{CH}_{2} \mathrm{Cl}_{2}\right)$. The enantiomeric ratio $(95.5: 4.5$ er $)$ was determined by chiral HPLC analysis using an AD-3 column: heptane $/ i$-PrOH 95:5, $1.0 \mathrm{~mL} / \mathrm{min}, 205 \mathrm{~nm}, \tau 1=6.2$ $\min , \tau 2=6.8 \min$.

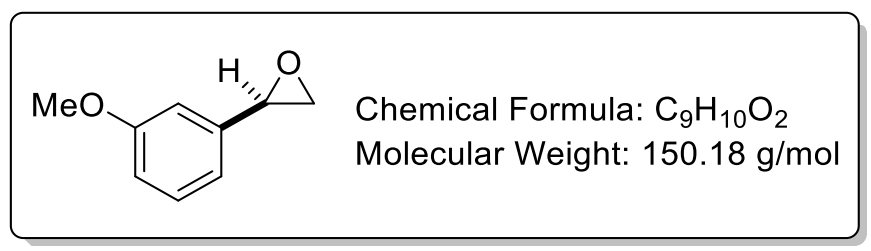

(R)-1h: ${ }^{6}$ Colorless liquid, 45\% yield; ${ }^{1} \mathbf{H}$ NMR (500 MHz, $\left.\mathrm{CDCl}_{3}\right): \delta 7.25(\mathrm{t}, J=7.8,1 \mathrm{H}), 6.90-6.80(\mathrm{~m}, 3 \mathrm{H})$, $3.84(\mathrm{dd}, J=4.0,2.6 \mathrm{~Hz}, 1 \mathrm{H}), 3.80(\mathrm{~s}, 3 \mathrm{H}), 3.12(\mathrm{dd}, J=5.6,4.0 \mathrm{~Hz}, 1 \mathrm{H}), 2.77(\mathrm{dd}, J=5.6,2.6 \mathrm{~Hz}, 1 \mathrm{H}) ;[\alpha]_{\mathrm{D}}^{25}$ : $-15.2^{\circ}\left(\mathrm{c}=0.5, \mathrm{CHCl}_{3}\right)$. Lit. ${ }^{6}[\alpha]_{\mathrm{D}}{ }^{24}:+12.6^{\circ}\left(\mathrm{c}=0.88, \mathrm{CHCl}_{3}, \mathrm{~S}\right.$-configuration, $>99 \%$ ee $)$. The enantiomeric ratio (96.5:3.5 er) was determined by chiral HPLC analysis using an IC-3 column: heptane $/ i$-PrOH 95:5, 1.0 mL/min, $205 \mathrm{~nm}, \tau 1=5.0 \mathrm{~min}, \tau 2=5.9 \mathrm{~min}$.

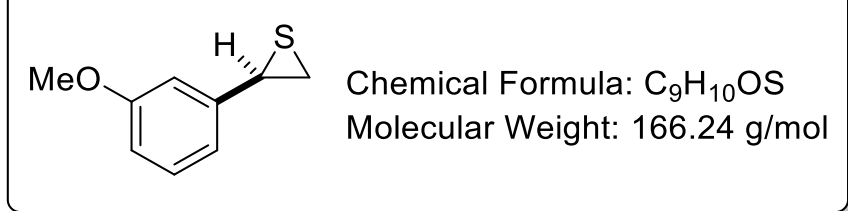


(R)-3h: Colorless liquid, 47\% yield; ${ }^{1} \mathbf{H}$ NMR $\left(500 \mathrm{MHz}, \mathrm{CD}_{2} \mathrm{Cl}_{2}\right): \delta 7.21(\mathrm{t}, J=7.9,1 \mathrm{H}), 6.88(\mathrm{~d}, J=7.7 \mathrm{~Hz}$, $1 \mathrm{H}), 6.82-6.77(\mathrm{~m}, 2 \mathrm{H}), 3.88(\mathrm{t}, J=6.1 \mathrm{~Hz}, 1 \mathrm{H}), 3.78(\mathrm{~s}, 3 \mathrm{H}), 2.85(\mathrm{dd}, J=6.6,1.6 \mathrm{~Hz}, 1 \mathrm{H}), 2.64(\mathrm{dd}, J=5.6$, $1.6 \mathrm{~Hz}, 1 \mathrm{H}) ;{ }^{13} \mathbf{C}$ NMR $\left(125 \mathrm{MHz}, \mathrm{CD}_{2} \mathrm{Cl}_{2}\right): \delta 160.3,141.4,129.9,119.5,113.5,112.5,55.6,36.3,27.5$. HRMS $(\mathrm{m} / \mathrm{z})$ calcd for $\mathrm{C}_{9} \mathrm{H}_{10} \mathrm{OS}[\mathrm{M}]+:$ : 166.0452 , found: $166.0452 .[\alpha]_{\mathrm{D}}^{25}:-36.0^{\circ}\left(\mathrm{c}=0.5, \mathrm{CH}_{2} \mathrm{Cl}_{2}\right)$. The enantiomeric ratio (97.5:2.5 er) was determined by chiral HPLC analysis using an OJ-H column: heptane/i-PrOH 99:1, 0.50 $\mathrm{mL} / \mathrm{min}, 220 \mathrm{~nm}, \tau 1=25.7 \mathrm{~min}, \tau 2=26.6 \mathrm{~min}$.

$$
\begin{aligned}
& \text { Chemical Formula: } \mathrm{C}_{8} \mathrm{H}_{7} \mathrm{FO} \\
& \text { Molecular Weight: } 138.14 \mathrm{~g} / \mathrm{mol}
\end{aligned}
$$

(R)-1i: ${ }^{10}$ Colorless liquid, 43\% yield; ${ }^{1} \mathbf{H}$ NMR $\left(500 \mathrm{MHz}, \mathrm{CD}_{2} \mathrm{Cl}_{2}\right): \delta$ 7.33-7.29 (m, 1H), 7.10-6.96 (m, 3H), $3.86(\mathrm{dd}, J=3.7,2.8 \mathrm{~Hz}, 1 \mathrm{H}), 3.15(\mathrm{dd}, J=4.1,5.6 \mathrm{~Hz}, 1 \mathrm{H}), 2.76(\mathrm{dd}, J=5.6,2.6 \mathrm{~Hz}, 1 \mathrm{H}) ;[\alpha]_{\mathrm{D}}^{25}:-17.8^{\circ}(\mathrm{c}=$ $1.0, \mathrm{CHCl}_{3}$ ). The enantiomeric ratio (94.5:5.5 er) was determined by chiral GC analysis using a Hydrodex $-\beta$ TBDAc column $(0.4 \mathrm{~mm} \times 25 \mathrm{~m}): 110^{\circ} \mathrm{C}$ for $15 \mathrm{~min}, \tau 1=7.7 \mathrm{~min}, \tau 2=8.1 \mathrm{~min}$.

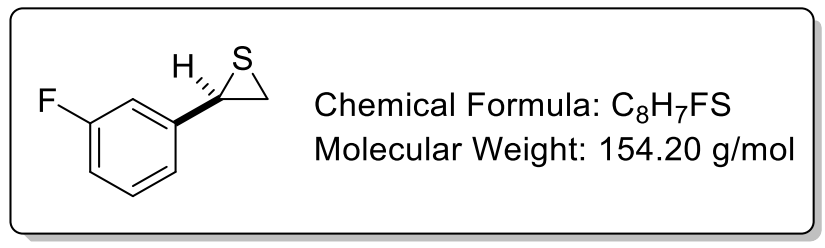

(R)-3i: Colorless liquid, $47 \%$ yield; ${ }^{1} \mathbf{H}$ NMR $\left(500 \mathrm{MHz}, \mathrm{CD}_{2} \mathrm{Cl}_{2}\right): \delta$ 7.30-7.25 (m, $\left.1 \mathrm{H}\right), 7.12(\mathrm{dt}, J=7.8,1.2 \mathrm{~Hz}$, $1 \mathrm{H}), 6.99-6.93(\mathrm{~m}, 2 \mathrm{H}), 3.88(\mathrm{t}, J=6.0 \mathrm{~Hz}, 1 \mathrm{H}), 2.88(\mathrm{dd}, J=6.6,1.6 \mathrm{~Hz}, 1 \mathrm{H}), 2.62(\mathrm{dd}, J=5.6,1.6 \mathrm{~Hz}, 1 \mathrm{H})$; ${ }^{13}$ C NMR $\left(125 \mathrm{MHz}, \mathrm{CD}_{2} \mathrm{Cl}_{2}\right): \delta 163.0\left(\mathrm{~d}, J_{\mathrm{C}-\mathrm{F}}=246.5 \mathrm{~Hz}\right), 142.7\left(\mathrm{~d}, J_{\mathrm{C}-\mathrm{F}}=7.2 \mathrm{~Hz}\right), 130.4\left(\mathrm{~d}, J_{\mathrm{C}-\mathrm{F}}=8.4 \mathrm{~Hz}\right)$, $123.2\left(\mathrm{~d}, J_{\mathrm{C}-\mathrm{F}}=3.0 \mathrm{~Hz}\right), 114.8\left(\mathrm{~d}, J_{\mathrm{C}-\mathrm{F}}=21.4 \mathrm{~Hz}\right), 113.6\left(\mathrm{~d}, J_{\mathrm{C}-\mathrm{F}}=22.3 \mathrm{~Hz}\right), 35.5,27.7 ;{ }^{19} \mathbf{F}$ NMR $(282 \mathrm{MHz}$, $\left.\mathrm{CD}_{2} \mathrm{Cl}_{2}\right): \delta$-114.0. HRMS $(\mathrm{m} / \mathrm{z})$ calcd for $\mathrm{C}_{8} \mathrm{H}_{7} \mathrm{FS}[\mathrm{M}]+:$ 154.0252, found: $154.0251 .[\alpha]_{\mathrm{D}}^{25}:-25.8^{\circ}(\mathrm{c}=1.0$, $\mathrm{CH}_{2} \mathrm{Cl}_{2}$ ). The enantiomeric ratio (95.5:4.5 er) was determined by chiral GC analysis using a Hydrodex- $\beta$-TBDAc column $(0.4 \mathrm{~mm} \times 25 \mathrm{~m}): 110{ }^{\circ} \mathrm{C}$ for $30 \mathrm{~min}, \tau 1=21.7 \mathrm{~min}, \tau 2=23.0 \mathrm{~min}$.

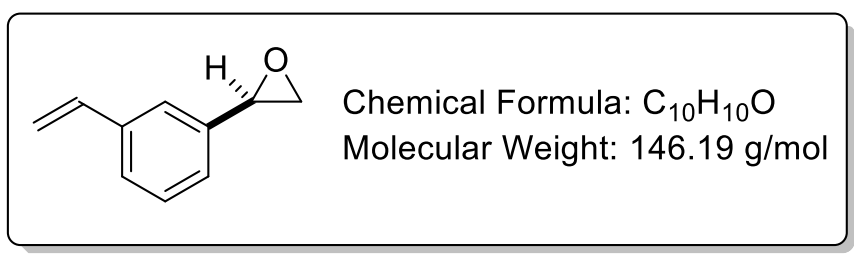

$(\boldsymbol{R})$-1j: ${ }^{11}$ Colorless liquid, 47\% yield; ${ }^{1} \mathbf{H}$ NMR $\left(500 \mathrm{MHz}, \mathrm{CDCl}_{3}\right): \delta$ 7.37-7.30 (m, 3H), $7.17(\mathrm{dt}, J=7.6,1.6$ $\mathrm{Hz}, 1 \mathrm{H}), 6.70(\mathrm{dd}, J=17.7,11.0 \mathrm{~Hz}, 1 \mathrm{H}), 5.76(\mathrm{dd}, J=17.7,0.8 \mathrm{~Hz}, 1 \mathrm{H}), 5.27(\mathrm{dd}, J=11.0,0.8 \mathrm{~Hz}, 1 \mathrm{H}), 3.87$ 
$(\mathrm{dd}, J=4.0,2.6 \mathrm{~Hz}, 1 \mathrm{H}), 3.15(\mathrm{dd}, J=4.1,5.4 \mathrm{~Hz}, 1 \mathrm{H}), 2.66(\mathrm{dd}, J=5.4,2.6 \mathrm{~Hz}, 1 \mathrm{H}) ;{ }^{13} \mathbf{C} \mathbf{N M R}(125 \mathrm{MHz}$, $\left.\mathrm{CDCl}_{3}\right): \delta 132.72,132.68,131.2,123.5,120.9,119.2,118.0,109.2,47.1,46.0 .[\alpha]_{\mathrm{D}}^{25}:-13.6^{\circ}\left(\mathrm{c}=0.5, \mathrm{CHCl}_{3}\right)$. The enantiomeric ratio (96:4 er) was determined by chiral HPLC analysis using an IC-3 column: heptane/i-PrOH 99:1, $0.5 \mathrm{~mL} / \mathrm{min}, 205 \mathrm{~nm}, \tau 1=8.2 \mathrm{~min}, \tau 2=9.0 \mathrm{~min}$.

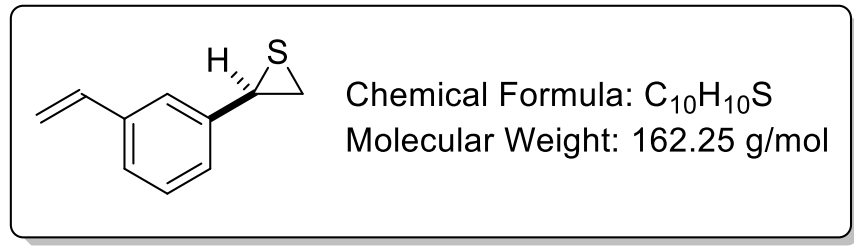

(R)-3j: Colorless liquid, $48 \%$ yield; ${ }^{1} \mathbf{H}$ NMR $\left(500 \mathrm{MHz}, \mathrm{CD}_{2} \mathrm{Cl}_{2}\right): \delta$ 7.33-7.24 (m, 3H), $7.17(\mathrm{dt}, J=7.5,1.6 \mathrm{~Hz}$, 2H), $6.70(\mathrm{dd}, J=17.7,11.0 \mathrm{~Hz}, 1 \mathrm{H}), 5.76(\mathrm{dd}, J=17.7,0.8 \mathrm{~Hz}, 1 \mathrm{H}), 5.26(\mathrm{dd}, J=11.0,0.8 \mathrm{~Hz}, 1 \mathrm{H}), 3.90(\mathrm{t}, J=$ $6.1 \mathrm{~Hz}, 1 \mathrm{H}), 2.88(\mathrm{dd}, J=6.6,1.6 \mathrm{~Hz}, 1 \mathrm{H}), 2.66(\mathrm{dd}, J=5.6,1.6 \mathrm{~Hz}, 1 \mathrm{H}) ;{ }^{13} \mathbf{C} \mathbf{N M R}\left(125 \mathrm{MHz}, \mathrm{CD}_{2} \mathrm{Cl}_{2}\right): \delta$ 140.0, 138.3, 136.8, 129.1, 126.5, 125.8, 125.0, 114.5, 36.2, 27.5; HRMS (m/z) calcd for $\mathrm{C}_{10} \mathrm{H}_{10} \mathrm{~S}[\mathrm{M}]+$ : 162.0503, found: $162.0505 .[\alpha]_{\mathrm{D}}^{25}:-53.2^{\circ}\left(\mathrm{c}=1.0, \mathrm{CH}_{2} \mathrm{Cl}_{3}\right)$. The enantiomeric ratio $(97: 3 \mathrm{er})$ was determined by chiral HPLC analysis using an OJ-H column: heptane/isopropanol 99:1, $0.5 \mathrm{~mL} / \mathrm{min}, 220 \mathrm{~nm},, \tau 1=17.3 \mathrm{~min}, \tau 2$ $=18.0 \mathrm{~min}$.

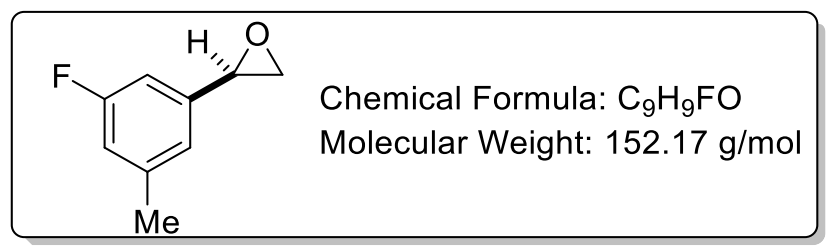

(R)-1k: Colorless liquid, $42 \%$ yield; ${ }^{1} \mathbf{H}$ NMR $\left(500 \mathrm{MHz}, \mathrm{CD}_{2} \mathrm{Cl}_{2}\right): \delta 6.89(\mathrm{~s}, \mathrm{br}, 1 \mathrm{H}), 6.82-6.76(\mathrm{~m}, 2 \mathrm{H}), 3.81$ (dd, $J=3.8,2.6 \mathrm{~Hz}, 1 \mathrm{H}), 3.12(\mathrm{dd}, J=5.4,4.0 \mathrm{~Hz}, 1 \mathrm{H}), 2.75(\mathrm{dd}, J=5.6,2.6 \mathrm{~Hz}, 1 \mathrm{H}), 2.34(\mathrm{~s}, 3 \mathrm{H}) ;{ }^{13} \mathbf{C ~ N M R}$ $\left(125 \mathrm{MHz}, \mathrm{CD}_{2} \mathrm{Cl}_{2}\right): \delta 163.0\left(\mathrm{~d}, J_{\mathrm{C}-\mathrm{F}}=254.0 \mathrm{~Hz}\right), 140.7\left(\mathrm{~d}, J_{\mathrm{C}-\mathrm{F}}=7.8 \mathrm{~Hz}\right), 140.0\left(\mathrm{~d}, J_{\mathrm{C}-\mathrm{F}}=8.0 \mathrm{~Hz}\right), 121.9\left(\mathrm{~d}, J_{\mathrm{C}-\mathrm{F}}\right.$ $=2.0 \mathrm{~Hz}), 115.8\left(\mathrm{~d}, J_{\mathrm{C}-\mathrm{F}}=20.7 \mathrm{~Hz}\right), 109.4\left(\mathrm{~d}, J_{\mathrm{C}-\mathrm{F}}=22.9 \mathrm{~Hz}\right), 51.8\left(\mathrm{~d}, J_{\mathrm{C}-\mathrm{F}}=2.1 \mathrm{~Hz}\right), 51.2,21.3\left(\mathrm{~d}, J_{\mathrm{C}-\mathrm{F}}=1.9\right.$ $\mathrm{Hz}$ ); HRMS (m/z) calcd for $\mathrm{C}_{9} \mathrm{H}_{9} \mathrm{FO}[\mathrm{M}]+:$ 152.0637, found: $152.0637 .[\alpha]_{\mathrm{D}}{ }^{25}:-17.0^{\circ}\left(\mathrm{c}=1.0, \mathrm{CHCl}_{3}\right)$. The enantiomeric ratio (94.5:5.5 er) was determined by chiral HPLC analysis using an IC-3 column: heptane/ $i$-PrOH $99: 1,0.5 \mathrm{~mL} / \mathrm{min}, 205 \mathrm{~nm}, \tau 1=7.5 \mathrm{~min}, \tau 2=7.9 \mathrm{~min}$.

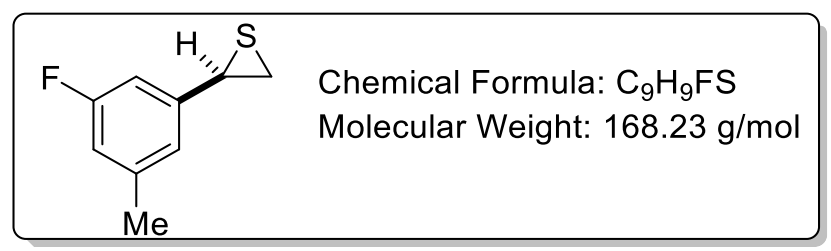


(R)-3k: Colorless liquid, 48\% yield; ${ }^{1} \mathbf{H}$ NMR $\left(500 \mathrm{MHz}, \mathrm{CD}_{2} \mathrm{Cl}_{2}\right): \delta 6.93(\mathrm{t}, J=0.6 \mathrm{~Hz}, 1 \mathrm{H}), 6.78(\mathrm{dt}, J=9.6$, $0.6 \mathrm{~Hz}, 2 \mathrm{H}), 3.84(\mathrm{t}, J=6.0 \mathrm{~Hz}, 1 \mathrm{H}), 2.85(\mathrm{dd}, J=6.6,1.6 \mathrm{~Hz}, 1 \mathrm{H}), 2.61(\mathrm{dd}, J=5.6,1.6 \mathrm{~Hz}, 1 \mathrm{H}), 2.32(\mathrm{~s}, 3 \mathrm{H})$; ${ }^{13}$ C NMR $\left(125 \mathrm{MHz}, \mathrm{CD}_{2} \mathrm{Cl}_{2}\right): \delta 163.0\left(\mathrm{~d}, J_{\mathrm{C}-\mathrm{F}}=244.0 \mathrm{~Hz}\right), 142.2\left(\mathrm{~d}, J_{\mathrm{C}-\mathrm{F}}=8.4 \mathrm{~Hz}\right), 141.2\left(\mathrm{~d}, J_{\mathrm{C}-\mathrm{F}}=8.2 \mathrm{~Hz}\right)$, $123.8\left(\mathrm{~d}, J_{\mathrm{C}-\mathrm{F}}=2.1 \mathrm{~Hz}\right), 115.5\left(\mathrm{~d}, J_{\mathrm{C}-\mathrm{F}}=21.1 \mathrm{~Hz}\right), 110.6\left(\mathrm{~d}, J_{\mathrm{C}-\mathrm{F}}=23.2 \mathrm{~Hz}\right), 35.6\left(\mathrm{~d}, J_{\mathrm{C}-\mathrm{F}}=2.7 \mathrm{~Hz}\right), 27.6,21.4$; ${ }^{19}$ F NMR (282 MHz, $\left.\mathrm{CD}_{2} \mathrm{Cl}_{2}\right): \delta$-115.2. HRMS (m/z) calcd for $\mathrm{C}_{9} \mathrm{H}_{9} \mathrm{FS}[\mathrm{M}]+:$ 168.0409, found: 168.0408. $[\alpha]_{\mathrm{D}}^{25}:-35.6^{\circ}\left(\mathrm{c}=0.5, \mathrm{CH}_{2} \mathrm{Cl}_{2}\right)$. The enantiomeric ratio $(96.5: 3.5 \mathrm{er})$ was determined by chiral HPLC analysis using an OJ-H column: heptane/ $i-\mathrm{PrOH} 99: 1,0.5 \mathrm{~mL} / \mathrm{min}, 220 \mathrm{~nm}, \tau 1=11.0 \mathrm{~min}, \tau 2=11.7 \mathrm{~min}$.

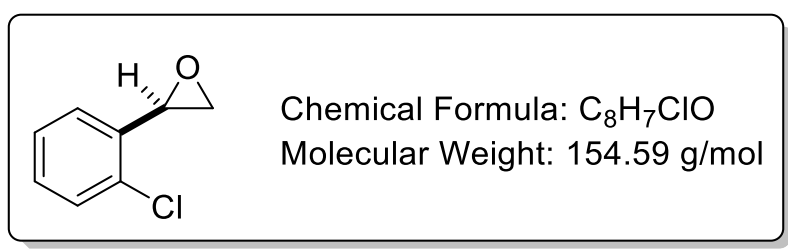

(R)-11: ${ }^{12}$ Colorless liquid, 48\% yield; reaction was warmed up to rt for 24 h. ${ }^{1} \mathbf{H}$ NMR (500 MHz, $\left.\mathrm{CDCl}_{3}\right): \delta$ 7.36-7.34 (m, 1H), 7.26-7.21 (m, 3H), $4.21(\mathrm{dd}, J=4.1,2.6 \mathrm{~Hz}, 1 \mathrm{H}), 3.19(\mathrm{dd}, J=5.7,4.1 \mathrm{~Hz}, 1 \mathrm{H}), 2.66(\mathrm{dd}, J=$ 5.7, $2.6 \mathrm{~Hz}, 1 \mathrm{H}) ;{ }^{13} \mathrm{C}$ NMR $\left(125 \mathrm{MHz}, \mathrm{CDCl}_{3}\right): \delta 135.6,133.3,129.1,128.9,127.0,125.7,50.7,50.0 .[\alpha]_{\mathrm{D}}{ }^{25}:-$ $63.4^{\circ}\left(\mathrm{c}=1.0, \mathrm{CHCl}_{3}\right)$. Lit. ${ }^{12}[\alpha]_{\mathrm{D}}{ }^{20}:-49.7^{\circ}\left(\mathrm{c}=0.7, \mathrm{CHCl}_{3}, \mathrm{R}\right.$-configuration, $81 \%$ ee $)$. The enantiomeric ratio (92:8 er) was determined by chiral HPLC analysis using an IC-3 column: heptane/ $i$-PrOH 99:1, 0.5 mL/min, 205 $\mathrm{nm}, \tau 1=6.0 \mathrm{~min}, \tau 2=7.5 \mathrm{~min}$.

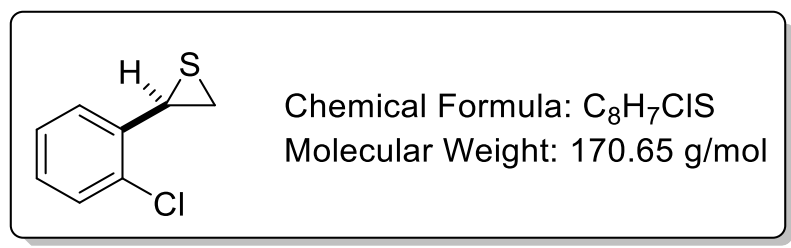

(R)-31: Colorless liquid, 47\% yield; ${ }^{1} \mathbf{H}$ NMR (500 MHz, $\left.\mathrm{CD}_{2} \mathrm{Cl}_{2}\right): \delta$ 7.31-7.30 (m, 1H), 7.15-7.11 (m, $\left.3 \mathrm{H}\right), 4.15$ $(\mathrm{dd}, J=6.4,5.7 \mathrm{~Hz}, 1 \mathrm{H}), 2.82(\mathrm{dd}, J=6.5,1.5 \mathrm{~Hz}, 1 \mathrm{H}), 2.56(\mathrm{dd}, J=5.7,1.5 \mathrm{~Hz}, 1 \mathrm{H}) ;{ }^{13} \mathbf{C} \mathbf{~ N M R}(125 \mathrm{MHz}$, $\left.\mathrm{CD}_{2} \mathrm{Cl}_{2}\right): \delta 137.2,135.5,129.6,129.0,127.7,127.5,33.7,26.5 ; \mathbf{H R M S}(\mathrm{m} / \mathrm{z})$ calcd for $\mathrm{C}_{8} \mathrm{H}_{7} \mathrm{ClS}[\mathrm{M}]+:$ 169.9957, found: $169.9955 .[\alpha]_{\mathrm{D}}{ }^{25}:+150.0^{\circ}\left(\mathrm{c}=1.0, \mathrm{CH}_{2} \mathrm{Cl}_{2}\right)$. The enantiomeric ratio (96.5: 3.5 er) was determined by chiral HPLC analysis using an OJ-H column: heptane/i-PrOH 99:1, $0.2 \mathrm{~mL} / \mathrm{min}, 220 \mathrm{~nm}, \tau 1=31.6 \mathrm{~min}, \tau 2=$ $33.6 \mathrm{~min}$.

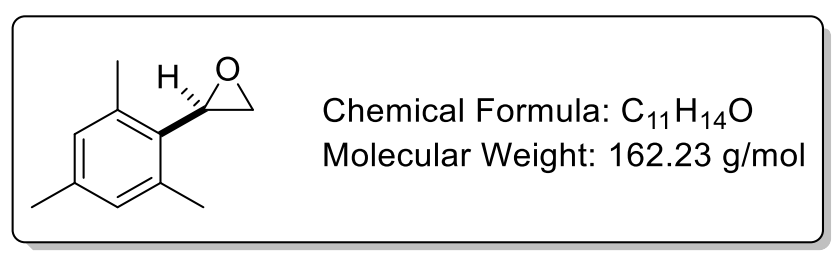


(R)-1m: ${ }^{13}$ White solids, 37\% yield; reaction was warmed up to rt for 24 h. ${ }^{1} \mathbf{H}$ NMR $\left(500 \mathrm{MHz}, \mathrm{CDCl}_{3}\right): \delta 6.81$ $(\mathrm{s}, 2 \mathrm{H}), 4.21(\mathrm{t}, J=3.3 \mathrm{~Hz}, 1 \mathrm{H}), 3.19(\mathrm{dd}, J=5.7,4.1 \mathrm{~Hz}, 1 \mathrm{H}), 2.66(\mathrm{dd}, J=5.7,3.11 \mathrm{H}), 2.36(\mathrm{~s}, 6 \mathrm{H}), 2.26(\mathrm{~s}$, $3 \mathrm{H}) ;{ }^{13} \mathrm{C}$ NMR $\left(125 \mathrm{MHz}, \mathrm{CDCl}_{3}\right): \delta 137.4,137.2,131.0,128.7,50.9,48.7,20.9,19.6 .[\alpha]_{\mathrm{D}}{ }^{25}:-68.3^{\circ}(\mathrm{c}=1.0$, $\mathrm{CHCl}_{3}$ ). The enantiomeric ratio (92.5: $7.5 \mathrm{er}$ ) was determined by chiral HPLC analysis using an IC-3 column: heptane/i-PrOH 99:1, $0.5 \mathrm{~mL} / \mathrm{min}, 205 \mathrm{~nm}, \tau 1=7.2 \mathrm{~min}, \tau 2=8.2 \mathrm{~min}$.

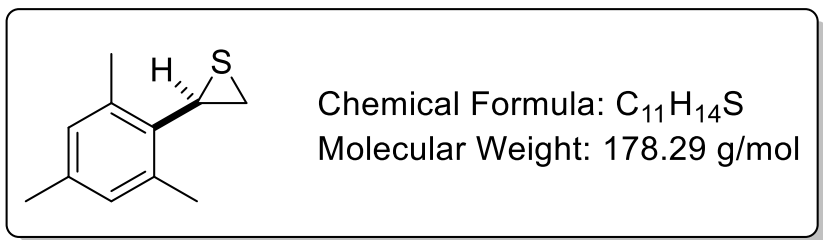

(R)-3m: White solid, 48\% yield; ${ }^{1} \mathbf{H}$ NMR (500 MHz, $\left.\mathrm{CDCl}_{3}\right): \delta 6.84$ (s, 2H), 3.81 (t, J=6.2 Hz, 1H), 2.95 (dd, $J=6.2,1.5 \mathrm{~Hz}, 1 \mathrm{H}), 2.74(\mathrm{dd}, J=6.2,1.4 \mathrm{~Hz}, 1 \mathrm{H}), 2.42(\mathrm{~s}, 6 \mathrm{H}), 2.25(\mathrm{~s}, 3 \mathrm{H}) ;{ }^{13} \mathbf{C ~ N M R}\left(125 \mathrm{MHz}, \mathrm{CD}_{2} \mathrm{Cl}_{2}\right): \delta$ 137.7, 137.1, 132.4, 129.2, 33.1, 27.3, 21.0, 20.8; HRMS (m/z) calcd for $\mathrm{C}_{11} \mathrm{H}_{14} \mathrm{~S}[\mathrm{M}]+$ : 178.0816, found: 178.0815. $[\alpha]_{\mathrm{D}}^{25}:+168.0^{\circ}\left(\mathrm{c}=0.5, \mathrm{CH}_{2} \mathrm{Cl}_{2}\right)$. The enantiomeric ratio $(96: 4$ er $)$ was determined by chiral HPLC analysis using an Amycoat RP column: water:MeCN 60:40, $0.5 \mathrm{~mL} / \mathrm{min}, 205 \mathrm{~nm}, \tau 1=25.4 \mathrm{~min}, \tau 2=27.1 \mathrm{~min}$.

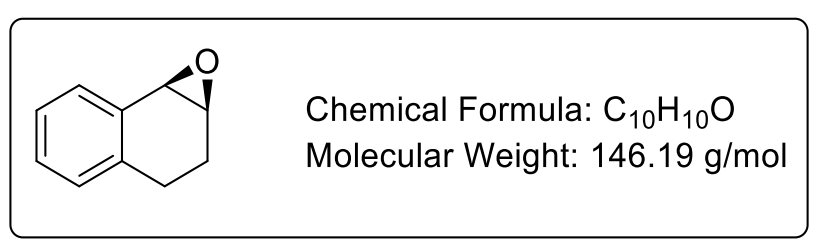

(1R, 2S)-1n: ${ }^{6}$ Colorless liquid, 39\% yield; ${ }^{1} \mathbf{H}$ NMR $\left(500 \mathrm{MHz}, \mathrm{CDCl}_{3}\right): \delta 7.40(\mathrm{dd}, J=7.3,1.3 \mathrm{~Hz}, 1 \mathrm{H}), 7.27-$ $7.18(\mathrm{~m}, 2 \mathrm{H}), 7.08(\mathrm{~d}, J=7.2 \mathrm{~Hz}, 1 \mathrm{H}), 3.85(\mathrm{~d}, J=4.2 \mathrm{~Hz}, 1 \mathrm{H}), 3.73(\mathrm{t}, J=3.5 \mathrm{~Hz}, 1 \mathrm{H}), 2.82-2.75(\mathrm{~m}, 1 \mathrm{H}), 2.54$ $(\mathrm{dd}, J=7.8,5.6 \mathrm{~Hz}, 1 \mathrm{H}), 2.44-2.39(\mathrm{~m}, 1 \mathrm{H}), 1.80-1.73(\mathrm{~m}, 1 \mathrm{H}) .[\alpha]_{\mathrm{D}}{ }^{25}:+123.6^{\circ}\left(\mathrm{c}=1.0, \mathrm{CHCl}_{3}\right) . \mathrm{Lit}^{6}[\alpha]_{\mathrm{D}}{ }^{20}$ : $+133.2^{\circ}\left(\mathrm{c}=1.57, \mathrm{CHCl}_{3}, 1 \mathrm{R}, 2 \mathrm{~S}\right.$-configuration, $\left.84 \% \mathrm{ee}\right)$. The enantiomeric ratio $(92: 8 \mathrm{er})$ was determined by chiral HPLC analysis using an AD-3 column: heptane/i-PrOH 95:5, $1.0 \mathrm{~mL} / \mathrm{min}, 205 \mathrm{~nm}, \tau 1=3.1 \mathrm{~min}, \tau 2=3.6$ $\min$.

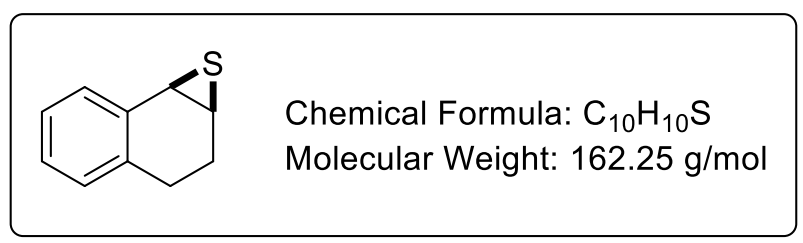

(1R, 2S)-3n: White solid, 47\% yield, solvent was removed under reduced pressure in ice/water bath; ${ }^{1} \mathbf{H}$ NMR $\left(500 \mathrm{MHz}, \mathrm{CDCl}_{3}\right): \delta$ 7.51-7.45 (m, 1H), 7.19-7.15 (m, 2H), 7.06-7.02 (m, 1H), $3.97(\mathrm{~d}, J=6.4 \mathrm{~Hz}, 1 \mathrm{H}), 3.69(\mathrm{~m}$, $1 \mathrm{H}), 2.87-2.80(\mathrm{~m}, 1 \mathrm{H}), 2.52-2.44(\mathrm{~m}, 2 \mathrm{H}), 2.14-2.07(\mathrm{~m}, 1 \mathrm{H}) ;{ }^{13} \mathbf{C} \mathbf{N M R}\left(125 \mathrm{MHz}, \mathrm{CDCl}_{3}\right): \delta 135.6,133.9$, 129.5, 128.6, 127.3, 126.4, 38.0, 37.5, 24.3, 23.5. HRMS (m/z) calcd for $\mathrm{C}_{10} \mathrm{H}_{10} \mathrm{~S}[\mathrm{M}]+$ : 162.0503, found: 
162.0503. $[\alpha]_{\mathrm{D}}^{25}:+38.0^{\circ}\left(\mathrm{c}=1.0, \mathrm{CH}_{2} \mathrm{Cl}_{2}\right)$. The enantiomeric ratio (90.5:9.5 er) was determined by chiral GC analysis using a Hydrodex- $\beta$-TBDAc column $(0.4 \mathrm{~mm}$ x $25 \mathrm{~m}): 150{ }^{\circ} \mathrm{C}$ for $20 \mathrm{~min}, \tau 1=11.4 \mathrm{~min}, \tau 2=12.0 \mathrm{~min}$.

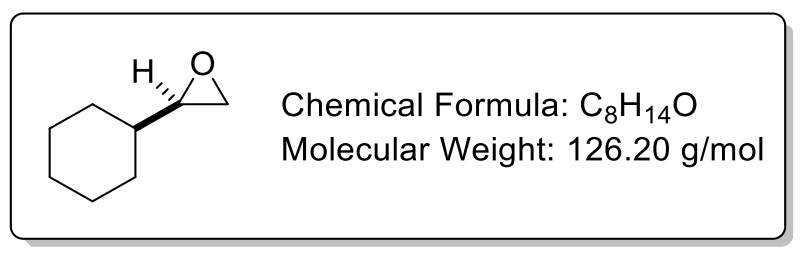

(R)-10: ${ }^{11}$ Colorless liquid, $43 \%$ yield; reaction was warmed up to rt for $24 \mathrm{~h} .{ }^{1} \mathbf{H}$ NMR $\left(500 \mathrm{MHz}, \mathrm{CD}_{2} \mathrm{Cl}_{2}\right): \delta$ 2.59-2.56 (m, 2H), 2.40-2.38 (m, 1H), 1.75-1.53 (m, 5H), 1.18-0.98 (m, 6H) ppm; ${ }^{13} \mathbf{C}$ NMR $\left(125 \mathrm{MHz}, \mathrm{CD}_{2} \mathrm{Cl}_{2}\right)$ : $\delta$ 56.7, 46.0, 40.8, 30.1, 29.2, 26.7, 26.1, $26.0 \mathrm{ppm} ;[\alpha]_{\mathrm{D}}^{25}:-1.2^{\circ}\left(\mathrm{c}=0.5, \mathrm{CHCl}_{3}\right) ; \mathrm{Lit}^{11}[\alpha]_{\mathrm{D}}{ }^{20}:+1.5^{\circ}(\mathrm{c}=1.0$, $\mathrm{CHCl}_{3,81 \%}$ ee). The enantiomeric ratio (77:23 er) was determined by chiral GC analysis using an IVADEX1/PS086 column: $70{ }^{\circ} \mathrm{C}, 30 \mathrm{~min}, \tau 1=10.1 \mathrm{~min}, \tau 2=10.8 \mathrm{~min}$.

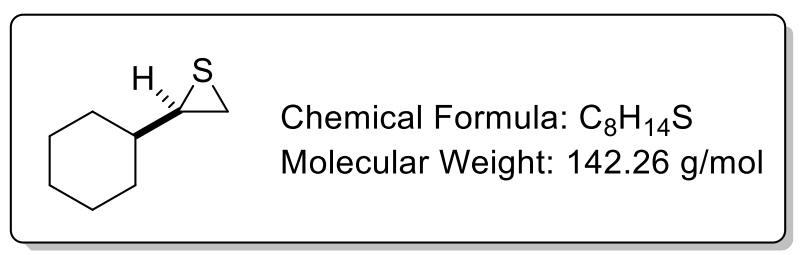

(R)-3o: ${ }^{14}$ Colorless liquid, $49 \%$ yield; ${ }^{1} \mathbf{H}$ NMR $\left(500 \mathrm{MHz}, \mathrm{CD}_{2} \mathrm{Cl}_{2}\right): \delta 2.71-2.66(\mathrm{~m}, 1 \mathrm{H}), 2.44(\mathrm{dd}, J=6.4,1.0$ $\mathrm{Hz}, 1 \mathrm{H}), 2.16(\mathrm{dd}, J=5.8,1.0 \mathrm{~Hz}, 1 \mathrm{H}), 1.84-1.63(\mathrm{~m}, 5 \mathrm{H}), 1.23-1.18(\mathrm{~m}, 5 \mathrm{H}), 0.92-0.87(\mathrm{~m}, 1 \mathrm{H}) ;{ }^{13} \mathbf{C} \mathbf{~ N M R}$ $\left(125 \mathrm{MHz}, \mathrm{CD}_{2} \mathrm{Cl}_{2}\right): \delta 46.8,43.6,34.8,34.6,28.3,27.9,27.8,26.3$; HRMS (m/z) calcd for $\mathrm{C}_{8} \mathrm{H}_{14} \mathrm{~S}[\mathrm{M}+]$ : 142.0816, found: $142.0817 ;[\alpha]_{\mathrm{D}}^{25}:+43.5^{\circ}\left(\mathrm{c}=0.5, \mathrm{CHCl}_{3}\right)$. The enantiomeric ratio $(74: 26 \mathrm{er})$ was determined by chiral GC analysis using an IVADEX-1/PS086 column: $100{ }^{\circ} \mathrm{C}, 15 \mathrm{~min}, \tau 1=7.5 \mathrm{~min}, \tau 2=8.0 \mathrm{~min}$.

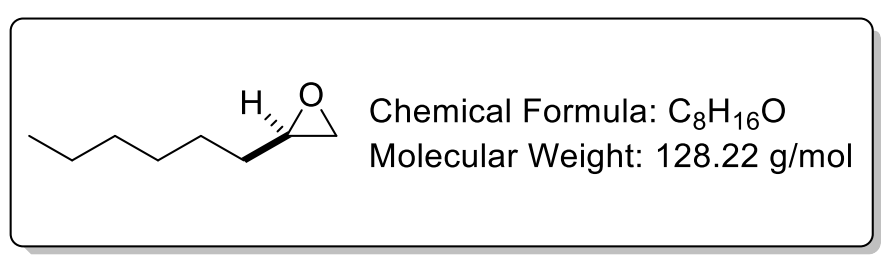

(R)-1p: ${ }^{15}$ Colorless liquid, $44 \%$ yield; reaction was warmed up to rt for $24 \mathrm{~h} .{ }^{1} \mathbf{H}$ NMR $\left(500 \mathrm{MHz}, \mathrm{CDCl}_{3}\right): \delta$ 2.92-2.89 (m, 1H), $2.75(\mathrm{dd}, J=5.0,4.4 \mathrm{~Hz}, 1 \mathrm{H}), 2.15(\mathrm{dd}, J=5.0,2.8 \mathrm{~Hz}, 1 \mathrm{H}), 1.55-1.24(\mathrm{~m}, 10 \mathrm{H}), 0.89$ (t, $J=$ $6.8,3 \mathrm{H}) ;[\alpha]_{\mathrm{D}}{ }^{25}:+6.9^{\circ}\left(\mathrm{c}=0.5, \mathrm{CHCl}_{3}\right)$. Lit. $^{15}[\alpha]_{\mathrm{D}}{ }^{20}:+7.36^{\circ}\left(\mathrm{c}=1.15, \mathrm{CHCl}_{3}, \mathrm{R}\right.$-configuration, $>99 \%$ ee $)$. The enantiomeric ratio (84:16 er) was determined by chiral GC analysis using a LIPODEX G column $(0.4 \mathrm{~mm} \times 25$ m): $50{ }^{\circ} \mathrm{C}, 0.5^{\circ} \mathrm{C} / \mathrm{min}$, till $170{ }^{\circ} \mathrm{C}, \tau 1=15.9 \mathrm{~min}, \tau 2=16.3 \mathrm{~min}$. 


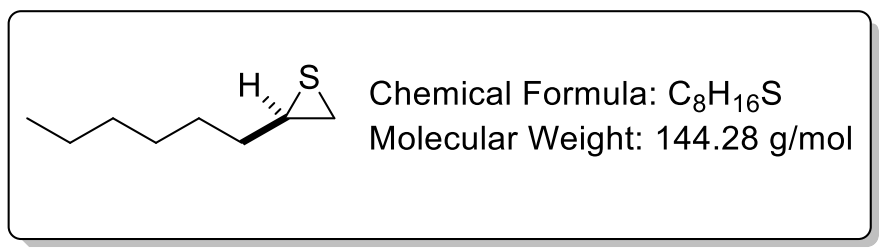

$(\boldsymbol{R})$-3p: $:{ }^{14}$ Colorless liquid, $47 \%$ yield; ${ }^{1} \mathbf{H}$ NMR (500 MHz, $\left.\mathrm{CDCl}_{3}\right): \delta 2.90-2.85(\mathrm{~m}, 1 \mathrm{H}), 2.50(\mathrm{~d}, J=6.2,1 \mathrm{H})$, $2.15(\mathrm{~d}, J=6.1,1 \mathrm{H}), 1.84-1.78(\mathrm{~m}, 1 \mathrm{H}), 1.52-1.42(\mathrm{~m}, 3 \mathrm{H}), 1.38-1.25(\mathrm{~m}, 6 \mathrm{H}), 0.89(\mathrm{t}, J=7.2,3 \mathrm{H}) ;{ }^{13} \mathbf{C} \mathbf{N M R}$ $\left(125 \mathrm{MHz}, \mathrm{CDCl}_{3}\right): \delta 36.6,36.0,31.7,29.3,28.9,25.8,22.5,14.0 ;$ HRMS $(\mathrm{m} / \mathrm{z})$ calcd for $\mathrm{C}_{8} \mathrm{H}_{16} \mathrm{~S}[\mathrm{M}]+$ : 144.0973, found: $144.0972 .[\alpha]_{\mathrm{D}}{ }^{25}:+51.6^{\circ}\left(\mathrm{c}=0.5, \mathrm{CHCl}_{3}\right)$. The enantiomeric ratio $(88: 12 \mathrm{er})$ was determined by chiral GC analysis using a Hydrodex BTBDAc column: $60^{\circ} \mathrm{C}, 1^{\circ} \mathrm{C} / \mathrm{min}$, to $115^{\circ} \mathrm{C}$, then $8{ }^{\circ} \mathrm{C} / \mathrm{min}$ till $220^{\circ} \mathrm{C}$, $\tau 1=44.5 \mathrm{~min}, \tau 2=45.3 \mathrm{~min}$. 


\section{References}

(1) Monaco, M. R.; Poladura, B.; Diaz de los Bernardos Sanchez, M.; Leutzsch, M.; Goddard, R.; List, B. Angew. Chem. Int. Ed. 2014, 53, 7063.

(2) Fulmer, G. R.; Miller, A. J. M.; Sherden, N. H.; Gottlieb, H. E.; Nudelman, A.; Stoltz, B. M.; Bercaw, J. E.; Goldberg, K. I. Organometallics 2010, 29, 2176.

(3) Harris, R. K.; Becker, E. D.; Cabral de Menezes, S. M.; Granger, P.; Hoffman, R. E.; Zilm, K. W.; Pure Appl. Chem. 2008, 80, 59.

(4) Findeisen, M.; Berger, S.; in 50 and More Essential NMR Experiments: A Detailed Guide, Wiley-VCH, 2013.

(5) Soledade, M.; Pedras, C.; Mukund, J. J. Org. Chem. 2005, 70, 1828.

(6) Matsumoto, K.; Kubo, T.; Katsuki, T. Chem. Eur. J. 2009, 15, 6573.

(7) Malaschichin, S.; Fu, C.; Linden, A.; Heimgartner, H. Helv. Chim. Acta 2005, 88, 3253.

(8) Limnios, D.; Kokotos, C. G. J. Org. Chem. 2014, 79, 4270.

(9) Pedragosa-Moreau, S.; Morisseau, C.; Zylber, J.; Archelas, A.; Baratti, J.; Furstoss, R. J. Org. Chem 1996, 61, 7402.

(10) Hickey, M.; Goeddel, D.; Crane, Z.; Shi, Y. PNAS 2004, 101, 5794.

(11) Piccinini, A.; Kavanagh, S. A.; Connon, S. J. Chem. Commun. 2012, 48, 7814.

(12) Tian, H.; She, X.; Yu, H.; Shu, L.; Shi, Y. J. Org. Chem. 2002, 15, 6573.

(13) Wang, Z.-X.; Miller, S. M.; Anderson, O. P.; Shi, Y. J. Org. Chem. 1999, 64, 6443.

(14) Meyers, A. I.; Ford, M. E. J. Org. Chem. 1976, 41, 1735.

(15) Berkessel, A.; Ertürk, E. Adv. Syn. Catal. 2006, 348, 2619. 
7. NMR spectra and HPLC, GC traces.
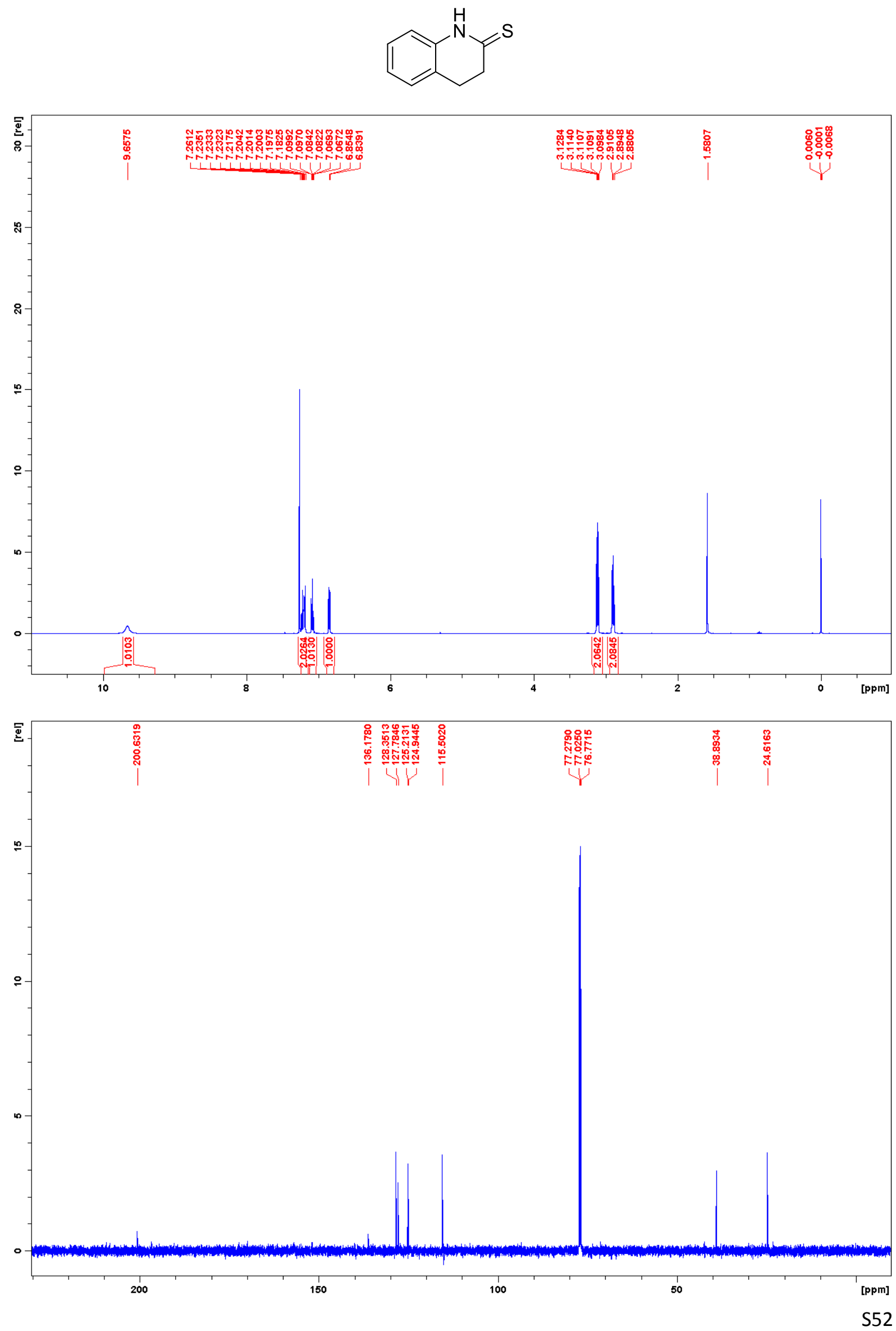

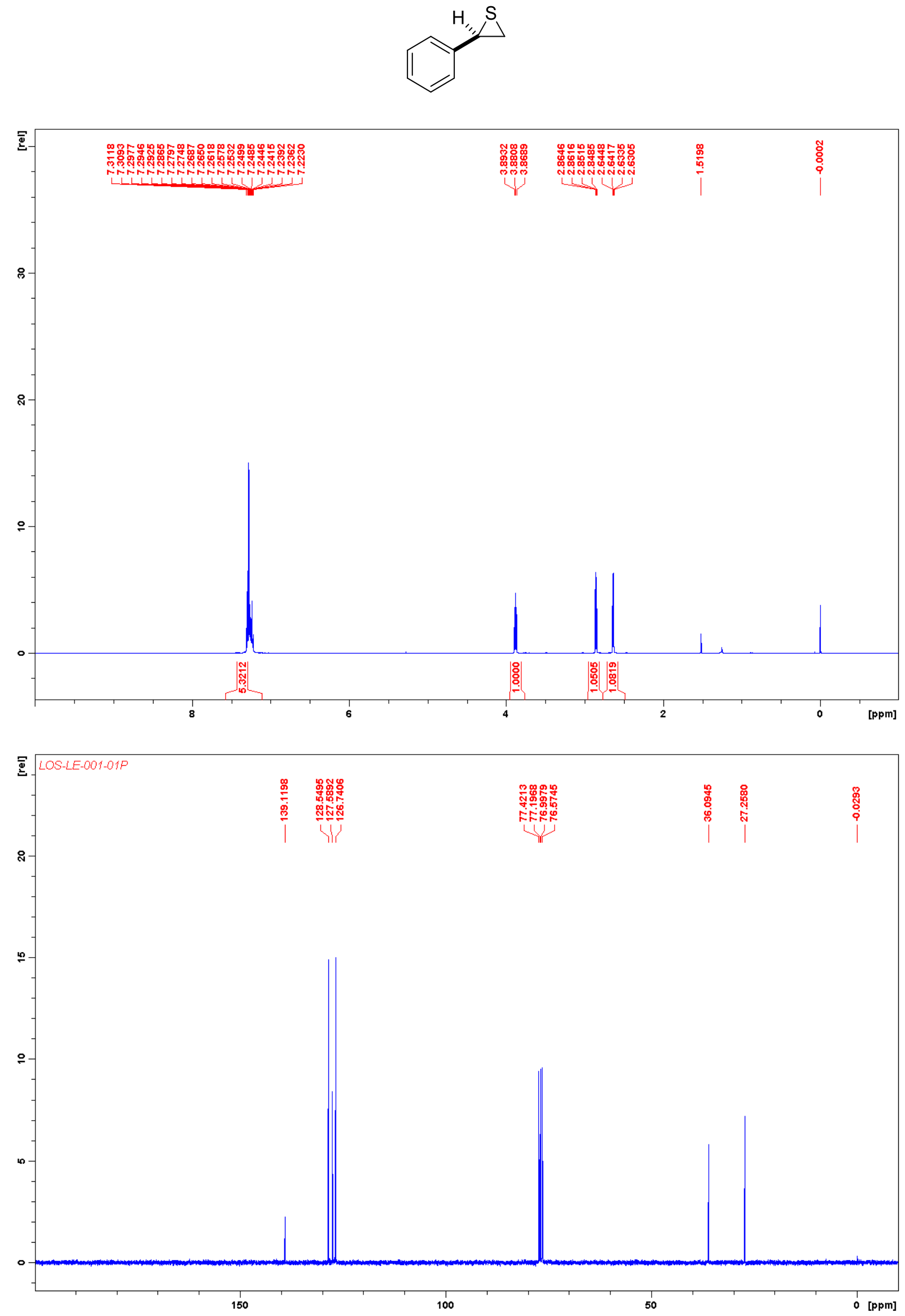

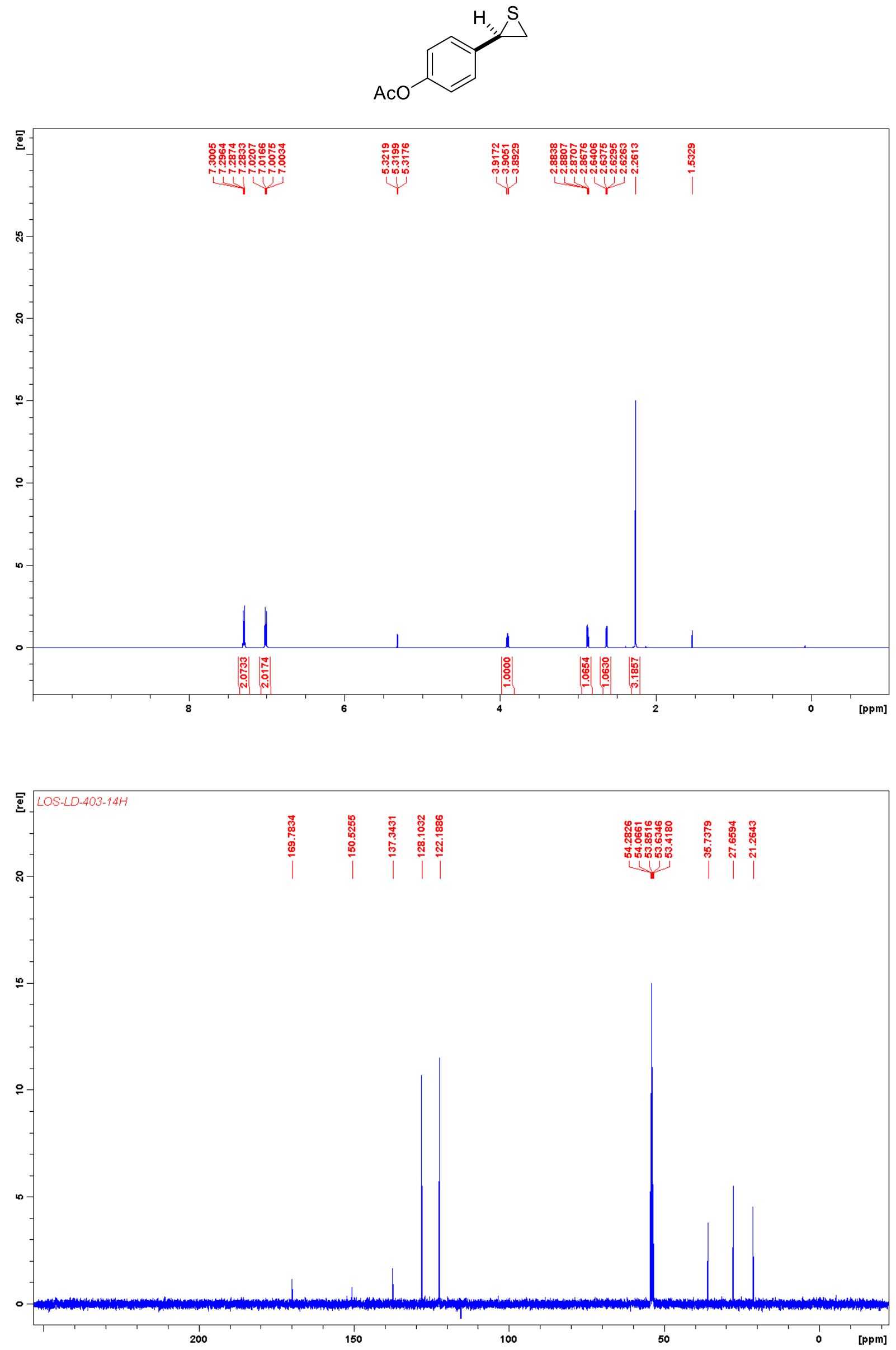

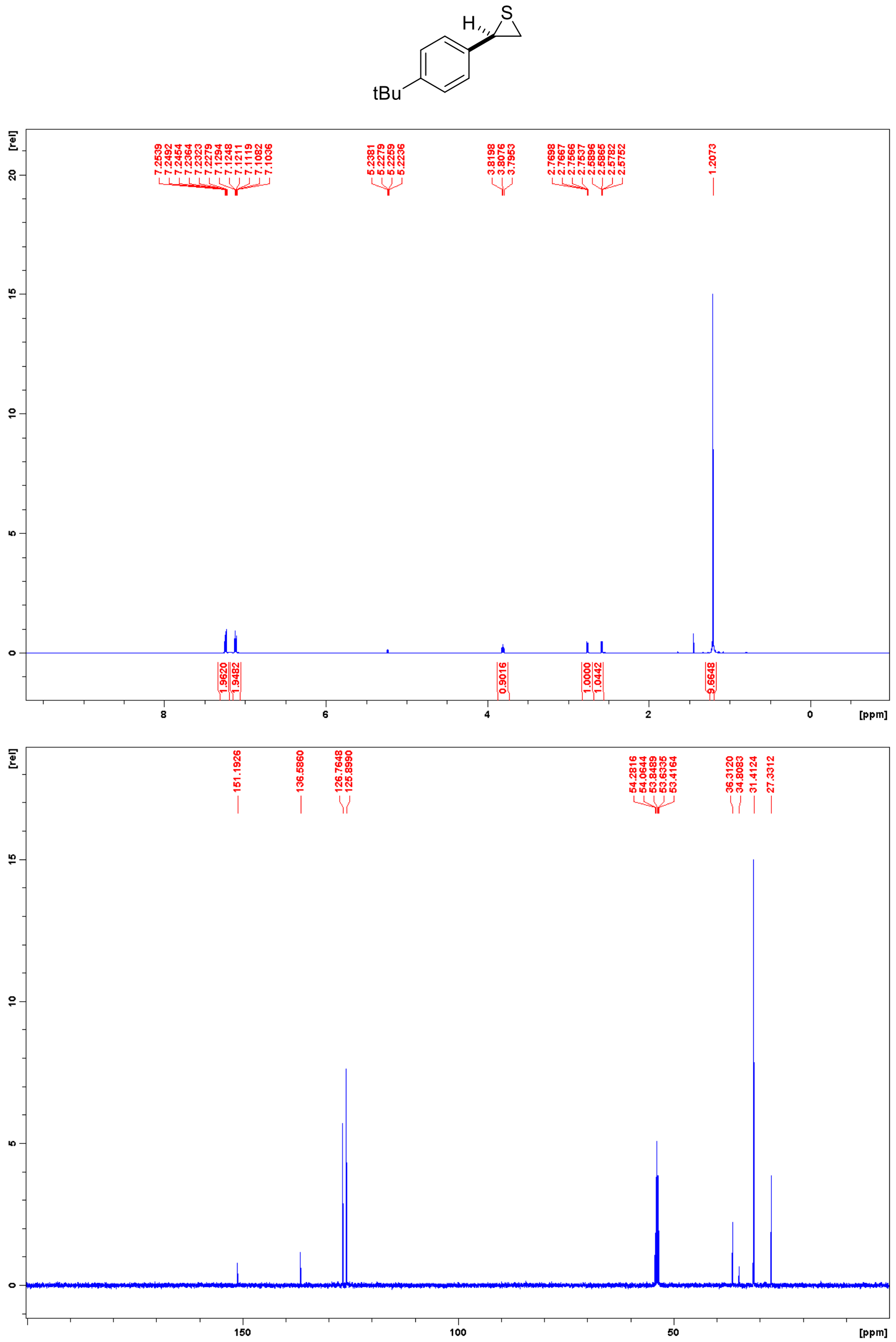

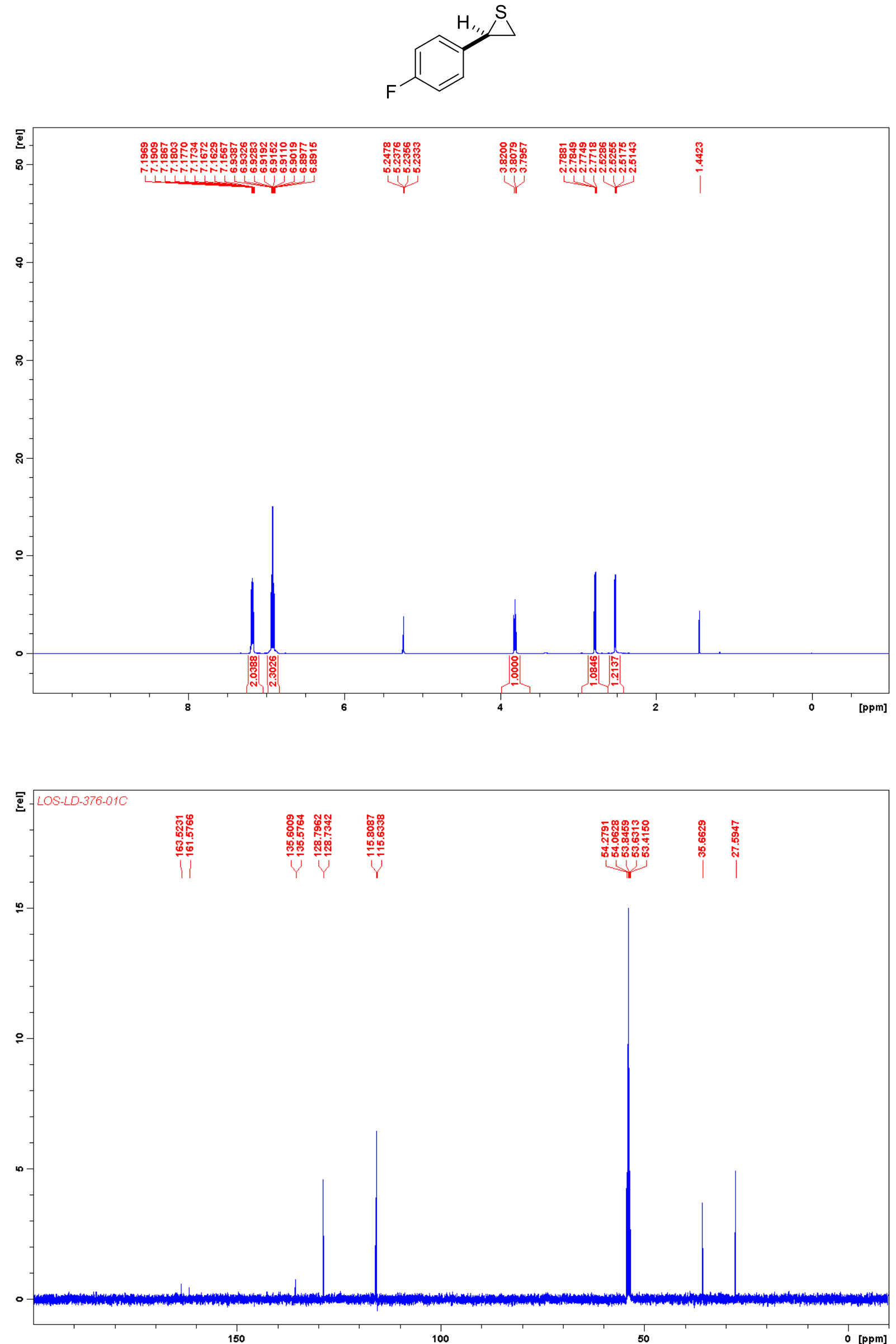


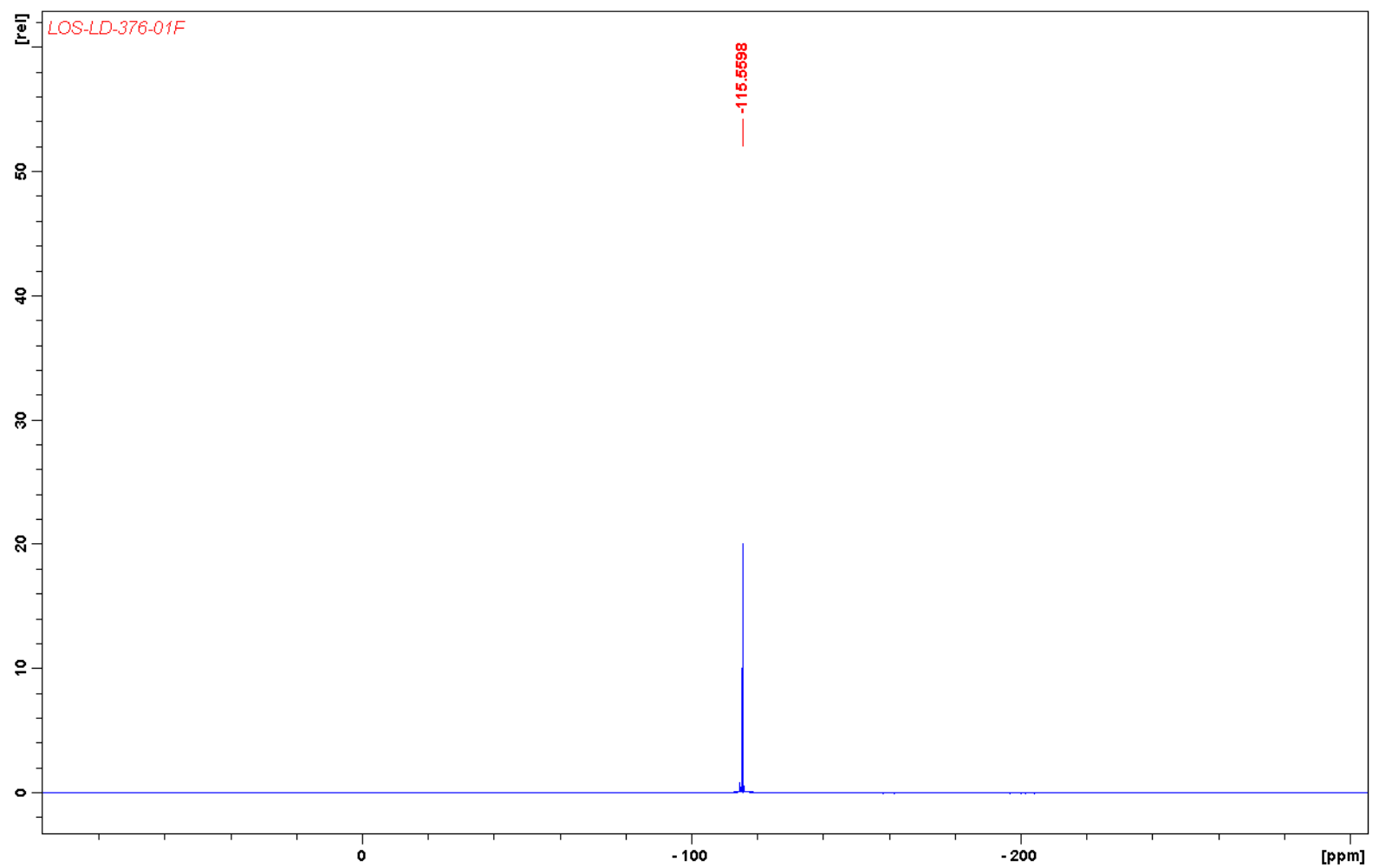



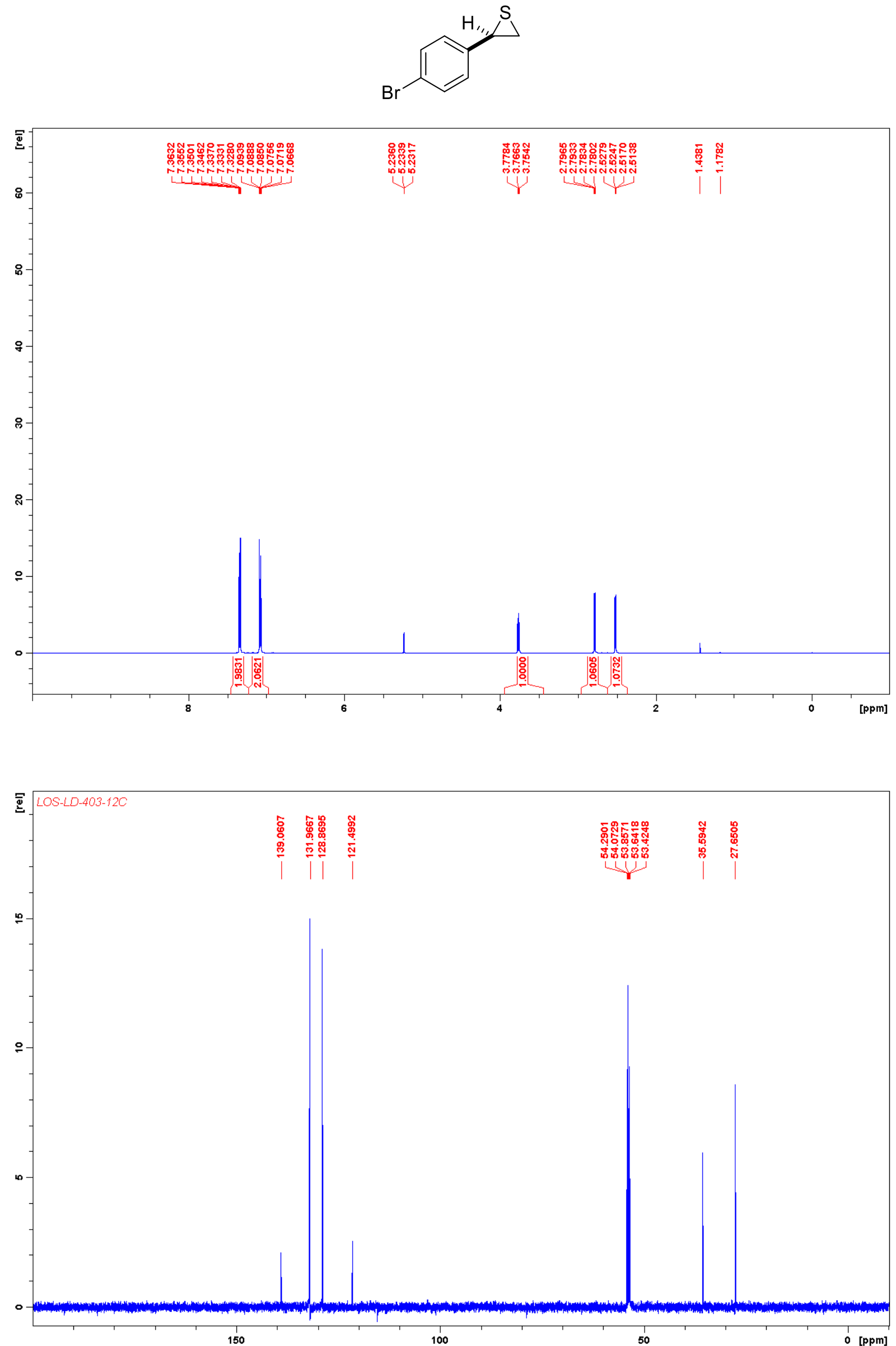

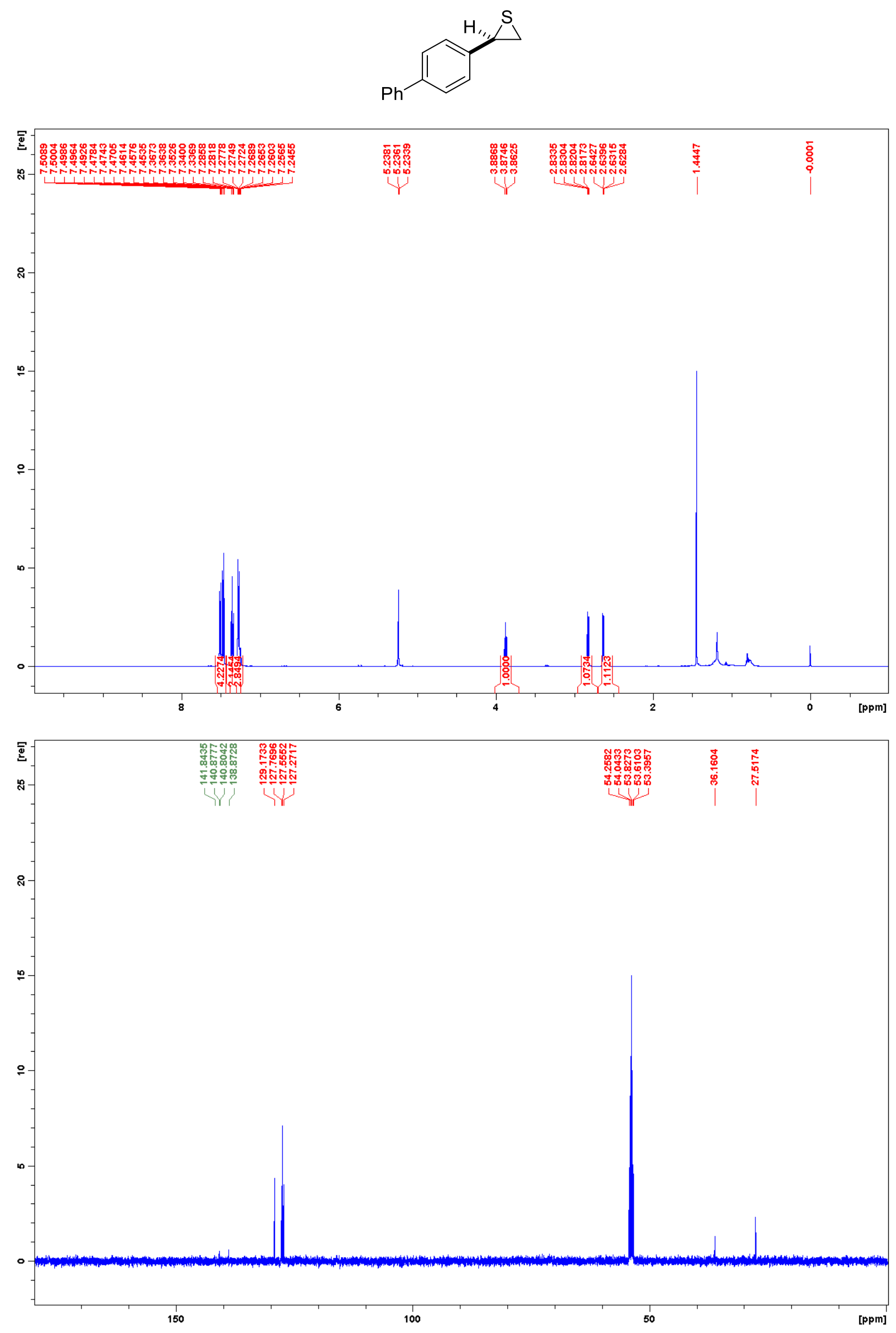

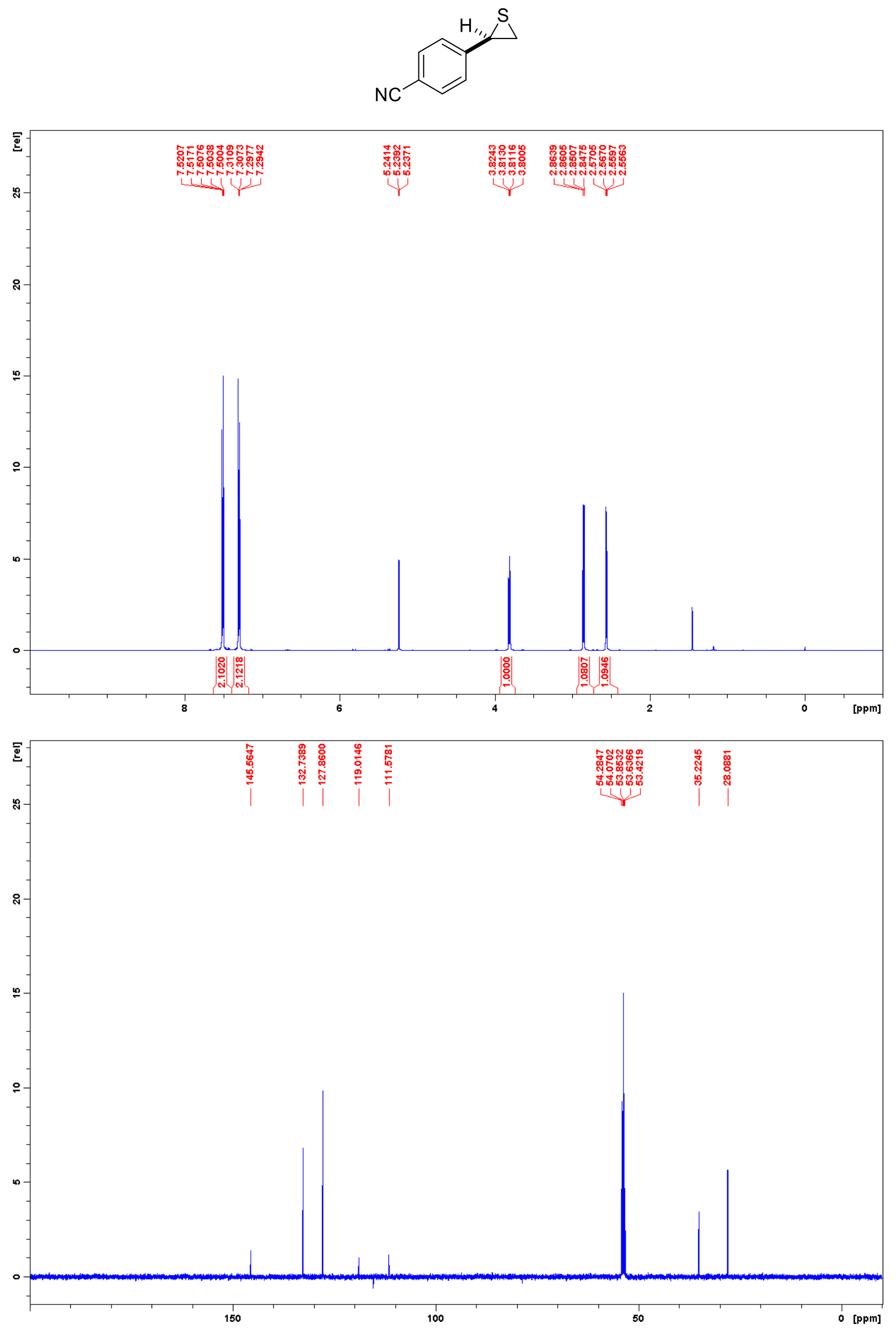

S60 

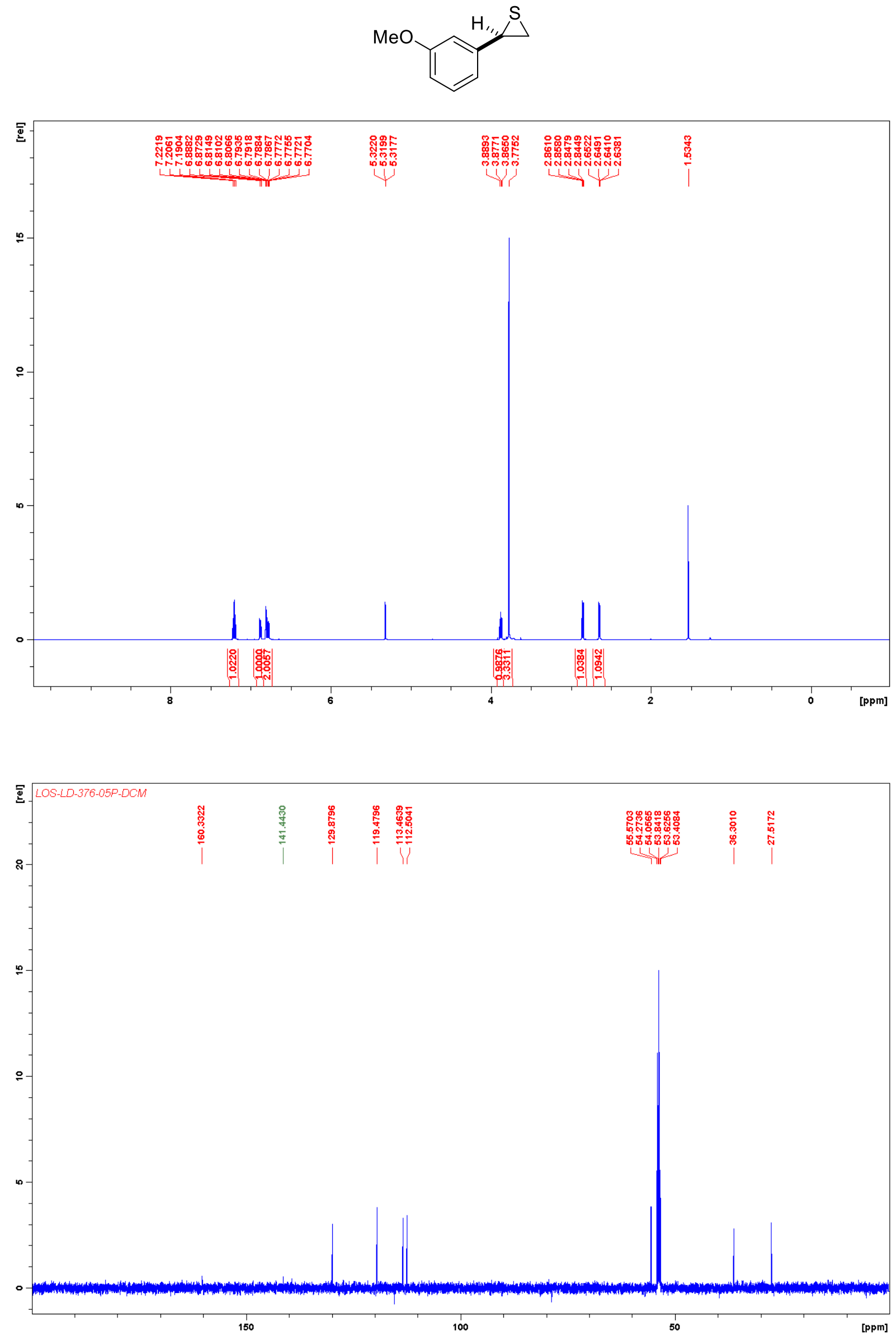

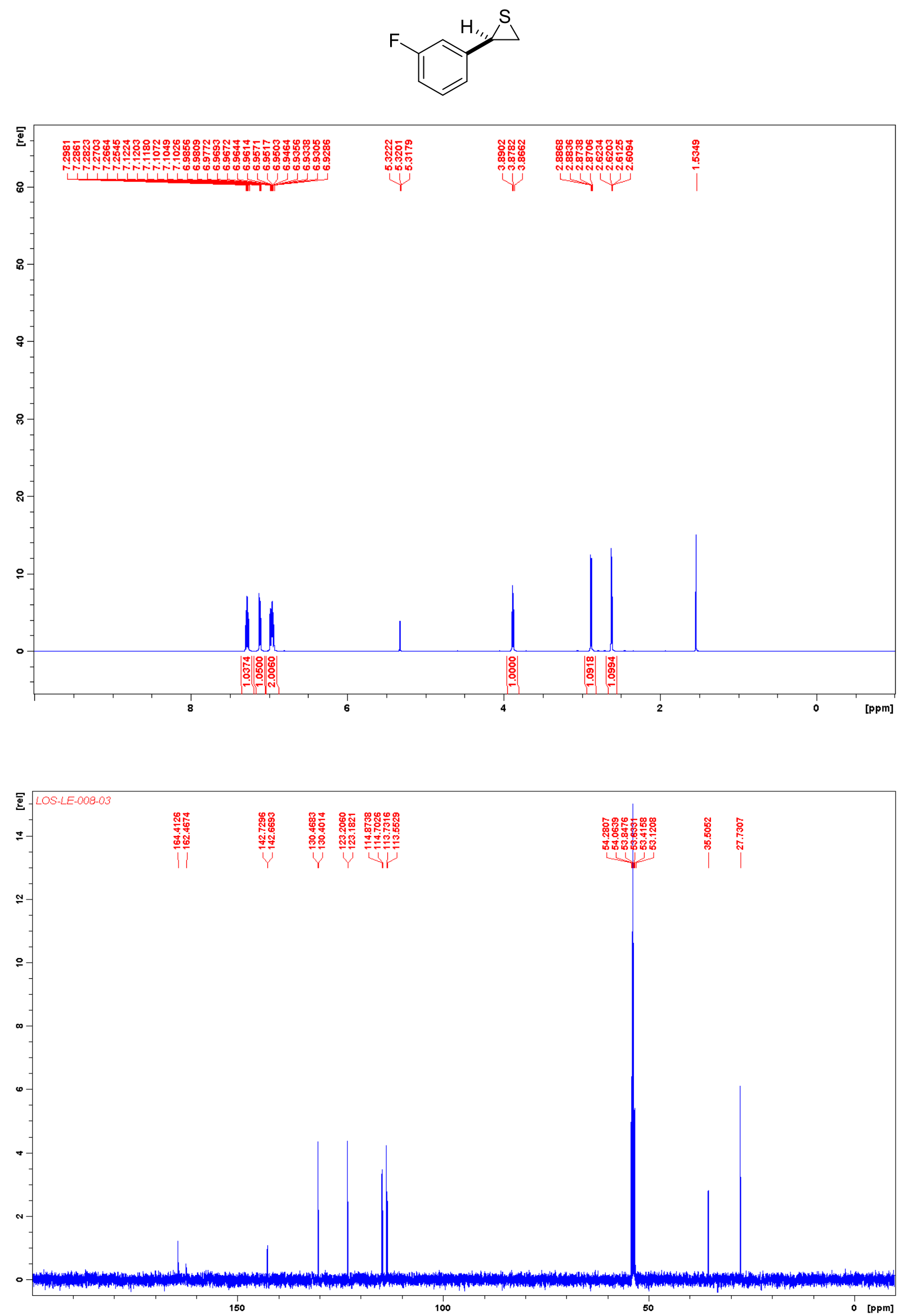


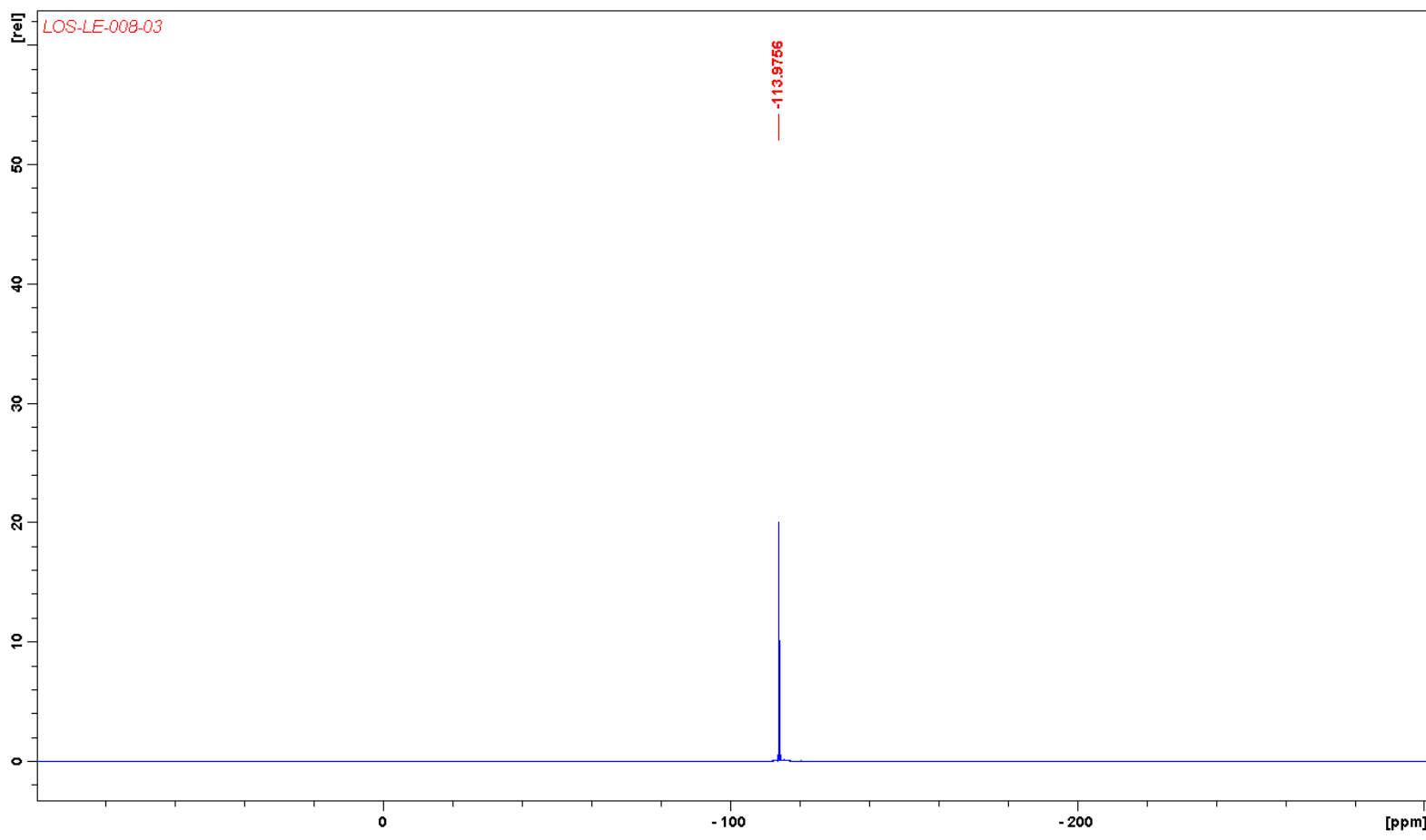

19F NMR 300M Hz 

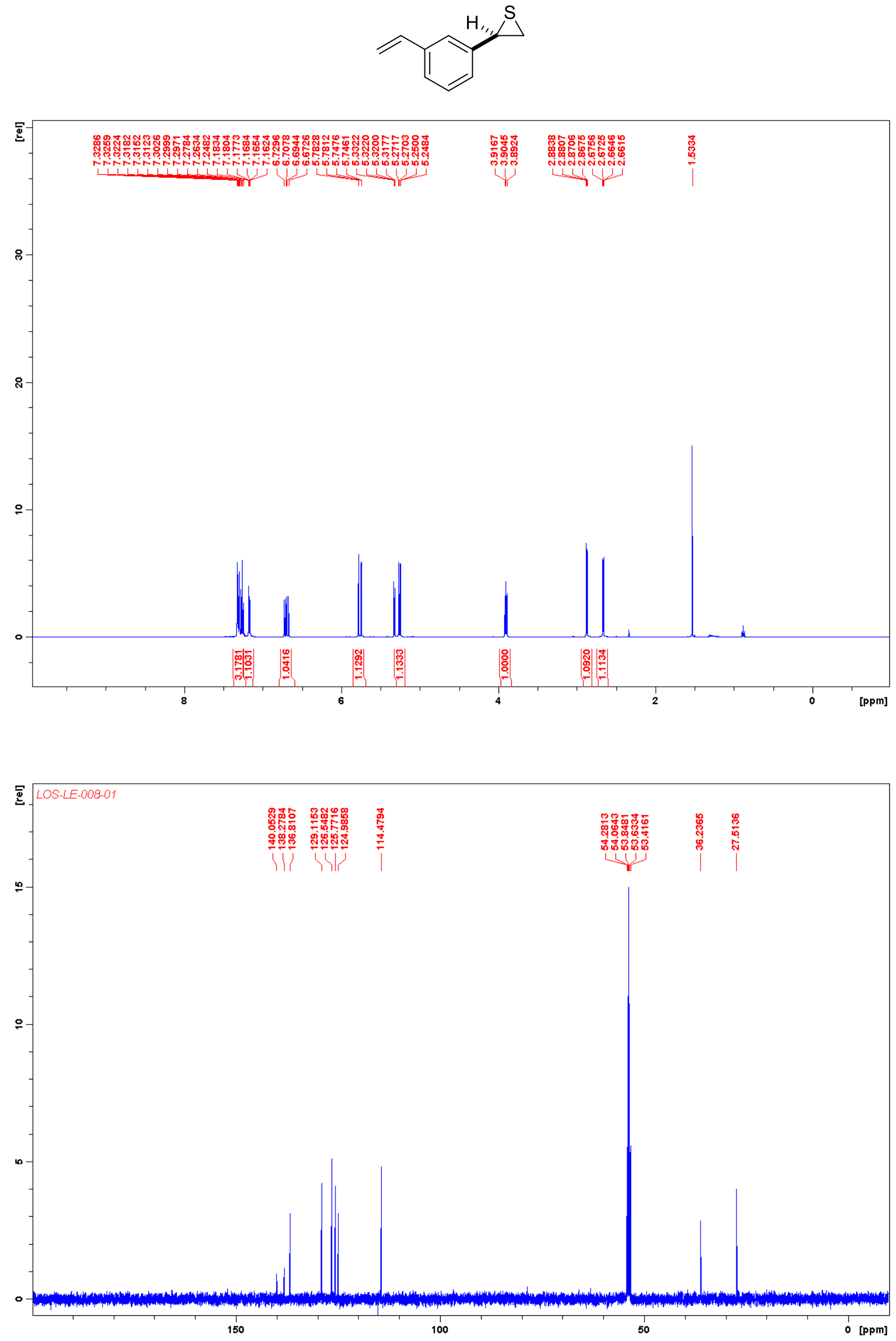

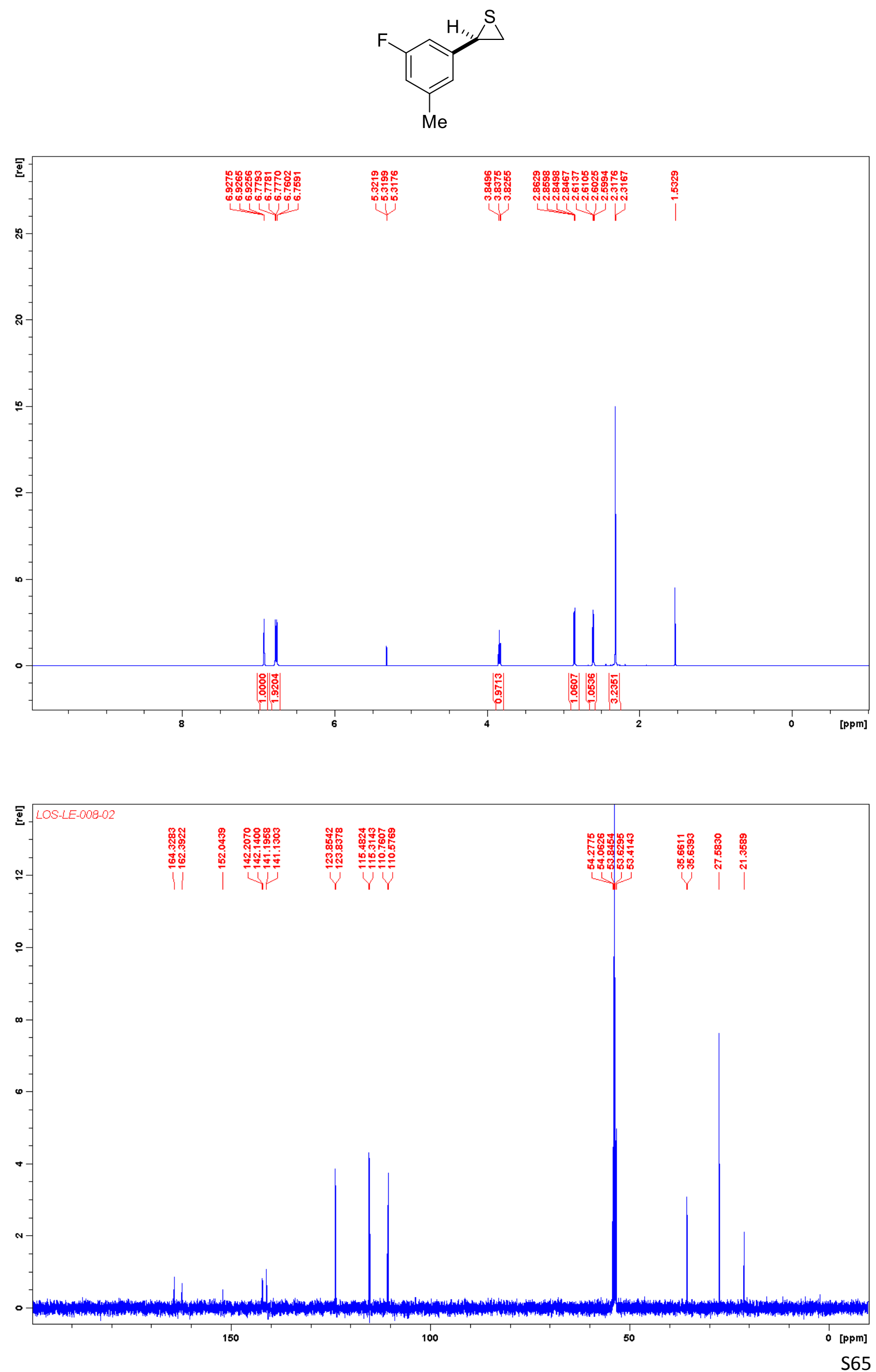


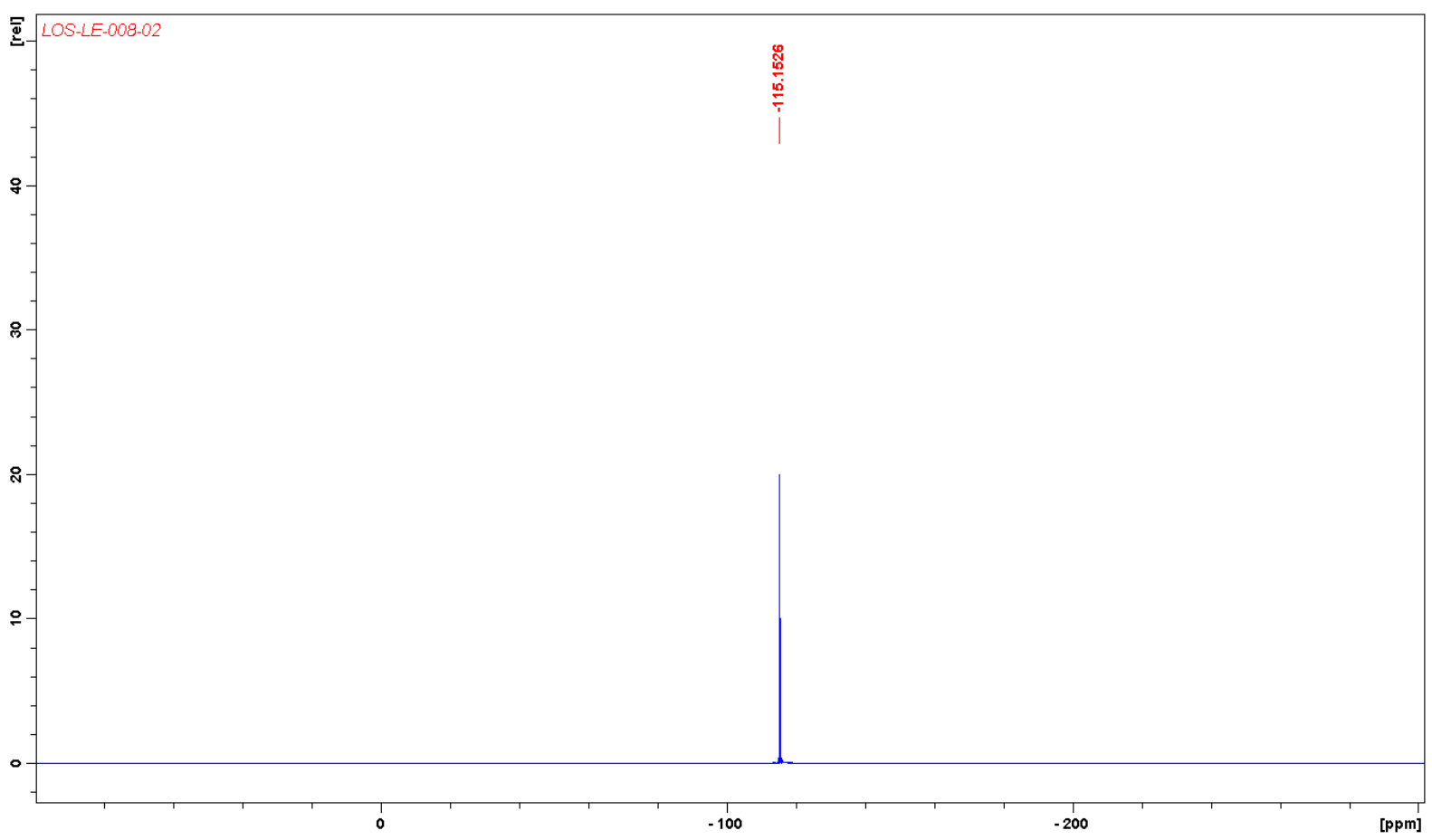

19F NMR 300M Hz 
<smiles>Clc1ccccc1[C@@H]1CS1</smiles>
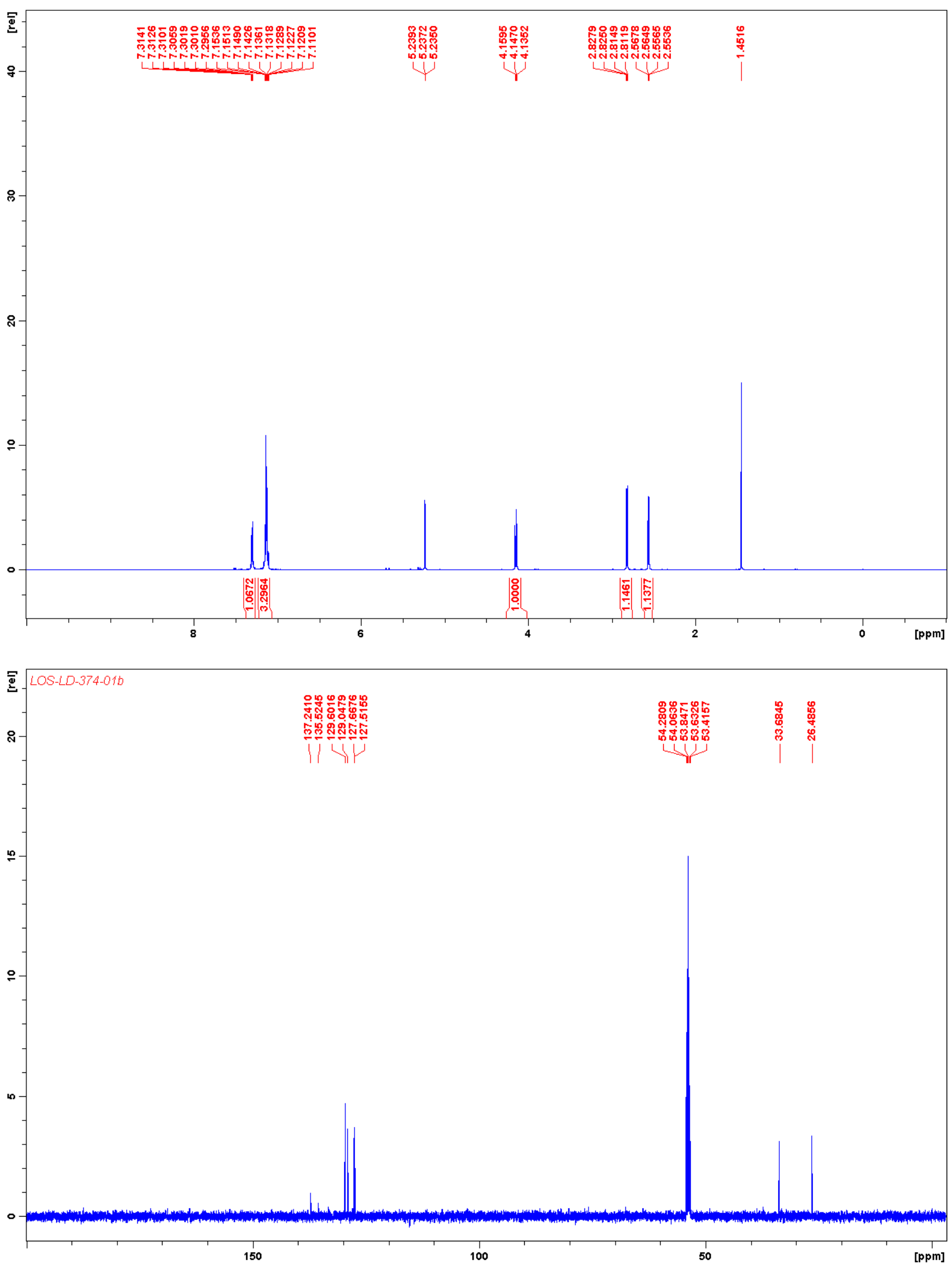
<smiles>Cc1cc(C)c([C@H]2CS2)c(C)c1</smiles>
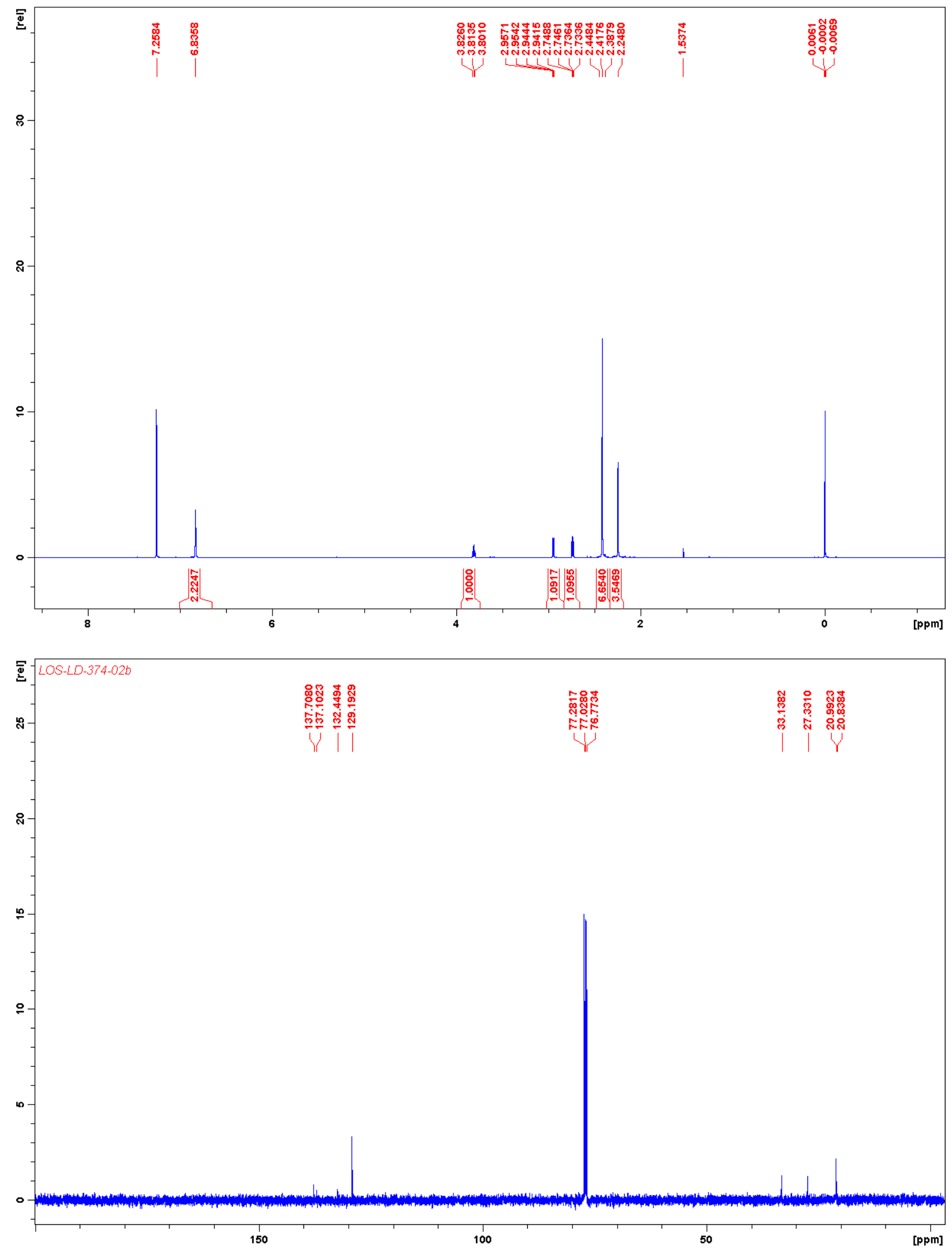

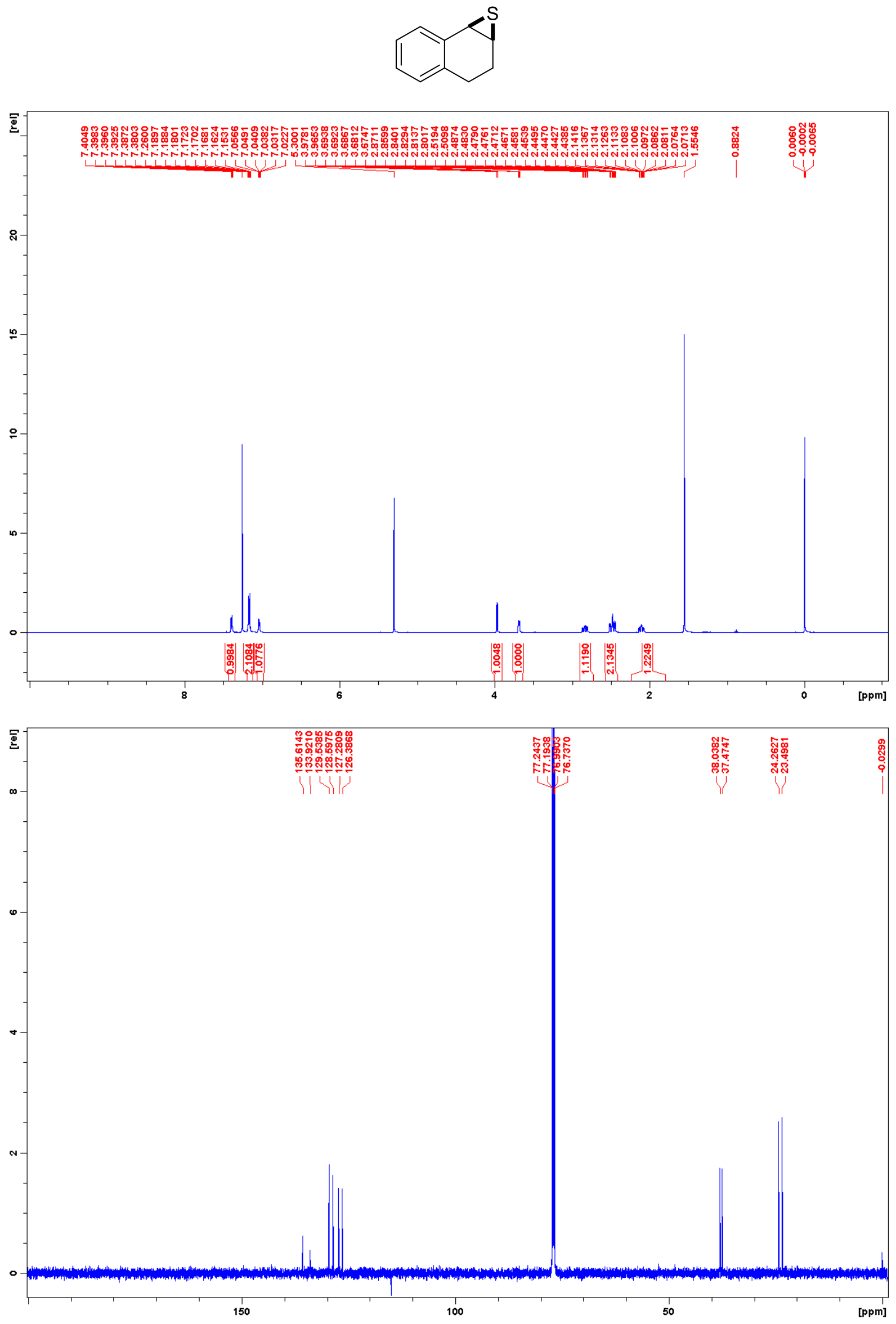

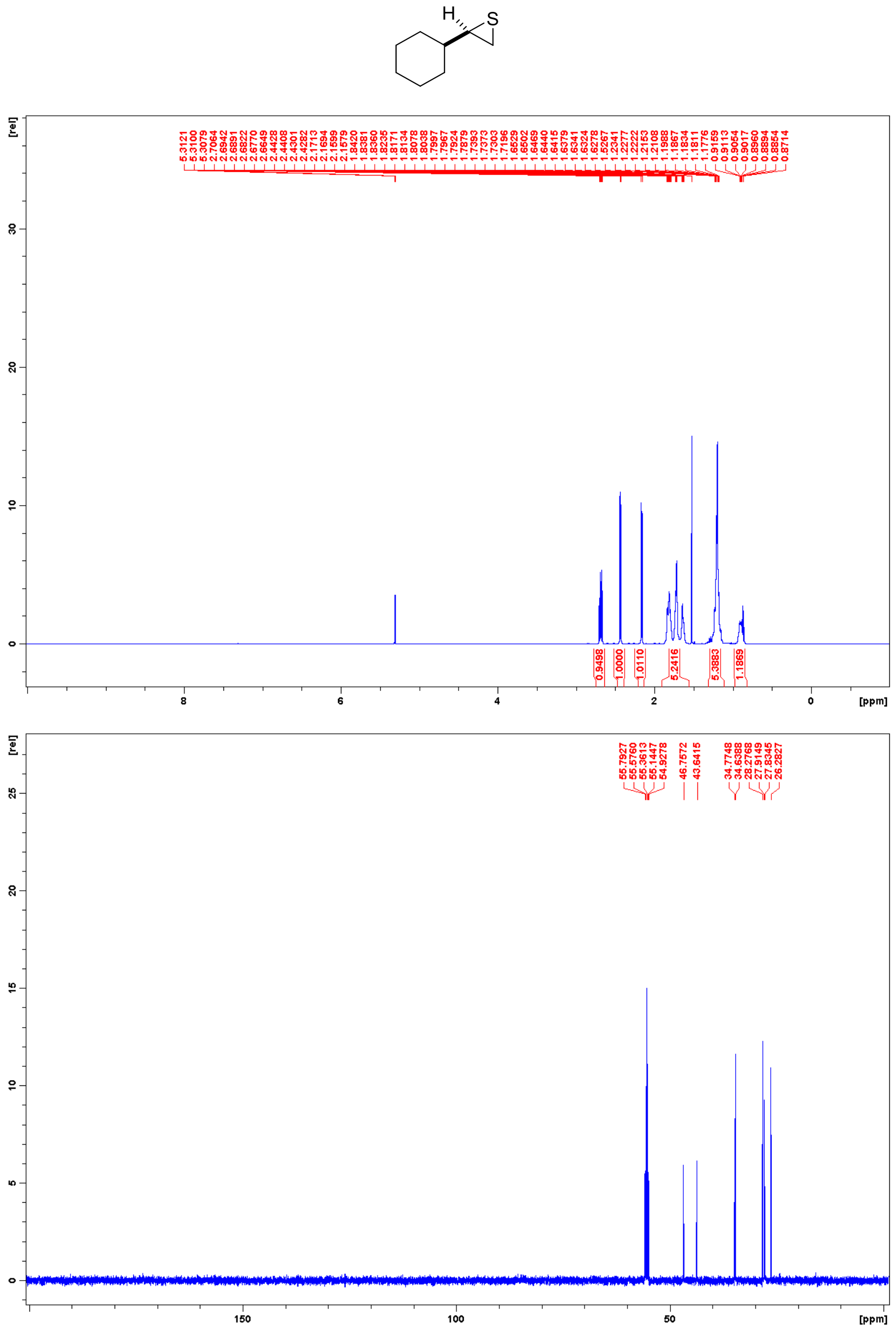

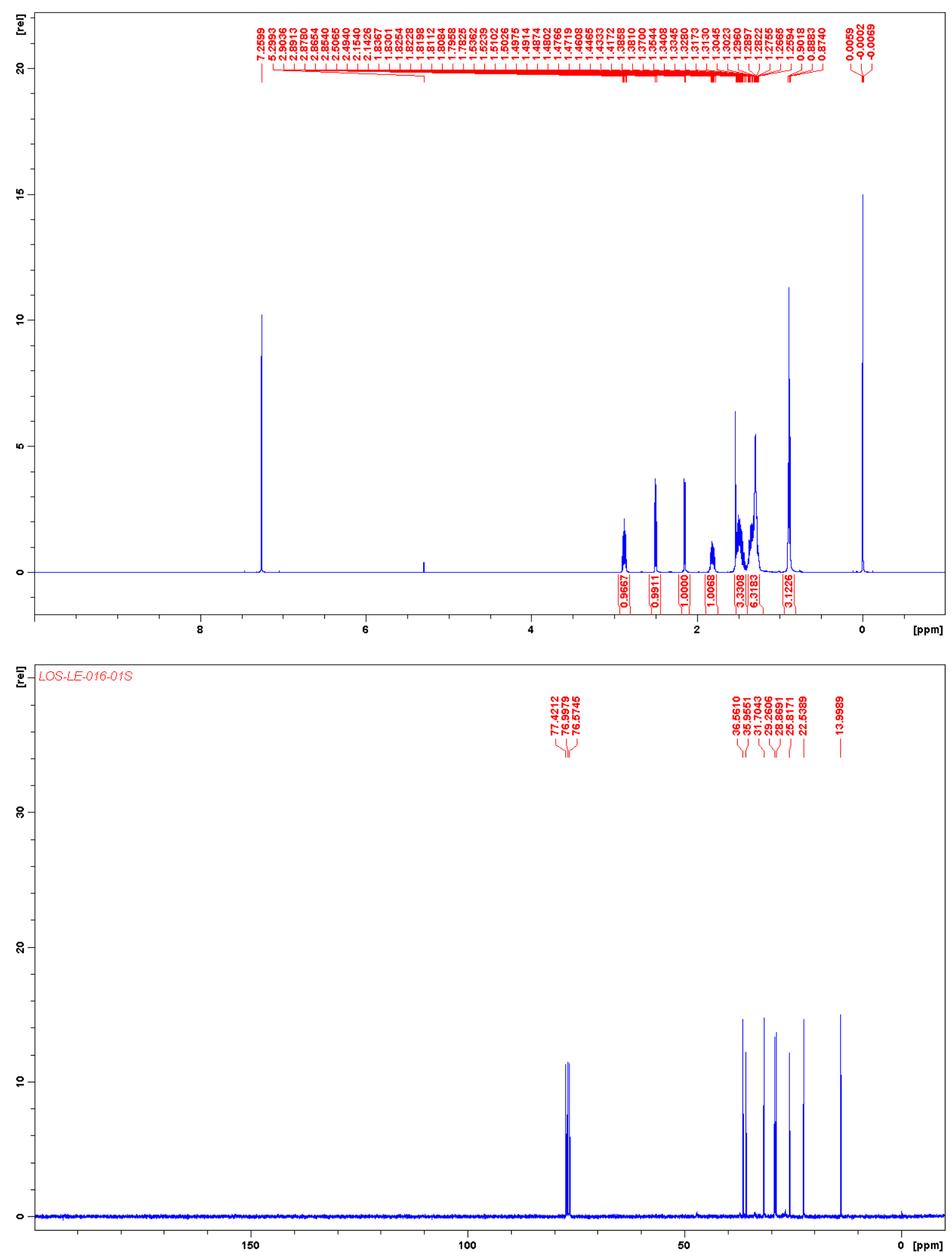

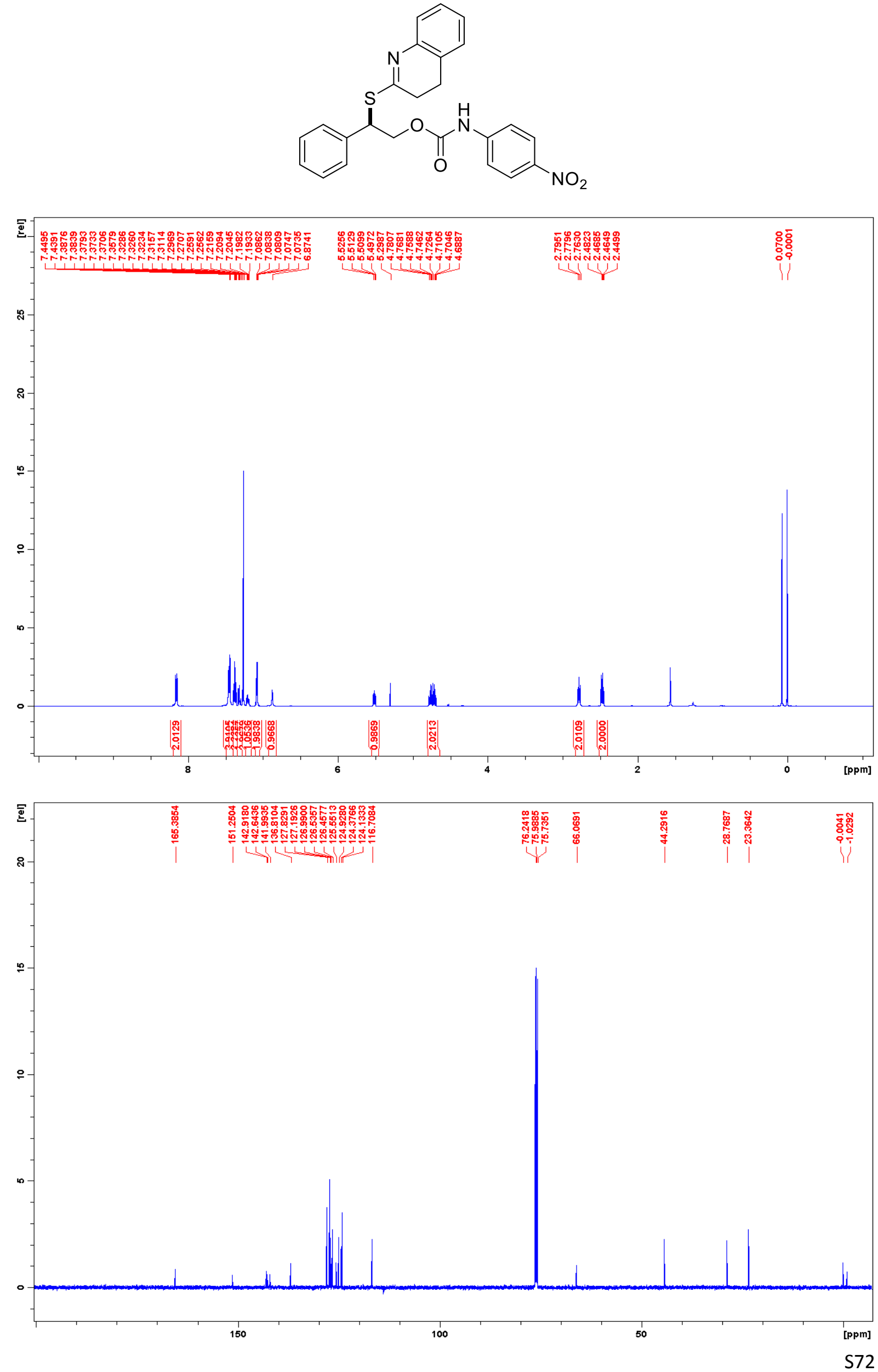


\section{HPLC traces:}

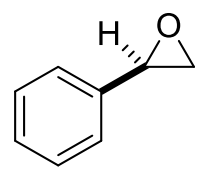

mAU

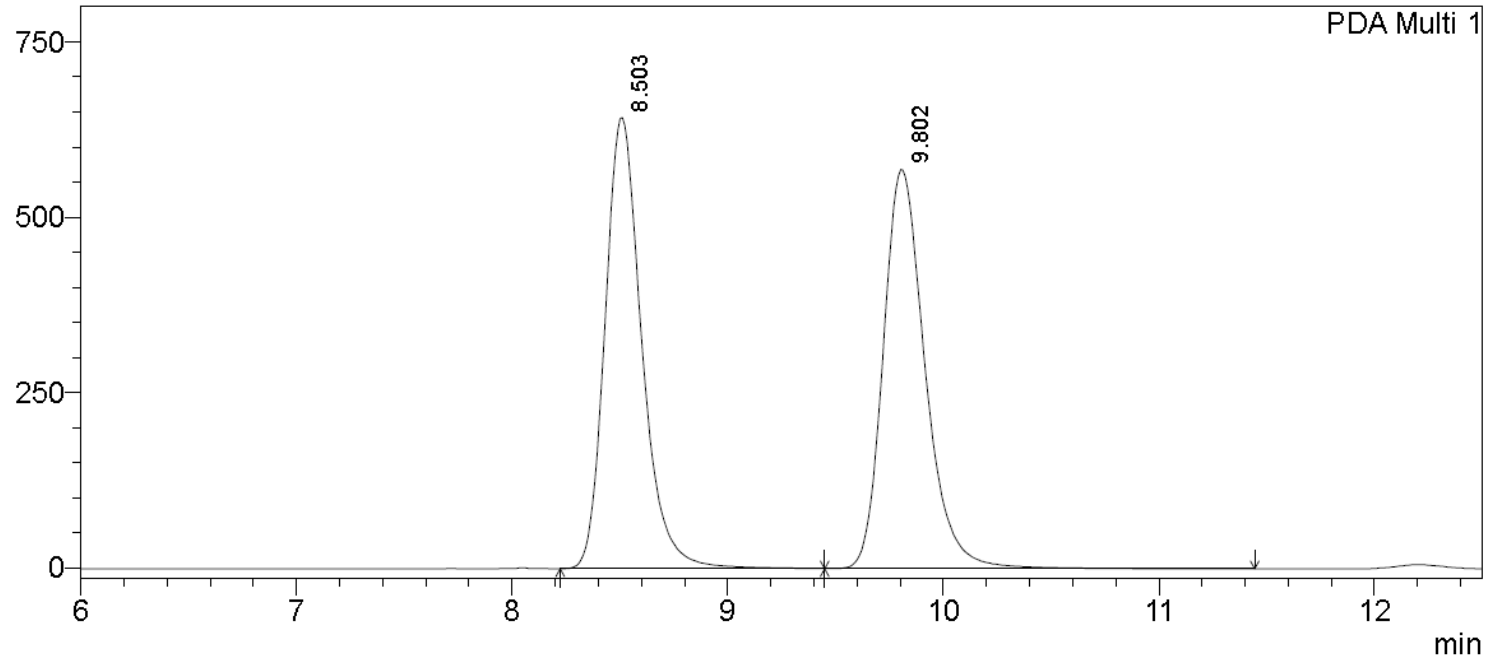

1 PDA Multi $1 / 205 \mathrm{~nm} 4 \mathrm{~nm}$

PeakTable

PDA Ch1 $205 \mathrm{~nm} 4 \mathrm{~nm}$
\begin{tabular}{|r|r|r|r|}
\hline Peak\# & Ret. Time & Area & \multicolumn{1}{|c|}{ Area $\%$} \\
\hline 1 & 8.503 & 7639657 & 49.858 \\
\hline 2 & 9.802 & 7683037 & 50.142 \\
\hline Total & & 15322694 & 100.000 \\
\hline
\end{tabular}

mAU

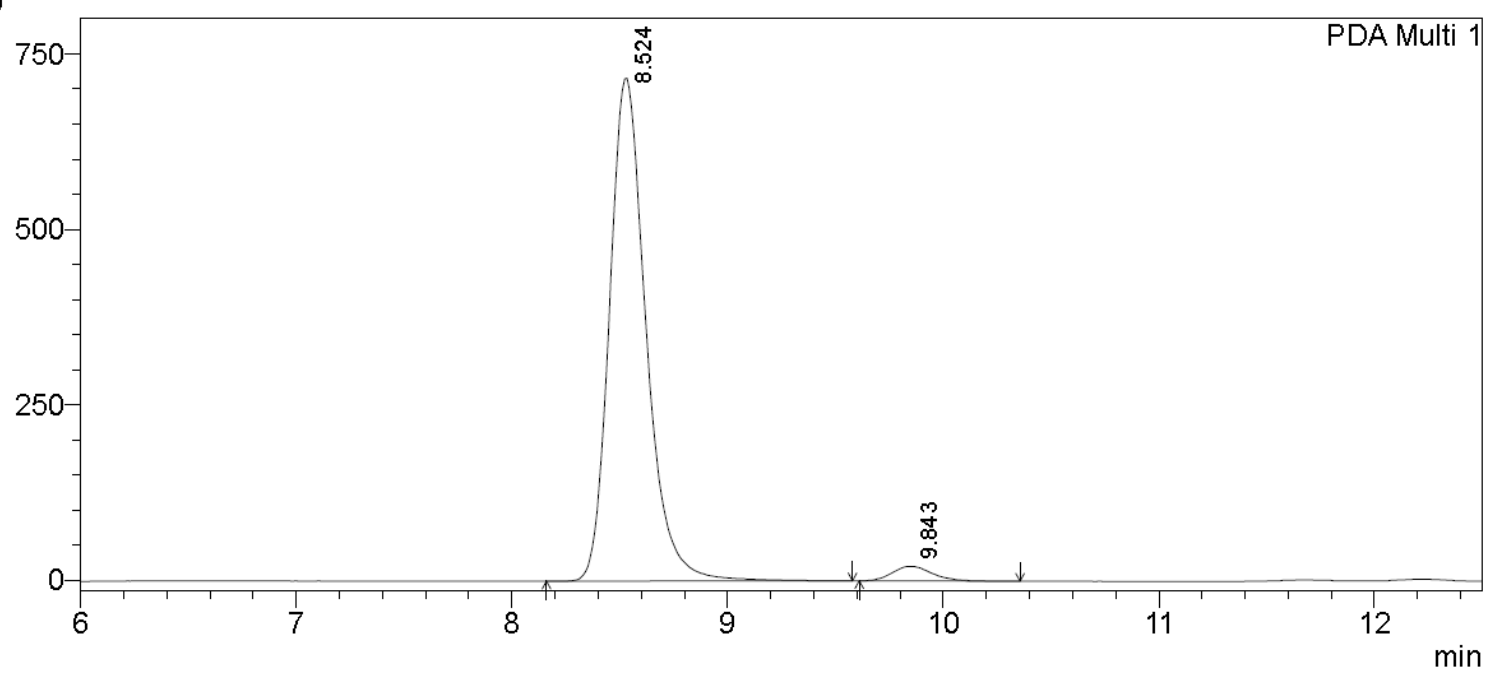

1 PDA Multi $1 / 205 \mathrm{~nm} 4 \mathrm{~nm}$

PeakTable

PDA Ch1 205nm 4nm

\begin{tabular}{|r|r|r|r|}
\hline \multicolumn{1}{|c|}{ Peak\# } & Ret. Time & \multicolumn{1}{c|}{ Area } & \multicolumn{1}{c|}{ Area \% } \\
\hline 1 & 8.524 & 8434468 & 96.910 \\
\hline 2 & 9.843 & 268973 & 3.090 \\
\hline Total & & 8703441 & 100.000 \\
\hline
\end{tabular}



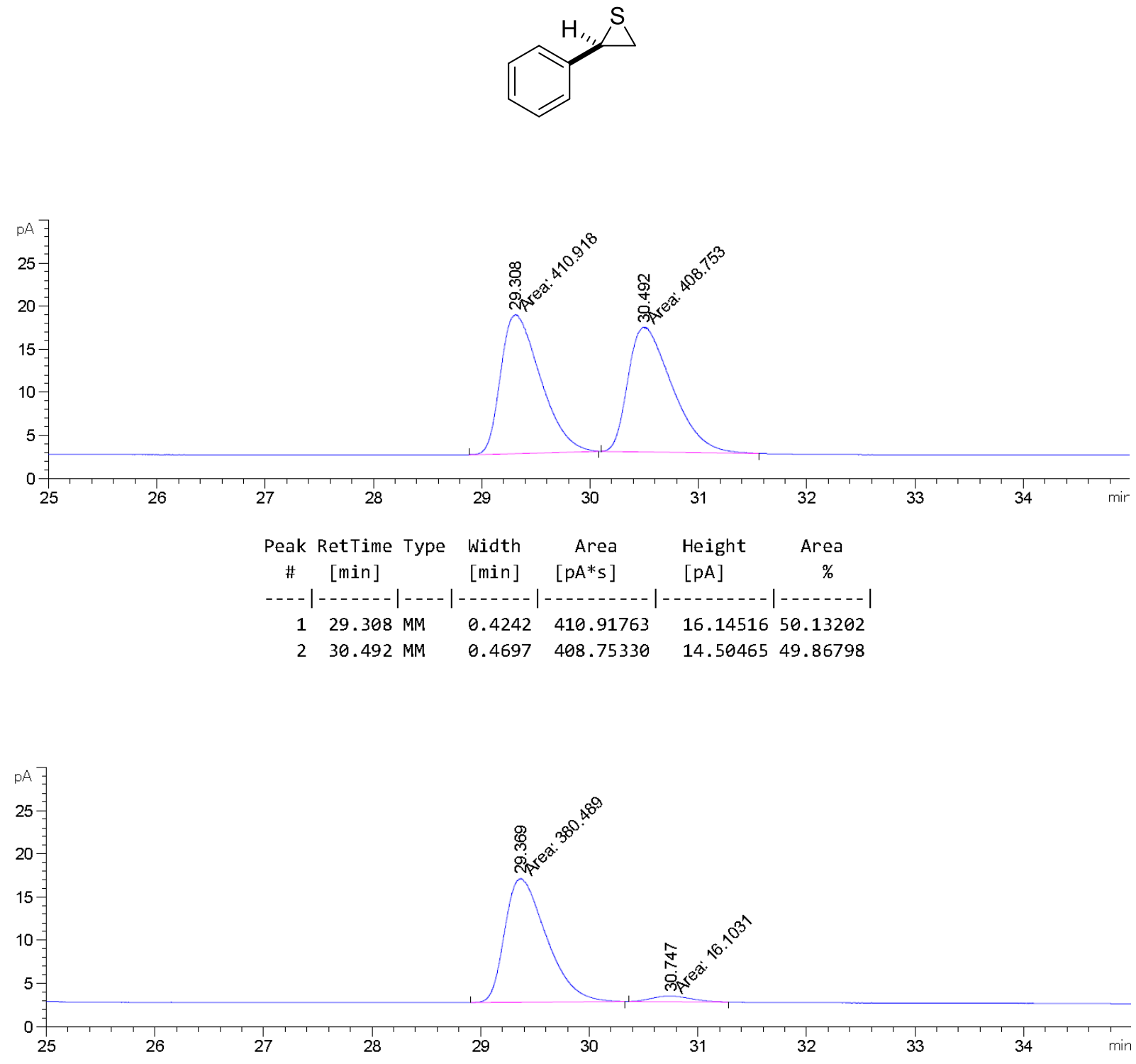

\begin{tabular}{|c|c|c|c|c|c|}
\hline $\begin{array}{c}\text { Peak } \\
\#\end{array}$ & $\begin{array}{l}\text { RetTime Type } \\
\text { [min] }\end{array}$ & $\begin{array}{l}\text { Width } \\
\text { [min] }\end{array}$ & $\begin{array}{r}\text { Area } \\
{\left[\mathrm{pA}^{*} \mathrm{~s}\right]}\end{array}$ & $\begin{array}{l}\text { Height } \\
{[\mathrm{pA}]}\end{array}$ & $\begin{array}{c}\text { Area } \\
\%\end{array}$ \\
\hline & & & & & 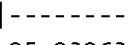 \\
\hline 1 & $29.369 \mathrm{MM}$ & 0.4423 & 380.48862 & 14.33714 & 95.93963 \\
\hline 2 & $30.747 \mathrm{MM}$ & 0.4161 & 16.10309 & $6.45064 \mathrm{e}-1$ & 4.06037 \\
\hline
\end{tabular}


<smiles>CC(=O)Oc1ccc(C2CO2)cc1</smiles>

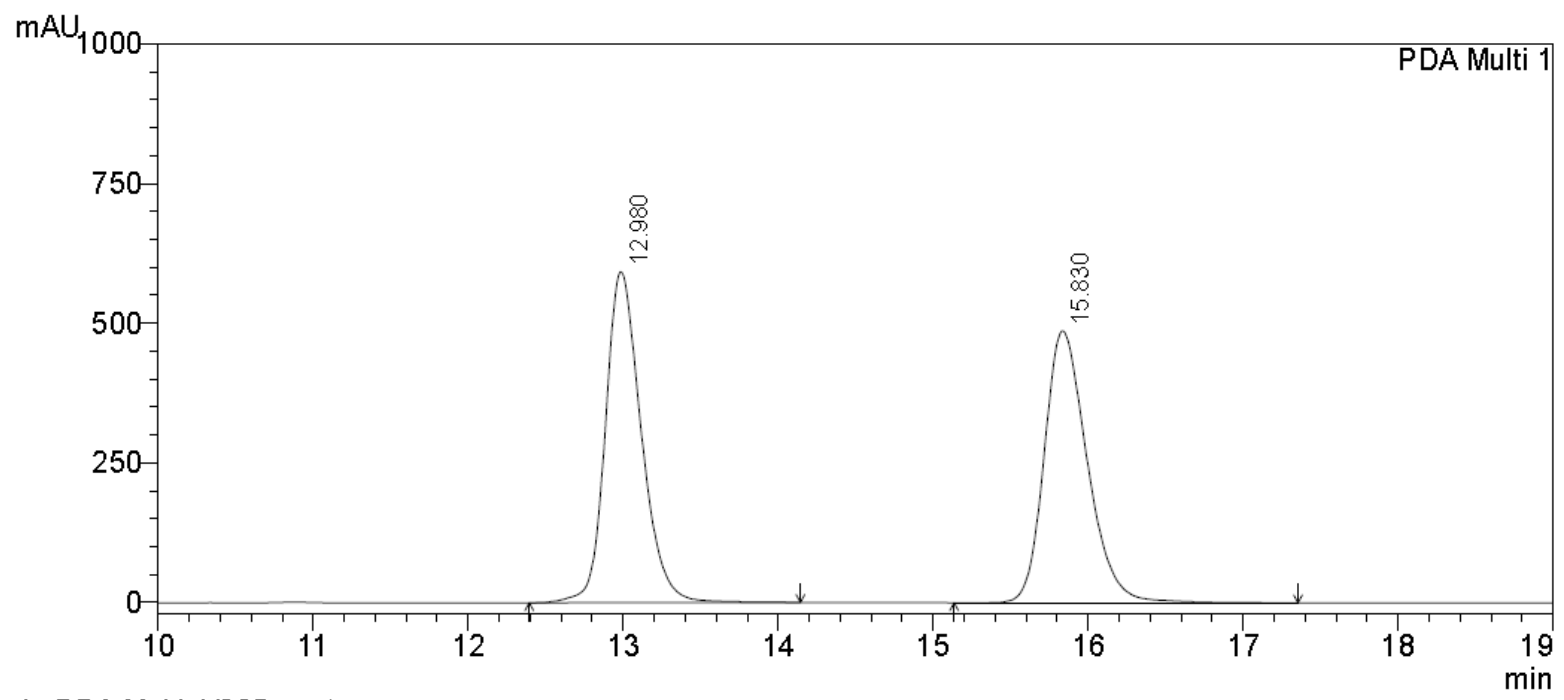

1 PDA Multi $1 / 205 \mathrm{~nm} 4 \mathrm{~nm}$

PDA Ch1 205nm 4nm

PeakTable

\begin{tabular}{|r|r|r|r|}
\hline \multicolumn{1}{|c|}{ Peak\# } & Ret. Time & \multicolumn{1}{|c|}{ Area } & \multicolumn{1}{|c|}{ Area \% } \\
\hline 1 & 12.980 & 9525029 & 50.387 \\
\hline 2 & 15.830 & 9378706 & 49.613 \\
\hline Total & & 18903735 & 100.000 \\
\hline
\end{tabular}

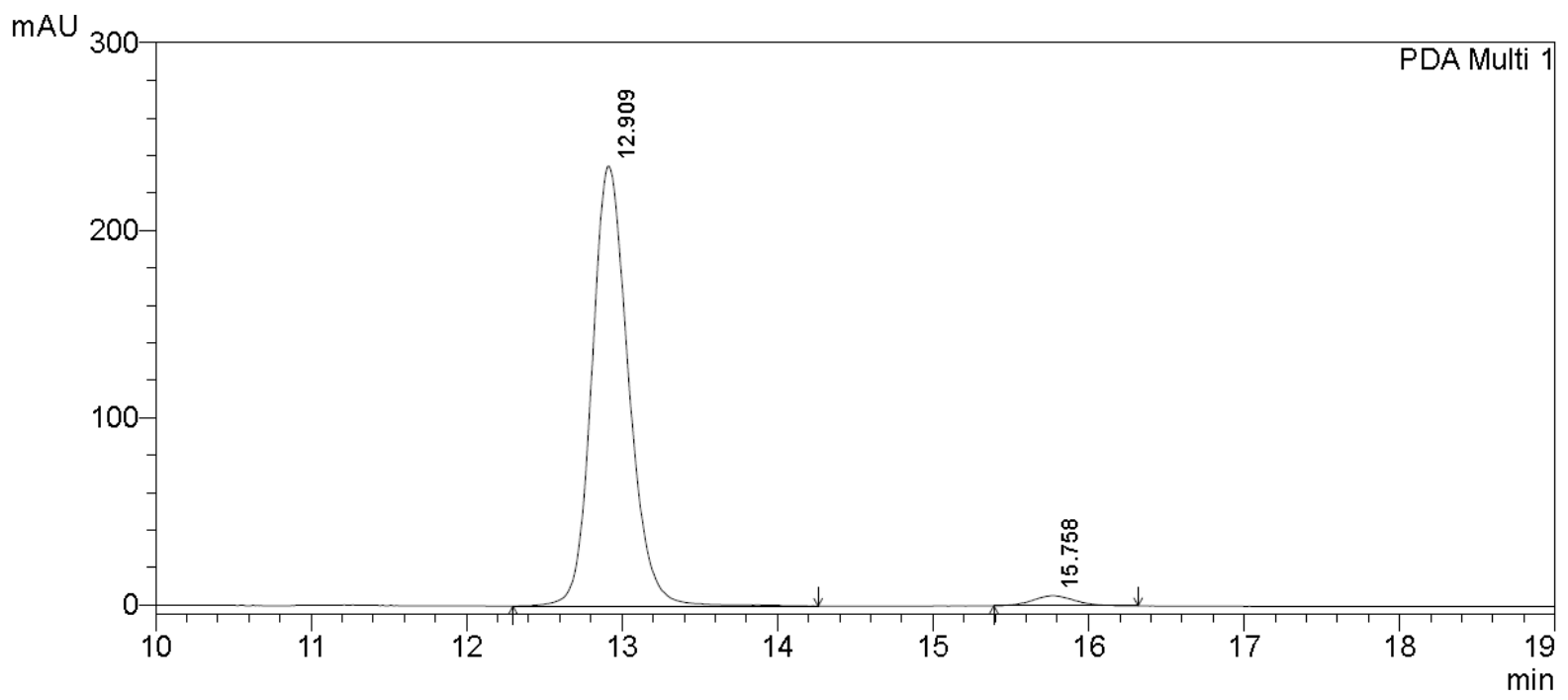

1 PDA Multi 1/205nm 4nm

PeakTable

PDA Ch1 205nm 4nm

\begin{tabular}{|r|r|r|r|}
\hline \multicolumn{1}{|c|}{ Peak\# } & Ret. Time & \multicolumn{1}{|c|}{ Area } & \multicolumn{1}{c|}{ Area \% } \\
\hline 1 & 12.909 & 3841707 & 97.450 \\
\hline 2 & 15.758 & 100544 & 2.550 \\
\hline Total & & 3942251 & 100.000 \\
\hline
\end{tabular}


<smiles>CC(=O)Oc1ccc([C@H]2CS2)cc1</smiles>

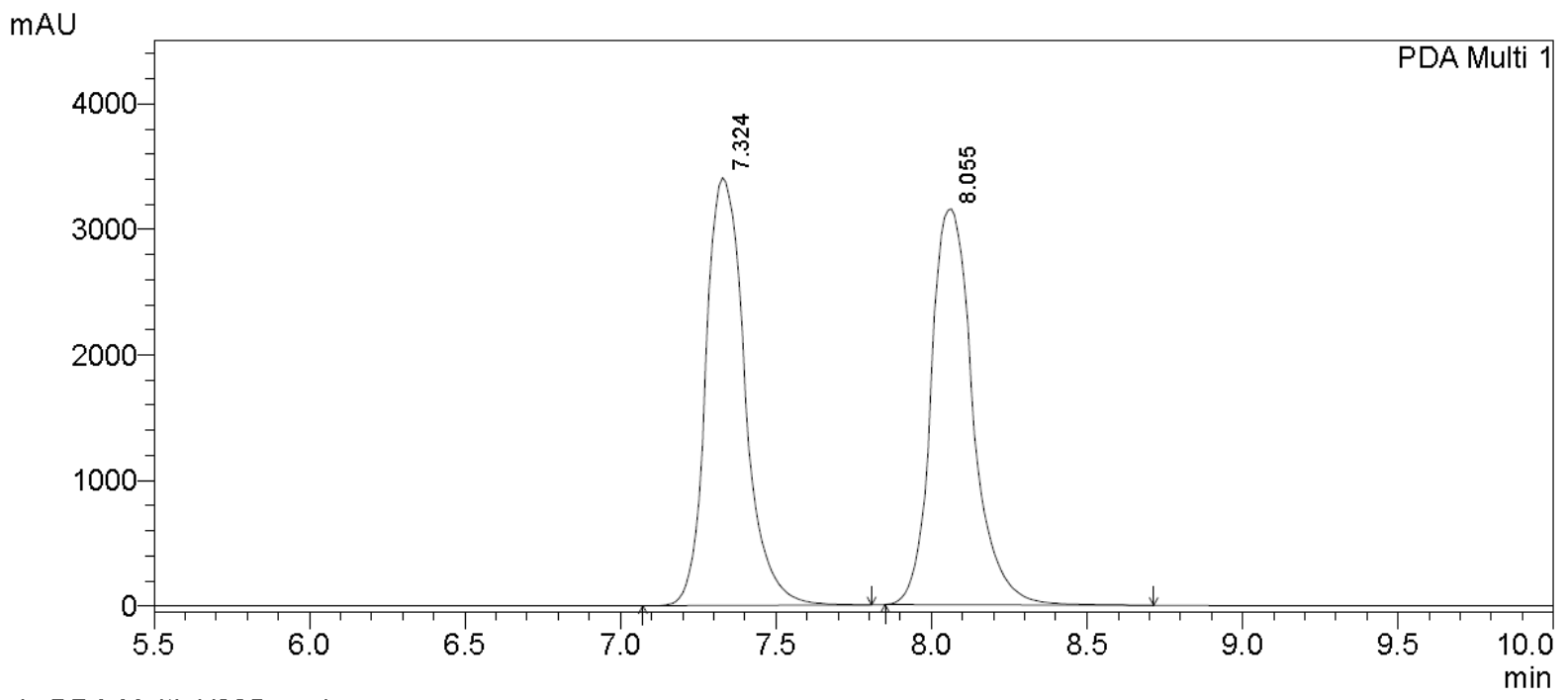

1 PDA Multi $1 / 205 \mathrm{~nm} 4 \mathrm{~nm}$

PeakTable

PDA Ch1 $205 \mathrm{~nm} 4 \mathrm{~nm}$
\begin{tabular}{|r|r|r|r|}
\hline Peak\# & Ret. Time & Area & Area \% \\
\hline 1 & 7.324 & 29718387 & 50.161 \\
\hline 2 & 8.055 & 29527549 & 49.839 \\
\hline Total & & 59245936 & 100.000 \\
\hline
\end{tabular}

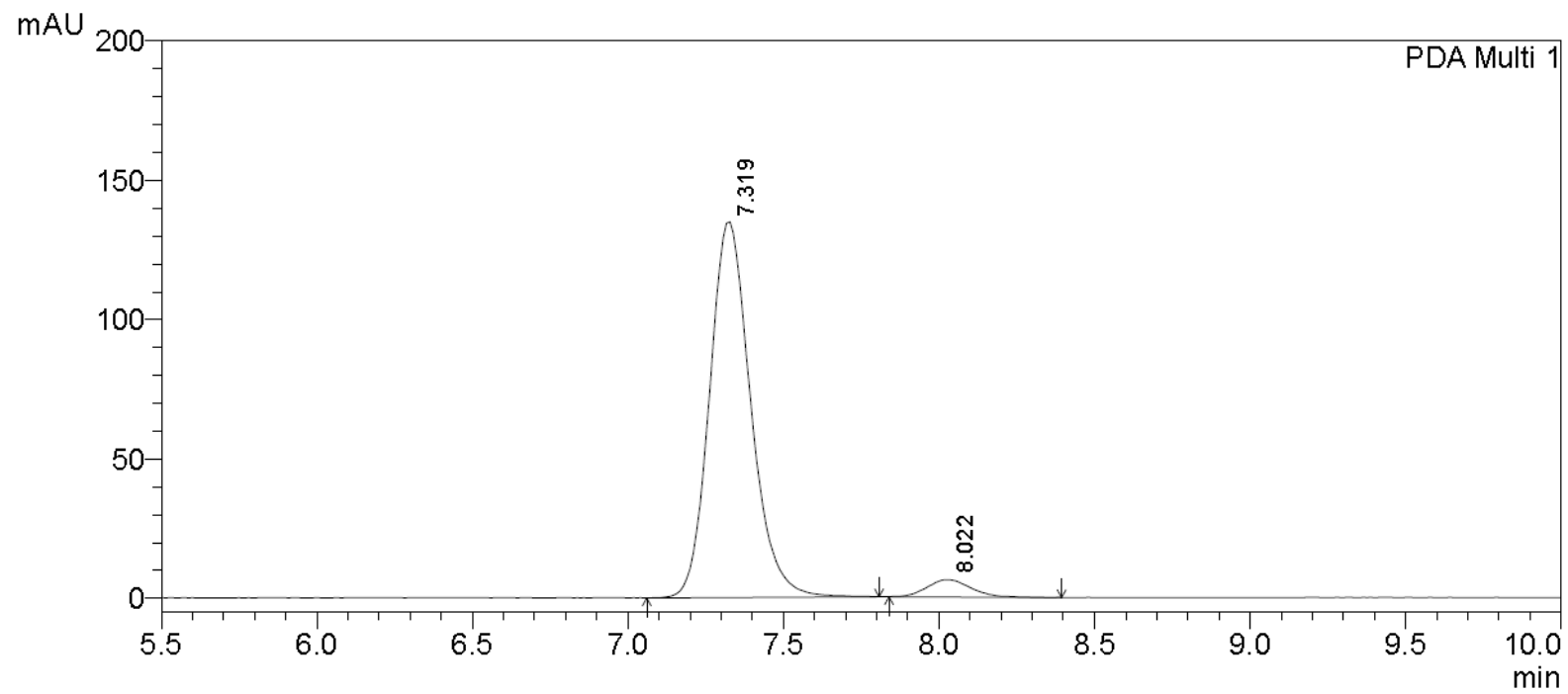

1 PDA Multi $1 / 205 \mathrm{~nm} 4 \mathrm{~nm}$

PeakTable

PDA Ch1 205nm 4nm

\begin{tabular}{|r|r|r|r|}
\hline Peak\# & Ret. Time & \multicolumn{1}{|c|}{ Area } & \multicolumn{1}{|c|}{ Area \% } \\
\hline 1 & 7.319 & 1240350 & 95.379 \\
\hline 2 & 8.022 & 60091 & 4.621 \\
\hline Total & & 1300441 & 100.000 \\
\hline
\end{tabular}



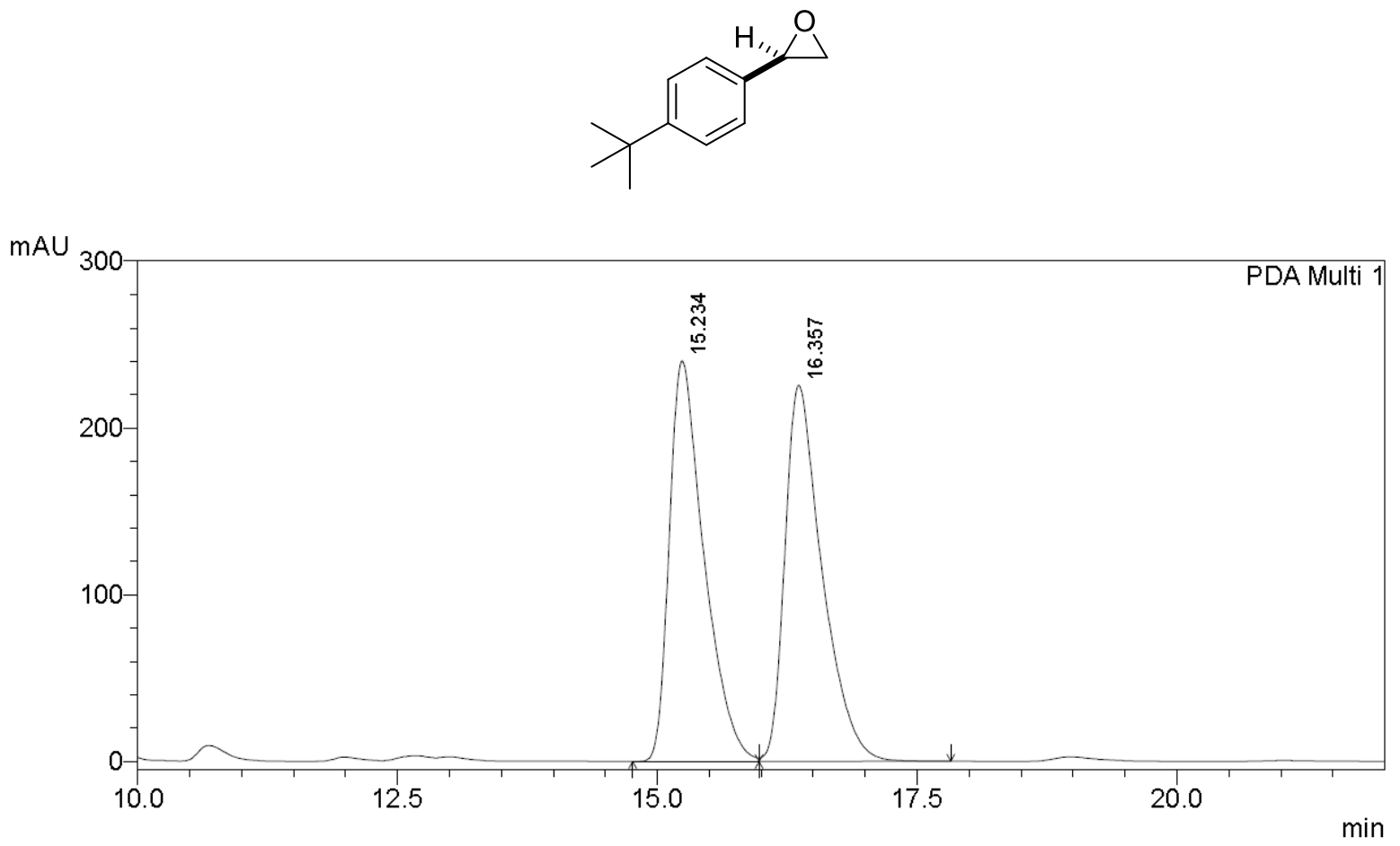

1 PDA Multi 1/230nm 4nm

PeakTable

PDA Ch1 230nm 4nm

\begin{tabular}{|r|r|r|r|}
\hline \multicolumn{1}{|c|}{ Peak\# } & Ret. Time & \multicolumn{1}{|c|}{ Area } & \multicolumn{1}{c|}{ Area \% } \\
\hline 1 & 15.234 & 5575838 & 49.799 \\
\hline 2 & 16.357 & 5620958 & 50.201 \\
\hline Total & & 11196796 & 100.000 \\
\hline
\end{tabular}

mAU

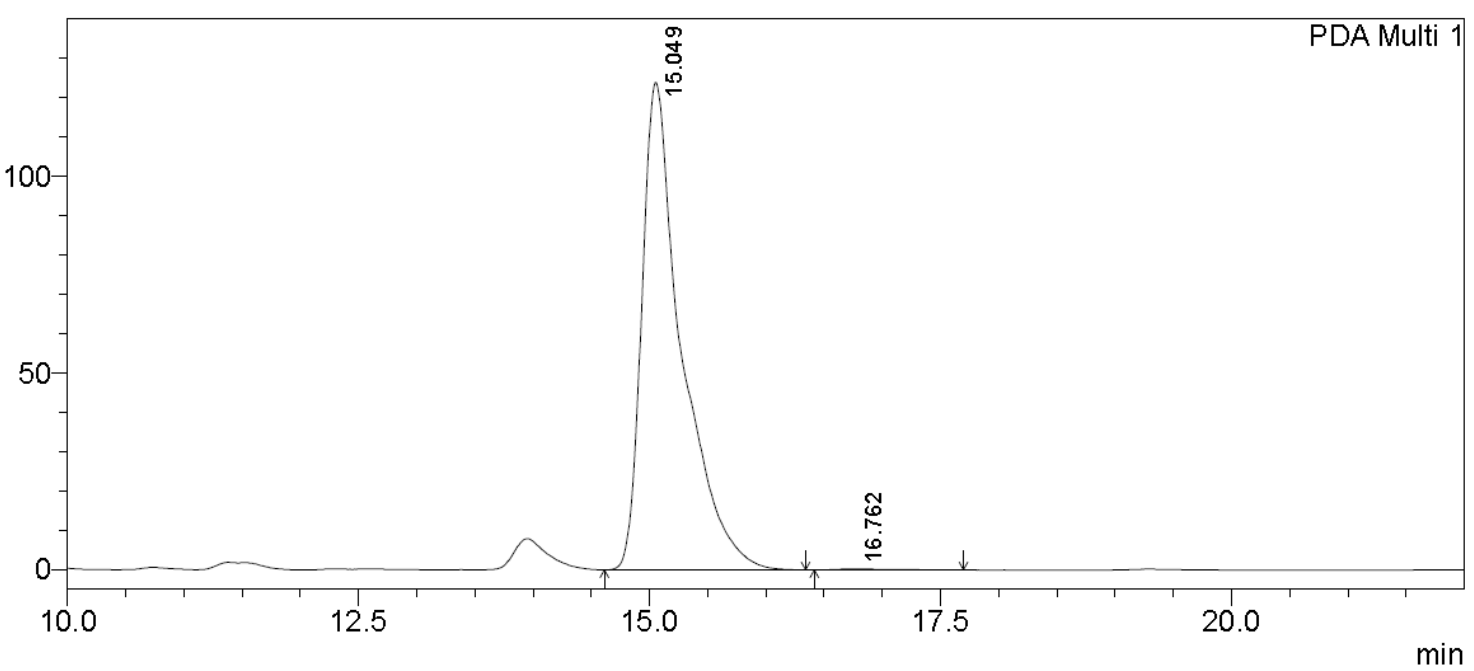

1 PDA Multi 1/230nm 4nm

PeakTable

PDA Ch1 230nm 4nm

\begin{tabular}{|r|r|r|r|}
\hline \multicolumn{1}{|c|}{ Peak\# } & Ret. Time & \multicolumn{1}{|c|}{ Area } & \multicolumn{1}{|c|}{ Area \% } \\
\hline 1 & 15.049 & 2940753 & 99.728 \\
\hline 2 & 16.762 & 8015 & 0.272 \\
\hline Total & & 2948768 & 100.000 \\
\hline
\end{tabular}




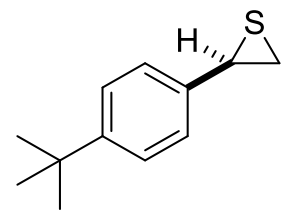

MAU

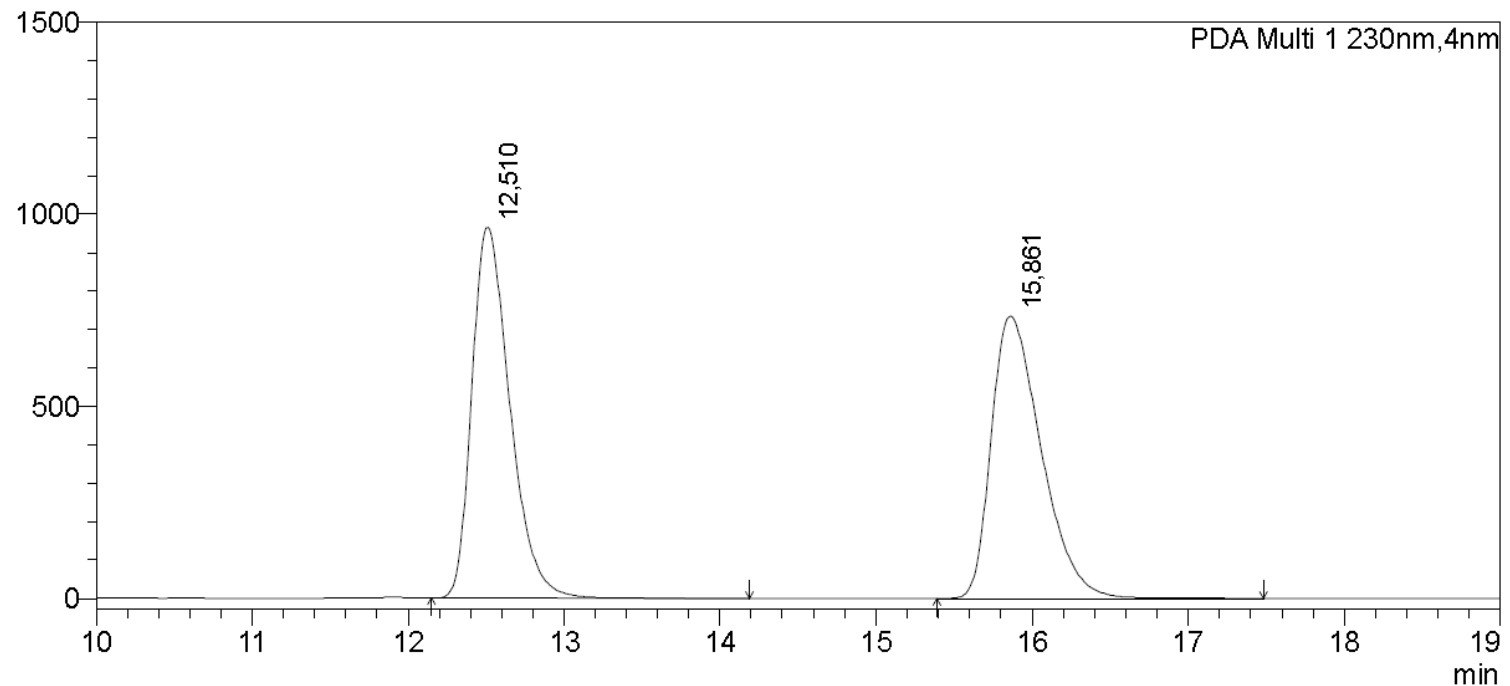

<Peak Table>

\begin{tabular}{|c|c|c|c|c|}
\hline \multicolumn{2}{|c|}{ Peak\# Ret. Time } & & & \\
\hline & Set. & Are & Helght & Area\% \\
\hline 1 & 12,510 & 16369297 & 965784 & 50,016 \\
\hline 2 & 15,861 & 16358601 & 735538 & 49,984 \\
\hline Total & & 32727898 & 1701323 & 100,000 \\
\hline
\end{tabular}

mAU

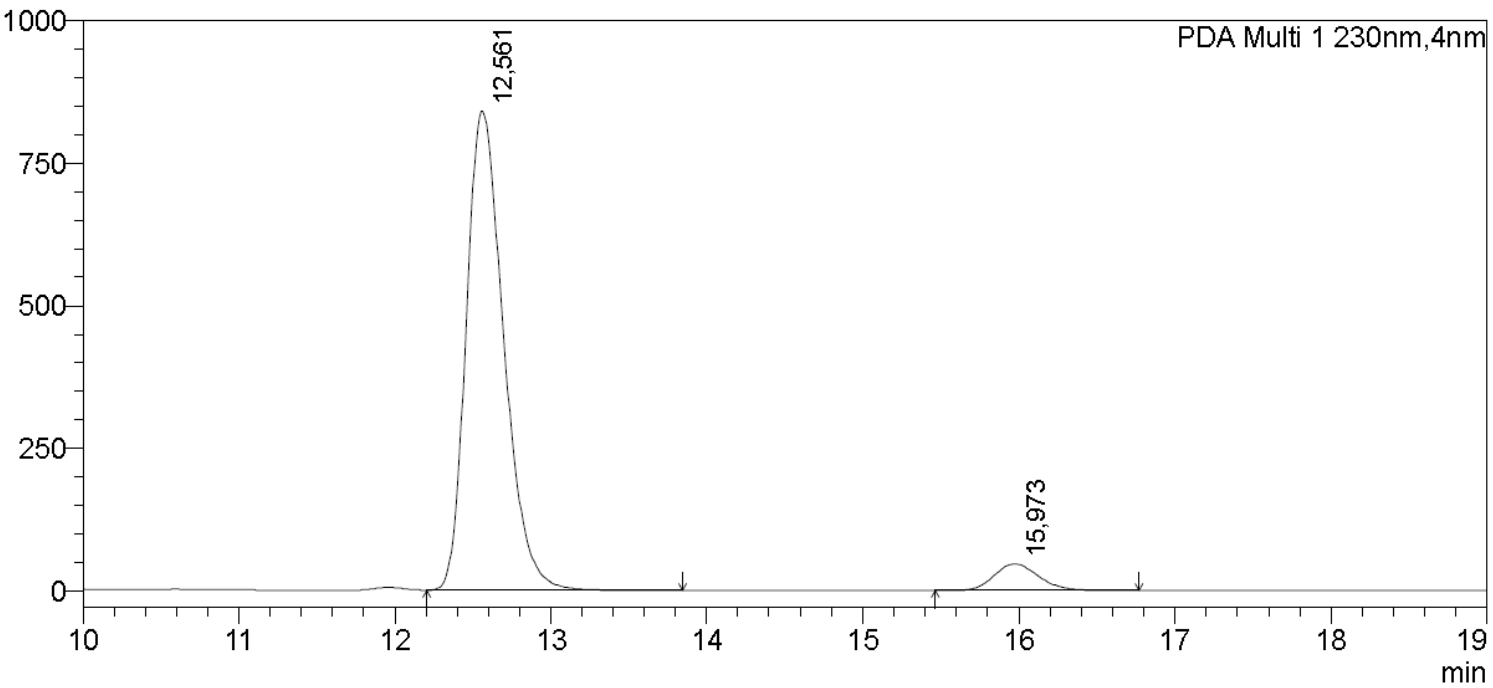

<Peak Table>

\begin{tabular}{|c|c|c|c|c|}
\hline \multirow{2}{*}{\multicolumn{2}{|c|}{$\begin{array}{l}\text { PDA Ch1 230nm } \\
\text { Peak\# Ret. Time }\end{array}$}} & & & \\
\hline & & Alea & Helgnt & Ared \\
\hline 1 & 12,561 & 14005281 & 840692 & 93,696 \\
\hline 2 & 15,973 & 942330 & 47067 & 6,304 \\
\hline Total & & 14947612 & 887759 & 100,000 \\
\hline
\end{tabular}



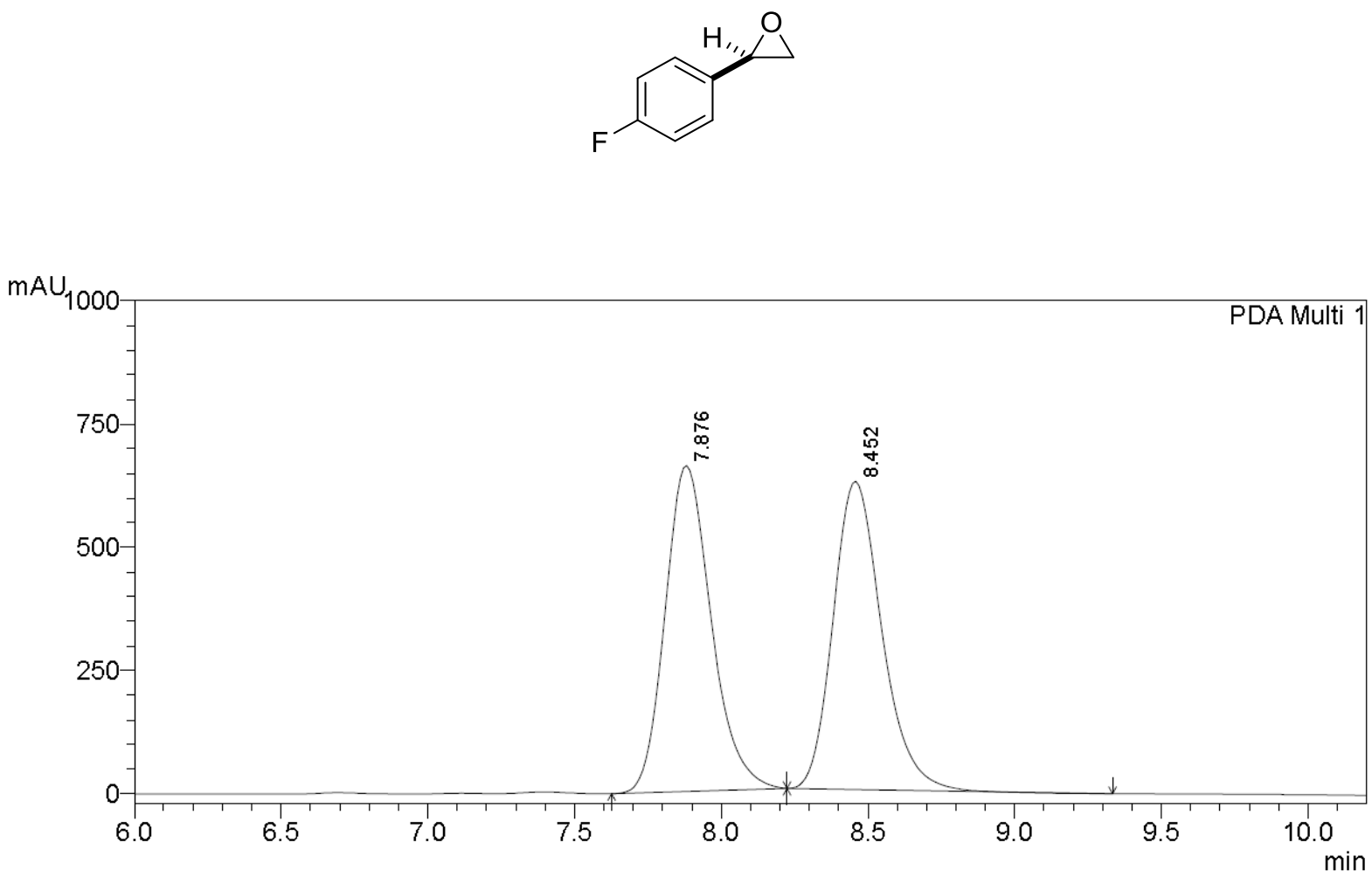

1 PDA Multi $1 / 210 \mathrm{~nm} 4 \mathrm{~nm}$

PeakTable

PDA Ch1 $210 \mathrm{~nm}$ 4nm
\begin{tabular}{|r|r|r|r|}
\hline Peak\# & Ret. Time & \multicolumn{1}{|c|}{ Area } & \multicolumn{1}{c|}{ Area $\%$} \\
\hline 1 & 7.876 & 7228015 & 50.096 \\
\hline 2 & 8.452 & 7200423 & 49.904 \\
\hline Total & & 14428438 & 100.000 \\
\hline
\end{tabular}

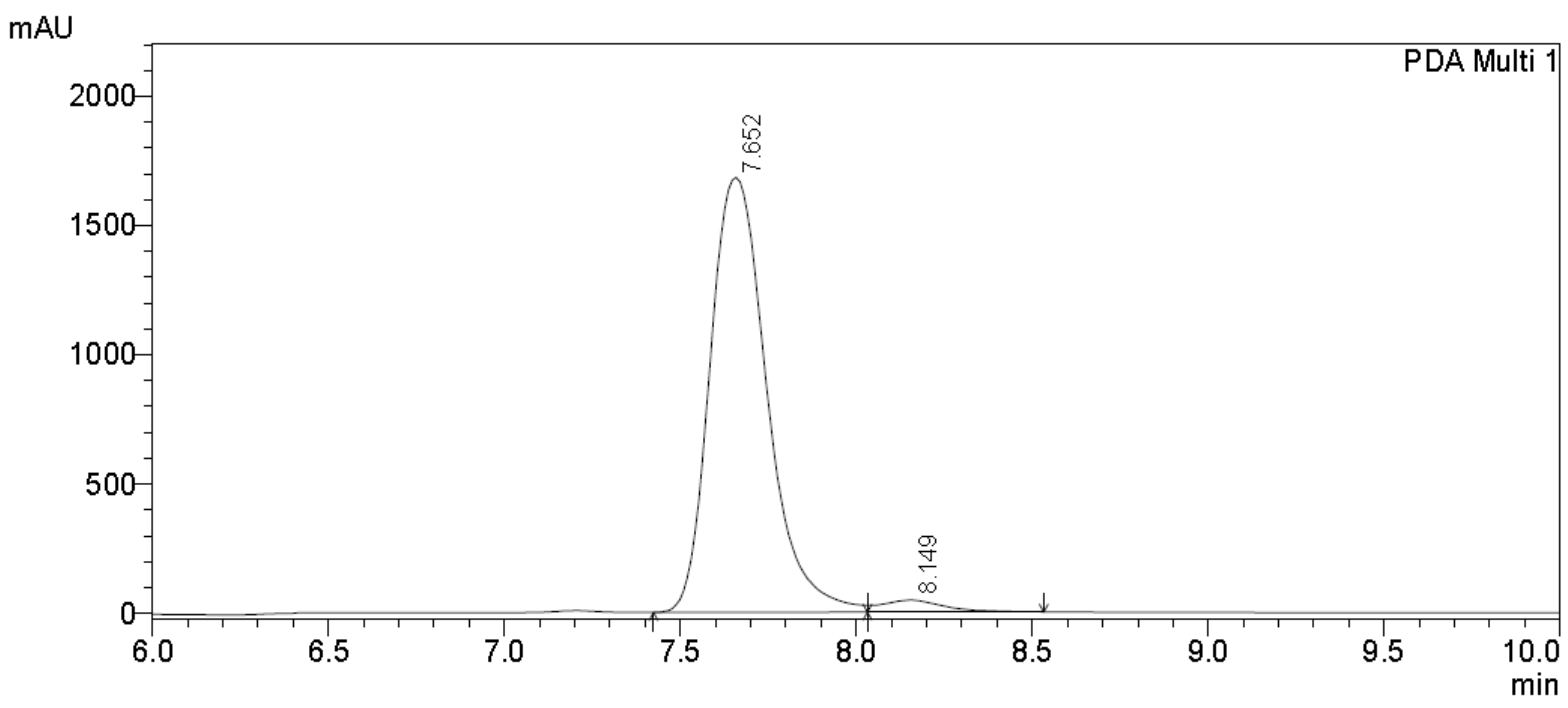

\begin{tabular}{|r|r|r|r|}
\hline \multicolumn{1}{|c|}{ Peak\# } & \multicolumn{1}{|c|}{ Ret. Time } & \multicolumn{1}{|c|}{ Area } & \multicolumn{1}{c|}{ Area \% } \\
\hline 1 & 7.652 & 18885136 & 97.119 \\
\hline 2 & 8.149 & 560198 & 2.881 \\
\hline Total & & 19445334 & 100.000 \\
\hline
\end{tabular}



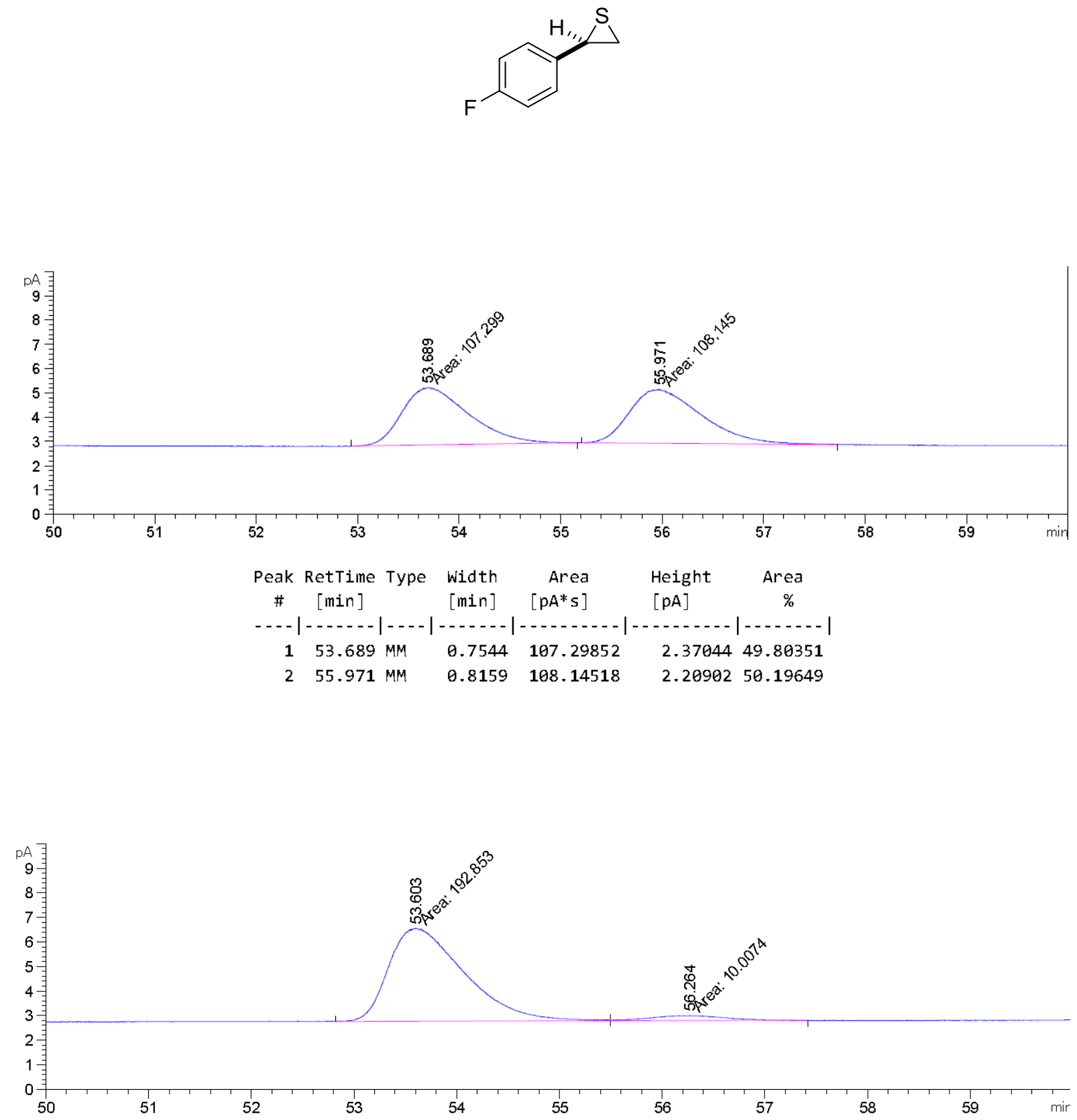

Peak RetTime Type width Area Height Area

\begin{tabular}{cccccc}
$\#$ & {$[\mathrm{~min}]$} & {$[\mathrm{min}]$} & {$\left[\mathrm{pA}{ }^{*} \mathrm{~s}\right]$} & {$[\mathrm{pA}]$} & $\%$ \\
\hline 1 & $53.603 \mathrm{MF}$ & 0.8493 & 192.85284 & 3.78453 & 95.06683
\end{tabular}

2 56.264 FM $\quad 0.8263 \quad 10.00744 \quad 2.01843 \mathrm{e}-1 \quad 4.93317$ 


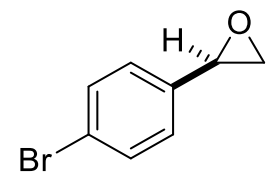

mAU

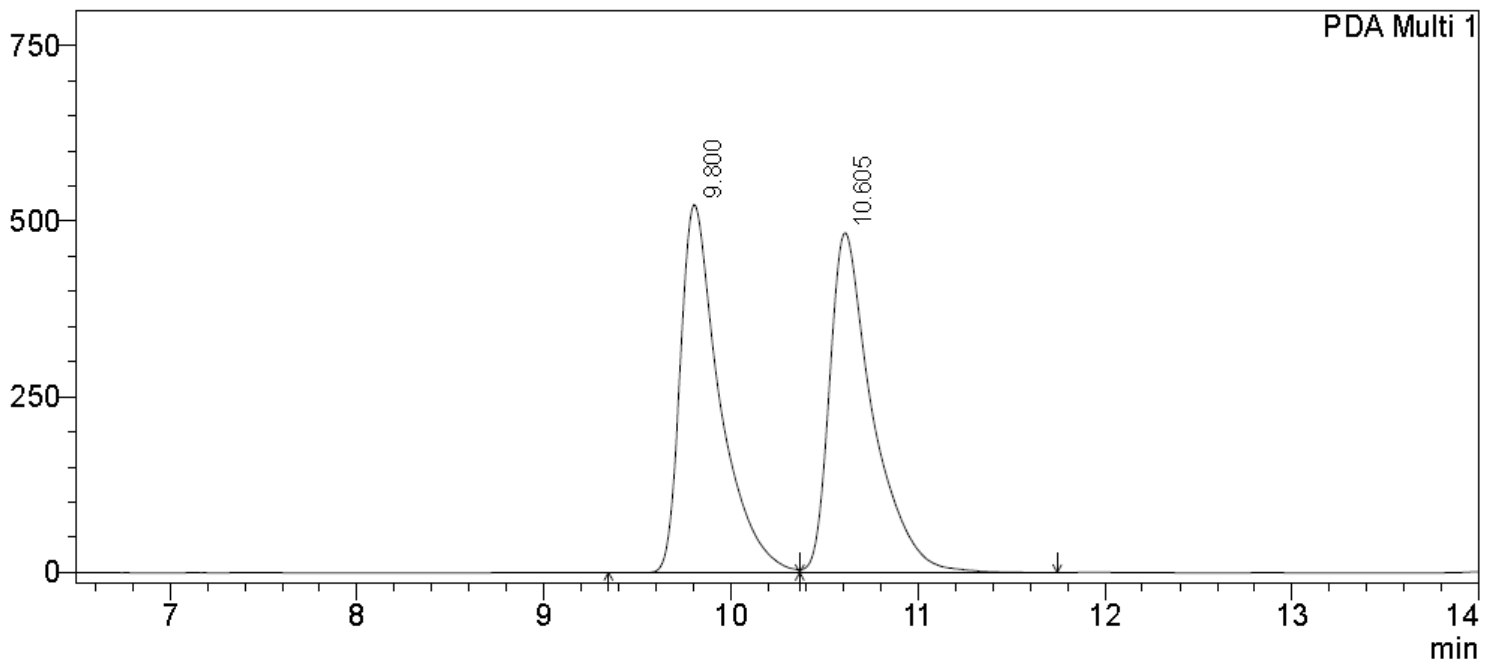

1 PDA Multi 1/220nm 4nm

PeakTable

PDA Ch1 220nm 4nm

\begin{tabular}{|r|r|r|r|}
\hline \multicolumn{1}{|c|}{ Peak\# } & Ret. Time & \multicolumn{1}{c|}{ Area } & \multicolumn{1}{c|}{ Area \% } \\
\hline 1 & 9.800 & 7700581 & 49.915 \\
\hline 2 & 10.605 & 7726829 & 50.085 \\
\hline Total & & 15427410 & 100.000 \\
\hline
\end{tabular}

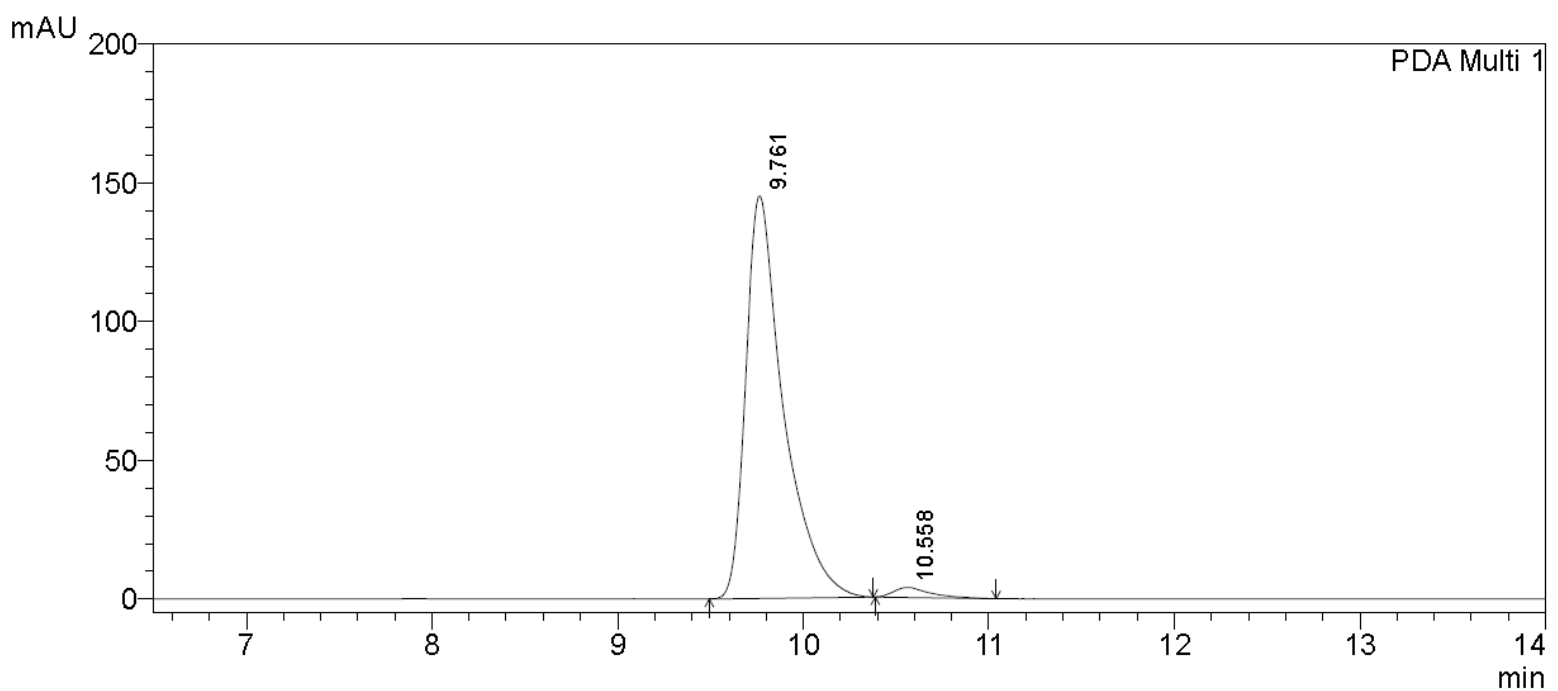

1 PDA Multi 1/220nm 4nm

PeakTable

PDA Ch1 220nm 4nm

\begin{tabular}{|r|r|r|r|}
\hline \multicolumn{1}{|c|}{ Peak\# } & Ret. Time & \multicolumn{1}{c|}{ Area } & \multicolumn{1}{|c|}{ Area \% } \\
\hline 1 & 9.761 & 2066618 & 97.716 \\
\hline 2 & 10.558 & 48313 & 2.284 \\
\hline Total & & 2114931 & 100.000 \\
\hline
\end{tabular}




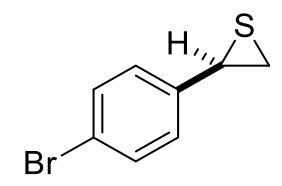

mAU

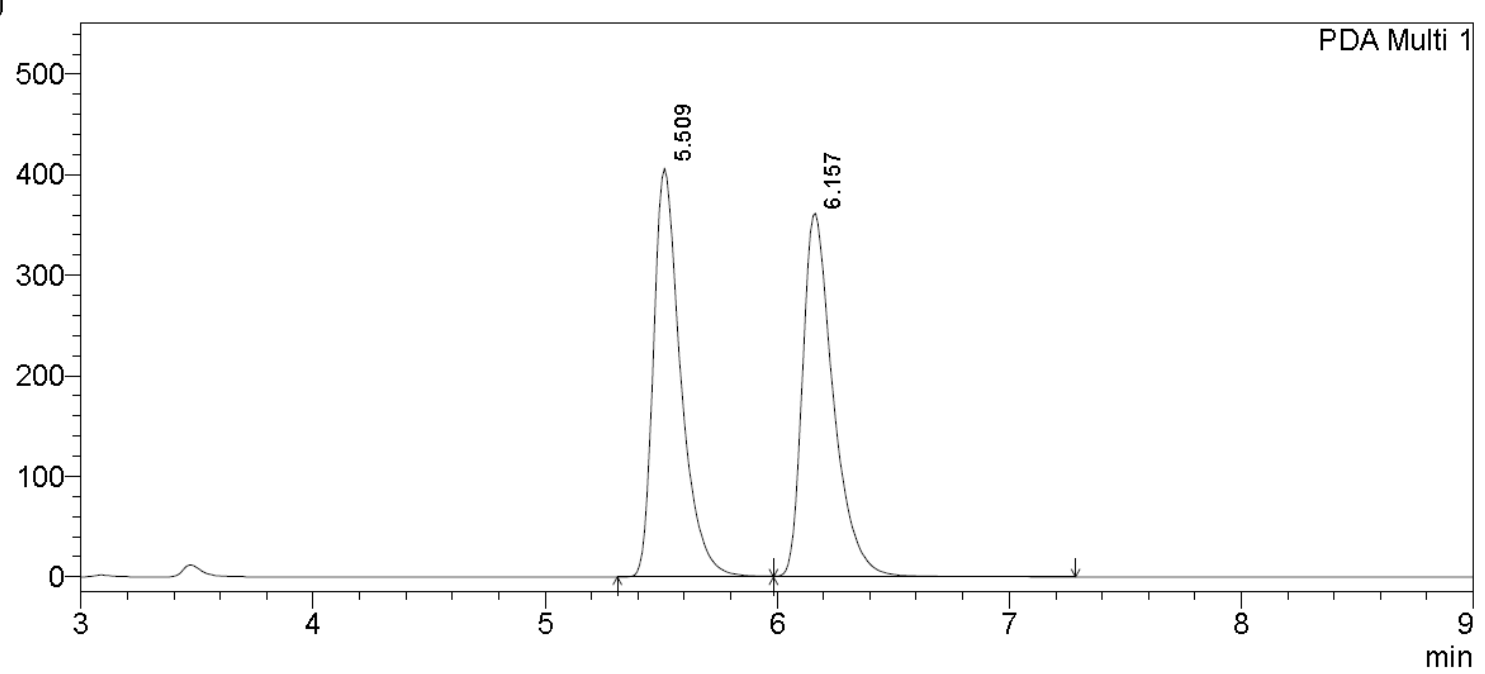

1 PDA Multi 1/235nm 4nm

PeakTable

PDA Ch1 $235 \mathrm{~nm}$ 4nm
\begin{tabular}{|r|r|r|r|}
\hline \multicolumn{1}{|c|}{ Peak\# } & Ret. Time & Area & \multicolumn{1}{c|}{ Area $\%$} \\
\hline 1 & 5.509 & 3321621 & 49.889 \\
\hline 2 & 6.157 & 3336461 & 50.111 \\
\hline Total & & 6658082 & 100.000 \\
\hline
\end{tabular}

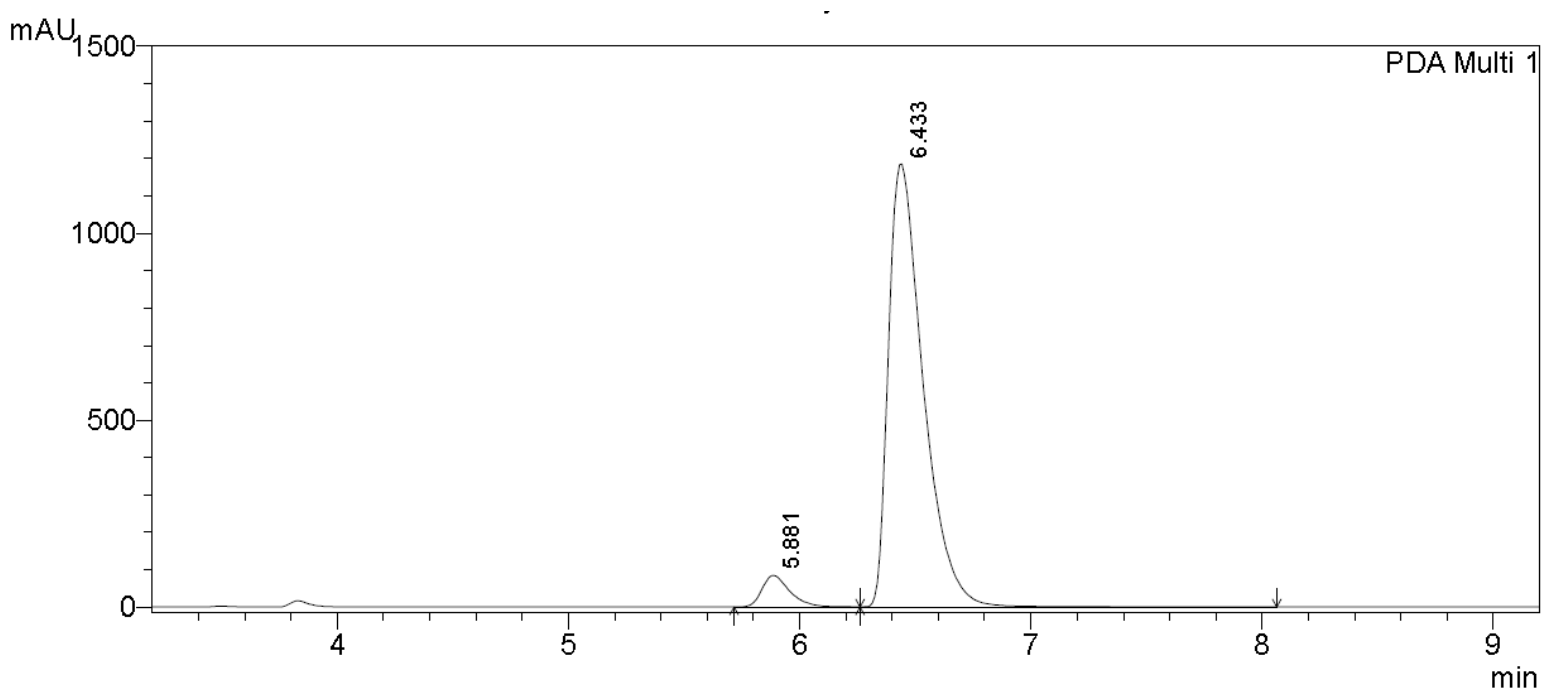

1 PDA Multi 1/235nm 4nm

PeakTable

PDACh1 235nm 4nm

\begin{tabular}{|r|r|r|r|}
\hline Peak\# & Ret. Time & Area & \multicolumn{1}{|c|}{ Area \% } \\
\hline 1 & 5.881 & 705323 & 5.397 \\
\hline 2 & 6.433 & 12364678 & 94.603 \\
\hline Total & & 13070001 & 100.000 \\
\hline
\end{tabular}




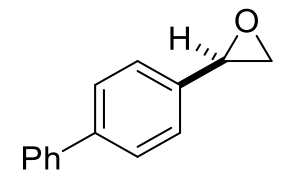

mAU

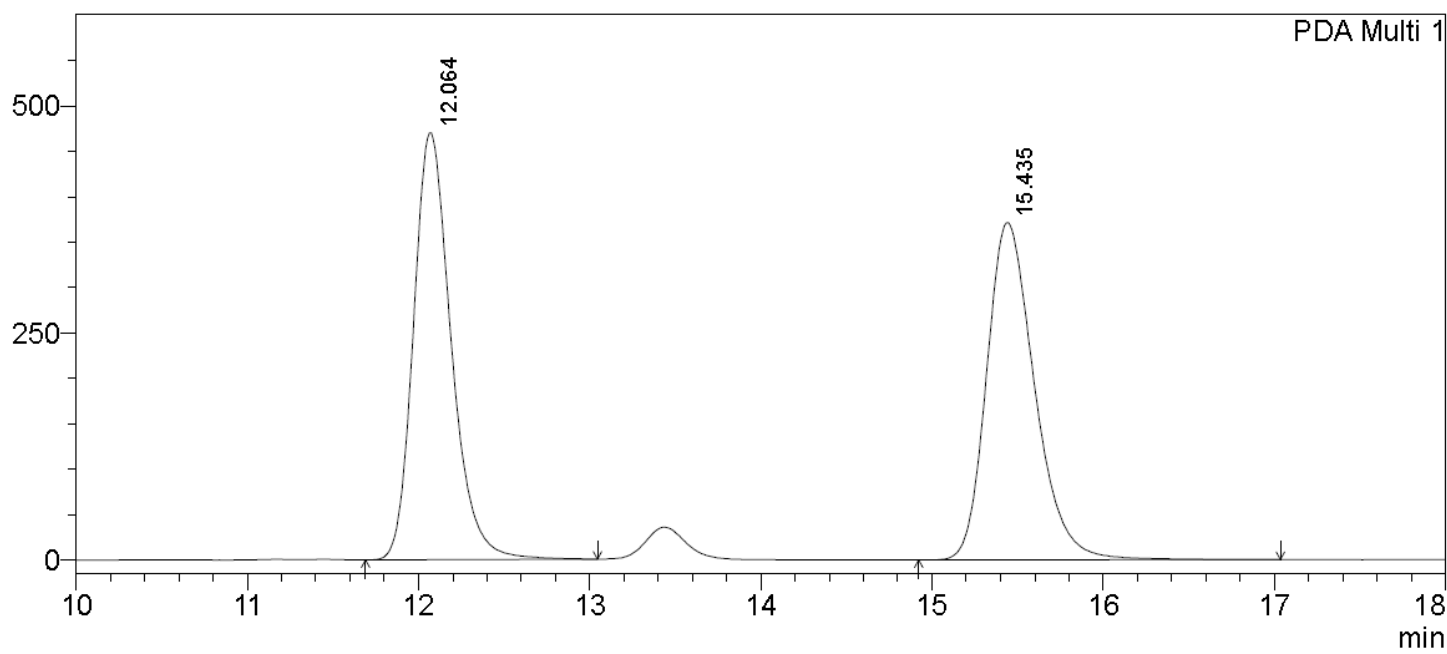

1 PDA Multi $1 / 254 \mathrm{~nm} \mathrm{4nm}$

PeakTable

PDA Ch1 $254 \mathrm{~nm} 4 \mathrm{~nm}$
\begin{tabular}{|r|r|r|r|}
\hline Peak\# & Ret. Time & \multicolumn{1}{|c|}{ Area } & \multicolumn{1}{|c|}{ Area $\%$} \\
\hline 1 & 12.064 & 7187832 & 49.885 \\
\hline 2 & 15.435 & 7221111 & 50.115 \\
\hline Total & & 14408943 & 100.000 \\
\hline
\end{tabular}

mAU

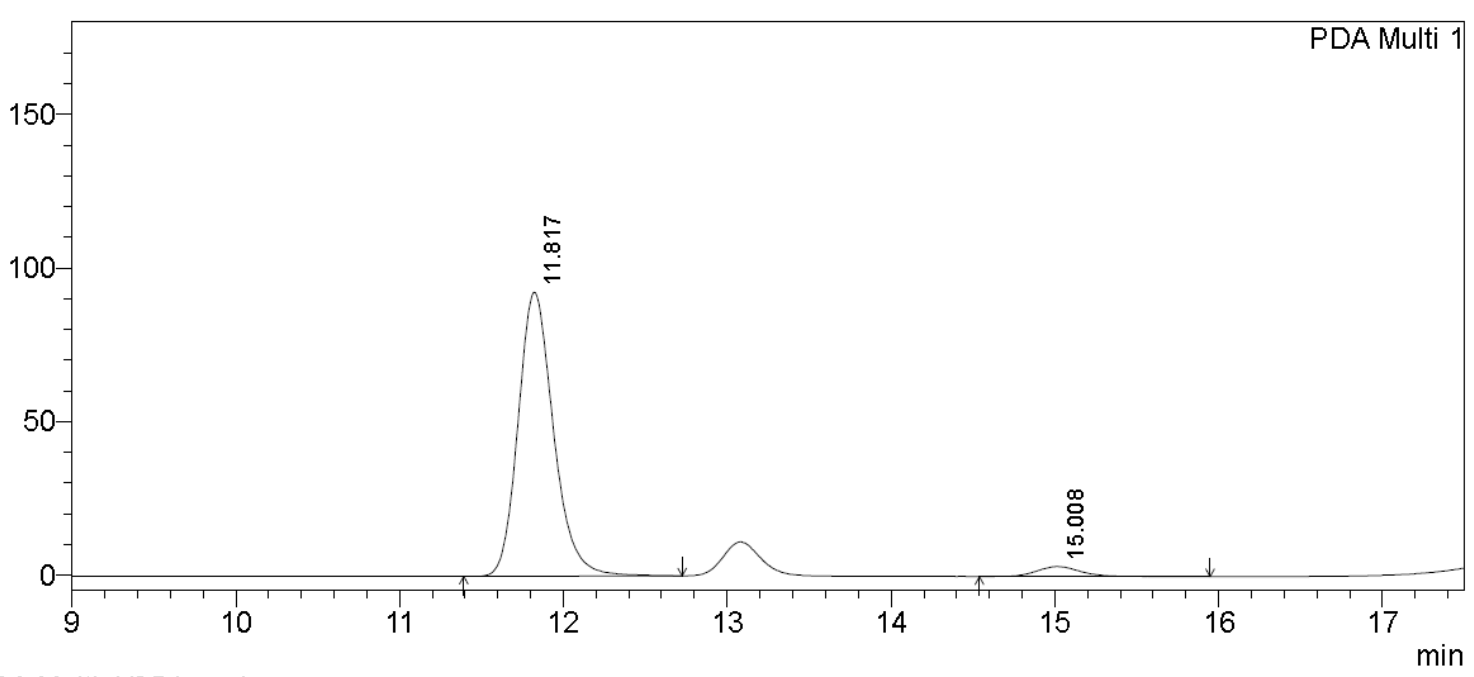

1 PDA Multi $1 / 254 \mathrm{~nm} 4 \mathrm{~nm}$

PeakTable

PDA Ch1 $254 \mathrm{~nm} 4 \mathrm{~nm}$
\begin{tabular}{|r|r|r|r|}
\hline Peak\# & Ret. Time & \multicolumn{1}{|c|}{ Area } & \multicolumn{1}{|c|}{ Area $\%$} \\
\hline 1 & 11.817 & 1389380 & 95.874 \\
\hline 2 & 15.008 & 59800 & 4.126 \\
\hline Total & & 1449180 & 100.000 \\
\hline
\end{tabular}


<smiles>c1ccc(-c2ccc([C@H]3CS3)cc2)cc1</smiles>

UAU

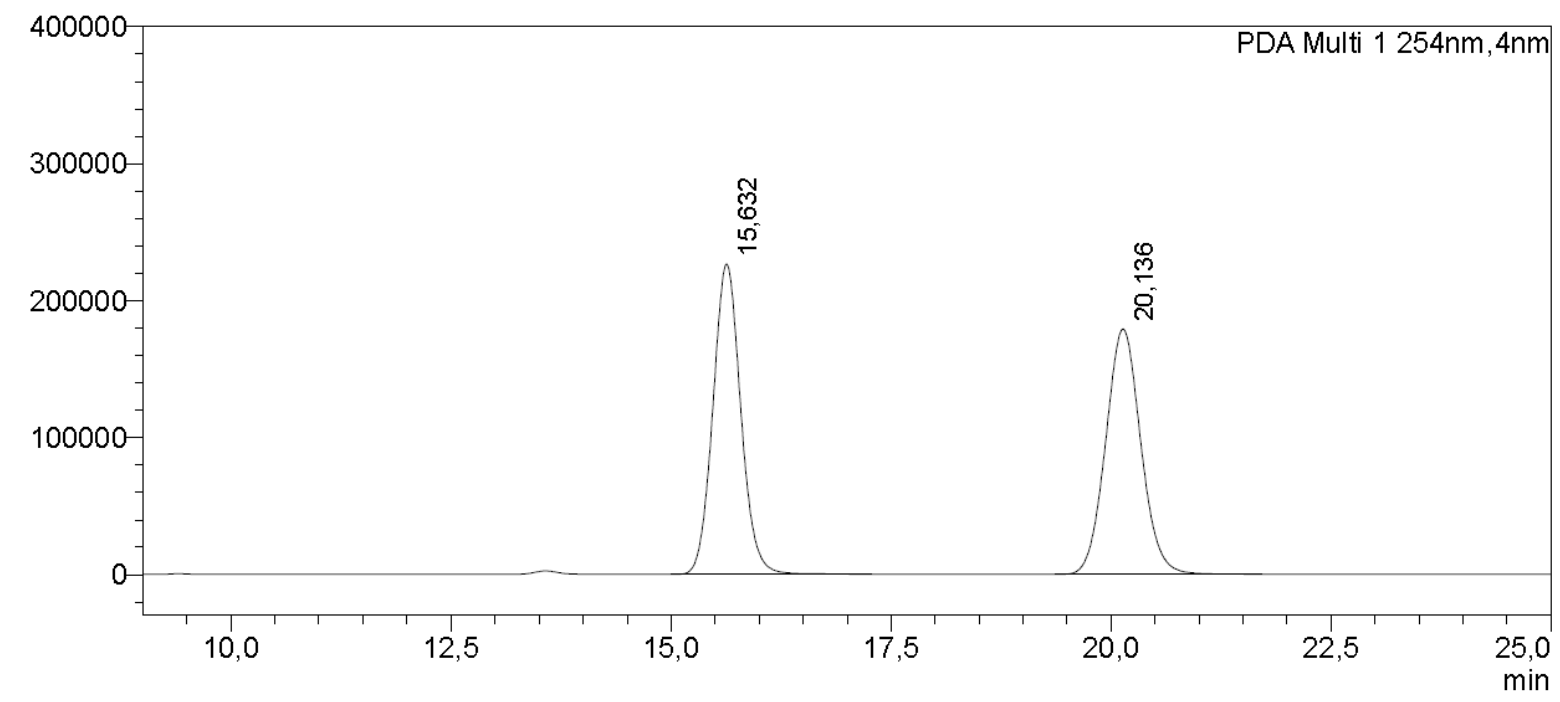

<Peak Table>

\begin{tabular}{|c|c|c|c|c|}
\hline \multicolumn{5}{|c|}{ PDA Ch1 254nm } \\
\hline Peak\# & Ret. Time & Height & Area & Area\% \\
\hline 1 & 15,632 & 226541 & 4997768 & 50,092 \\
\hline 2 & 20,136 & 179167 & 4979464 & 49,908 \\
\hline Total & & 405708 & 9977232 & 100,000 \\
\hline
\end{tabular}

UAU

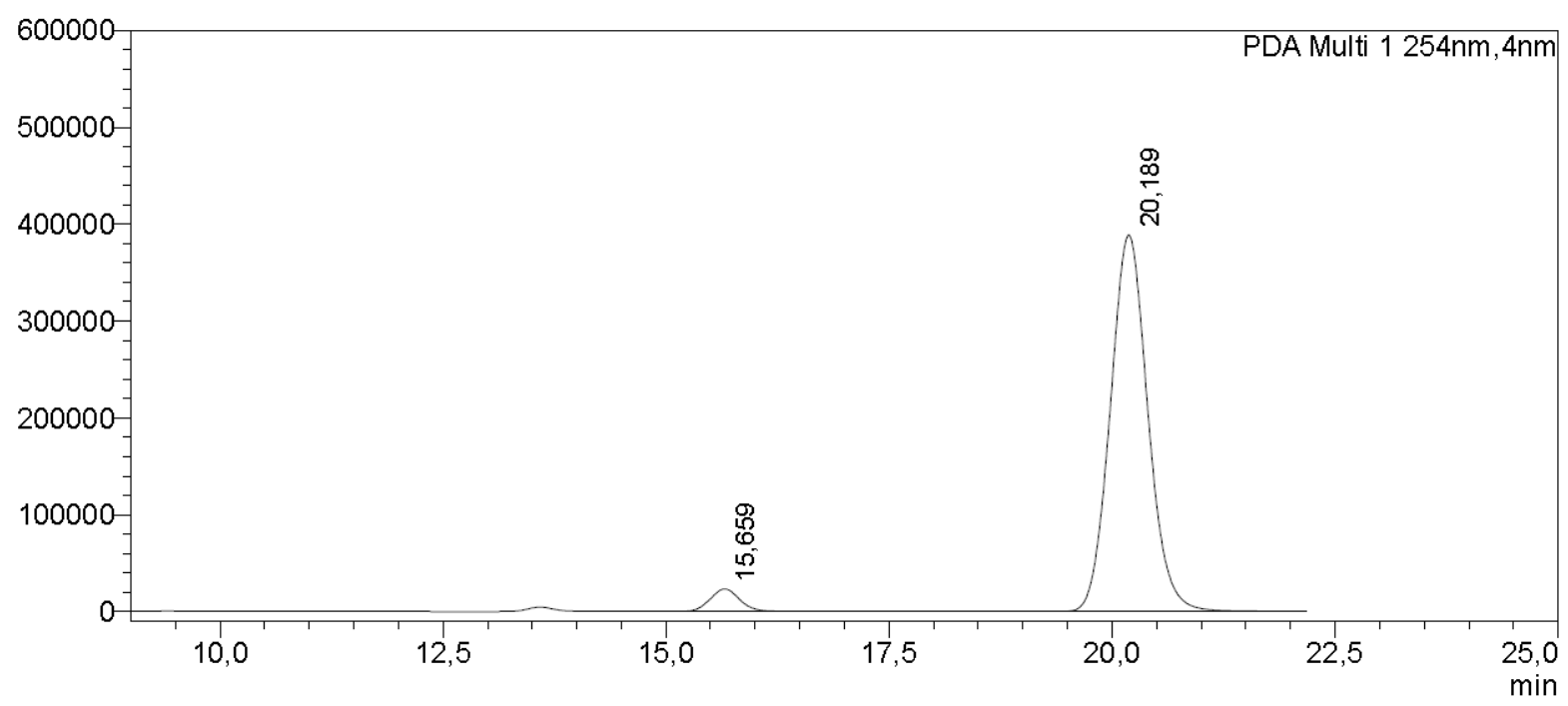

<Peak Table>

PDA Ch1 $254 \mathrm{~nm}$
\begin{tabular}{|r|r|r|r|r|}
\hline Peak\# & Ret. Time & Height & Area & Area $\%$ \\
\hline 1 & 15,659 & 23297 & 538063 & 4,513 \\
\hline 2 & 20,189 & 388780 & 11383141 & 95,487 \\
\hline Total & & 412077 & 11921204 & 100,000 \\
\hline
\end{tabular}




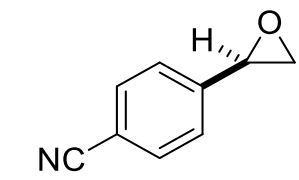

mAU

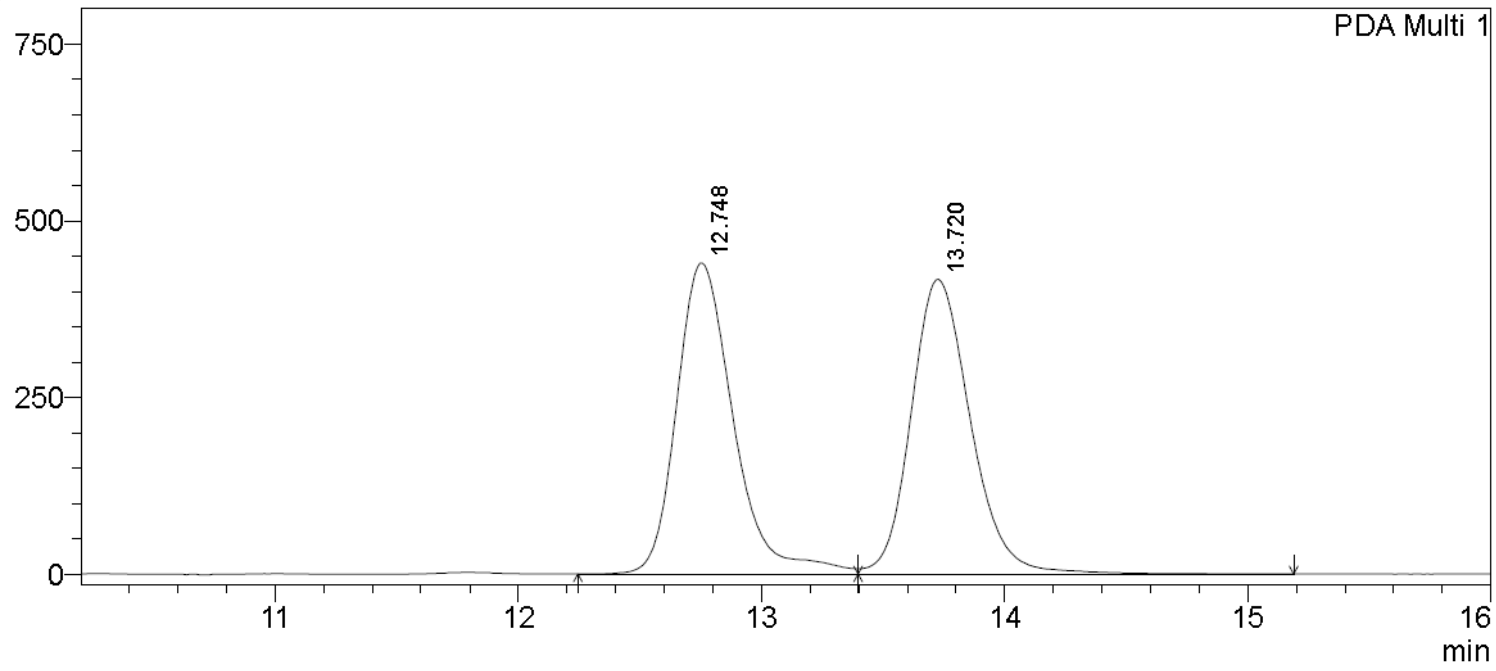

1 PDA Multi $1 / 205 \mathrm{~nm} 4 \mathrm{~nm}$

PeakTable

PDA Ch1 $205 \mathrm{~nm} 4 \mathrm{~nm}$
\begin{tabular}{|r|r|r|r|}
\hline Peak\# & Ret. Time & Area & Area $\%$ \\
\hline 1 & 12.748 & 7154279 & 50.272 \\
\hline 2 & 13.720 & 7076778 & 49.728 \\
\hline Total & & 14231057 & 100.000 \\
\hline
\end{tabular}

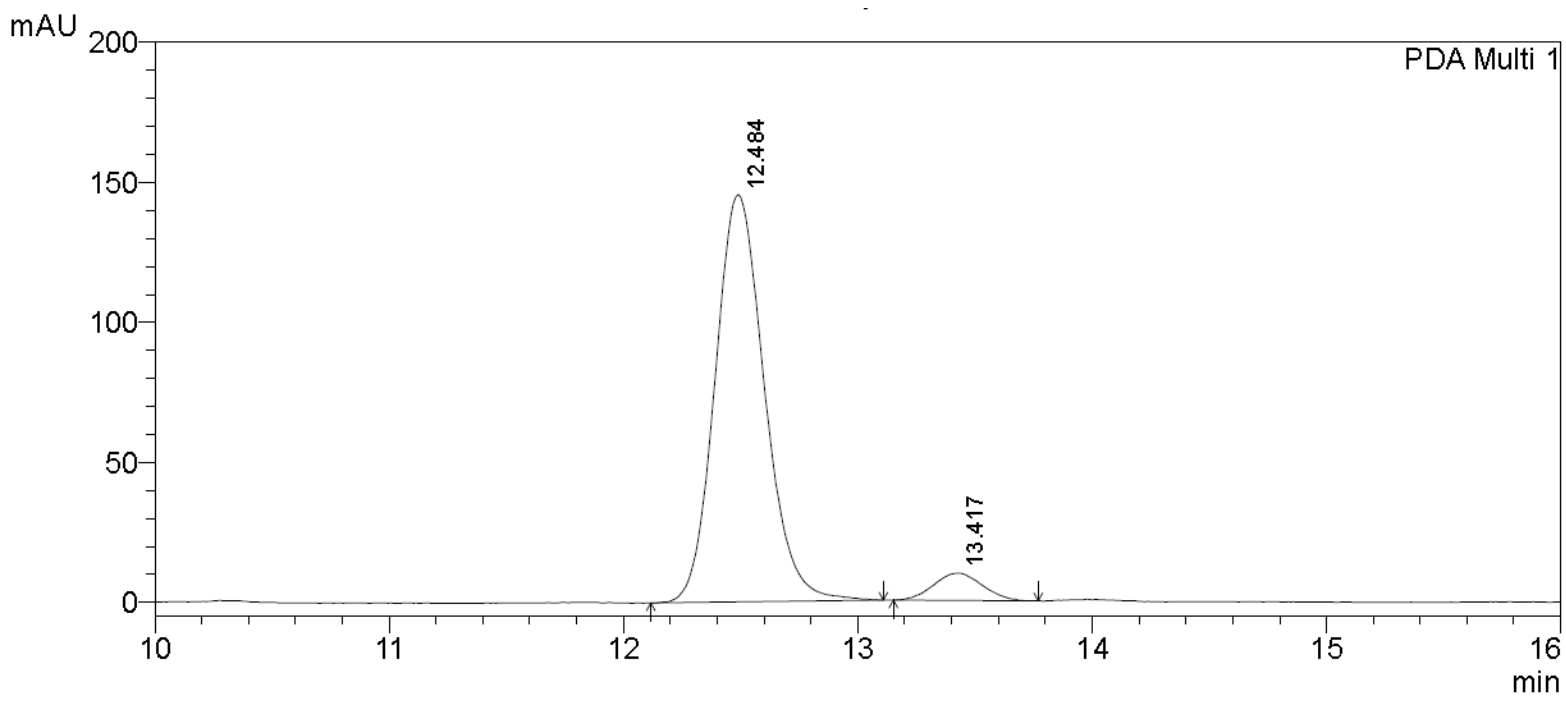

1 PDA Multi $1 / 205 \mathrm{~nm} 4 \mathrm{~nm}$

PeakTable

PDA Ch1 $205 \mathrm{~nm} 4 \mathrm{~nm}$
\begin{tabular}{|r|r|r|r|}
\hline Peak\# & Ret. Time & \multicolumn{1}{|c|}{ Area } & Area \% \\
\hline 1 & 12.484 & 2134715 & 93.802 \\
\hline 2 & 13.417 & 141051 & 6.198 \\
\hline Total & & 2275766 & 100.000 \\
\hline
\end{tabular}




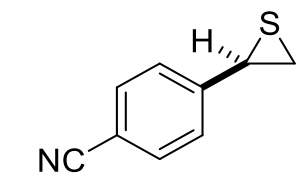

MAU

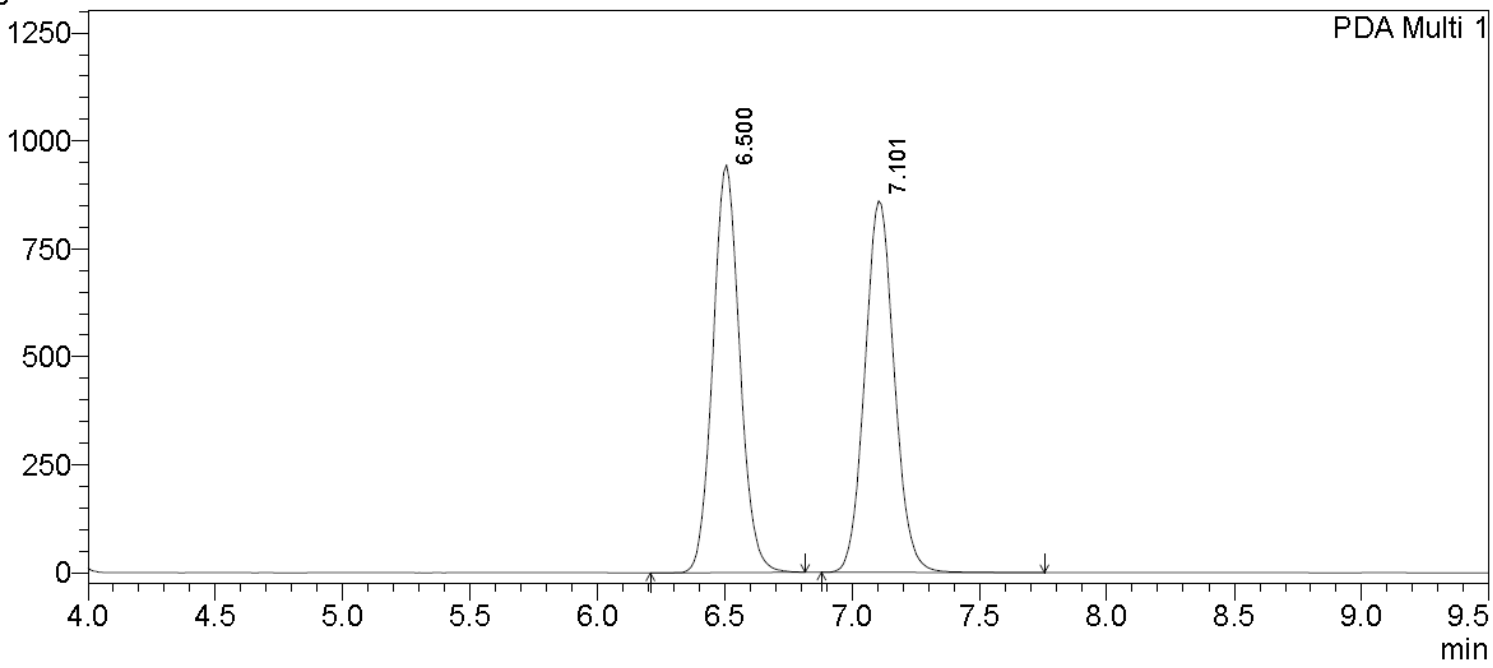

\begin{tabular}{|r|r|r|r|}
\hline Peak\# & Ret. Time & \multicolumn{1}{|c|}{ Area } & \multicolumn{1}{c|}{ Area \% } \\
\hline 1 & 6.500 & 6929140 & 49.996 \\
\hline 2 & 7.101 & 6930337 & 50.004 \\
\hline Total & & 13859476 & 100.000 \\
\hline
\end{tabular}

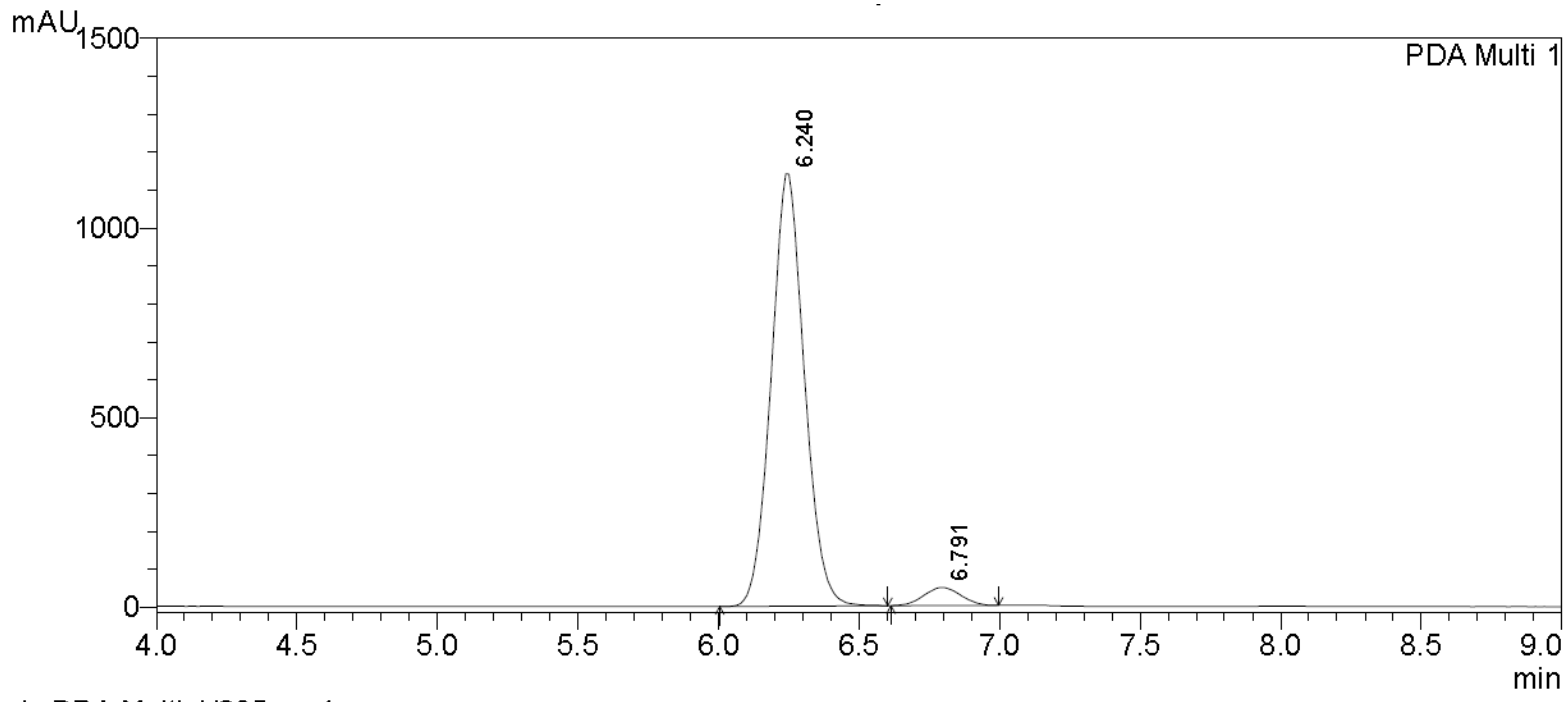

1 PDA Multi 1/205nm 4nm

PeakTable

PDA Ch1 205nm 4nm

\begin{tabular}{|r|r|r|r|}
\hline \multicolumn{1}{|c|}{ Peak\# } & Ret. Time & \multicolumn{1}{c|}{ Area } & \multicolumn{1}{c|}{ Area \% } \\
\hline 1 & 6.240 & 9368324 & 95.562 \\
\hline 2 & 6.791 & 435106 & 4.438 \\
\hline Total & & 9803429 & 100.000 \\
\hline
\end{tabular}




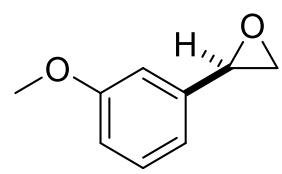

mAU

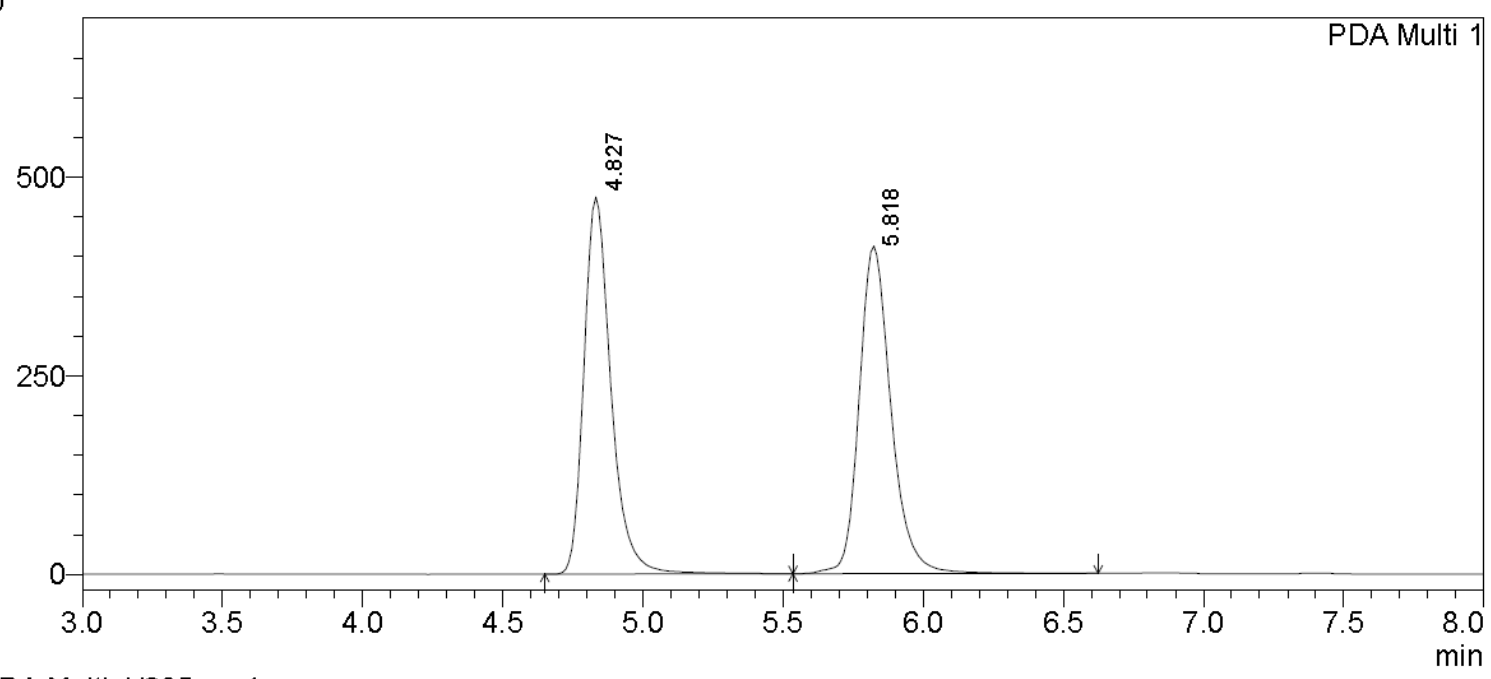

1 PDA Multi $1 / 205 \mathrm{~nm} 4 \mathrm{~nm}$

PeakTable

PDA Ch1 205nm 4nm

\begin{tabular}{|r|r|r|r|}
\hline \multicolumn{1}{|c|}{ Peak\# } & Ret. Time & \multicolumn{1}{|c|}{ Area } & \multicolumn{1}{|c|}{ Area \% } \\
\hline 1 & 4.827 & 3194595 & 49.458 \\
\hline 2 & 5.818 & 3264672 & 50.542 \\
\hline Total & & 6459267 & 100.000 \\
\hline
\end{tabular}

mAU

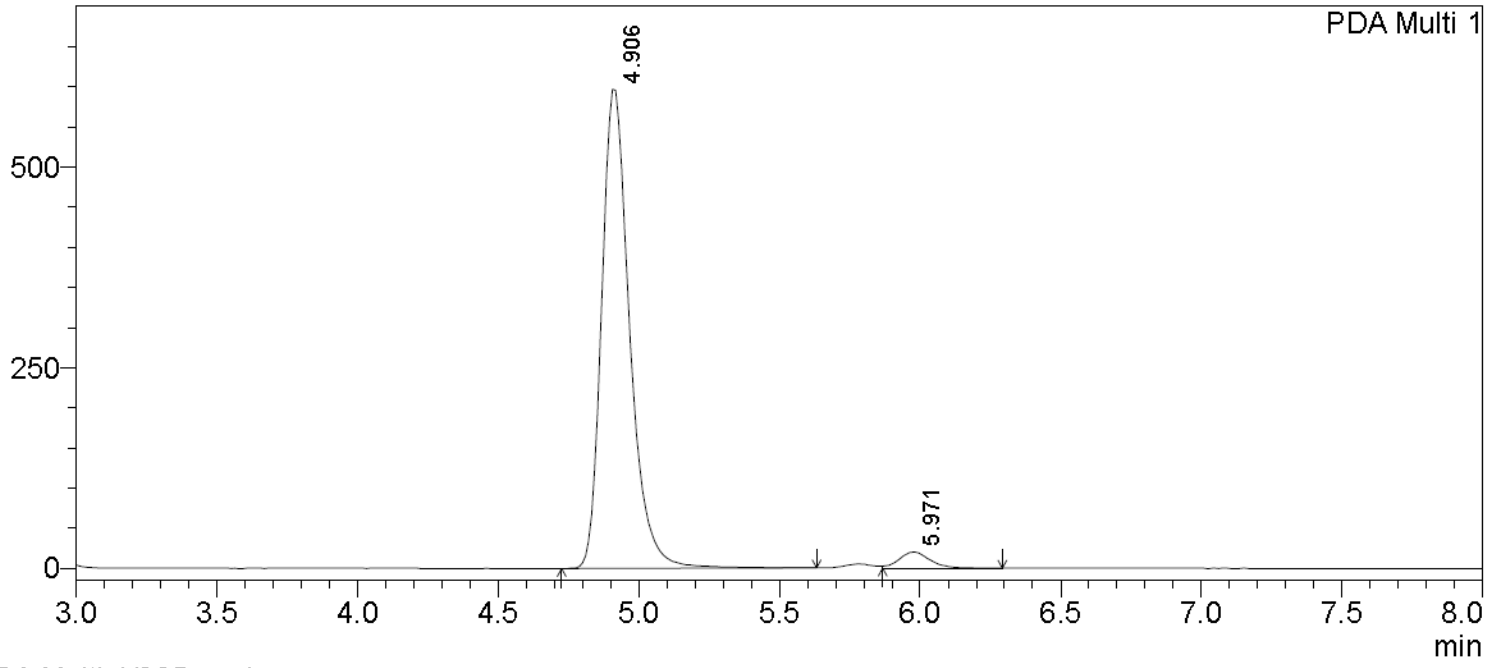

1 PDA Multi $1 / 205 \mathrm{~nm} 4 \mathrm{~nm}$

PeakTable

PDA Ch1 205nm 4nm

\begin{tabular}{|r|r|r|r|}
\hline \multicolumn{1}{|c|}{ Peak\# } & Ret. Time & \multicolumn{1}{c|}{ Area } & \multicolumn{1}{c|}{ Area \% } \\
\hline 1 & 4.906 & 4141957 & 96.442 \\
\hline 2 & 5.971 & 152803 & 3.558 \\
\hline Total & & 4294760 & 100.000 \\
\hline
\end{tabular}



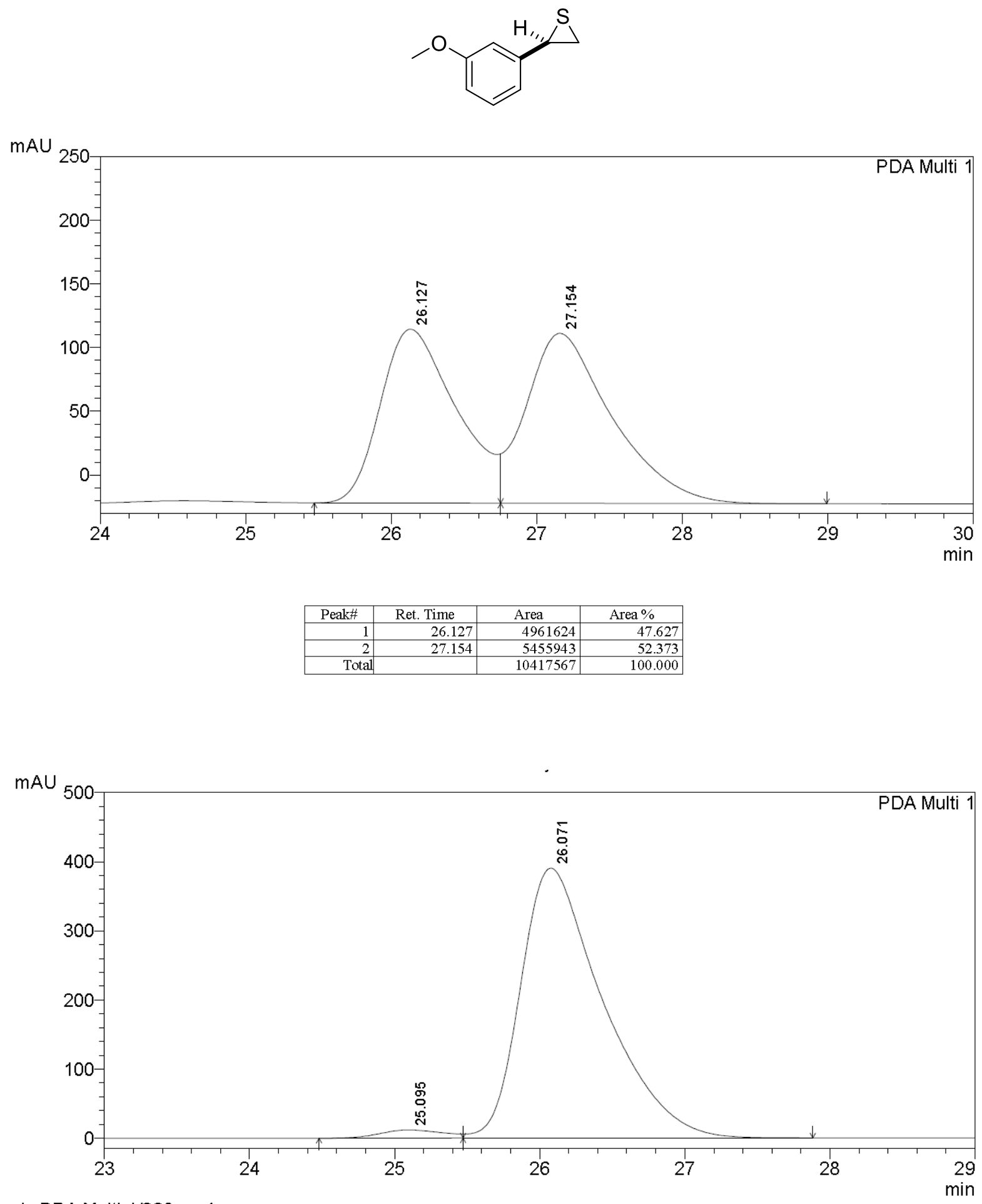

1 PDA Multi 1/220nm 4nm

PeakTable

PDA Ch1 $220 \mathrm{~nm} 4 \mathrm{~nm}$
\begin{tabular}{|r|r|r|r|}
\hline Peak\# & Ret. Time & Area & Area $\%$ \\
\hline 1 & 25.095 & 358746 & 2.279 \\
\hline 2 & 26.071 & 15381059 & 97.721 \\
\hline Total & & 15739804 & 100.000 \\
\hline
\end{tabular}


<smiles>Fc1cccc([C@H]2CO2)c1</smiles>
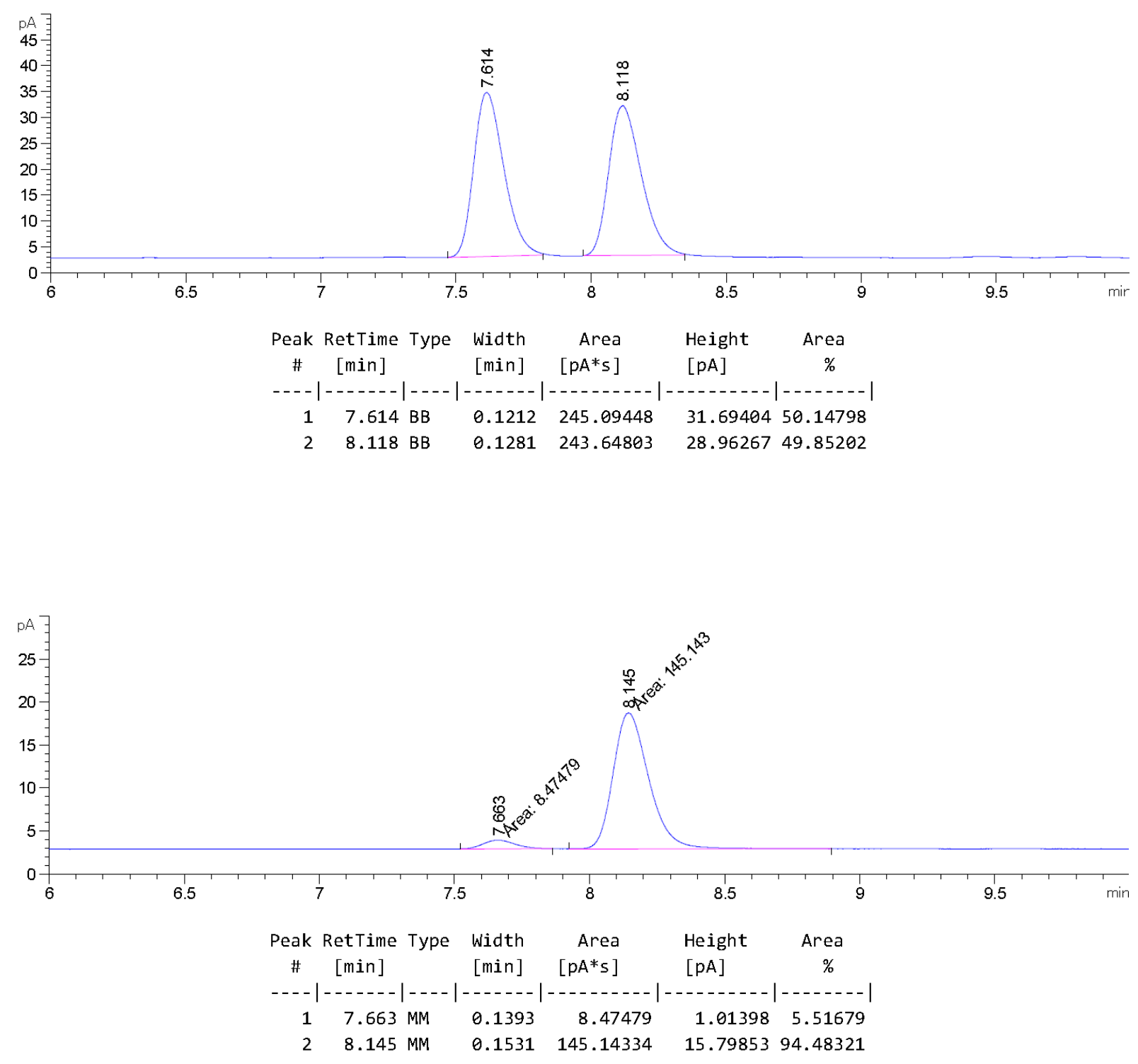
<smiles>Fc1cccc([C@H]2CS2)c1</smiles>
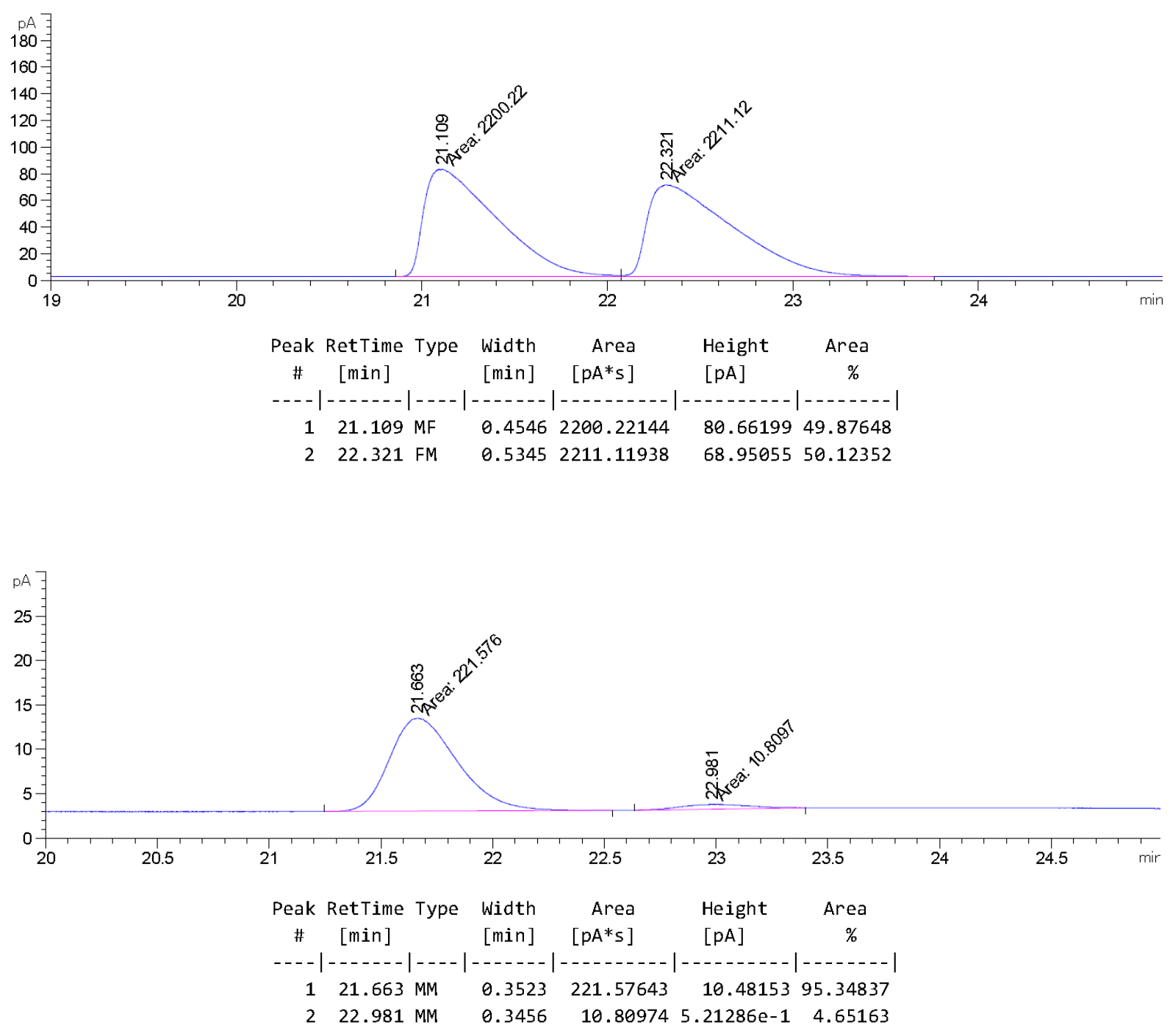

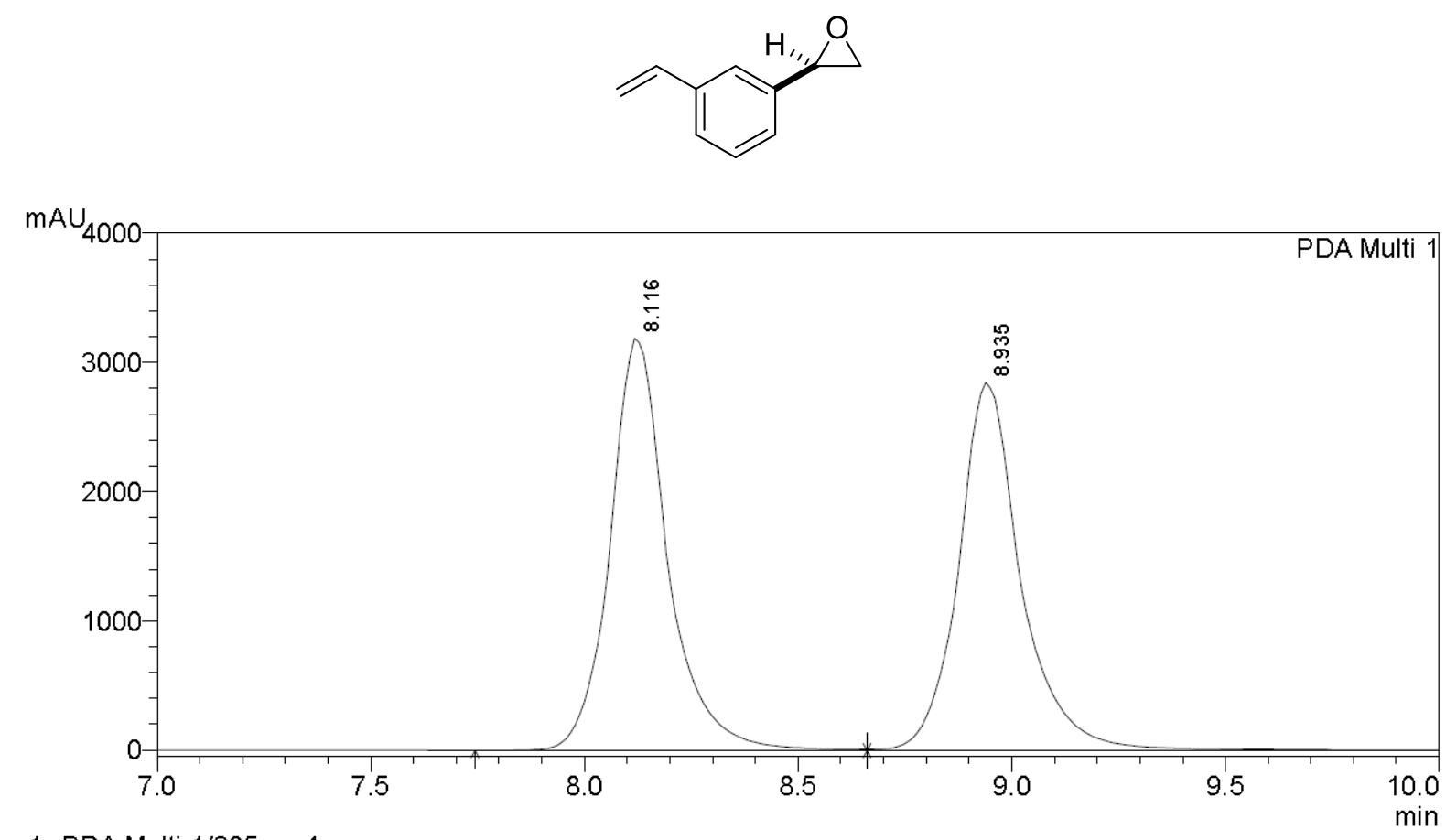

1 PDA Multi 1/205nm 4nm

PeakTable

PDA Ch1 $205 \mathrm{~nm} 4 \mathrm{~nm}$
\begin{tabular}{|r|r|l|r|}
\hline Peak\# & \multicolumn{1}{|c|}{ Ret. Time } & Area & Area $\%$ \\
\hline 1 & 8.116 & 29820501 & 50.661 \\
\hline 2 & 8.935 & 29042234 & 49.339 \\
\hline Total & & 58862735 & 100.000 \\
\hline
\end{tabular}

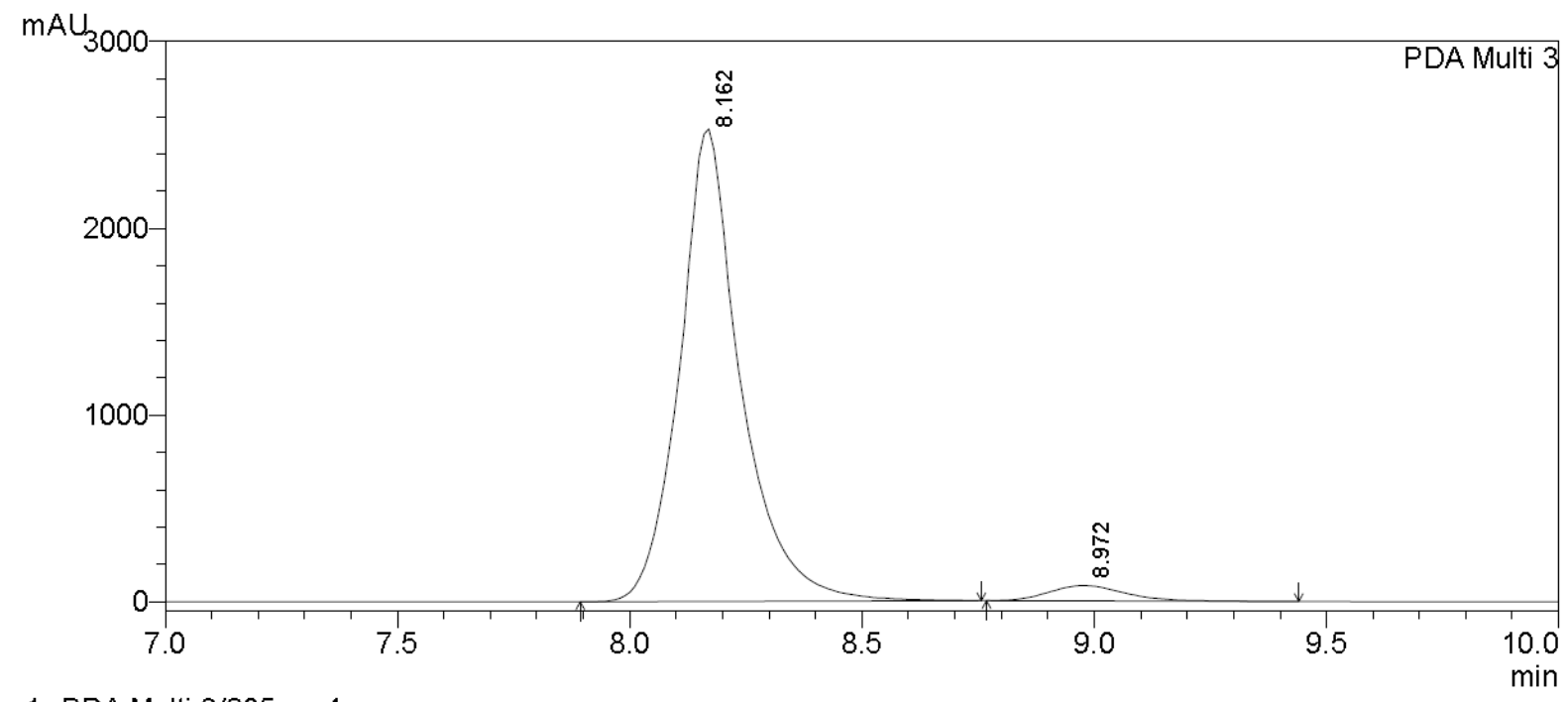

1 PDA Multi 3/205nm 4nm

PeakTable

PDA Ch3 205nm 4nm

\begin{tabular}{|r|r|r|r|}
\hline Peak\# & \multicolumn{1}{|c|}{ Ret. Time } & \multicolumn{1}{|c|}{ Area } & \multicolumn{1}{|c|}{ Area \% } \\
\hline 1 & 8.162 & 23129374 & 96.109 \\
\hline 2 & 8.972 & 936300 & 3.891 \\
\hline Total & & 24065673 & 100.000 \\
\hline
\end{tabular}



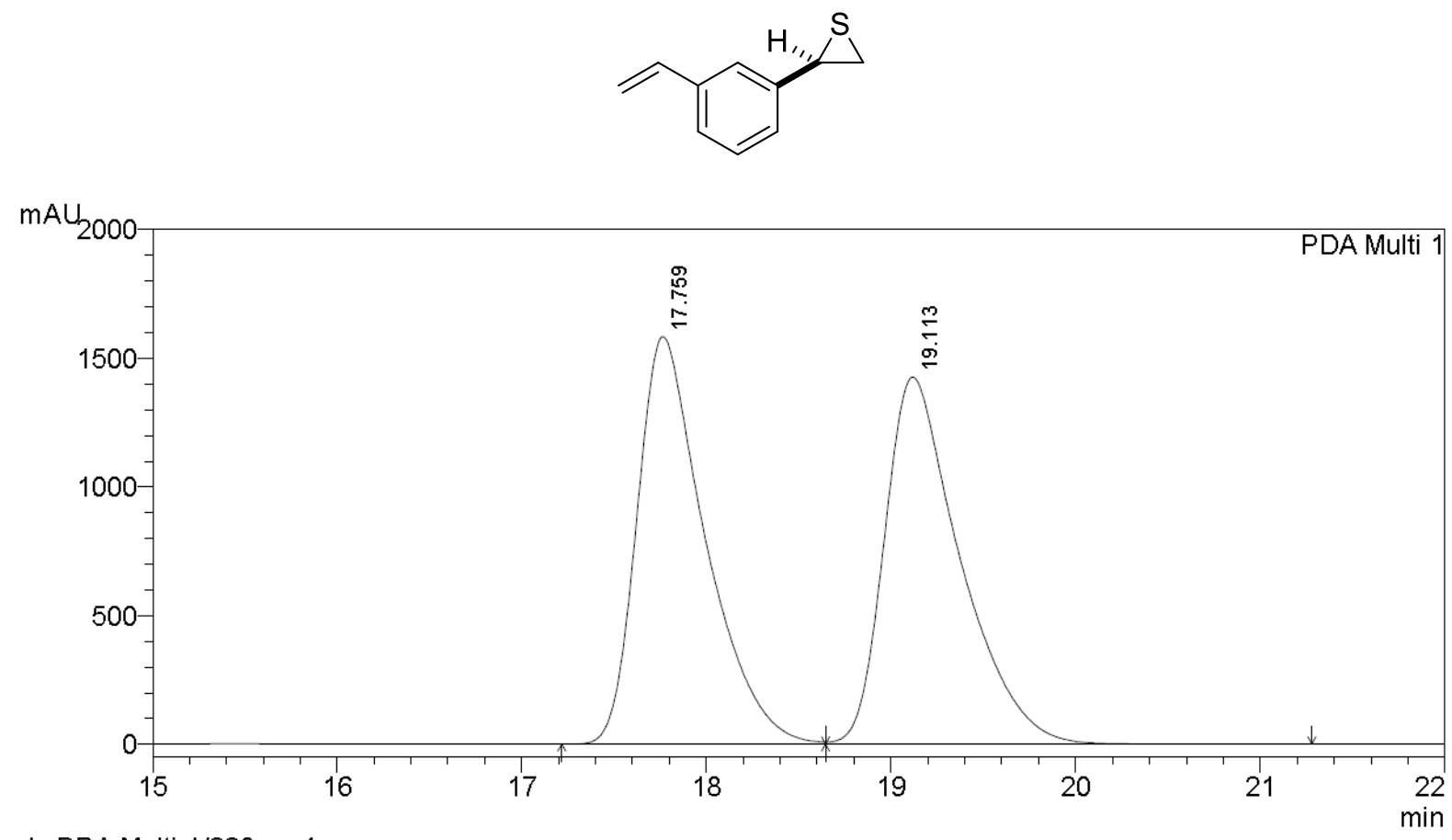

1 PDA Multi 1/220nm 4nm

PeakTable

PDA Ch1 220nm 4nm

\begin{tabular}{|r|r|r|r|}
\hline \multicolumn{1}{|c|}{ Peak\# } & Ret. Time & \multicolumn{1}{|c|}{ Area } & \multicolumn{1}{|c|}{ Area \% } \\
\hline 1 & 17.759 & 40702876 & 50.061 \\
\hline 2 & 19.113 & 40602922 & 49.939 \\
\hline Total & & 81305798 & 100.000 \\
\hline
\end{tabular}

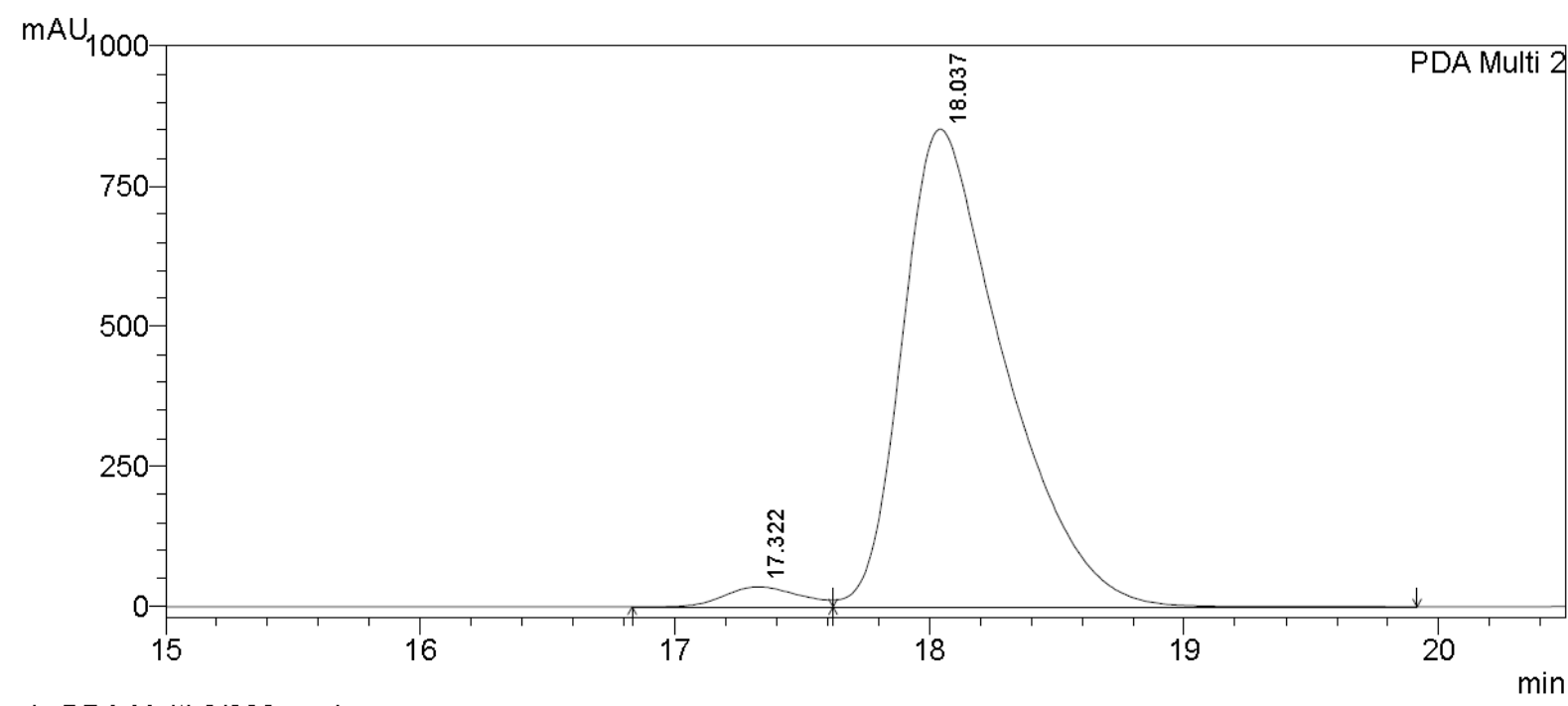

1 PDA Multi $2 / 220 \mathrm{~nm} 4 \mathrm{~nm}$

PeakTable

PDA Ch2 220nm 4nm

\begin{tabular}{|r|r|r|r|}
\hline Peak\# & Ret. Time & \multicolumn{1}{|c|}{ Area } & \multicolumn{1}{|c|}{ Area \% } \\
\hline 1 & 17.322 & 735734 & 3.002 \\
\hline 2 & 18.037 & 23768841 & 96.998 \\
\hline Total & & 24504575 & 100.000 \\
\hline
\end{tabular}



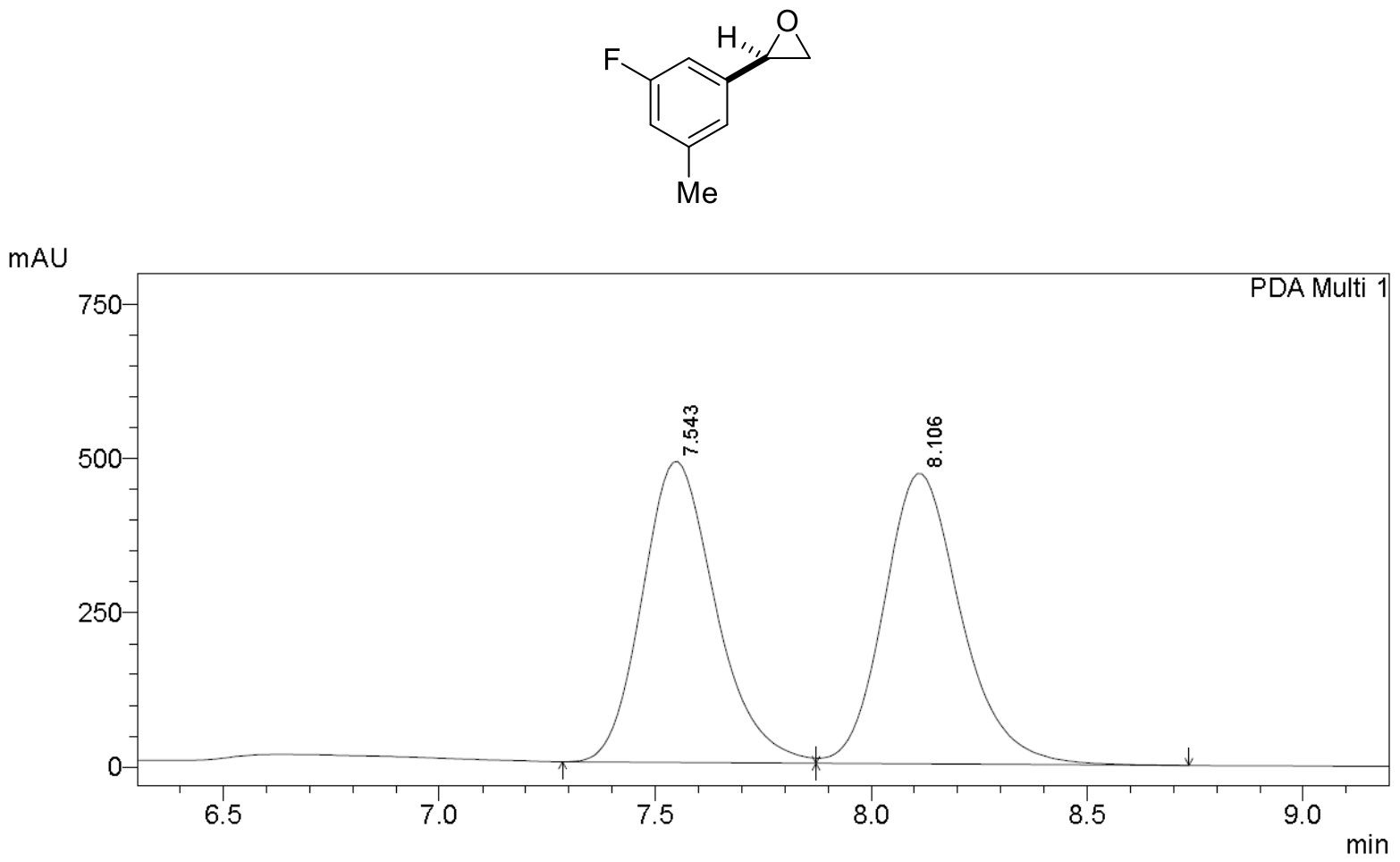

\begin{tabular}{|r|r|r|r|}
\hline Peak\# & Ret. Time & \multicolumn{1}{|c|}{ Area } & \multicolumn{1}{c|}{ Area \% } \\
\hline 1 & 7.543 & 5780441 & 49.635 \\
\hline 2 & 8.106 & 5865464 & 50.365 \\
\hline Total & & 11645905 & 100.000 \\
\hline
\end{tabular}

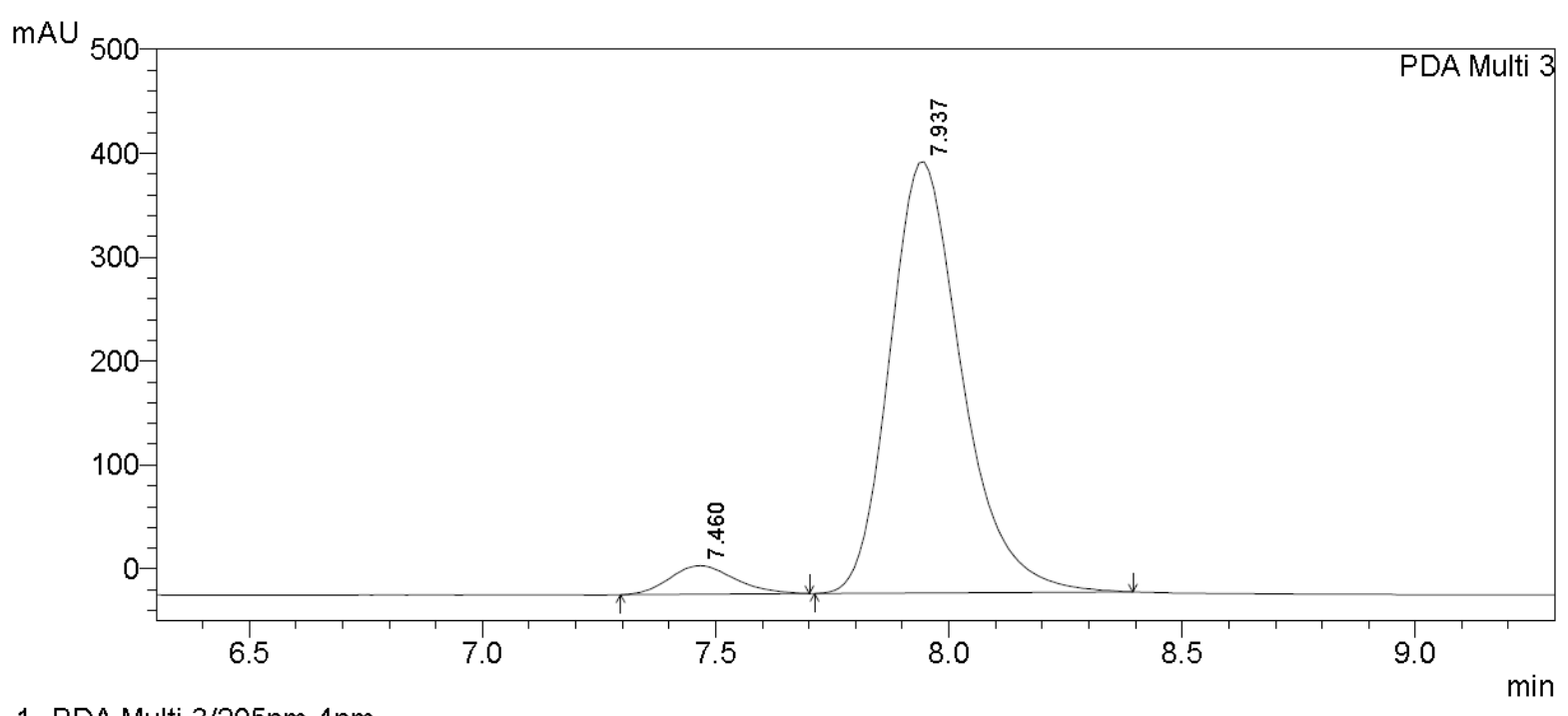

1 PDA Multi 3/205nm 4nm

PeakTable

PDA Ch3 $205 \mathrm{~nm} 4 \mathrm{~nm}$
\begin{tabular}{|r|r|r|r|}
\hline \multicolumn{1}{|c|}{ Peak\# } & Ret. Time & Area & Area $\%$ \\
\hline 1 & 7.460 & 264344 & 5.584 \\
\hline 2 & 7.937 & 4469526 & 94.416 \\
\hline Total & & 4733870 & 100.000 \\
\hline
\end{tabular}




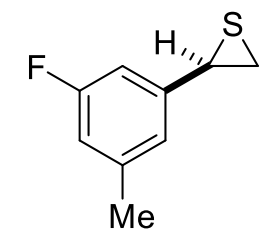

mAU

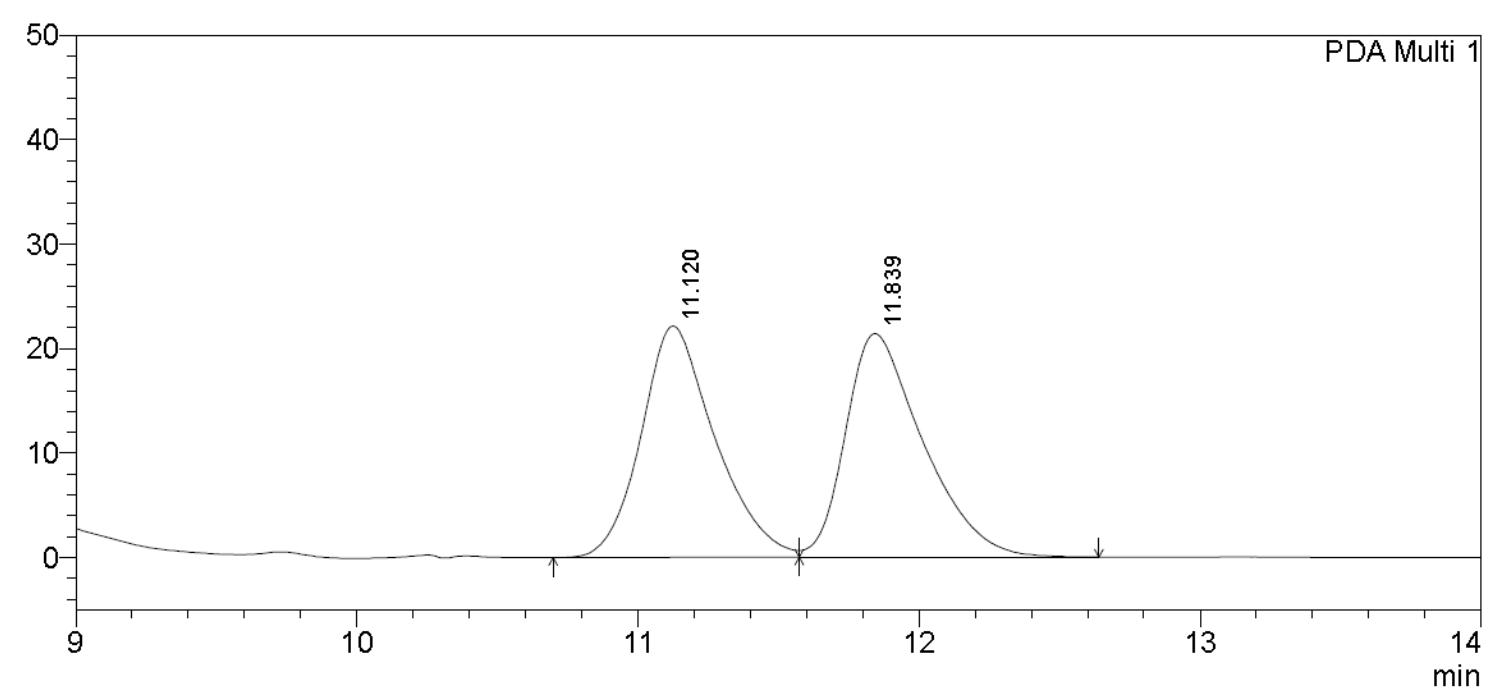

\begin{tabular}{|r|r|r|r|}
\hline Peak\# & Ret. Time & \multicolumn{1}{|c|}{ Area } & \multicolumn{1}{|c|}{ Area \% } \\
\hline 1 & 11.120 & 404811 & 49.743 \\
\hline 2 & 11.839 & 409001 & 50.257 \\
\hline Total & & 813812 & 100.000 \\
\hline
\end{tabular}

mAU

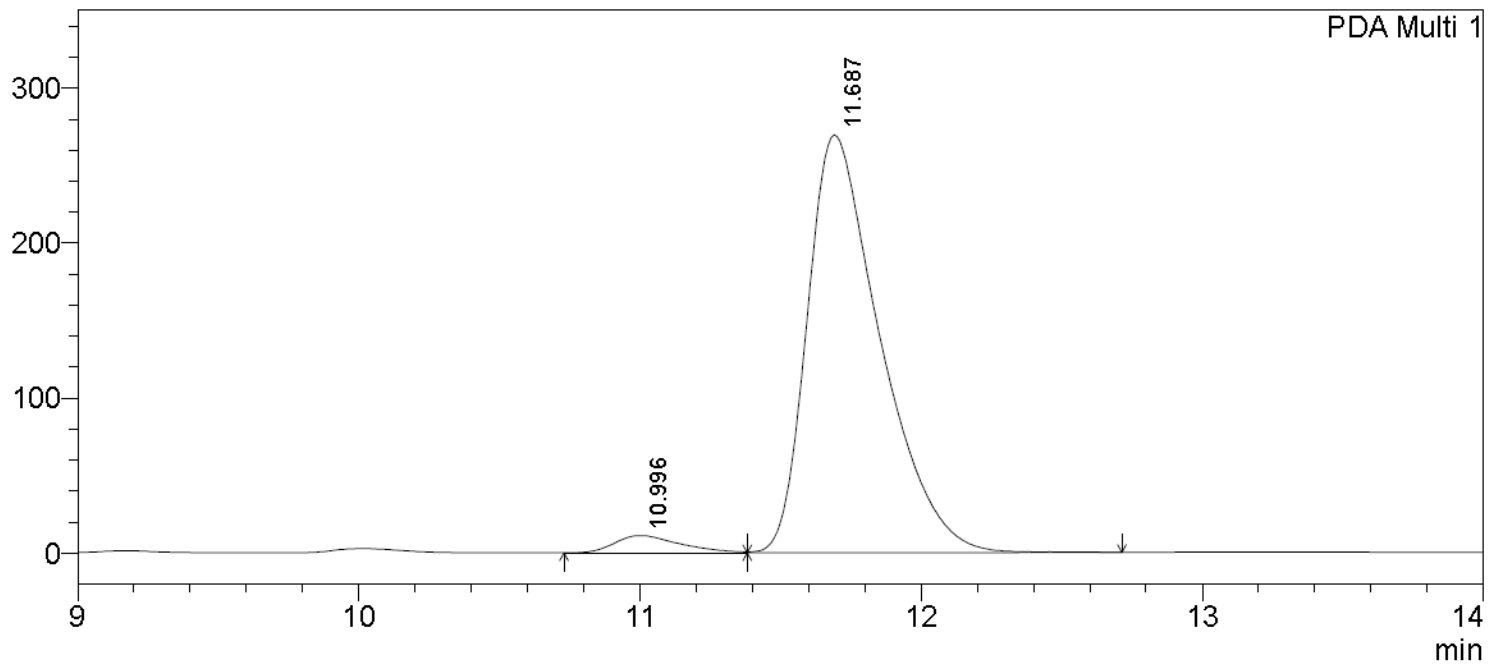

1 PDA Multi 1/220nm 4nm

PeakTable

PDA Ch1 220nm 4nm

\begin{tabular}{|r|r|r|r|}
\hline Peak\# & Ret. Time & \multicolumn{1}{|c|}{ Area } & \multicolumn{1}{|c|}{ Area \% } \\
\hline 1 & 10.996 & 179655 & 3.570 \\
\hline 2 & 11.687 & 4852468 & 96.430 \\
\hline Total & & 5032124 & 100.000 \\
\hline
\end{tabular}



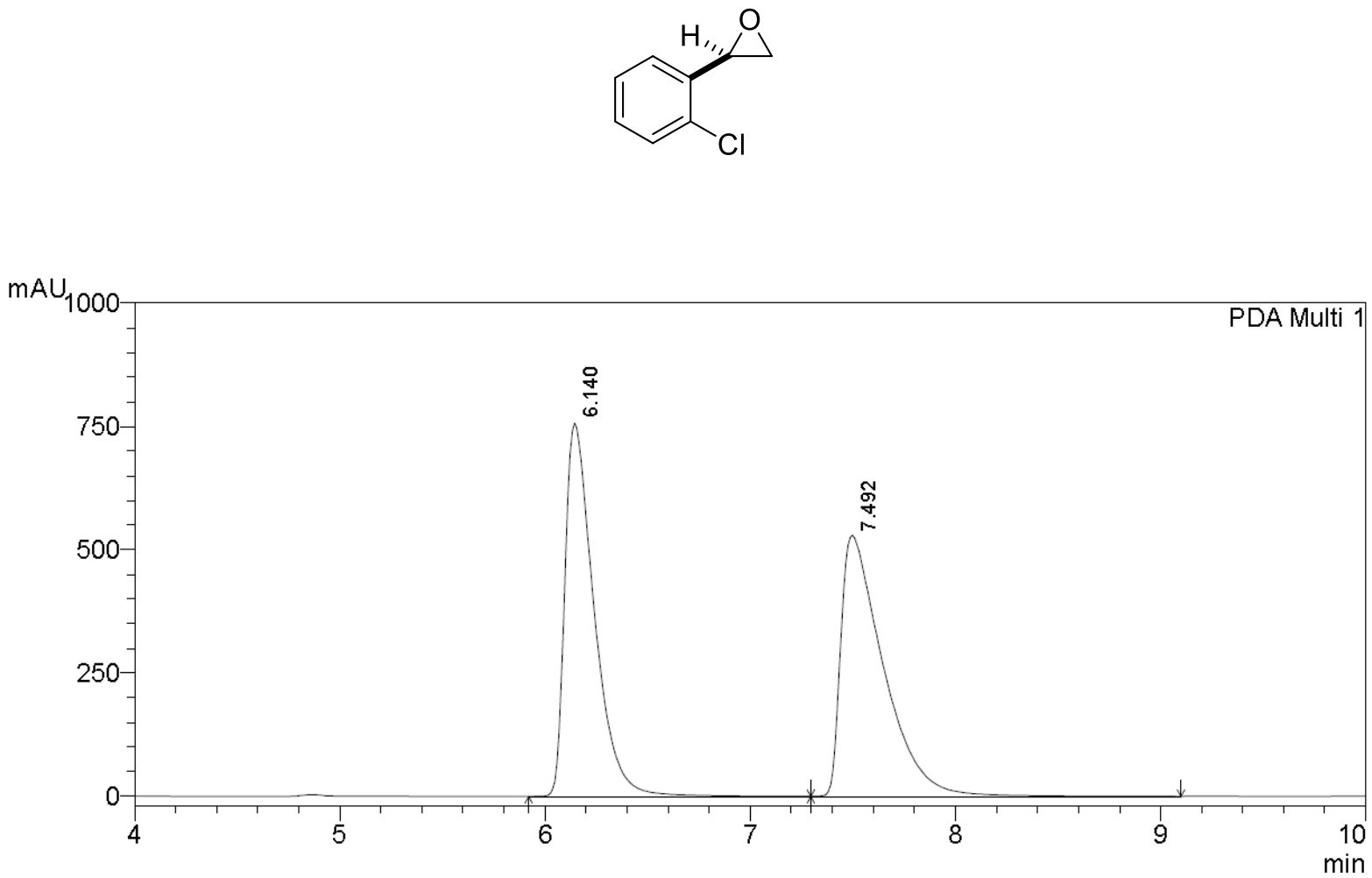

1 PDA Multi $1 / 205 \mathrm{~nm} 4 \mathrm{~nm}$

PeakTable

PDA Ch1 $205 \mathrm{~nm} 4 \mathrm{~nm}$
\begin{tabular}{|r|r|r|r|}
\hline Peak\# & Ret. Time & \multicolumn{1}{|c|}{ Area } & Area $\%$ \\
\hline 1 & 6.140 & 7505599 & 49.673 \\
\hline 2 & 7.492 & 7604353 & 50.327 \\
\hline Total & & 15109952 & 100.000 \\
\hline
\end{tabular}

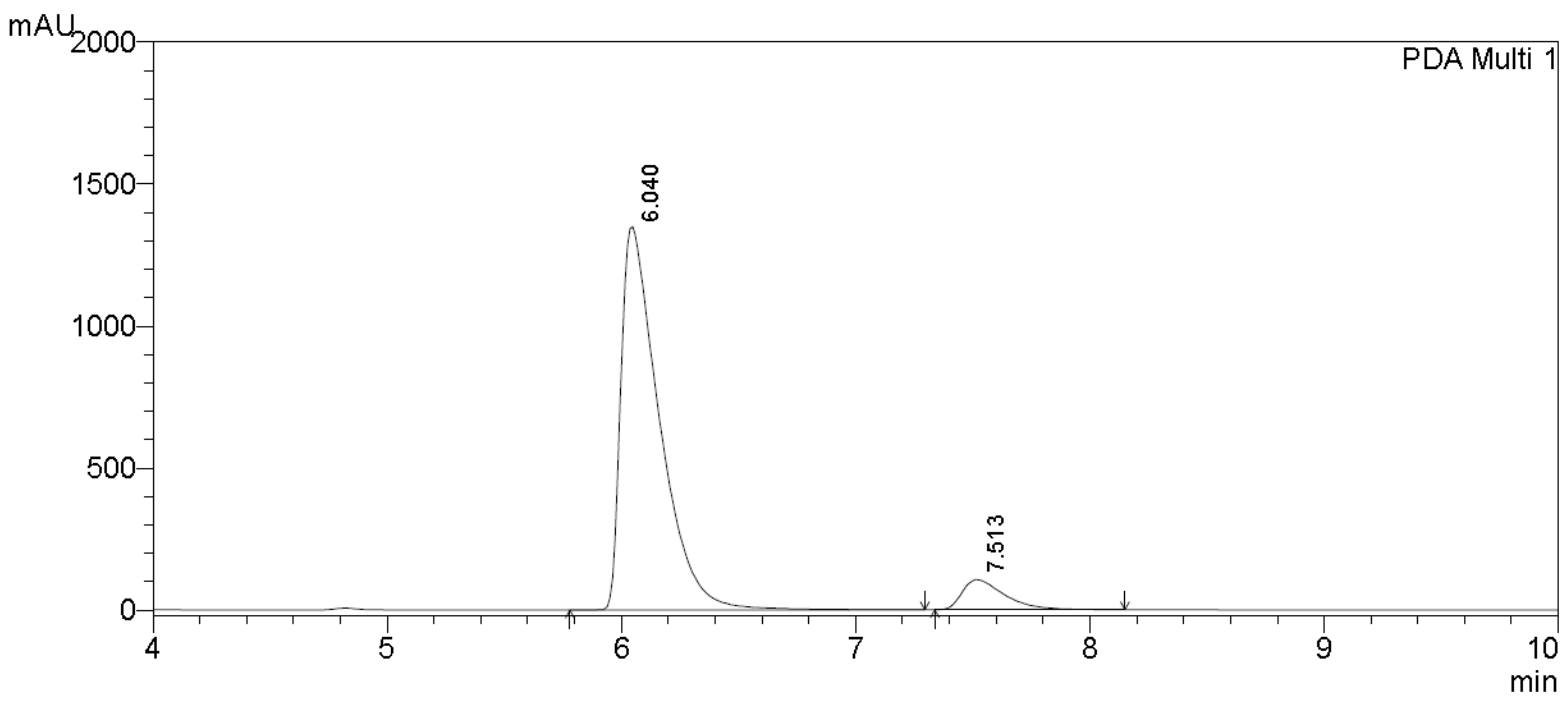

1 PDA Multi 1/205nm 4nm

PeakTable

PDA Ch1 $205 \mathrm{~nm} 4 \mathrm{~nm}$
\begin{tabular}{|r|r|r|r|}
\hline Peak\# & Ret. Time & \multicolumn{1}{|c|}{ Area } & Area $\%$ \\
\hline 1 & 6.040 & 15369779 & 92.031 \\
\hline 2 & 7.513 & 1330813 & 7.969 \\
\hline Total & & 16700592 & 100.000 \\
\hline
\end{tabular}


<smiles>Clc1ccccc1[C@H]1CS1</smiles>

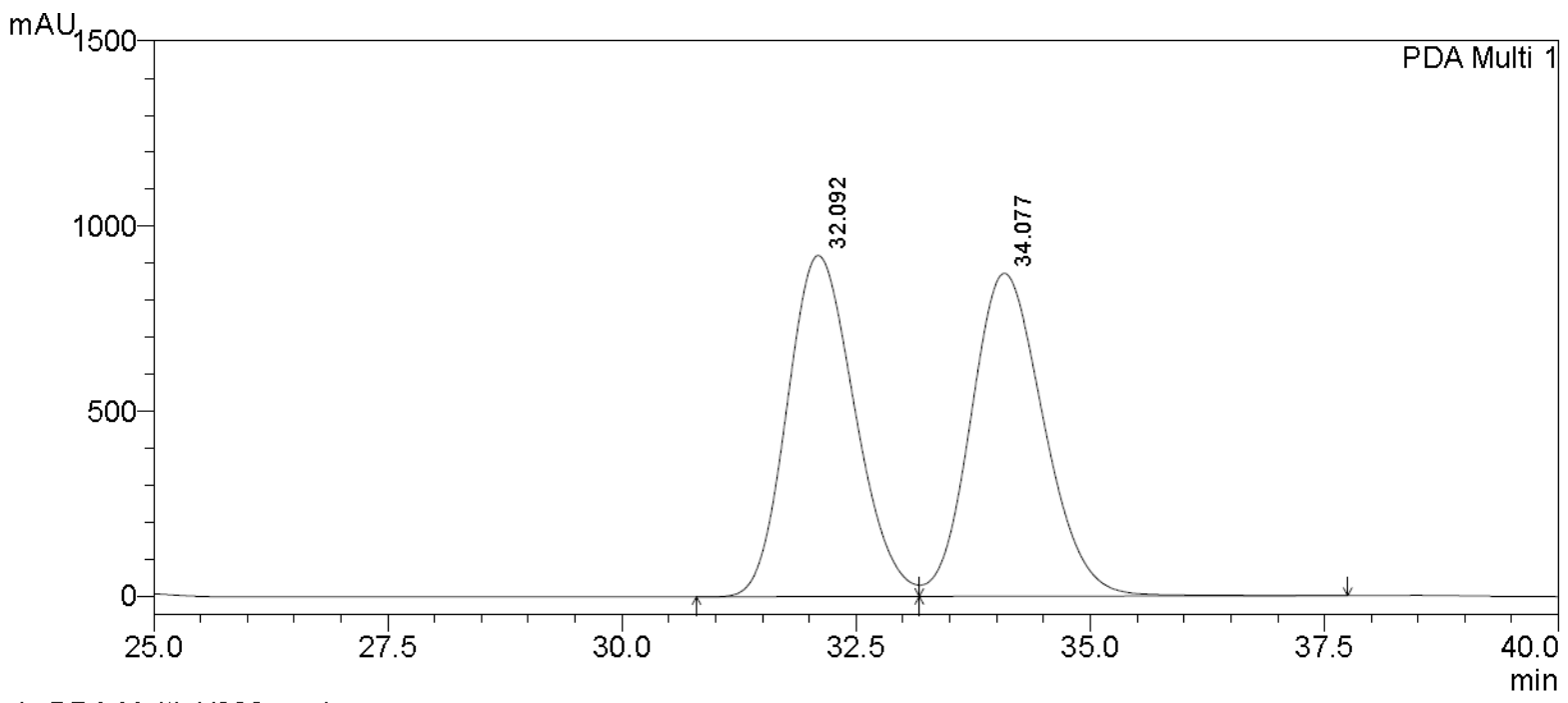

1 PDA Multi $1 / 220 \mathrm{~nm} 4 \mathrm{~nm}$

PeakTable

PDA Ch1 220nm 4nm

\begin{tabular}{|r|r|r|r|}
\hline Peak\# & Ret. Time & Area & Area \% \\
\hline 1 & 32.092 & 46233061 & 49.447 \\
\hline 2 & 34.077 & 47266928 & 50.553 \\
\hline Total & & 93499989 & 100.000 \\
\hline
\end{tabular}

mAU

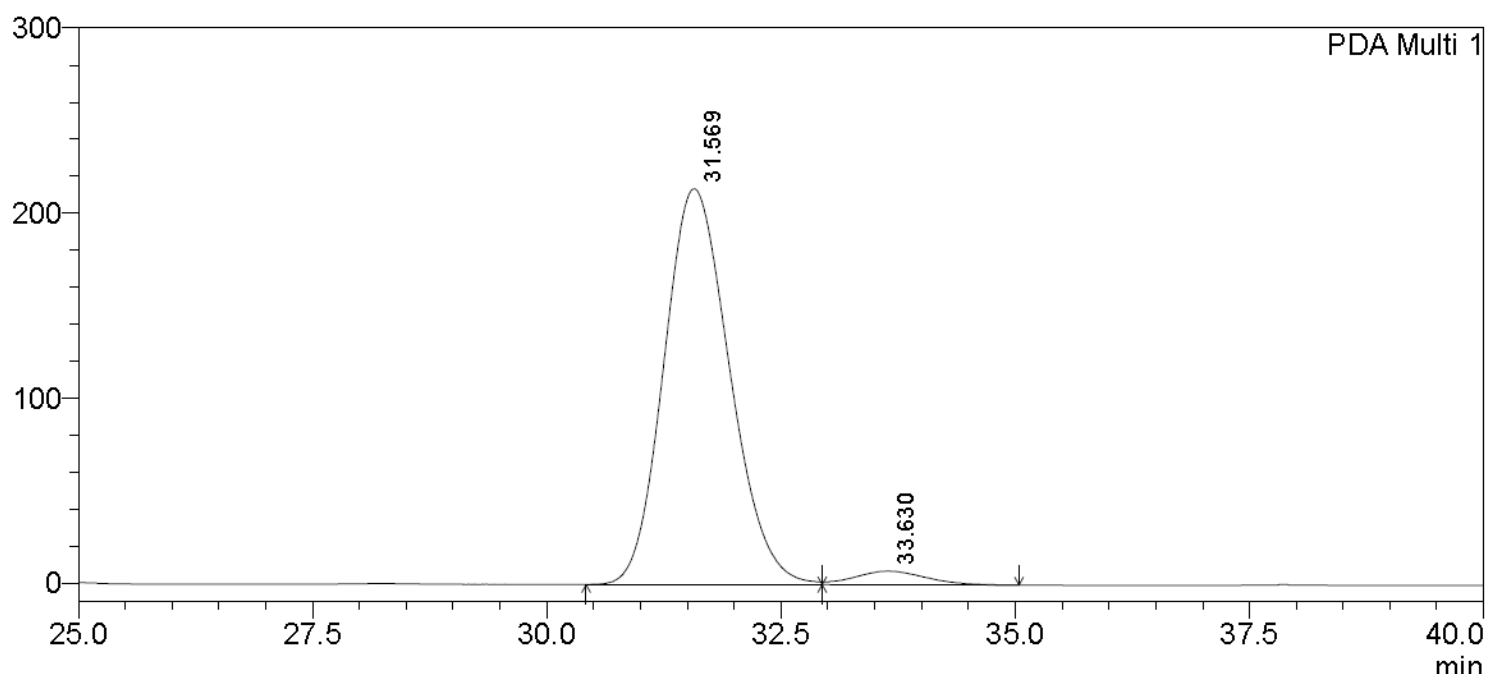

1 PDA Multi 1/220nm 4nm

PeakTable

PDA Ch1 220nm 4nm

\begin{tabular}{|r|r|r|r|}
\hline \multicolumn{1}{|c|}{ Peak\# } & Ret. Time & \multicolumn{1}{c|}{ Area } & \multicolumn{1}{c|}{ Area \% } \\
\hline 1 & 31.569 & 10466171 & 96.391 \\
\hline 2 & 33.630 & 391876 & 3.609 \\
\hline Total & & 10858047 & 100.000 \\
\hline
\end{tabular}



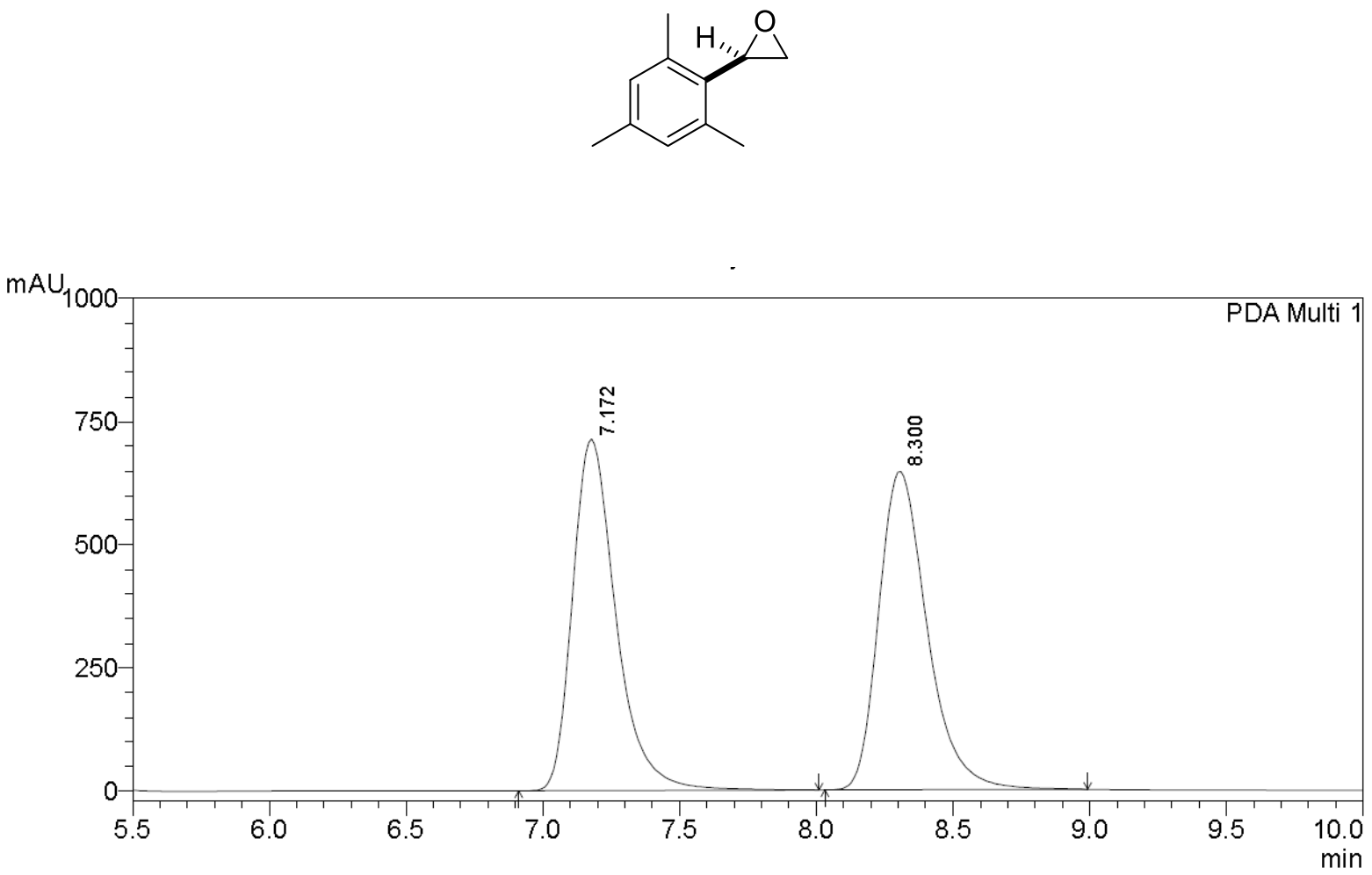

1 PDA Multi $1 / 205 \mathrm{~nm} 4 \mathrm{~nm}$

PeakTable

PDA Ch1 $205 \mathrm{~nm} 4 \mathrm{~nm}$
\begin{tabular}{|r|r|r|r|}
\hline Peak\# & Ret. Time & \multicolumn{1}{|c|}{ Area } & Area $\%$ \\
\hline 1 & 7.172 & 7861002 & 49.713 \\
\hline 2 & 8.300 & 7951614 & 50.287 \\
\hline Total & & 15812616 & 100.000 \\
\hline
\end{tabular}

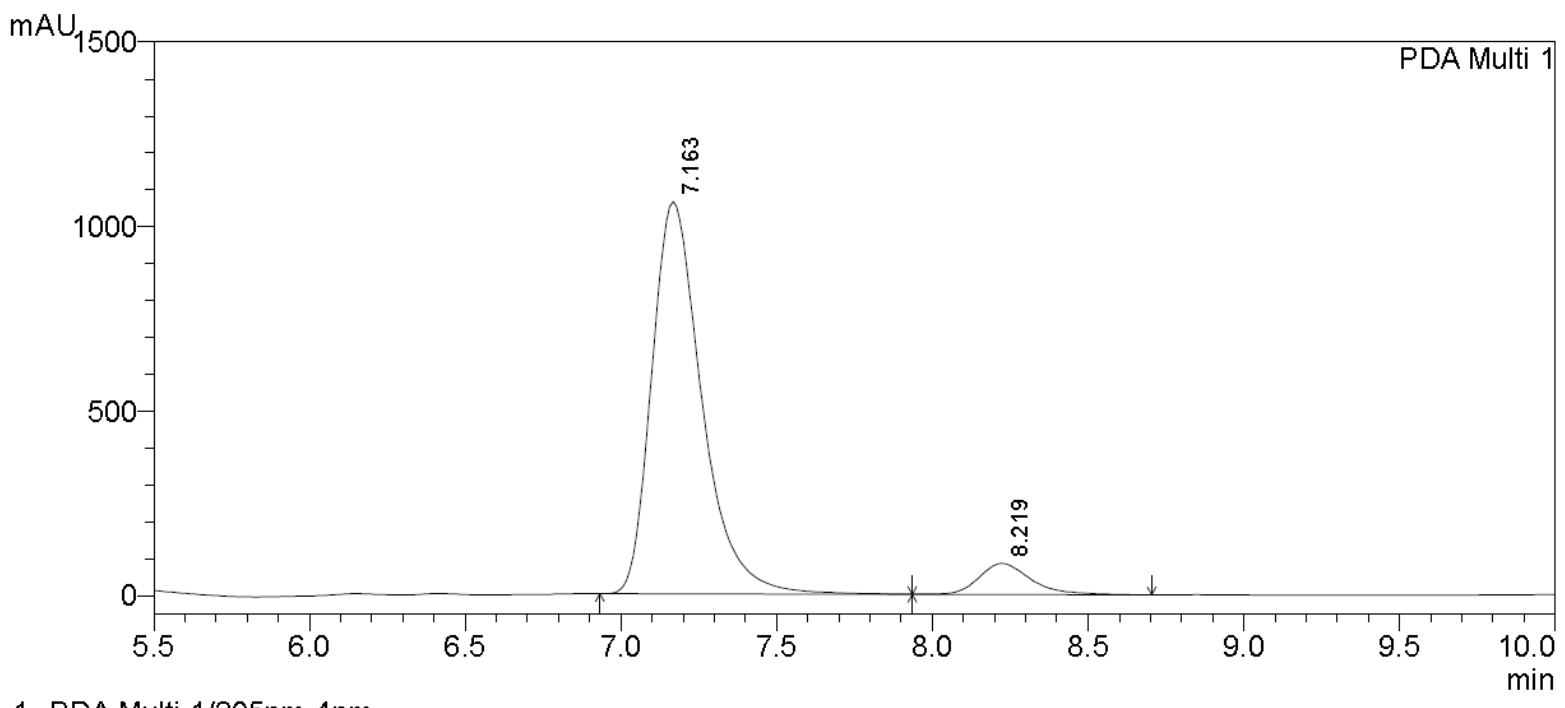

1 PDA Multi 1/205nm 4nm

PeakTable

PDA Ch1 205nm 4nm

\begin{tabular}{|r|r|r|r|}
\hline \multicolumn{1}{|c|}{ Peak\# } & \multicolumn{1}{|c|}{ Ret. Time } & \multicolumn{1}{|c|}{ Area } & \multicolumn{1}{|c|}{ Area \% } \\
\hline 1 & 7.163 & 11887763 & 92.405 \\
\hline 2 & 8.219 & 977112 & 7.595 \\
\hline Total & & 12864875 & 100.000 \\
\hline
\end{tabular}


<smiles>Cc1cc(C)c([C@H]2CS2)c(C)c1</smiles>

MAU

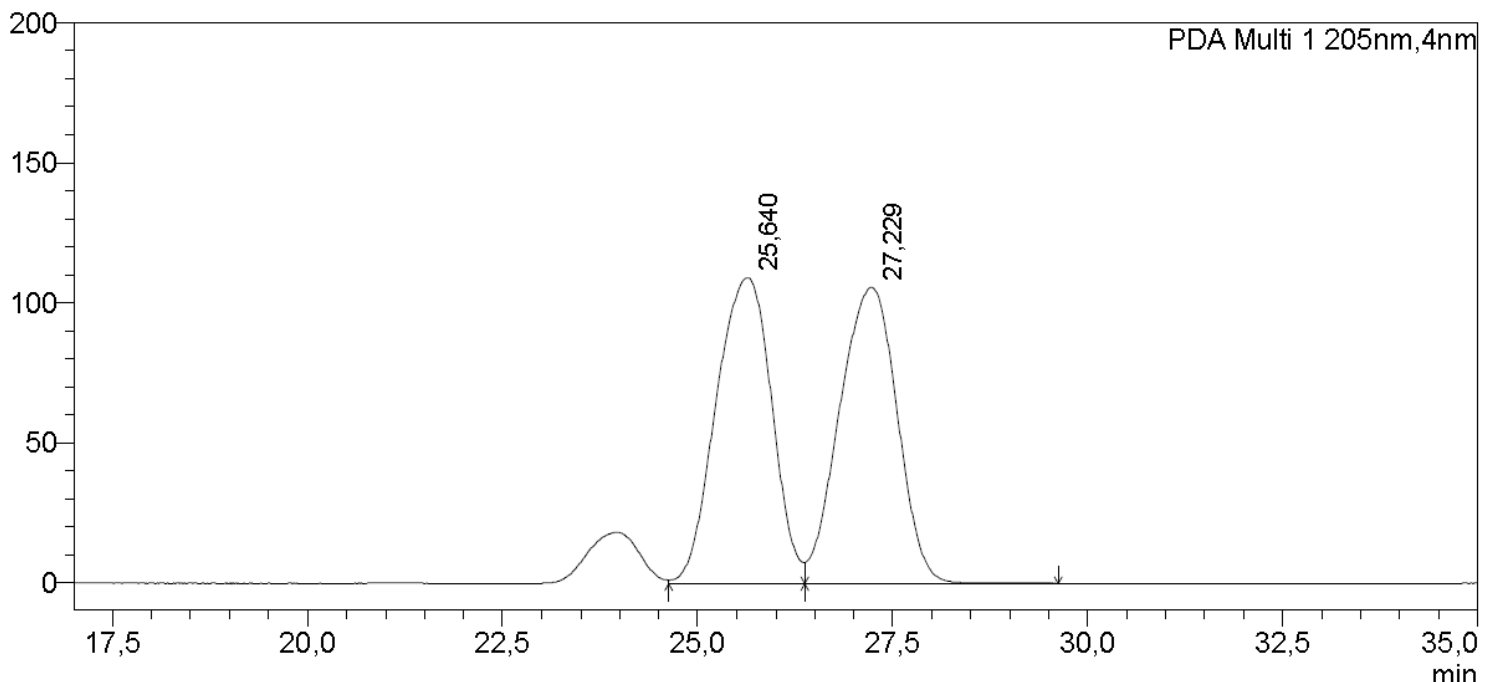

<Peak Table>

PDA Ch1 205nm

\begin{tabular}{|r|r|r|r|r|}
\hline Peak\# Ret. Time & \multicolumn{1}{c|}{ Area } & Height & \multicolumn{1}{c|}{ Area\% } \\
\hline 1 & 25,640 & 5453863 & 109541 & 49,956 \\
\hline 2 & 27,229 & 5463444 & 106055 & 50,044 \\
\hline Total & & 10917307 & 215596 & 100,000 \\
\hline
\end{tabular}

mAU

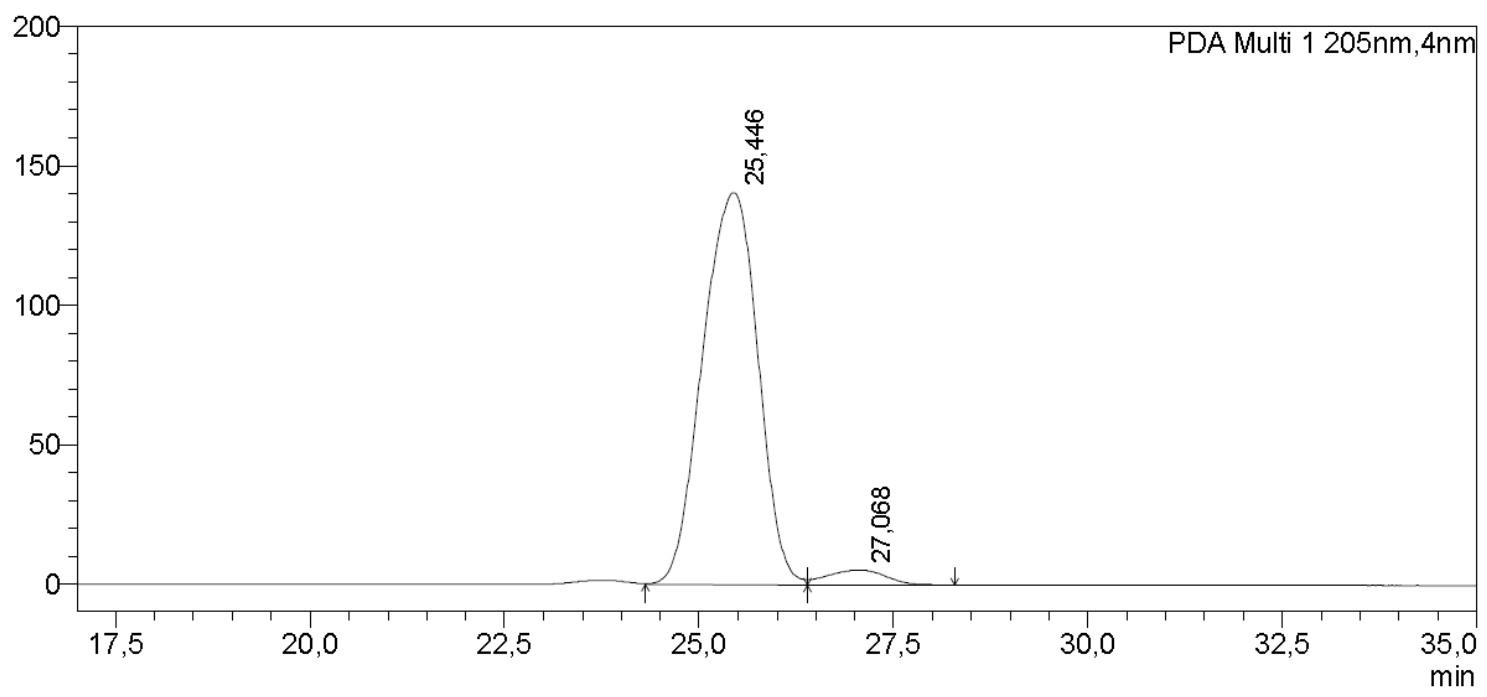

<Peak Table>

PDA Ch1 205nm

\begin{tabular}{|r|r|r|r|r|}
\hline Peak\# & Ret. Time & \multicolumn{1}{|c|}{ Area } & Height & \multicolumn{1}{c|}{ Area\% } \\
\hline 1 & 25,446 & 6966196 & 140657 & 96,173 \\
\hline 2 & 27,068 & 277171 & 5291 & 3,827 \\
\hline Total & & 7243367 & 145947 & 100,000 \\
\hline
\end{tabular}




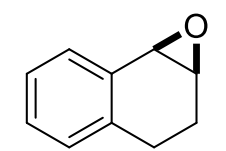

mAU

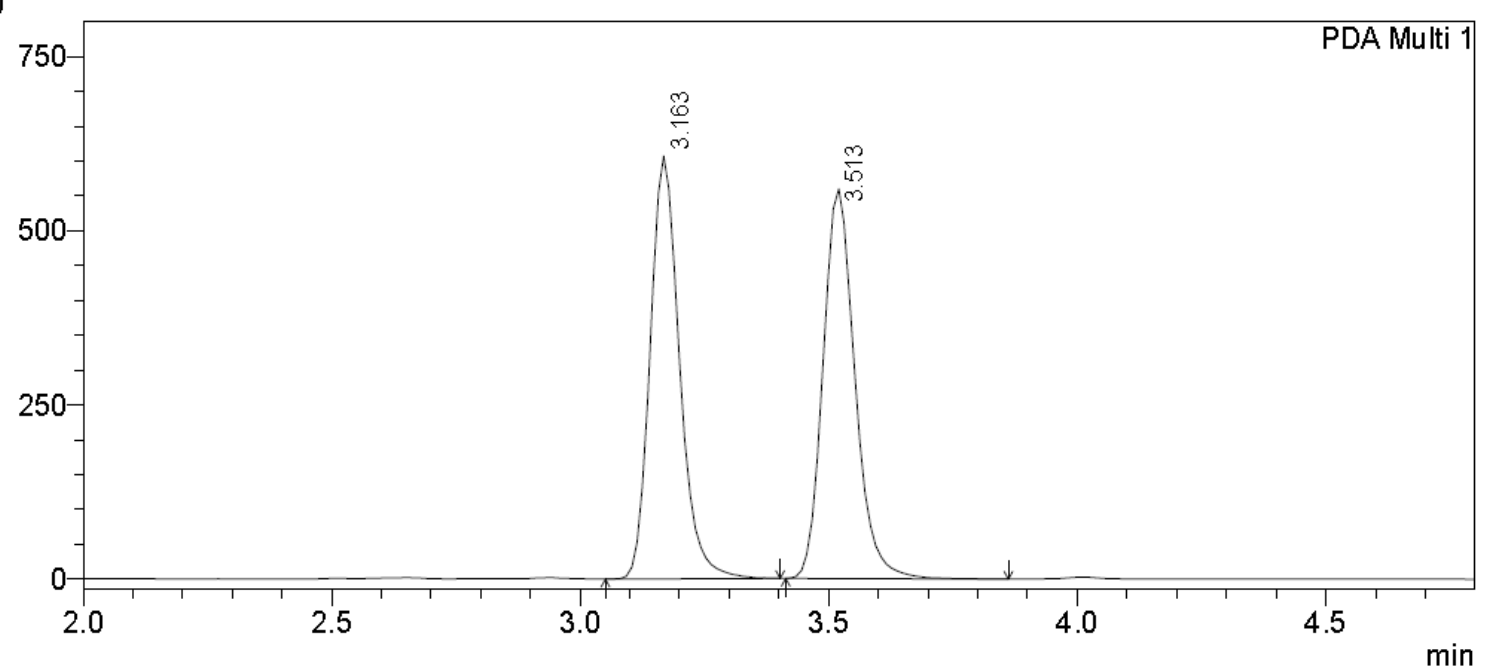

1 PDA Multi 1/205nm 4nm

PeakTable

PDA Ch1 205nm 4nm

\begin{tabular}{|r|r|r|r|}
\hline \multicolumn{1}{|c|}{ Peak\# } & Ret. Time & \multicolumn{1}{c|}{ Area } & \multicolumn{1}{c|}{ Area \% } \\
\hline 1 & 3.163 & 2500770 & 50.032 \\
\hline 2 & 3.513 & 2497566 & 49.968 \\
\hline Total & & 4998337 & 100.000 \\
\hline
\end{tabular}

mAU

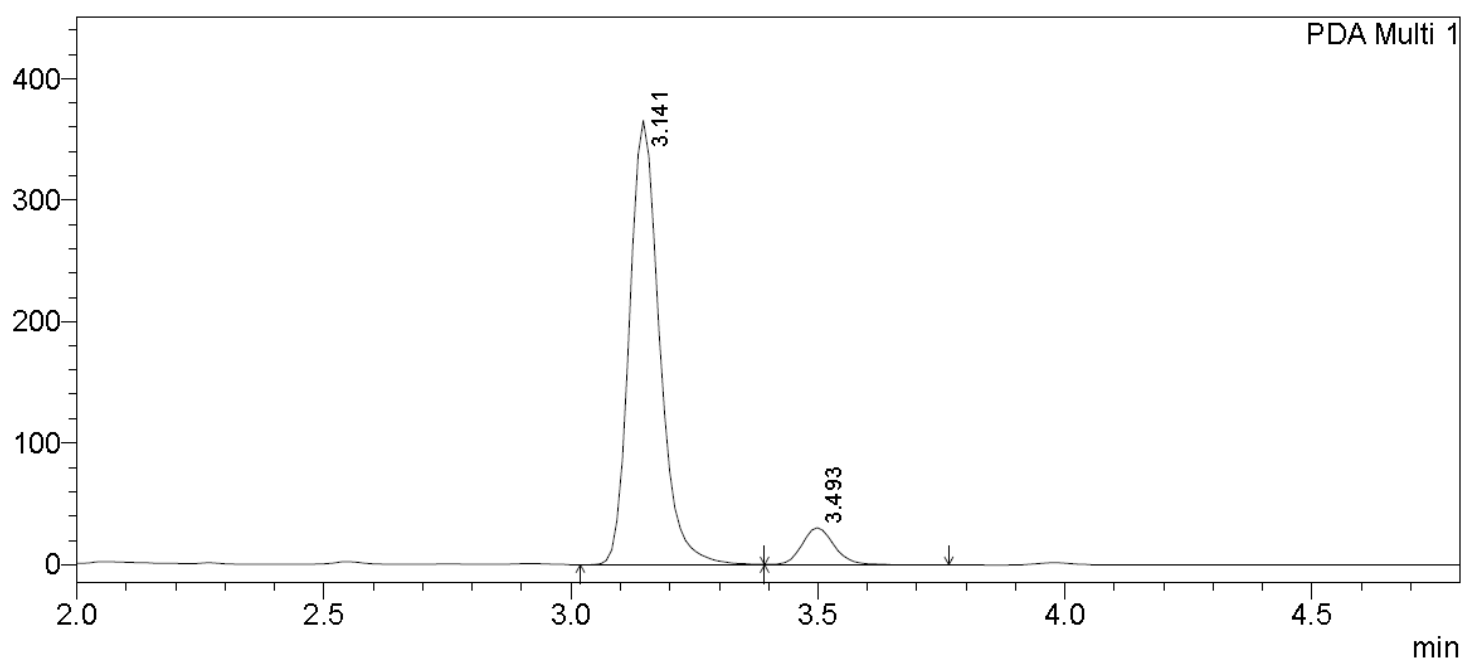

1 PDA Multi 1/205nm 4nm

PeakTable

PDA Ch1 $205 \mathrm{~nm}$ 4nm
\begin{tabular}{|r|r|r|r|}
\hline \multicolumn{1}{|c|}{ Peak\# } & Ret. Time & Area & \multicolumn{1}{|c|}{ Area $\%$} \\
\hline 1 & 3.141 & 1550371 & 91.765 \\
\hline 2 & 3.493 & 139138 & 8.235 \\
\hline Total & & 1689509 & 100.000 \\
\hline
\end{tabular}


<smiles>c1ccc2c(c1)CCC1SC21</smiles>
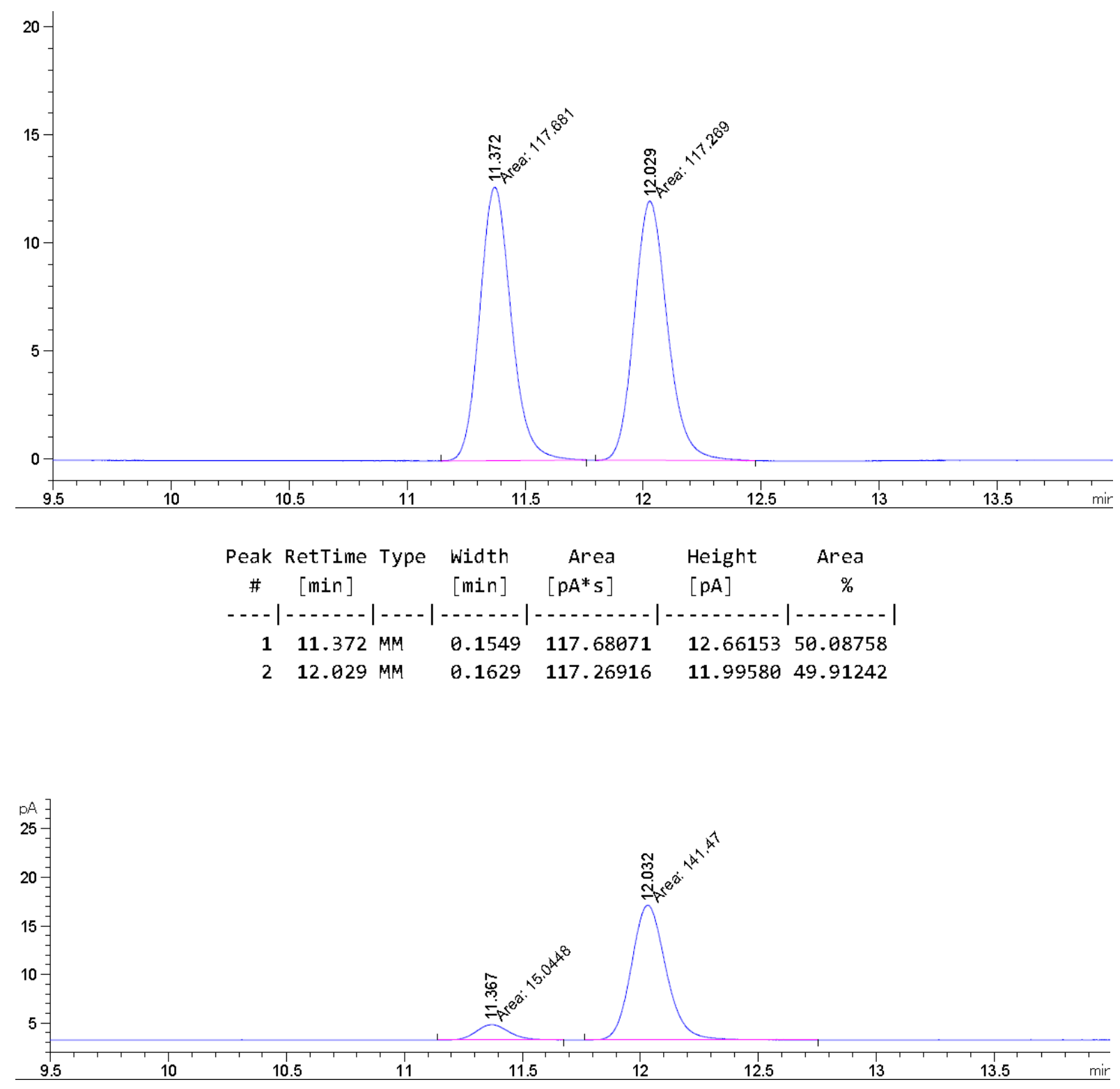

\begin{tabular}{|c|c|c|c|c|c|c|}
\hline $\begin{array}{c}\text { Peak } \\
\text { \# }\end{array}$ & $\begin{array}{c}\text { RetTime } \\
{[\mathrm{min}]}\end{array}$ & Type & $\begin{array}{l}\text { Width } \\
{[\text { min }]}\end{array}$ & $\begin{array}{r}\text { Area } \\
{\left[\mathrm{pA}^{*} \mathrm{~s}\right]}\end{array}$ & $\begin{array}{l}\text { Height } \\
{[p A]}\end{array}$ & $\begin{array}{c}\text { Area } \\
\%\end{array}$ \\
\hline & & & & & & ------ \\
\hline 1 & 11.367 & MM & 0.1597 & 15.04478 & 1.56973 & 9.61235 \\
\hline 2 & 12.032 & MM & 0.1703 & 141.47034 & 13.84243 & 90.38765 \\
\hline
\end{tabular}


<smiles>C1CCC([C@H]2CO2)CC1</smiles>

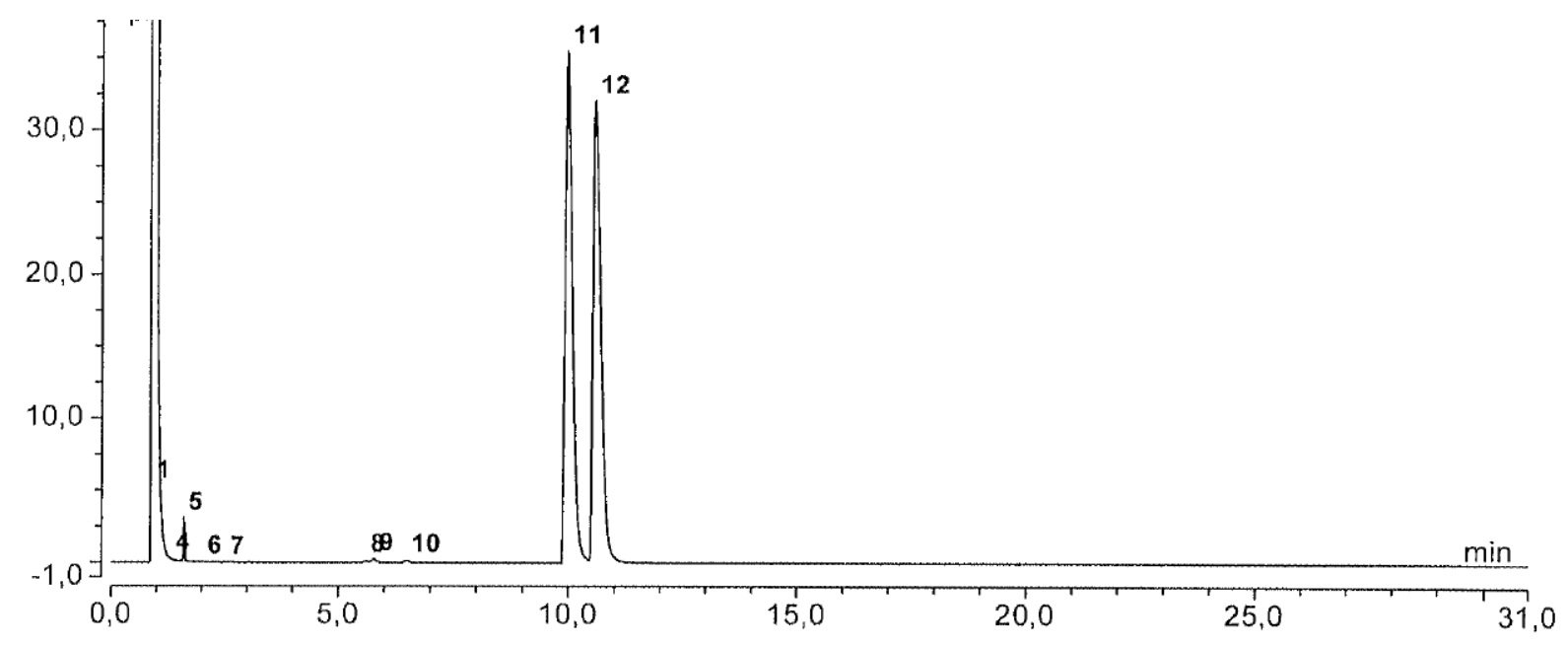

$\begin{array}{rrr}\text { No. } & \text { Ret.Time } & \text { Rel.Area } \\ & \text { min } & \% \\ 11 & 9,96 & 49,81 \\ 12 & 10,56 & 50,19\end{array}$

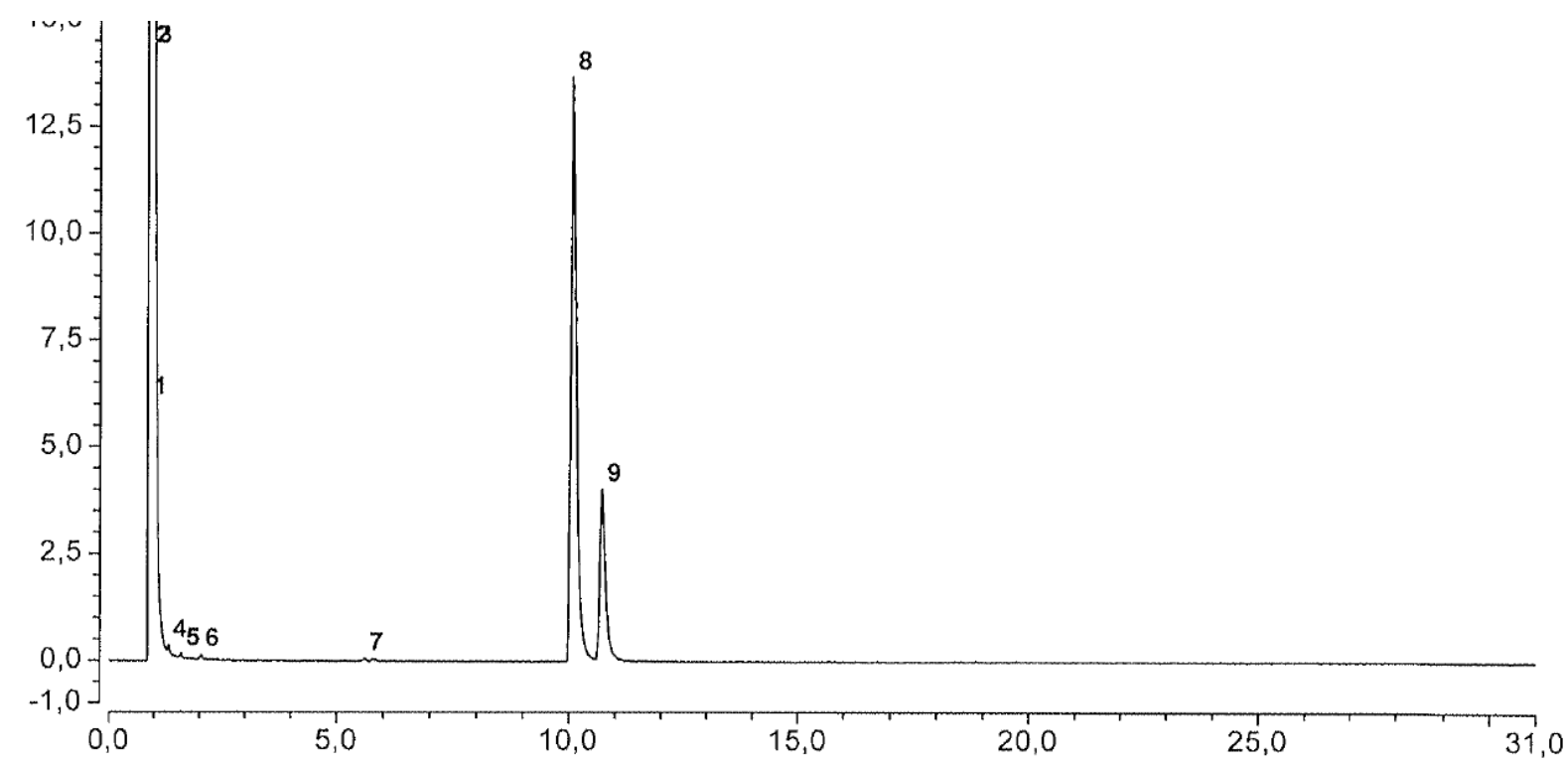

$\begin{array}{rrr}\text { No. } & \text { Ret.Time } & \text { Rel.Area } \\ & \text { min } & \% \\ 8 & 10,08 & 77,01 \\ 9 & 10,72 & 22,99\end{array}$


<smiles>C1CCC([C@H]2CS2)CC1</smiles>

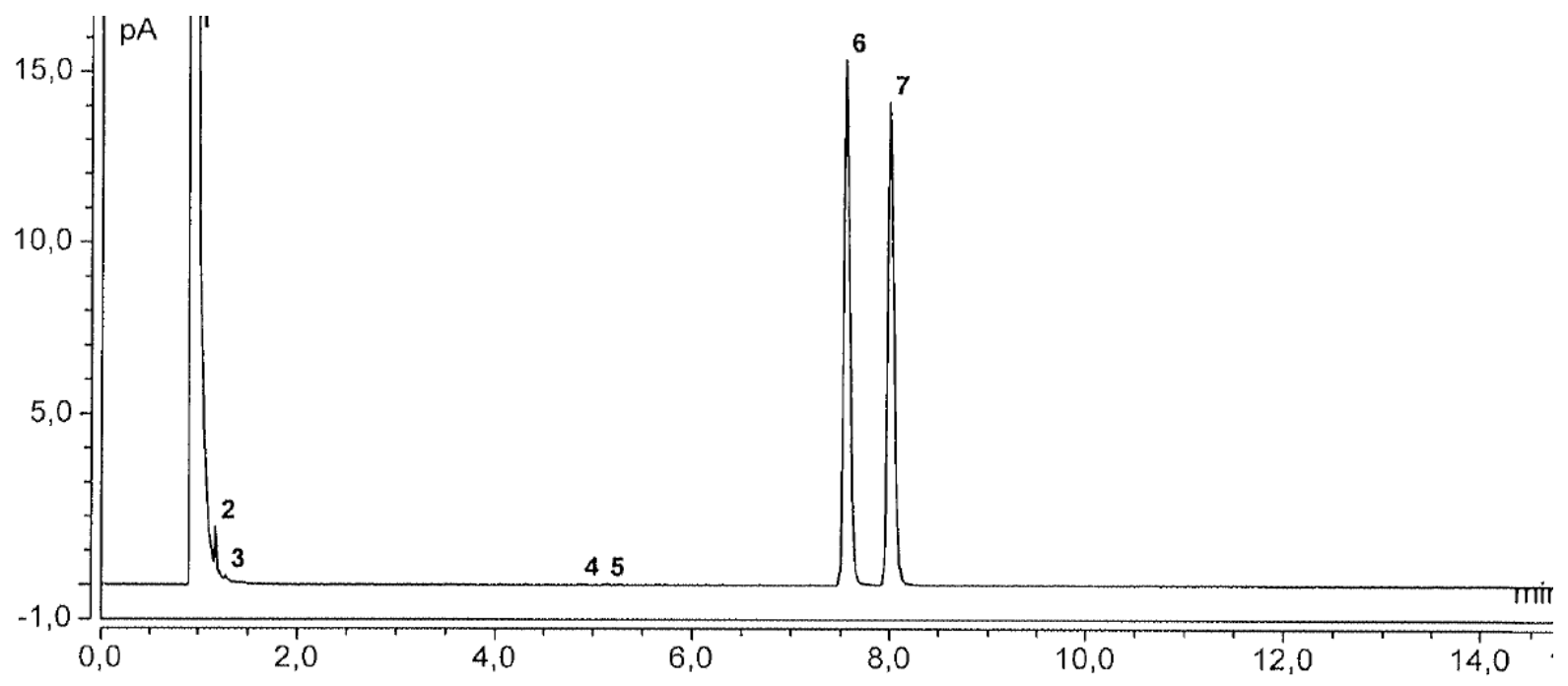

$\begin{array}{rrr}\text { No. } & \text { Ret.Time } & \text { Rel.Area } \\ & \text { min } & \% \\ 6 & 7,55 & 50,13 \\ 7 & 8,00 & 49,87\end{array}$

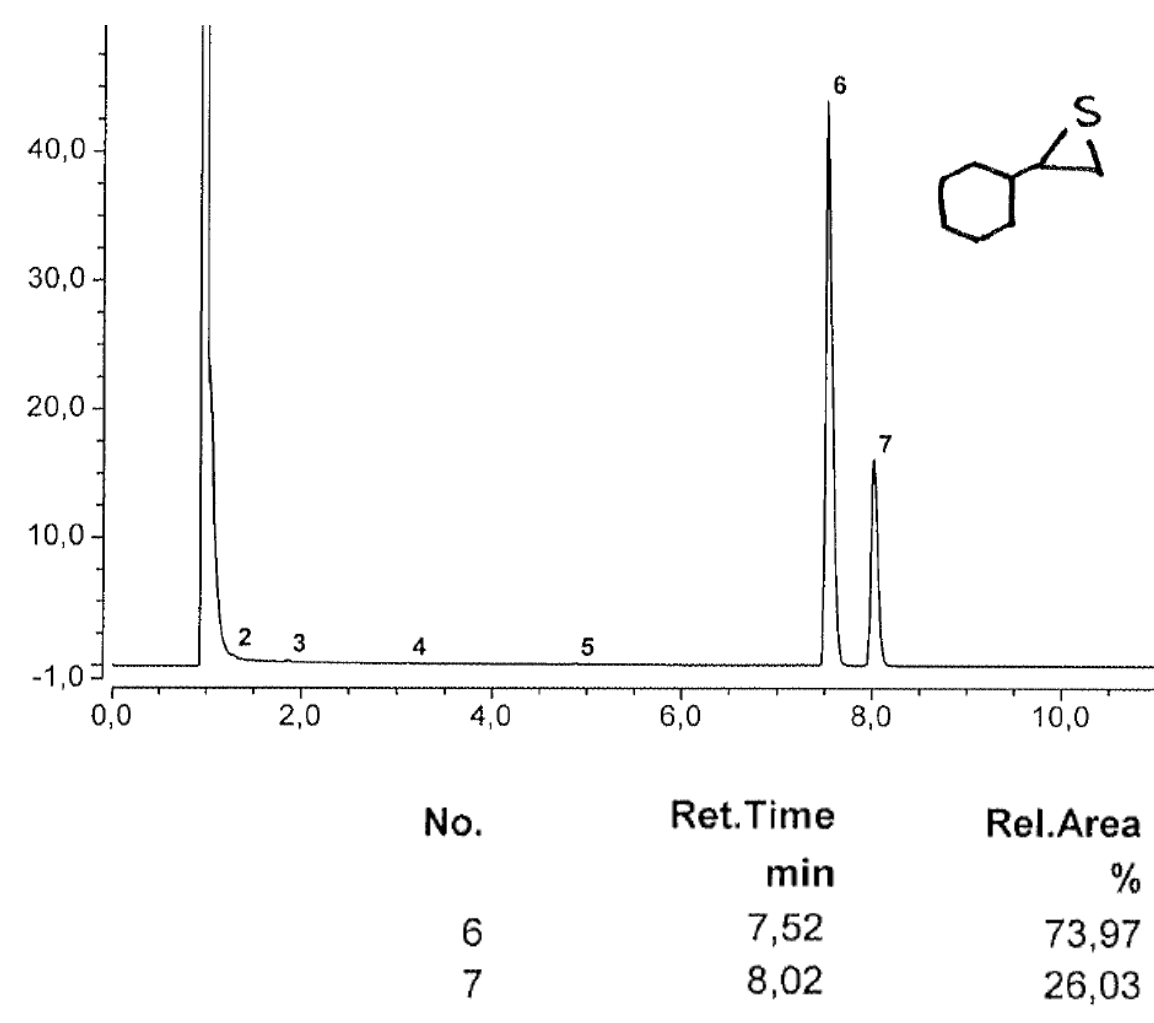



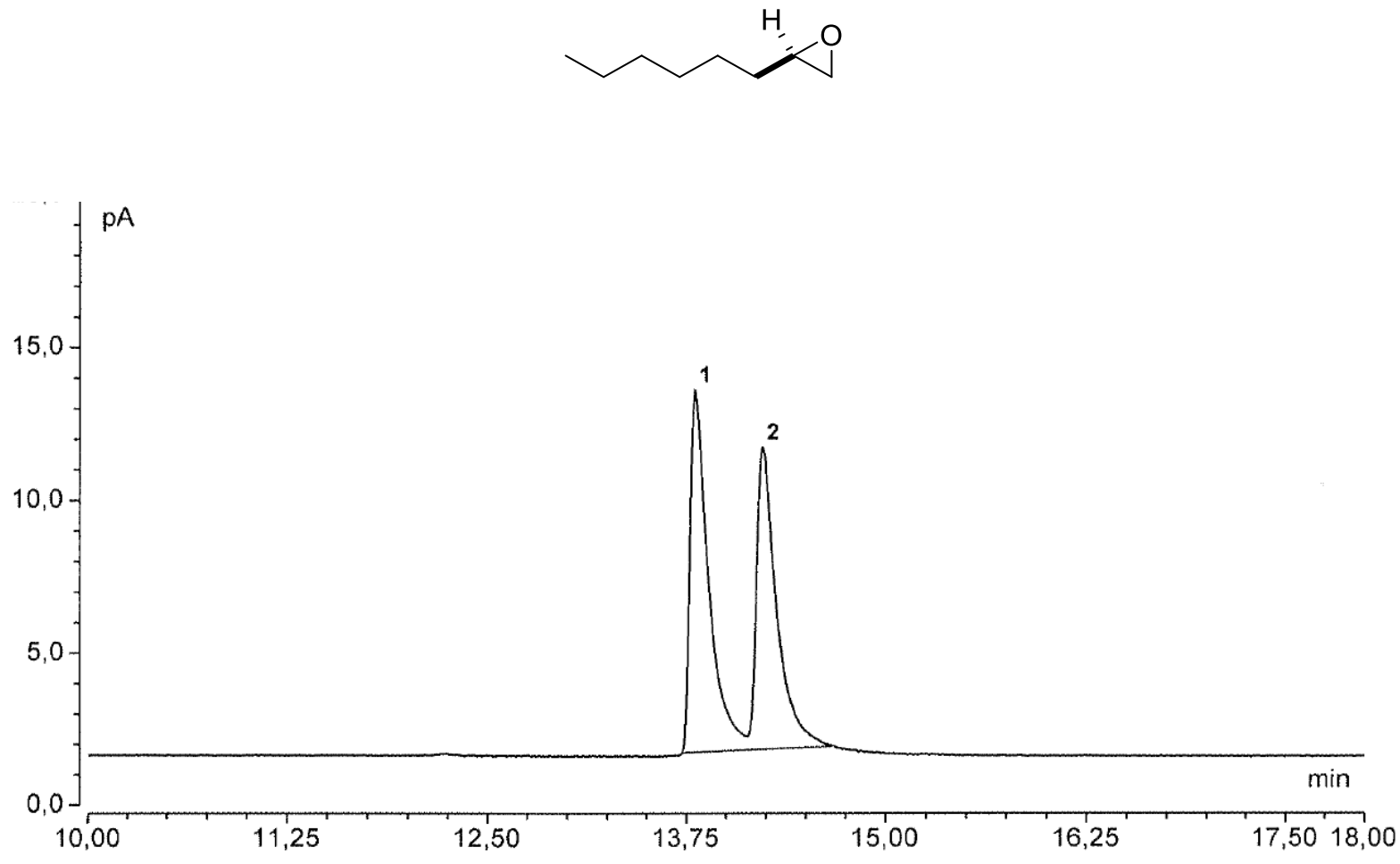

No.

Ret.Time area- $\%$

$\min \%$

$1 \quad 13,81 \quad 52,46$

$2 \quad 14,23 \quad 47,54$

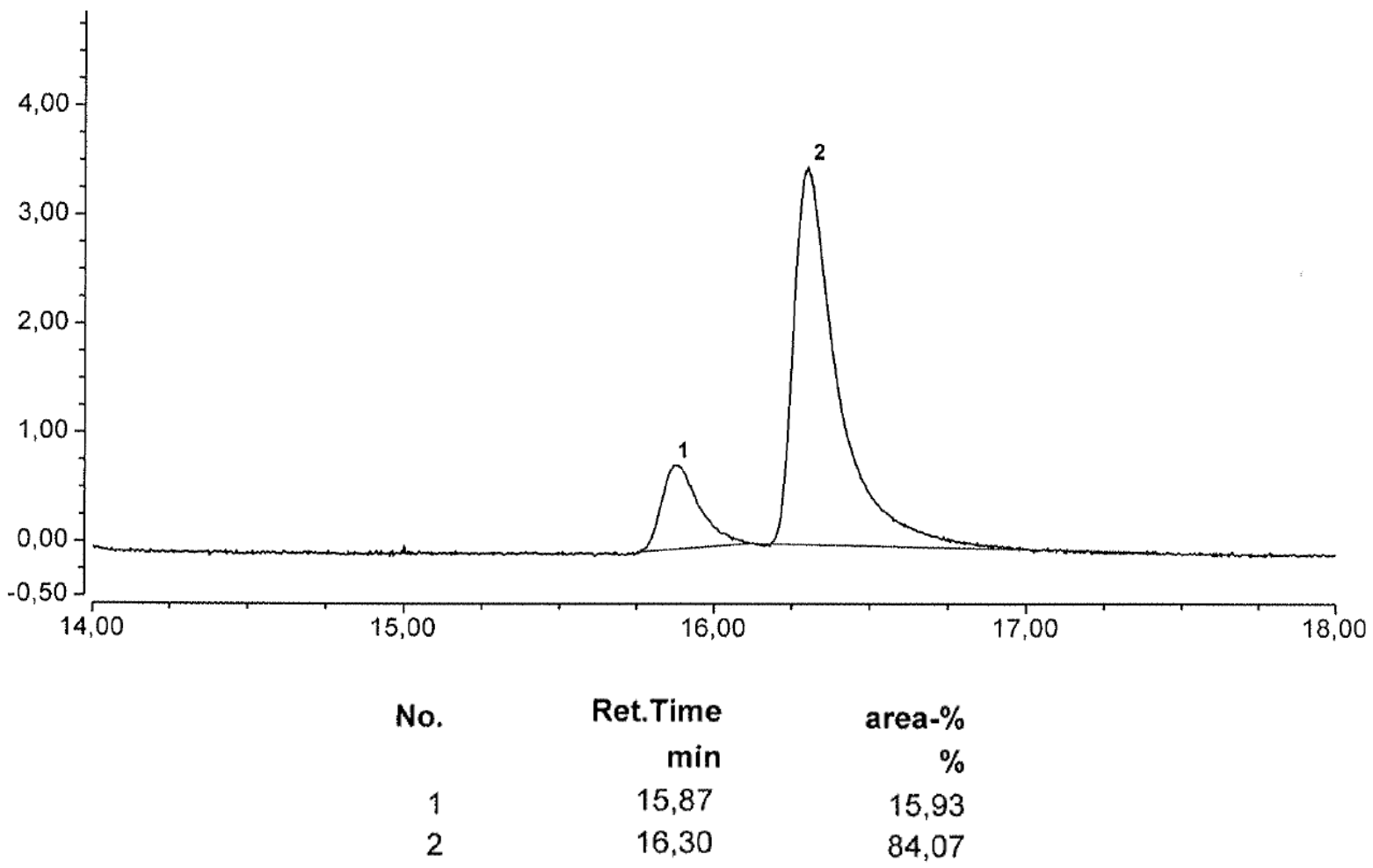



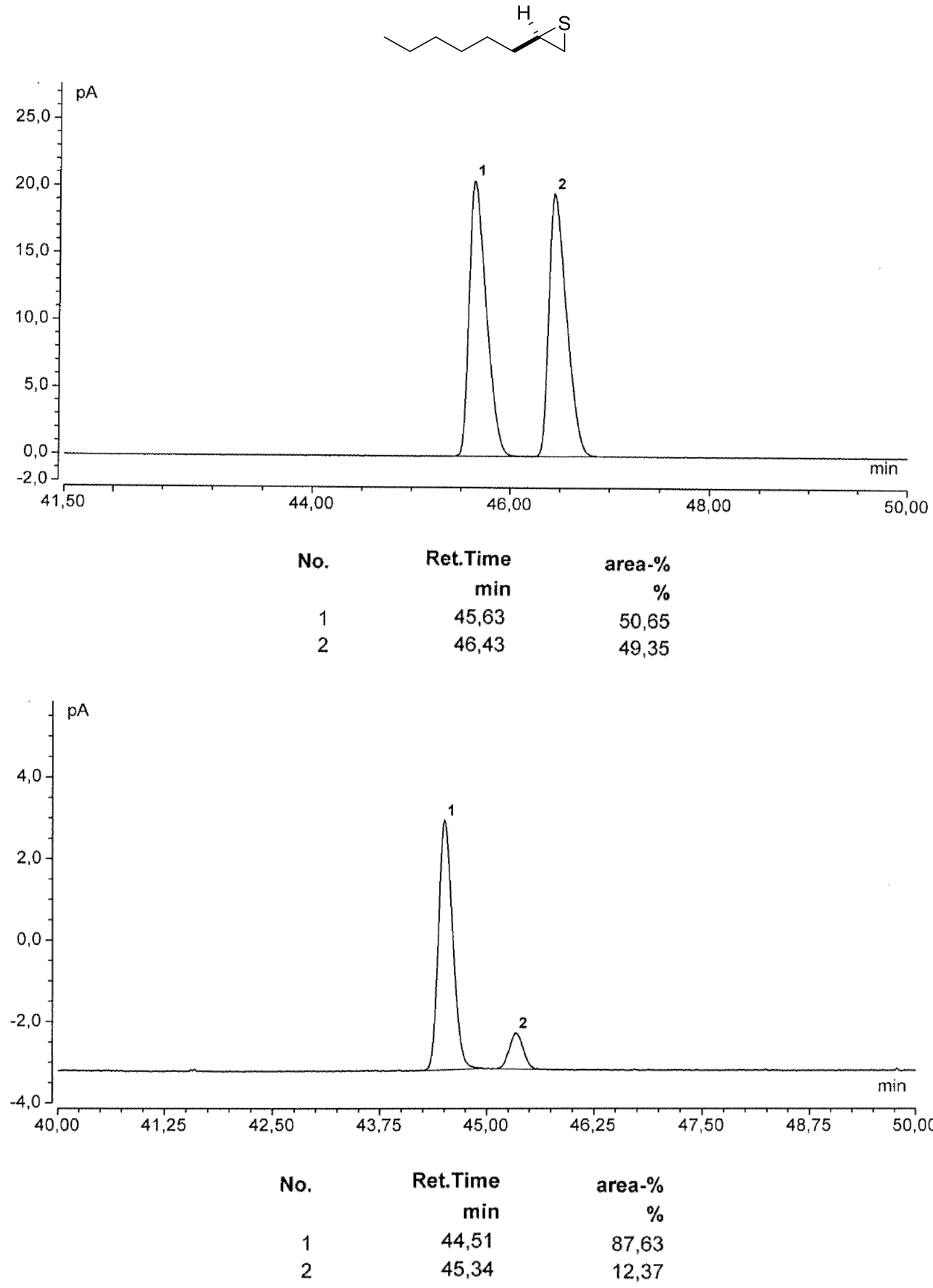

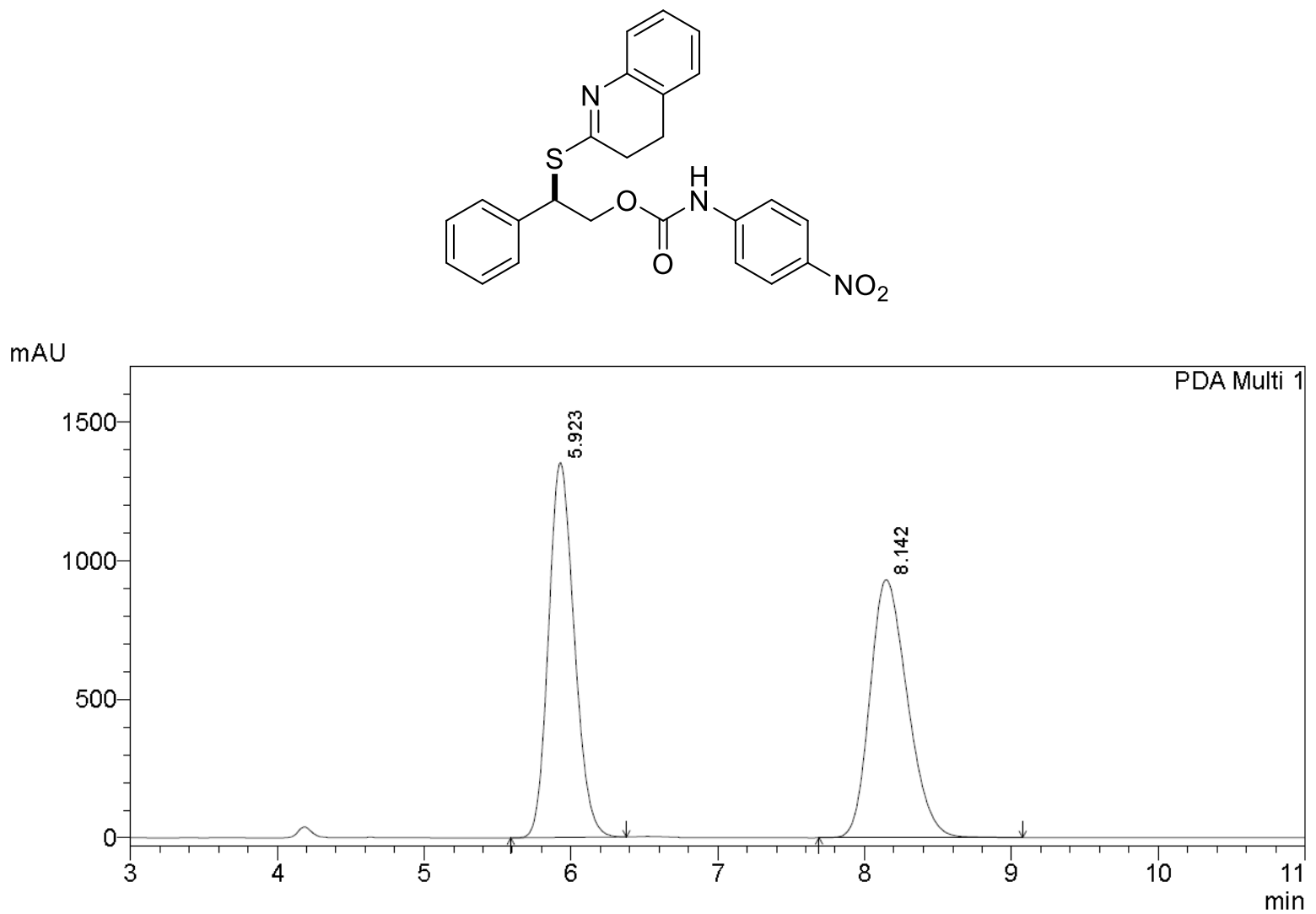

1 PDA Multi 1/254nm 4nm

PDA Ch1 254nm 4nm

PeakTable

\begin{tabular}{|r|r|r|r|}
\hline \multicolumn{1}{|c|}{ Peak\# } & Ret. Time & Area & \multicolumn{1}{c|}{ Area \% } \\
\hline 1 & 5.923 & 16500107 & 49.958 \\
\hline 2 & 8.142 & 16527890 & 50.042 \\
\hline Total & & 33027998 & 100.000 \\
\hline
\end{tabular}

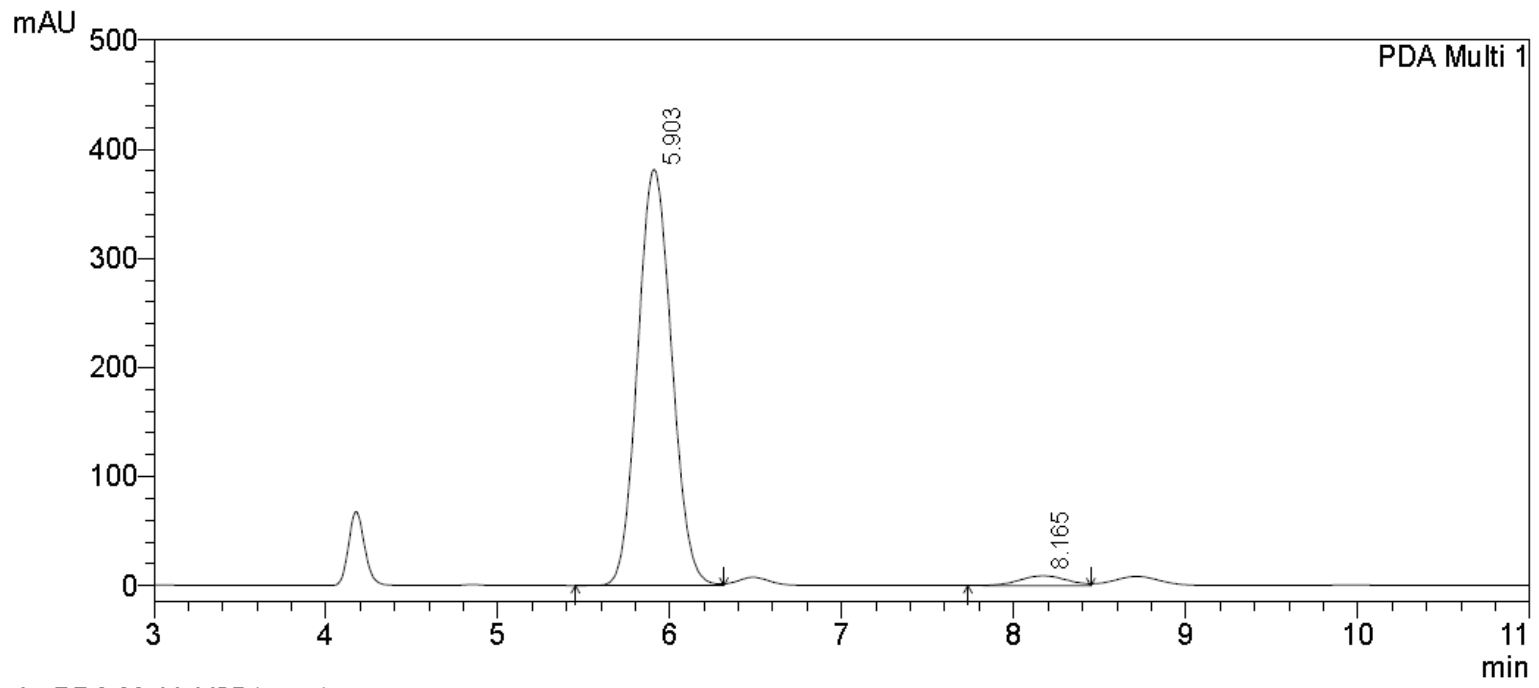

1 PDA Multi $1 / 254 \mathrm{~nm} 4 \mathrm{~nm}$

PeakTable

PDA Ch1 254nm 4nm

\begin{tabular}{|r|r|r|r|}
\hline \multicolumn{1}{|c|}{ Peak\# } & \multicolumn{1}{|c|}{ Ret. Time } & \multicolumn{1}{c|}{ Area } & \multicolumn{1}{c|}{ Area \% } \\
\hline 1 & 5.903 & 5254910 & 96.770 \\
\hline 2 & 8.165 & 175375 & 3.230 \\
\hline Total & & 5430286 & 100.000 \\
\hline
\end{tabular}

